\title{
Evaluation of Lower East Fork Poplar Creek Mercury Sources
}
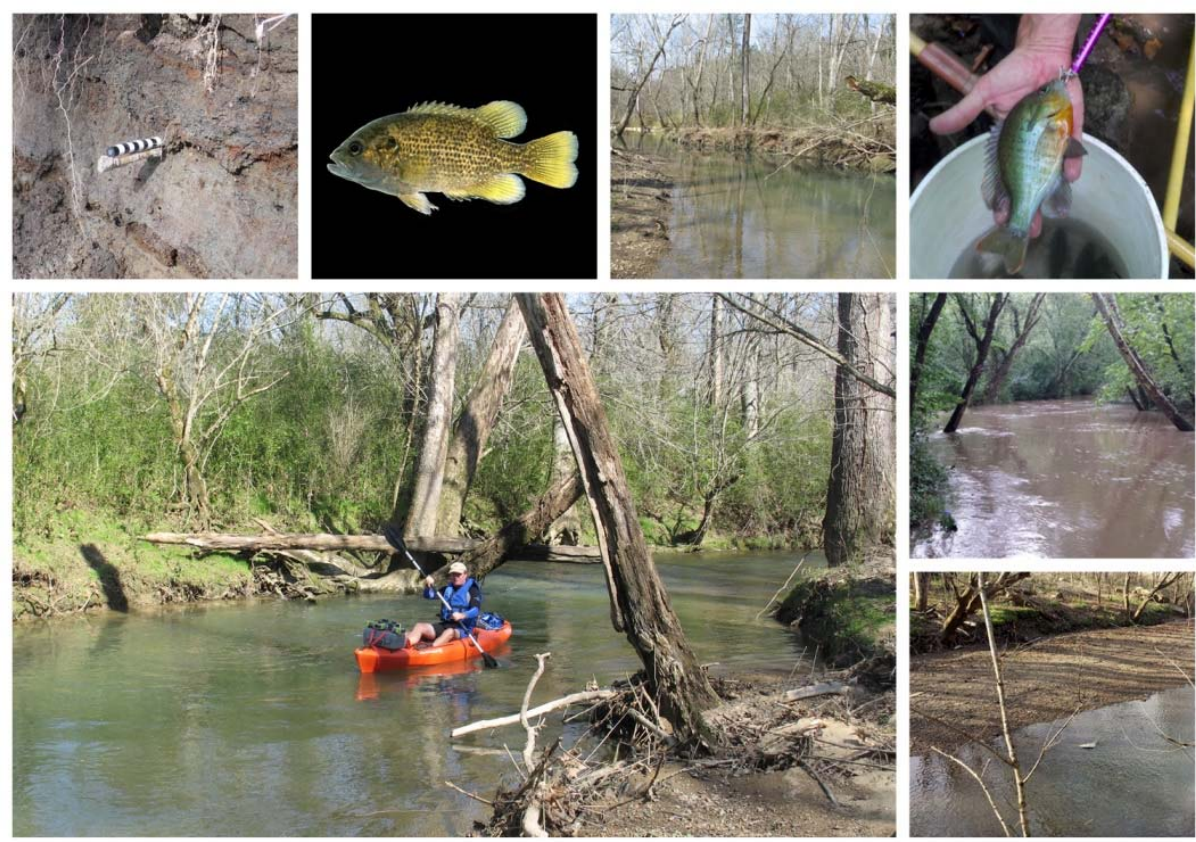

Approved for public release.

Distribution is unlimited.

David Watson

Scott Brooks

Teresa Mathews

Mark Bevelhimer

Chris DeRolph

Craig Brandt

Mark Peterson

Richard Ketelle

June 2016 


\title{
DOCUMENT AVAILABILITY
}

Reports produced after January 1, 1996, are generally available free via US Department of Energy (DOE) SciTech Connect.

Website http://www.osti.gov/scitech/

Reports produced before January 1, 1996, may be purchased by members of the public from the following source:

\author{
National Technical Information Service \\ 5285 Port Royal Road \\ Springfield, VA 22161 \\ Telephone 703-605-6000 (1-800-553-6847) \\ TDD 703-487-4639 \\ Fax 703-605-6900 \\ E-mail info@ntis.gov \\ Website http://www.ntis.gov/help/ordermethods.aspx
}

Reports are available to DOE employees, DOE contractors, Energy Technology Data Exchange representatives, and International Nuclear Information System representatives from the following source:

Office of Scientific and Technical Information

PO Box 62

Oak Ridge, TN 37831

Telephone 865-576-8401

Fax 865-576-5728

E-mail reports@osti.gov

Website http://www.osti.gov/contact.html

This report was prepared as an account of work sponsored by an agency of the United States Government. Neither the United States Government nor any agency thereof, nor any of their employees, makes any warranty, express or implied, or assumes any legal liability or responsibility for the accuracy, completeness, or usefulness of any information, apparatus, product, or process disclosed, or represents that its use would not infringe privately owned rights. Reference herein to any specific commercial product, process, or service by trade name, trademark, manufacturer, or otherwise, does not necessarily constitute or imply its endorsement, recommendation, or favoring by the United States Government or any agency thereof. The views and opinions of authors expressed herein do not necessarily state or reflect those of the United States Government or any agency thereof. 
Environmental Sciences Division

\title{
EVALUATION OF LOWER EAST FORK POPLAR CREEK MERCURY SOURCES
}

\author{
David Watson \\ Scott Brooks \\ Teresa Mathews \\ Mark Bevelhimer \\ Chris DeRolph \\ Craig Brandt \\ Mark Peterson \\ Richard Ketelle
}

Date Published: June 2016

Prepared for

Lynn Sims, UCOR/RSI

Oak Ridge, TN 37831-7293

\author{
Prepared by \\ OAK RIDGE NATIONAL LABORATORY \\ Oak Ridge, TN 37831-6283 \\ managed by \\ UT-BATTELLE, LLC \\ for the \\ US DEPARTMENT OF ENERGY \\ under contract DE-AC05-00OR22725
}





\section{CONTENTS}

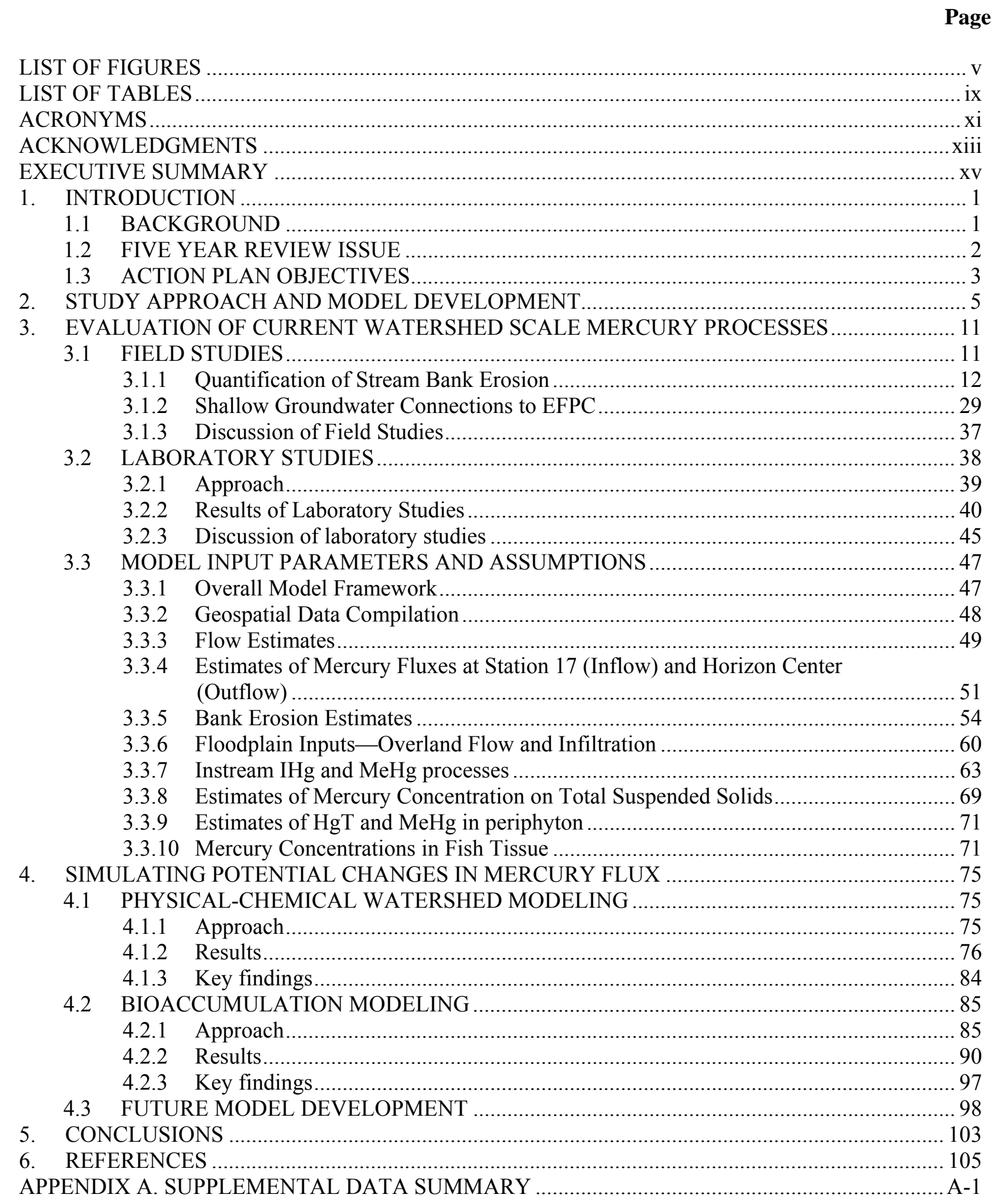





\section{LIST OF FIGURES}

Fig. 1. The East Fork Poplar Creek watershed.

Fig. 2. General project-level approach to address Action Plan 1's goal of providing a watershedscale understanding of the role of lower East Fork Poplar Creek (LEFPC) mercury sources.

Fig. 3. Conceptual model for understanding mercury source contributions to Lower East Fork Poplar Creek.

Fig. 4. Conceptual model for understanding floodplain and bank soil mercury flux to Lower East Fork Poplar Creek.

Fig. 5. Conceptual model for understanding instream mercury processes including bioaccumulation in Lower East Fork Poplar Creek. (Notes: TSS = total suspended solid;

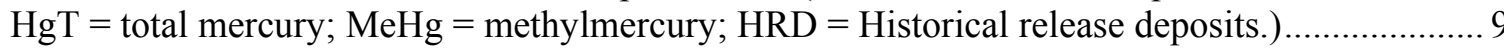

Fig. 6. Key EFPC monitoring locations and subwatershed boundaries................................................ 10

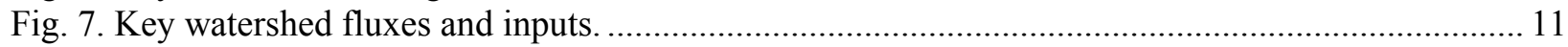

Fig. 8. Bank erosion hazard index (BEHI) values from analysis of the 2013 East Fork Poplar Creek stream bank video.

Fig. 9. Histogram of the bank erosion rate of the left and right banks from East Fork Poplar Creek kilometer 23 to the confluence with Poplar Creek

Fig. 10. Average bank erosion rate (BER) at $1 \mathrm{~km}$ intervals from East Fork Poplar Creek

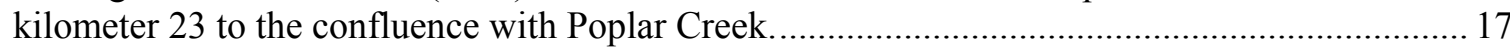

Fig. 11. BEHI values from the 2013 East Fork Poplar Creek stream bank video analysis........................ 18

Fig. 12. Histogram of bank erosion rates of the left and right banks from Outfall 200 to East Fork

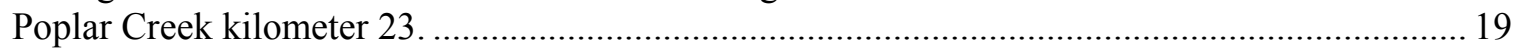

Fig. 13. Map of erosion pin sites on lower East Fork Poplar Creek. .................................................. 20

Fig. 14. Bank profiles of the sites where erosion pins were installed................................................... 20

Fig. 15. Estimates of net erosion or deposition over time from erosion pin measurements at eight East Fork Poplar creek kilometer (EFK) sites.

Fig. 16. Erosion pin and ice layers under the surface of creek bank soil at East Fork Poplar Creek kilometer 13.8.

Fig. 17. Photograph of creek bank at East Fork Poplar Creek kilometer 22 on January 31, 2014, 96 days after erosion pin installation.

Fig. 18. Calculated bank erosion rate for erosion pins located at several East Fork Poplar Creek kilometer (EFK) sites.

Fig. 19. Average bank erosion rate (BER) estimated from the kayak survey data versus average BER measured from the erosion pins. Dashed line indicates perfect agreement.

Fig. 20. Total mercury concentration in horizontal cores collected near the erosion pins on East Fork Poplar Creek in April 2014.

Fig. 21. (a) Photograph taken on April 23, 2014, of the historical release deposit (HRD) found at East Fork Poplar Creek kilometer (EFK) 18.2.

Fig. 22. Location of floodplain wells installed in the Mill Branch floodplain (MBFP) behind the Tennessee Valley Authority substation near East for Poplar Creek (EFPC) kilometer 15.7.

Fig. 23. Temperatures for surface water and groundwater at the East Fork Poplar Creek kilometer (EFK) 15.7 well cluster (Mill Branch floodplain [MBFP]-01 to MBFP-04).

Fig. 24. Panels indicate (a) pH, (b) specific conductance (Spec. Cond.), (c) dissolved oxygen (DO), and (d) oxidation-reduction potential (ORP) for surface water (East Fork Poplar Creek kilometer [EFK] 15.7) and groundwater (MBFP-01 to MBFP-04). 
Fig. 25. Dissolved $(<0.2 \mu \mathrm{m}$ ) concentrations of (a) nitrate, (b) ferrous iron, (c) sulfate, and (d) sulfide for surface water (East Fork Poplar Creek kilometer [EFK] 15.7) and groundwater (Mill Branch floodplain [MBFP]-01 to MBFP-04).

Fig. 26. Concentrations of dissolved (a) mercury (HgD) and (b) methylmercury (MeHgD) in surface water (East Fork Poplar Creek kilometer [EFK] 15.7) and groundwater (Mill Branch floodplain [MBFP]-01 to MBFP-04)

Fig. 27. Box-and-whisker plot of the percent dissolved methylmercury $(\mathrm{MeHg})(=100 \times$ $\mathrm{MeHgD} / \mathrm{HgD}$ ) for surface water (East Fork Poplar Creek kilometer [EFK] 15.7) and shallow groundwater (Mill Branch floodplain [MBFP] wells MBFP-01 to MBFP-04)............... 36

Fig. 28. (a) Total monthly precipitation (rain and snow) over the period of observation, and (b) water table gradient between creek bank wells 1, 2, and 3 and inland well number 4 .

Fig. 29. Total aqueous and aqueous + colloidal $\mathrm{HgT}$ in water incubated with water from upper First Creek and streambed sediments, floodplain soils, and stream bank soils collected from upper East Fork Poplar Creek at a water:soil ratio of 10:1.

Fig. 30. Total aqueous mercury (HgT) in water incubated with water from upper First Creek and from the Clinch River with floodplain soils from upper East Fork Poplar Creek at a water:soil mass ratio of 9:1.

Fig. 31. Total mercury (HgT) accumulation onto Chlamydomonas reinhardtii cells after incubation with water exposed to different soil types. Black bars show concentrations after $<10$ min of exposure, whereas gray bars show concentrations after $4 \mathrm{~d}$ of exposure.

Fig. 32. Model framework showing stream reaches, inorganic mercury (IHg) and methylmercury $(\mathrm{MeHg})$ inflow and outflow, and instream processes considered in the model.

Fig. 33. Average monthly flows (cubic meters/second [cms]) for Station 17 (1992-2013) and East Fork Poplar Creek kilometer (EFK) 5.4 (1960-1987) without flow augmentation.....

Fig. 34. Horizon Center (NH; East Fork Poplar Creek kilometer 5.4) 15 min increment flow data from February 13, 2012, to April 30, 2015 (cubic meters/second [cms]).

Fig. 35. Weekly flow weighted total mercury (HgT; unfiltered) sample data for Station 17 obtained from the Oak Ridge Environmental Information System was used to calculate weekly HgT fluxes.

Fig. 36. Concentration vs. flow relationships for New Horizon (East Fork Poplar Creek kilometer [EFK] 5.4) developed from stormflow sampling can be used to estimate $\mathrm{HgP}, \mathrm{HgD}$, total mercury ( $\mathrm{HgT}), \mathrm{MeHgP}, \mathrm{MeHgD}$, total $\mathrm{MeHg}(\mathrm{MeHgT})$, and total suspended solids (TSS) concentration and fluxes at EFK 5.4 under various flow conditions.

Fig. 37. Relationship of average weekly flow (cubic meters/second [cms]) at Horizon Center (NH; East Fork Poplar Creek kilometer [EFK] 5.4) to the weekly difference in total mercury flux (g) between EFK 5.4 and Station 17.

Fig. 38. Estimated mass of soil entering East Fork Poplar Creek because of bank erosion per 100 $\mathrm{m}$ reach (kilograms/year per $100 \mathrm{~m}$ ) calculated using bank erosion rate values, bank heights measured during the kayak survey, and assuming an average bulk density of $1.25 \ldots \ldots . . .55$

Fig. 39. Total mercury (HgT) bank soil sampling results from the center of the bank............................ 56

Fig. 40. Methylmercury ( $\mathrm{MeHg}$ ) bank soil sampling results from the center of the bank........................56

Fig. 41. Estimated total mercury flux per $100 \mathrm{~m}$ reach (kilograms/year per $100 \mathrm{~m}$ ) in East Fork Poplar Creek.

Fig. 42. Estimated methylmercury flux per 100-m reach (milligrams/year per $100 \mathrm{~m}$ ) in East Fork Poplar Creek. 57

Fig. 43. Estimated total mercury $(\mathrm{HgT})$ and methylmercury $(\mathrm{MeHg})$ flux per $100 \mathrm{~m}$ reach.....................58

Fig. 44. Monthly distribution of total mercury (HgT) flux for each modeled stream reach. .................... 59

Fig. 45. Monthly distribution of methylmercury $(\mathrm{MeHg})$ flux for each modeled stream reach. ................59

Fig. 46. Detailed floodplain concentration contouring used to estimate floodplain fluxes in East Fork Poplar Creek. 
Fig. 47. Biannual total mercury (HgT) sampling at four locations along East Fork Poplar Creek in summer and winter showing seasonal and upstream to downstream trends.

Fig. 48. Biannual total methylmercury (MeHgT) sampling at four locations along East Fork Poplar Creek in summer and winter showing seasonal and upstream to downstream trends.

Fig. 49. Seasonal averages for 2007-14 base flow samples show significant differences in inorganic mercury concentrations from the upstream to downstream East Fork Poplar Creek sampling locations in warm months (June) compared with cold months (December).

Fig. 50. Seasonal averages for 2007-14 base flow samples show significant differences in methylmercury concentrations from upstream to downstream East Fork Poplar Creek sampling locations in warm months (June) compared with cold months (December).

Fig. 51. Seasonally averaged flux estimates for 2007-14 base flow samples show significant differences in inorganic mercury fluxes on East Fork Poplar Creek in warm months (June) versus cold months (December).

Fig. 52. Seasonally averaged flux estimates for 2007-14 base flow samples show significant differences in methylmercury fluxes on East Fork Poplar Creek in warm months (June) versus cold months (December).

Fig. 53. Monthly instream methylmercury production by stream reach showing increased production downstream and in the summer.

Fig. 54. Relationship of aqueous mercury concentrations in Oak Ridge streams to the concentration of mercury in fish tissue.

Fig. 55. Estimated total suspended solids (TSS) fluxes and associated total mercury ( $\mathrm{HgT})$ concentrations.

Fig. 56. Time series of total mercury $(\mathrm{HgT})$ concentrations in water and fish (rock bass and redbreast sunfish) in lower East Fork Poplar Creek from 1989 to 2010.

Fig. 57. Concentrations of methylmercury ( $\mathrm{MeHg}$; light blue) and inorganic mercury (Hg; dark blue) in rock bass at two locations (upstream at East Fork Poplar Creek kilometer [EFK] 24 and downstream at EFK 6) in lower East Fork Poplar Creek.

Fig. 58. Diagram of the basic food web in lower East Fork Poplar Creek showing the pathways for bioaccumulation of mercury $(\mathrm{Hg})$ from the periphyton matrix to the top predator.

Fig. 59. Magnitude of the primary total mercury $(\mathrm{HgT})$ inputs to the lower East Fork Poplar Creek watershed under the no-management-action scenario.....

Fig. 60. Distribution of the total mercury (HgT) input for each stream reach in lower East Fork Poplar Creek under the no-management-action scenario.

Fig. 61. Magnitude of the primary total methylmercury (MeHgT) inputs to the lower East Fork Poplar Creek watershed under the no-management-action scenario.

Fig. 62. Distribution of the total methylmercury (MeHgT) input for each stream reach in lower

East Fork Poplar Creek under the no-management-action scenario.

Fig. 63. Predicted approximate total mercury ( $\mathrm{HgT})$ concentrations for each source reduction scenario.

Fig. 64. Scenario 1: Simulation of total mercury $(\mathrm{HgT})$ and total methylmercury (MeHgT) concentrations - no management action.

Fig. 65. Scenario 2: Simulation of total mercury (HgT) and total methylmercury (MeHgT) concentrations - no floodplain fluxes.

Fig. 66. Scenario 3: Simulation of total mercury $(\mathrm{HgT})$ and total methylmercury $(\mathrm{MeHgT})$ concentrations - no Station 17 flux.

Fig. 67. Scenario 4: Simulation of total mercury $(\mathrm{HgT})$ and total methylmercury (MeHgT) concentrations - no bank erosion flux.

Fig. 68. Scenario 5: Simulation of total mercury (HgT) and total methylmercury (MeHgT) concentrations - no Station 17 flux or bank erosion flux from EFKs 23-20 or 20-16. 
Fig. 69. Scenario 6: Simulation of total mercury $(\mathrm{HgT})$ and total methylmercury (MeHgT) concentrations - no Station 17 flux or bank erosion flux.

Fig. 70. Impact of reducing the methylation rate by $50 \%$ on predicted aqueous total methylmercury (MeHgT) concentrations for Scenario 5.

Fig. 71. Impact of methylation threshold factor on predicted aqueous total methylmercury (MeHgT) concentrations for Scenario 5 (see Table 24).

Fig. 72. Diagram of the Structural Thinking Experiential Learning Laboratory with Animation (STELLA) model for mercury accumulation in an individual rock bass for a single reach.

Fig. 73. Range of prey item compositions simulated for rock bass.

Fig. 74. Number of individuals representing three trophic levels (grazers, insectivores, and piscivores) during community sampling in spring and fall 2013 at four East Fork Poplar Creek kilometer (EFK) locations.

Fig. 75. Model simulated methylmercury (MeHg) concentrations in rock bass, redbreast sunfish, and stoneroller minnow at typical age of collection.

Fig. 76. Model simulated methylmercury (MeHg) concentrations in 5-year-old rock bass using the baseline temperature regime for lower East Fork Poplar Creek and the baseline -1, +1, and $+2{ }^{\circ} \mathrm{C}$.

Fig. 77. Model simulated methylmercury (MeHg) concentrations in 5-year-old rock bass at the second reach with different combinations of diets - invertebrate and fish prey items.

Fig. 78. Model simulated methylmercury $(\mathrm{MeHg})$ concentrations in 5-year-old rock bass with a baseline diet (i.e., 30\% invertebrates, $21 \%$ redbreast sunfish, and $49 \%$ stoneroller minnow) compared with site-specific sunfish:minnow proportions based on field observations of prey abundance.

Fig. 79. Predicted approximate methylmercury ( $\mathrm{MeHg}$ ) concentrations in fish for each source reduction scenario.

Fig. 80. Model simulated methylmercury (MeHg) concentrations in 5-year-old rock bass and sunfish, 3-year-old sunfish, and 2-year-old minnow at four stream reaches under no management action and five possible source reduction scenarios using periphyton $\mathrm{MeHg}$ concentrations derived from the watershed model.

Fig. 81. Model simulated methylmercury ( $\mathrm{MeHg}$ ) concentrations in 5-year-old rock bass at baseline periphyton concentrations and at reduced periphyton concentrations at $0.5,0.25$, and 0.15 of baseline.

Fig. 82. Primary instream inorganic mercury $(\mathrm{IHg})$ pathways.

Fig. 83. Primary instream methylmercury $(\mathrm{MeHg})$ pathways. 101 


\section{LIST OF TABLES}

Table 1. Five Year Review Issue (OF-2) .................................................................................. 3

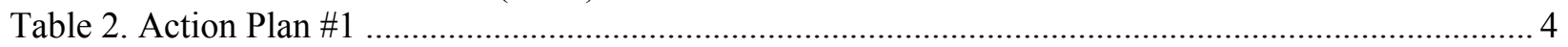

Table 3. East Fork Poplar Creek stream characteristics collected during the 2013 survey or

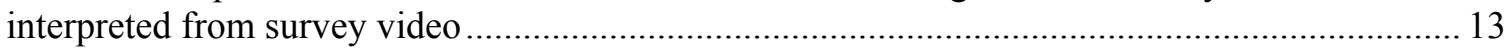

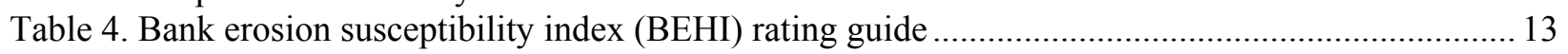

Table 5. Determination of Near Bank Stress (NBS) from radius of curvature (Rc) ................................ 14

Table 6. Summary statistics of bank erosion rate (BER; $\mathrm{ft} /$ year) and bank erosion hazard index (BEHI) from East Fork Poplar Creek kilometer 23 to the confluence with Poplar Creek............. 16

Table 7. Summary statistics of bank erosion rate (BER; feet/year) and bank erosion hazard index (BEHI) from Outfall 200 to East Fork Poplar Creek kilometer 23 ............................................. 18

Table 8. Estimates of mercury loading from bank erosion at various East Fork Poplar

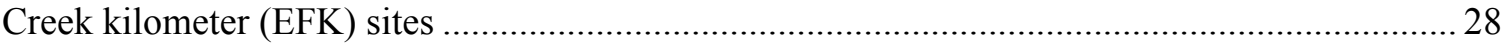

Table 9. Water quality parameters monitored in surface and groundwater ........................................... 32

Table 10. Total (HgT) and methylmercury $(\mathrm{MeHg})$ concentrations in different soil types collected from upper East Fork Poplar Creek (mg/kg dry sediment) ...................................................... 39

Table 11. Methylmercury (MeHg) and dissolved organic carbon (DOC) in sediment leaching tests ........ 40

Table 12. Oxidation-reduction potential (ORP), $\mathrm{pH}$, and conductivity over time in incubations

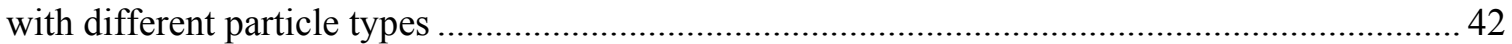

Table 13. Characteristics of filtered $(0.22 \mu \mathrm{m})$ water collected from the Clinch River and First Creek.

Table 14. Geospatial data sources.

Table 15. Total mercury (HgT) and total methylmercury (MeHgT) flux estimates from bank erosion per modeling reach....

Table 16. Area of floodplain for selected total mercury contour intervals for each stream reach in East Fork Poplar Creek

Table 17. Estimated mass of total mercury $(\mathrm{HgT})$ in the floodplain $(\mathrm{kg})$ for selected $\mathrm{HgT}$ contour intervals for each stream reach in East Fork Poplar Creek

Table 18. Estimated recharge volume (cubic meter) for selected total mercury (HgT) contour intervals for each stream reach per year in East Fork Poplar Creek

Table 19. Estimated mass of total mercury ( $\mathrm{HgT}$ ) leached (mg) per year from selected $\mathrm{HgT}$ contour intervals for each stream reach in East Fork Poplar Creek.

Table 20. Estimated mass of methylmercury ( $\mathrm{MeHg}$ ) leached (milligrams) per year from selected total mercury contour intervals for each stream reach in East Fork Poplar Creek.

Table 21. Estimated instream methylation rates (ng/ $\mathrm{m}^{2}$ per day) based on Fig. 50 data and stream geometry determined from the kayak survey of East Fork Poplar Creek

Table 22. Estimates of the concentration $(\mathrm{mg} / \mathrm{kg}$ ) of total mercury $(\mathrm{HgT})$ on total suspended solids (TSS) at various East Fork Poplar Creek locations ...

Table 23. The four Structural Thinking Experiential Learning Laboratory with Animation (STELLA) bioaccumulation modeling reaches of lower East Fork Poplar Creek designated by stream kilometer and each reach's corresponding historical fish sampling locations for mercury bioaccumulation.

Table 24. Description of select model runs with different input fluxes representing different source reduction scenarios

Table 25. Methylmercury ( $\mathrm{MeHg}$ ) concentrations in invertebrates and periphyton used in bioaccumulation model during watershed linked scenarios. 



\section{ACRONYMS}

\begin{tabular}{|c|c|}
\hline BEHI & bank erosion hazard index \\
\hline BER & bank erosion rate \\
\hline BMAP & Biological Monitoring and Abatement Program \\
\hline CERCLA & Comprehensive Environmental Response, Compensation, and Liability Act \\
\hline DOC & dissolved organic carbon \\
\hline DOE & US Department of Energy \\
\hline EFK & East Fork Poplar Creek kilometer \\
\hline EFPC & East Fork Poplar Creek \\
\hline EM & Environmental Management \\
\hline EPA & US Environmental Protection Agency \\
\hline ET & evapotranspiration \\
\hline FY & fiscal year \\
\hline FYR & Five Year Review \\
\hline GIS & geographic information system \\
\hline GPS & Global Positioning System \\
\hline $\mathrm{Hg}$ & mercury \\
\hline $\operatorname{Hg}(0)$ & elemental mercury \\
\hline $\mathrm{HgD}$ & dissolved mercury \\
\hline $\mathrm{HgP}$ & particulate mercury \\
\hline $\mathrm{HgT}$ & total mercury \\
\hline HRD & historical release deposit \\
\hline $\mathrm{IHg}$ & inorganic mercury \\
\hline$K_{d}$ & sorbent:water partition coefficient \\
\hline LEFPC & lower East Fork Poplar Creek \\
\hline MBFP & Mill Branch floodplain \\
\hline $\mathrm{MeHg}$ & methylmercury \\
\hline $\mathrm{MeHgD}$ & dissolved methylmercury \\
\hline $\mathrm{MeHgP}$ & particulate methylmercury \\
\hline MeHgT & total methylmercury \\
\hline NBS & Near Bank Stress \\
\hline NOAA & National Oceanic and Atmospheric Administration \\
\hline OREIS & Oak Ridge Environmental Information System \\
\hline ORNL & Oak Ridge National Laboratory \\
\hline ORP & oxidation-reduction potential \\
\hline ORWTF & Oak Ridge Wastewater Treatment Facility \\
\hline RER & Remediation Effectiveness Report \\
\hline RSI & Restoration Services, Inc. \\
\hline SFA & Science Focus Area \\
\hline STELLA & Structural Thinking Experiential Learning Laboratory with Animation \\
\hline TD & Technology Development \\
\hline TDEC & Tennessee Department of Environment and Conservation \\
\hline TSS & total suspended solids \\
\hline UCOR & URS | CH2M Oak Ridge LLC \\
\hline UEFPC & upper East Fork Poplar Creek \\
\hline USGS & US Geological Survey \\
\hline Y-12 or Y-12 Complex & Y-12 National Security Complex \\
\hline
\end{tabular}





\section{ACKNOWLEDGMENTS}

We would like to thank URS | CH2M Oak Ridge LLC (UCOR), especially Lynn Sims for her project oversight and funding for the project. The model could not have been completed without data contributions from multiple DOE contractor organizations, including: UCOR's Water Resources Restoration Program, UCOR's Mercury Remediation Technology Development Program, the Consolidated Nuclear Security, LLC (CNS) Y-12 Compliance Department, the UT-B Biological Monitoring and Abatement Program (BMAP), the DOE Office of Science Mercury SFA project (led by ORNL), and the DOE-EM Applied Field Research Initiative. We wish to thank US Department of Energy Oak Ridge Environmental Management (OREM) staff, who recognized the research need and value of a watershed approach to the mercury problem. The US Environmental Protection Agency and Tennessee Department of Environment and Conservation were also key early contributors to defining the action plan.

Thanks are also extended to Dr. Paul Ayers for his unique contribution to the analysis of bank soil fluxes; George Southworth for his contributions to early watershed modeling efforts; and Ami Riscassi and Carrie Miller, who took part in the first year of field work on the project. Maruthi Sridhar Balaji Bhaskar and Maria Martinez provided important contributions to the geospatial analyses, mapping, and data management activities. The authors also want to thank Wendy Hames and Tracy Clem for reporting and editing support. 



\section{EXECUTIVE SUMMARY}

This report summarizes a 3-year research project undertaken to better understand the nature and magnitude of mercury (Hg) fluxes in East Fork Poplar Creek (EFPC). This project addresses the requirements of Action Plan 1 in the 2011 Oak Ridge Reservation-wide Comprehensive Environmental Response, Compensation, and Liability Act Five Year Review (FYR). The Action Plan is designed to address a twofold 2011 FYR issue: (1) new information suggests mobilization of mercury from the upper and lower EFPC streambeds and stream banks is the primary source of mercury export during high-flow conditions, and (2) the current Record of Decision did not address the entire hydrologic system and creek bank or creek bed sediments.

To obtain a more robust watershed-scale understanding of mercury sources and processes in lower EFPC (LEFPC), new field and laboratory studies were coupled with existing data from multiple US Department of Energy programs to develop a dynamic watershed and bioaccumulation model. LEFPC field studies for the project focused primarily on quantification of streambank erosion and an evaluation of mercury dynamics in shallow groundwater adjacent to LEFPC and potential connection to the surface water. The approach to the stream bank study was innovative in using imagery from kayak floats' surveys from the headwaters to the mouth of EFPC to estimate erosion, coupled with detailed bank soil mercury analyses. The goal of new field assessments and modeling was to generate a more holistic and quantitative understanding of the watershed and the sources, flux, concentration, transformation, and bioaccumulation of inorganic mercury $(\mathrm{IHg})$ and methylmercury $(\mathrm{MeHg})$.

Model development used a hybrid approach that dynamically linked a spreadsheet-based physical and chemical watershed model to a systems dynamics, mercury bioaccumulation model for key fish species. The watershed model tracks total $\mathrm{Hg}$ and $\mathrm{MeHg}$ fluxes and concentrations by examining upstream inputs, floodplain runoff, floodplain leaching, bank soil erosion, and periphyton matrix dynamics. The bioaccumulation model tracks the feeding, growth, and mercury assimilation of representative individual fish through their typical life span using key inputs of fish size, water temperature, and diet. The LEFPC watershed was divided into five modeling reaches, and fluxes and concentrations are assessed at this spatial scale. Following are the key findings of the field and laboratory studies and the watershed and bioaccumulation modeling:

- The greatest flux of total mercury (HgT) in LEFPC is related to stormflow transport of Hgcontaminated solids entering the creek because of bank erosion in the upper reaches of the creek.

- The second greatest flux originates from upper EFPC (Station 17 representing the exit stream sampling point near the boundary of the Y-12 Complex), and appears to control base flow fluxes.

- The observed increase in $\mathrm{MeHg}$ concentration and flux from upstream to downstream is related primarily to instream methylation by periphyton and other biological activity.

- A meaningful substantial reduction of the HgT flux in LEFPC would require addressing the flux of HgT originating from bank erosion and from Station 17.

- Actions to reduce LEFPC floodplain leaching and runoff would not produce much of an impact on $\mathrm{HgT}$ or $\mathrm{MeHg}$ concentrations or fluxes unless other major sources are eliminated first.

This project addresses the Action Plan goal to evaluate the role of LEFPC bank soil sources and to consider the entire EFPC hydrologic system. Model conclusions are dependent on the data available at the time of this assessment. However, a robust understanding and quantification for some mercury-related parameters and relationships is still lacking; there is a continued need for field data collection and modeling improvements. Model predictions should be viewed cautiously, with comparisons of the magnitude of predictions between scenarios being more valid than absolute predictions of concentrations or fluxes. With continued updates and refinement, the watershed-scale model can be a useful, valuable tool for future EFPC research prioritization, technology development, and remedial decision-making. 



\section{INTRODUCTION}

\subsection{BACKGROUND}

This report summarizes the results of a first-of-its-kind, watershed-scale research evaluation of the sources of mercury in lower East Fork Poplar Creek (EFPC). The research is especially noteworthy for its innovative approach to better understanding the role of stream bank sources on the hydrologic system. This report is the culmination of a multiyear effort that used direct field and laboratory study coupled with monitoring and research data from multiple programs to develop a watershed-scale model of mercury flux. This research project addresses the requirements of Action Plan 1 in the 2011 Oak Ridge Reservation-wide Comprehensive Environmental Response, Compensation, and Liability Act (CERCLA) Five Year Review (FYR) (see following section).

The bioaccumulation of mercury in fish in EFPC (Fig. 1) has proven enigmatic over the past 30 years, in part because of increasing trends in lower EFPC that are not well understood (Southworth et al. 2011). When systemic monitoring of EFPC was initiated in 1982, mercury concentrations in fish were highest in the upper reaches of the stream near the mercury source within the Y-12 National Security Complex (Y12) and decreased downstream in a pattern consistent with dilution. That pattern was typical for the next 10 years, but after improvements in water quality following treatment of chlorinated discharges, a change began in the downstream pattern of mercury bioaccumulation. Eventually mercury concentrations increased in fish in the lower reaches of EFPC and decreased in the upper reaches. Mercury concentrations in LEFPC remain unresponsive to downstream dilution and are well above the US Environmental Protection Agency's (EPA's) fish-based ambient water quality criterion of $0.3 \mathrm{mg} / \mathrm{kg}$.

The following background information and key events have contributed to the recent research focus on LEFPC mercury sources:

- Fish mercury concentrations in recent years show that the highest concentrations in fish, and the highest concentrations of methylmercury in water, are from the farthest downstream sections of the creek.

- Higher fish concentrations in LEFPC are the result of a $20+$ year statistically significant increase in mercury bioaccumulation.

- Studies conducted in 2008-09 in LEFPC pointed to the potential importance of storm event mobilization of streambed and stream bank mercury sources (Southworth et al. 2013).

- Other studies of mercury contamination in flowing waters, such as those conducted in the South River, Virginia, have highlighted the importance of banks soils on mercury flux.

- New study information regarding LEFPC mercury sources was presented in the $2011 \mathrm{FYR}$ and identified as an issue with recommendations and follow-up actions.

- Regulatory reviews of the Remediation Effectiveness Report and the FYR identified these recent study findings as important considerations for future CERCLA decision-making. 




Fig. 1. The East Fork Poplar Creek watershed. (Notes: EFPC $=$ East Fork Poplar Creek; ORR = Oak Ridge Reservation; ETTP = East Tennessee Technology Park; ORNL = Oak Ridge National Laboratory; SNS = Spallation Neutron Source; Y-12 = Y-12 National Security Complex.)

\subsection{FIVE YEAR REVIEW ISSUE}

The 2011 Five Year Review identified a new FYR Issue (number OF-2) that in CERCLA parlance is relevant to the protectiveness of a remedial action and can trigger follow-up actions (Table 1). The primary issue is twofold: (1) new information suggests mobilization of mercury from the upper and lower EFPC streambed and stream banks is the primary source of mercury export during high-flow conditions, and (2) the current Record of Decision did not address the entire hydrologic system and creek bank or creek bed sediments. Details regarding the "new information" on LEFPC source issues are provided in the 2011 FYR and are published in Southworth et al. 2010 and Southworth et al. 2013. A key finding of these early studies was that most mercury (>90\%) exported from the EFPC watershed under wet weather flow arises from the watershed downstream from Y-12, not within the headwater industrial complex. Inputs from surface erosion of floodplain soils were determined in these studies to be a relatively small fraction $(\sim 10 \%)$ of total mercury export from LEFPC under wet weather conditions, indicating that mobilization of mercury from the streambed and stream banks was the source of most high-flow mercury export. A large fraction of the length of EFPC contains unvegetated, steep, mercury-contaminated stream banks potentially susceptible to erosional processes that could deposit mercury-contaminated soil into EFPC. 
Table 1. Five Year Review Issue (OF-2)

\begin{tabular}{|c|c|}
\hline Issue number & OF-2 \\
\hline Issue & $\begin{array}{l}\text { New information suggests mobilization of mercury from upper and lower East Fork Poplar } \\
\text { Creek (EFPC) streambed and stream banks is the primary source of mercury export during } \\
\text { high-flow conditions. The current Record of Decision did not address the entire hydrologic } \\
\text { system (e.g., upstream sources within the Y-12 National Security Complex) and did not address } \\
\text { creek bank or creek bed sediments. }\end{array}$ \\
\hline $\begin{array}{l}\text { Recommendation } \\
\text { and follow-up } \\
\text { action }\end{array}$ & $\begin{array}{l}\text { Assessment of the entire EFPC system from its headwaters within the Y-12 Complex } \\
\text { (Operable Unit 28) to its downstream confluence with Poplar Creek will be documented in the } \\
\text { Remediation Effectiveness Report (RER). Any potential action on this issue will be addressed } \\
\text { as part of the sequencing approach for mercury remediation throughout the system. }\end{array}$ \\
\hline $\begin{array}{l}\text { Responsible } \\
\text { party }\end{array}$ & US Department of Energy \\
\hline $\begin{array}{l}\text { Oversight } \\
\text { agencies }\end{array}$ & $\begin{array}{l}\text { US Environmental Protection Agency and Tennessee Department of Environment and } \\
\text { Conservation }\end{array}$ \\
\hline Milestone date & $\begin{array}{l}\text { Submit action plan per Federal Facility Agreement Section XXXI in fiscal year (FY) } 2012 \\
\text { D2 RER 7/30/2012; report on action plan completion/status in FY } 2013 \text { RER 3/30/2013. }\end{array}$ \\
\hline $\begin{array}{l}\text { Affects } \\
\text { protectiveness? } \\
\text { (yes/no) }\end{array}$ & $\begin{array}{l}\text { Current: Yes } \\
\text { Future: Yes }\end{array}$ \\
\hline
\end{tabular}

Recommendations to address Issue OF-2 included an assessment of mercury sources in the entire EFPC system, which was the focus of the study strategy defined for Action Plan 1.

\subsection{ACTION PLAN OBJECTIVES}

Action Plan \#1 was developed to address the FYR Issue OF-2. The plan was developed in a series of meetings and discussions with staff from URS | CH2M Oak Ridge LLC (UCOR); Restoration Services, Inc. (RSI); and Oak Ridge National Laboratory (ORNL). The current available information was considered and a consensus developed regarding the need for further field and laboratory evaluation, as well as modeling efforts, to close data gaps and provide a more robust understanding of the LEFPC hydrologic system. The proposed Action Plan \#1 was submitted on June 13, 2012 to the EPA and the Tennessee Department of Environment and Conservation (TDEC) for their review.

EPA comments on the draft Action Plan \#1 centered on the scope and length of time required to provide necessary information for decision-making and protectiveness determinations. Further discussion highlighted the system complexities, including spatial and temporal variability that cannot be determined in 1 year of study. Model development also can be a challenge, especially when site-specific data are limited. The plan and schedule were developed to maximize the information gained for the available financial resources and to address data needs for the next FYR in 2016.

The Action Plan 1 goals, study plan, schedule, and annual research objectives are provided in Table 2. In short, the Action Plan study strategy involves field and laboratory investigations to close data gaps and to better define mercury contributions from stream bank and channel sources, providing a better understanding of existing conditions. Newly collected data will be used-especially in year 3-to develop conceptual and systems-based models that can be used as tools to refine source estimates. Annual study summaries have been provided in the 2012-2015 RERs. The goal of this ORNL/TM report is to provide an overall summary of the 3 year research effort. Study findings also will be used as input for the 2016 FYR. 
Table 2. Action Plan \#1

FIVE YEAR REVIEW (FYR) ISSUE: OF-2, East Fork Poplar Creek (EFPC) Streambed and Bank Sediments

BACKGROUND: The role of instream and floodplain mercury sources on mercury flux, speciation, and bioavailability in the EFPC system is a complex issue that is not well understood. Various studies in Oak Ridge have provided useful information, but there remain numerous data gaps and high uncertainty associated with the various mercury source terms. The focus of the US Department of Energy's current and near-future remediation activities to address mercury contamination is in the "upstream areas" near the Y-12 National Security Complex, and any potential action downstream will need to be addressed as part of a sequencing approach to the system. Current efforts to address this issue will focus on providing information for future remedial decision-making as well as on closing data gaps on the roles of streambed and stream bank soil and sediment and shallow groundwater beneath the floodplain as sources of mercury and methylmercury to the lower EFPC (LEFPC) aquatic ecosystem.

PLAN/SCHEDULE: The action plan will involve conducting select field and laboratory investigations to close data gaps and to better define mercury contributions from stream bank and channel sources. Newly collected data will be used to develop conceptual and systems-based models that can be used as tools to refine source estimates. The evaluations will be conducted over a 3 year period leading to the $2016 \mathrm{FYR}$, and progress will be reported annually in the Remediation Effectiveness Report.

\section{ANNUAL FOCUS OF PROPOSED INVESTIGATIONS}

Fiscal year (FY) 2013: Investigations will focus on the leachability, methylation, and bioaccumulation characteristics of four mercury sources (floodplain soil, sediment, bank soil, and facility suspended sediment) to LEFPC. An initial evaluation of shallow groundwater beneath mercury-contaminated soil areas of the LEFPC floodplain will be conducted.

FY 2014: The focus of second-year investigations is to scale up field and laboratory data to the EFPC hydrologic watershed as a whole, using a systems-based quantitative model framework. Physical and chemical information key to modeling efforts will be obtained from previous reports or publications; unpublished data from other monitoring programs; available remote sensing, geographic information system data, and land cover data; and direct measurement. Results will be presented in the Remediation Effectiveness Report.

FY 2015: The final product of the 3 year effort is to provide a systems-based quantitative model of use in (1) defining the relative LEFPC source contributions, (2) simulating various changes in source assumptions or environmental management scenarios, and (3) visualizing complex mercury processes and model runs for decision-maker purposes. 


\section{STUDY APPROACH AND MODEL DEVELOPMENT}

One of the challenges in evaluating mercury transport and fate in EFPC is that there have been a number of separate and disparate studies over time that have never been fully coordinated or pulled together into a cohesive framework or conceptual model of stream mercury processes. Very early in the process of defining an approach for the project, it was determined that a study plan needed to 1) gather available monitoring and research data from other relevant programs, 2) develop, revise, and improve a conceptual model of likely LEFPC mercury sources, pathways and controlling processes, 3) identify data gaps and field and laboratory research needs, and 4) define a quantitative modeling approach that ties all of the source compartments and pathways together into a realistic framework for understanding mercury processes and transformations at the watershed scale (Fig. 2). The final modeling product, incorporating existing knowledge and new insights from direct field and laboratory study, is designed to provide a reasonable representation of the existing roles of mercury source terms as well as a quantitative tool for evaluating water and fish mercury concentrations and fluxes in response to potential changes in source term fluxes.

Objective:
What are the roles of LEFPC $\mathrm{Hg}$ sources and can we provide a watershed scale understanding?

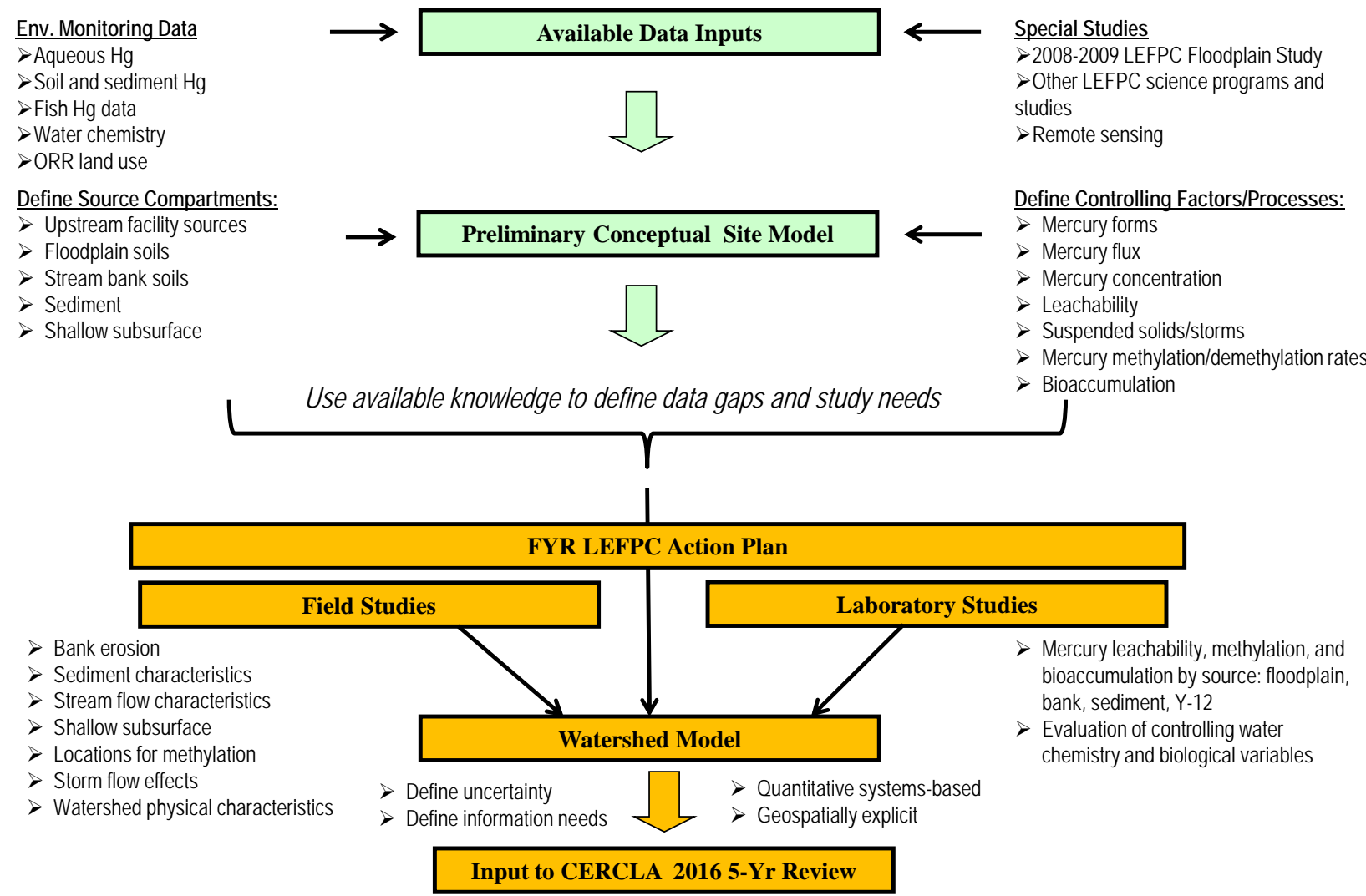

Fig. 2. General project-level approach to address Action Plan 1's goal of providing a watershed-scale understanding of the role of lower East Fork Poplar Creek (LEFPC) mercury sources. 
The extensive data available from multiple programs was used to identify the significant mercury source zone and pathway compartments contributing and sustaining mercury fluxes on a watershed and subwatershed scale and to develop a generalized conceptual model for EFPC (Figure 3). Important components of the conceptual model include the inflow of water and mercury from Y-12 and subwatersheds downstream of Y-12 (Figure 3). Primary sources of mercury influx to EFPC, downstream of Y-12, include the floodplain runoff and infiltration and bank erosion processes depicted in Figure 4. Once the mercury reaches EFPC a complex set of interconnected instream processes, shown on Figure 5, results in mercury transformations and partitioning amongst stream sediment, suspended solids and dissolved phases and alternating high and low flow conditions causes mobilization and deposition of particulates. The production of $\mathrm{MeHg}$ and biological uptake through the food chain are also important instream processes represented on Figure 5. These instream processes can have a significant impact on the risk of mercury transport and exposure.

The EFPC conceptual model provides the general basis for the way the source term data and mercury transformations were handled in the quantitative watershed modeling effort, which is the key product of the Action Plan 1 studies. The quantitative modeling effort, used for evaluating the role of mercury sources and potential future remedial prioritization, employed a hybrid approach that integrates a spreadsheet-based watershed model linked dynamically to a STELLA-based mercury bioaccumulation model. In the watershed model, physical and chemical processes that are controlling $\mathrm{Hg}$ and $\mathrm{MeHg}$ fluxes and concentrations are assessed by examining upstream inputs, floodplain runoff, floodplain leaching, bank soil erosion, instream processes and estimating biologically mediated $\mathrm{MeHg}$ production. The bioaccumulation model tracks the feeding, growth, and mercury assimilation of representative individual fish - from three species that represent three different trophic levels - through their typical life span using fish size, water temperature, and diet as key inputs.

The physical/chemical watershed model and biological uptake model developed for this project are discussed in detail in Section 3.3. Provided here is an overview of the model platform and how it is used to integrate the extensive multidisciplinary data from EFPC into a more holistic understanding of the watershed. EFPC was divided into 5 reaches (subwatersheds) that were selected to maintain similarity of stream type within each reach and to ensure that each reach is represented by a long-standing Biological Monitoring and Abatement Program (BMAP) fish collection site (Fig. 6). In the model, flow, total suspended solids (TSS), and mercury fluxes move from upstream reaches to downstream. Each reach then incorporates any changes in flux that are specific to that reach. As shown in Fig. 7, the model includes estimates of fluxes of $\mathrm{IHg}$ and $\mathrm{MeHg}$ coming into each of the reaches and the impacts of instream processes occurring in each of the reaches. The influx to each stream reach includes estimates of what is flowing into the reach from the upstream reach, additional inputs from bank erosion, and overland flow and infiltration from the floodplain. Estimates of the inflow of clean water and clean TSS that enter the system within each of the reaches and its impact on $\mathrm{IHg}$ and $\mathrm{MeHg}$ concentrations also are included in the model. Instream processes considered include $\mathrm{MeHg}$ production (e.g., from periphyton), and select sediment deposition and mobilization ( $\mathrm{IHg}$ and $\mathrm{MeHg}$ ), and partitioning processes. With this modeling framework defined, site-specific data from the EFPC watershed was used to help parameterize the mercury processes, transformations, and connections linking various model compartments (subwatersheds) and defining within-compartment interactions. The model is configured so that the watershed impacts of a reduction in flux in one or more of the mercury inputs can be assessed. 


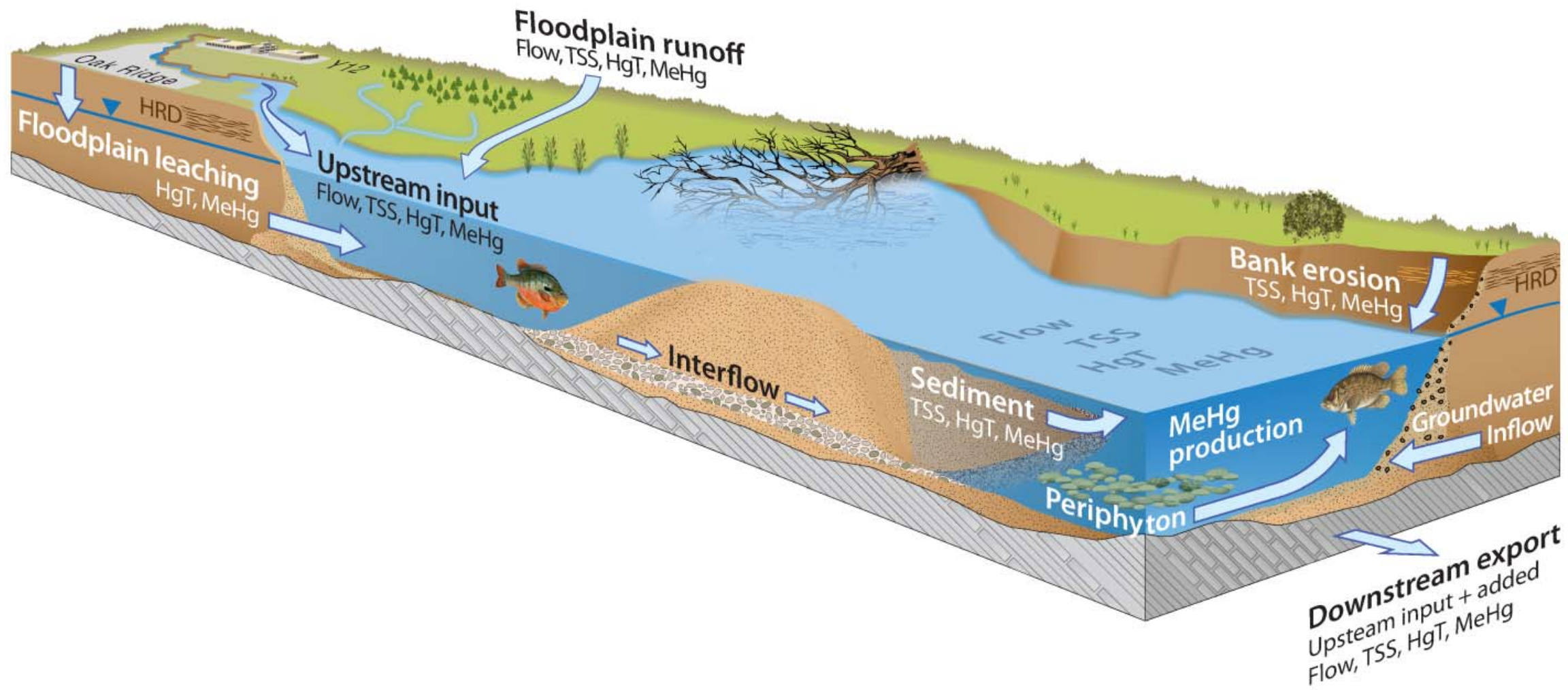

Fig. 3. Conceptual model for understanding mercury source contributions to Lower East Fork Poplar Creek. (Notes: $\mathrm{TSS}=$ total suspended solid; $\mathrm{HgT}=$ total mercury; $\mathrm{MeHg}=$ methylmercury; $\mathrm{HRD}=$ Historical release deposits.) 

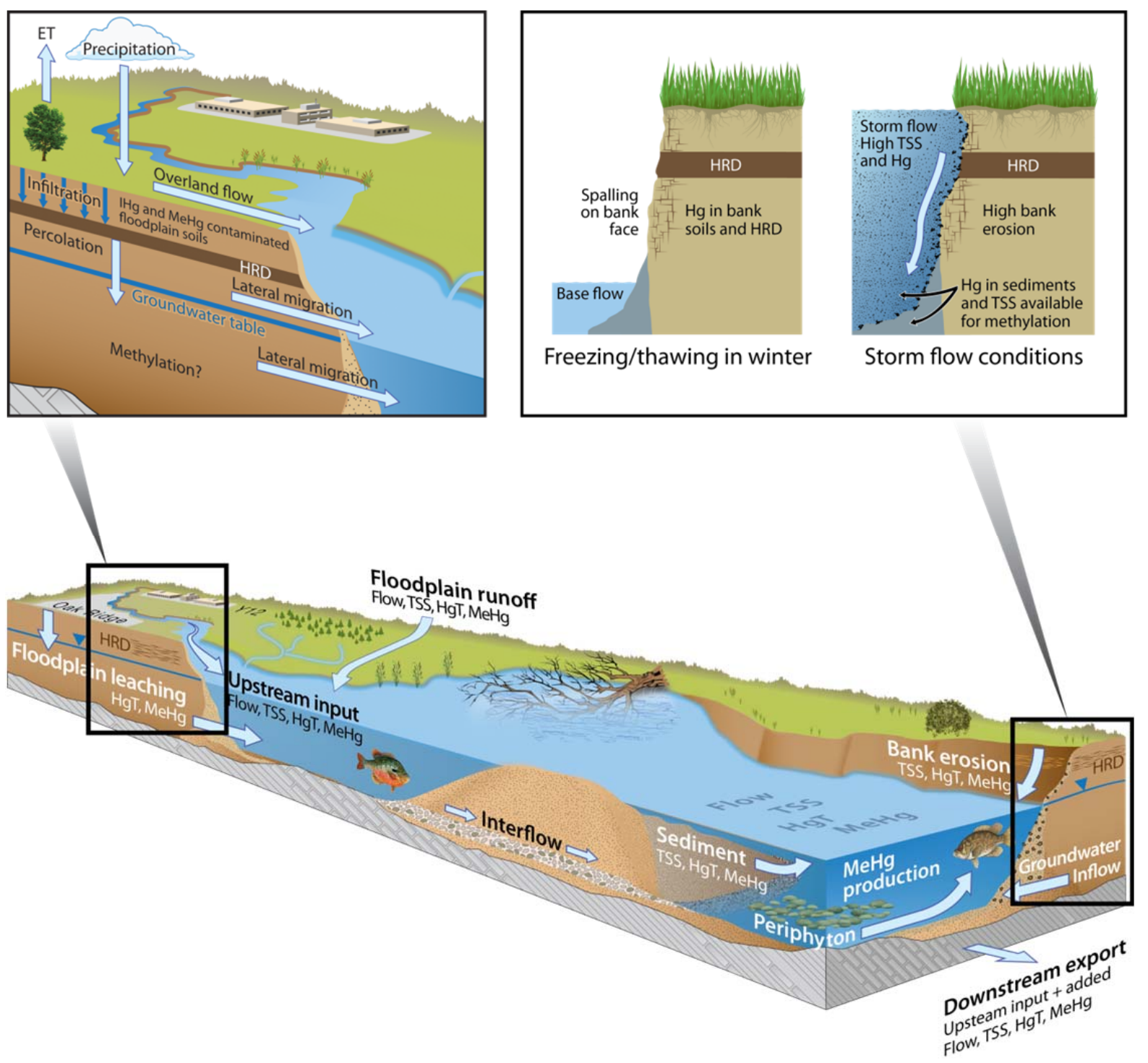

Fig. 4. Conceptual model for understanding floodplain and bank soil mercury flux to Lower East Fork Poplar Creek.(Notes: ET=Evapotranspiration; TSS = total suspended solid; $\mathrm{HgT}=$ total mercury; $\mathrm{MeHg}=$ methylmercury; $\mathrm{HRD}=$ Historical release deposits.) 


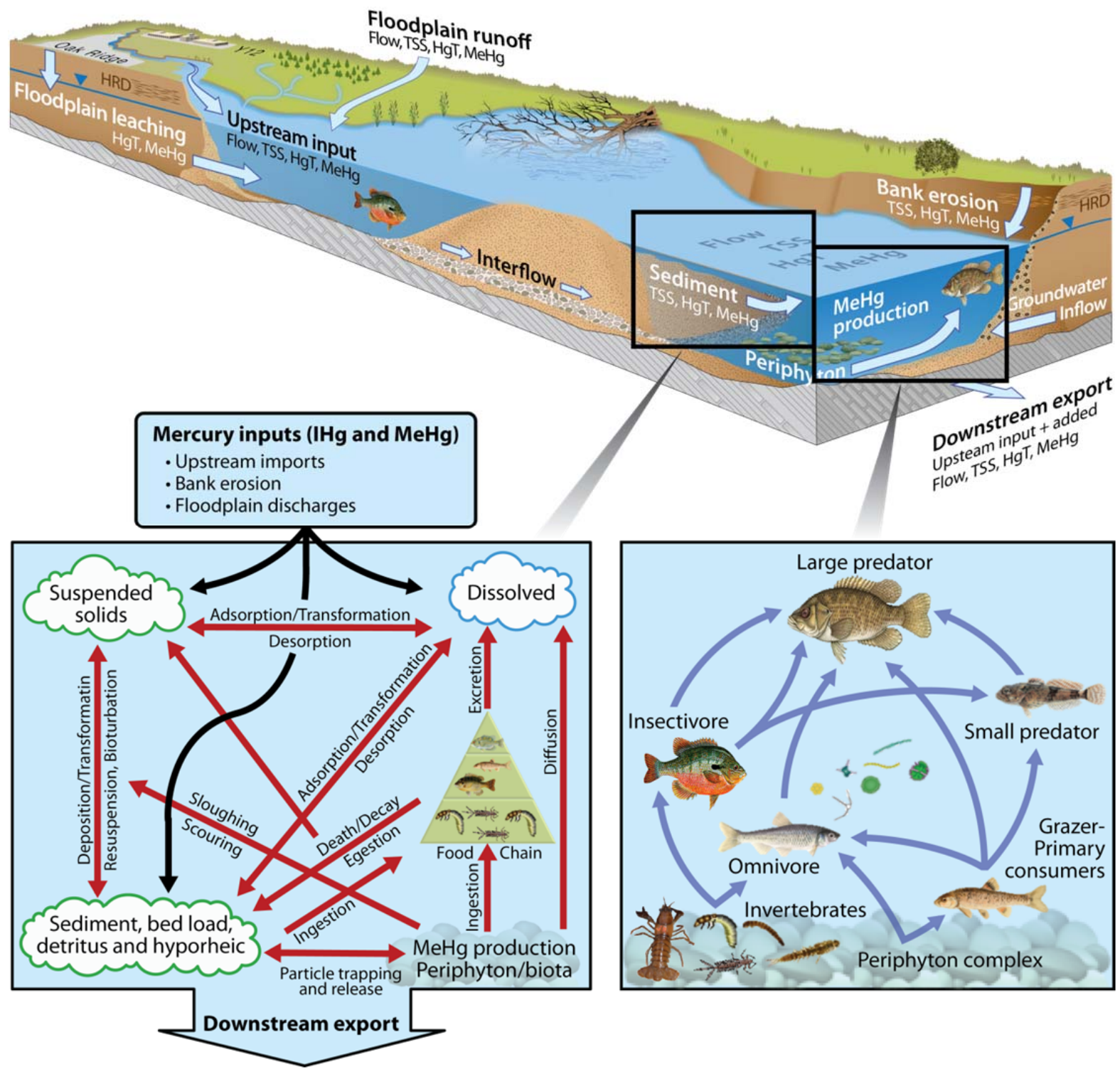

Fig. 5. Conceptual model for understanding instream mercury processes including bioaccumulation in Lower East Fork Poplar Creek. (Notes: TSS = total suspended solid; HgT = total mercury; $\mathbf{M e H g}$ = methylmercury; HRD = Historical release deposits.) 


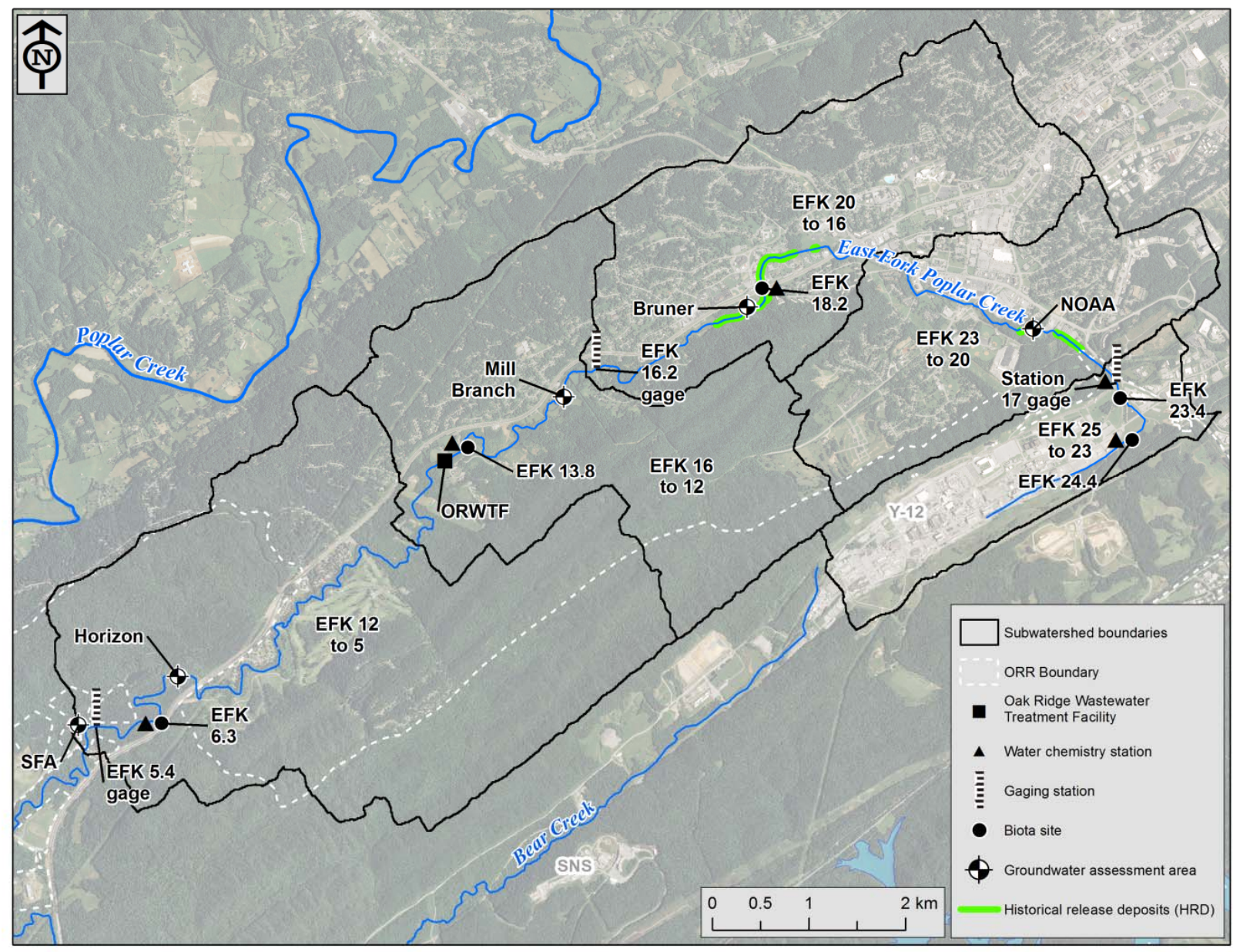

Fig. 6. Key EFPC monitoring locations and subwatershed boundaries. (Notes: EFK = East Fork Poplar Creek kilometer; NOAA = National Oceanic and Atmospheric Administration; ORWTF = Oak Ridge Wastewater Treatment Facility; ORR = Oak Ridge Reservation; SFA = Science Focus Area; SNS = Spallation Neutron Source; Y-12 = Y-12 National Security Complex.) 


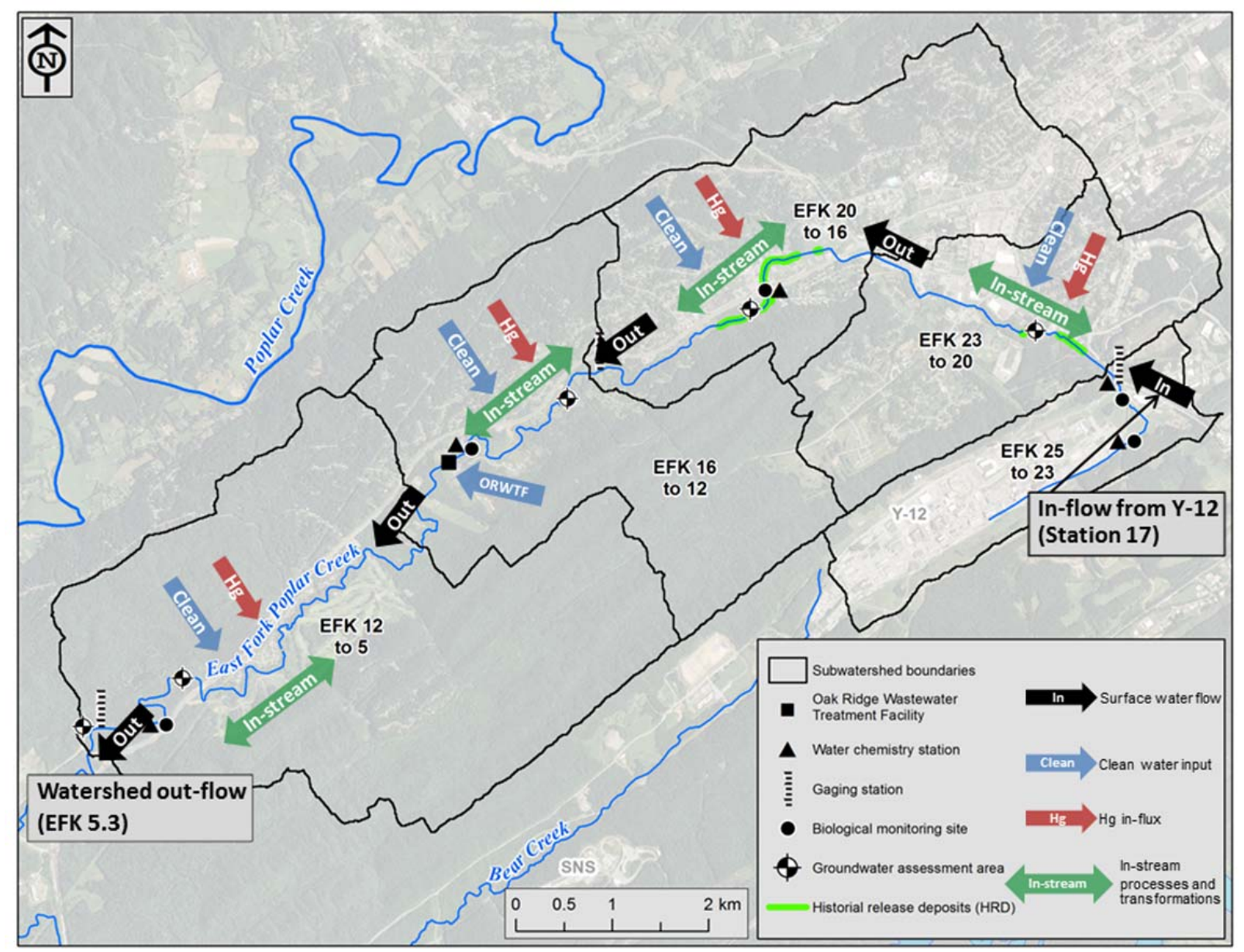

Fig. 7. Key watershed fluxes and inputs. (Notes: EFK = East Fork Poplar Creek kilometer; $\mathrm{Hg}=$ mercury; ORWTF = Oak Ridge Wastewater Treatment Facility; SNS = Spallation Neutron Source; Y-12 = Y-12 National Security Complex.)

\section{EVALUATION OF CURRENT WATERSHED SCALE MERCURY PROCESSES}

To obtain a watershed-scale understanding of current mercury processes in EFPC, this project used existing data sources from other programs coupled with direct field and laboratory study to help inform a watershed-scale model. Following is a summary of the results of field (Section 3.1) and laboratory studies (Section 3.2), and a summary of model input parameters and assumptions (Section 3.3).

\subsection{FIELD STUDIES}

The field study component focused primarily on quantification of stream bank erosion and an evaluation of mercury dynamics in shallow groundwater adjacent to East Fork Poplar Creek and the potential connection to the surface water. Where applicable, data collected and generated from the field and laboratory studies described in this section were used as inputs to the watershed model described in Sections 3.3 and 4. 


\subsubsection{Quantification of Stream Bank Erosion}

\section{Approach}

Two interrelated approaches have been adopted to obtain quantitative estimates of stream bank erosion along lower EFPC. The first of these approaches involves the use of Global Positioning System (GPS)referenced video mapping of the entire length of LEFPC to its confluence with Poplar Creek. The second approach involves the installation of erosion pins at a few sites identified from the video survey to ground-truth the estimates originating from the video survey. Each of these approaches is described briefly below.

GPS-based video mapping - Dr. Paul Ayers of the Biosystems Engineering and Soil Science Department at the University of Tennessee was contracted to map the LEFPC stream bank and substrate. The work included the following three components:

1. Conduct a stream survey to acquire georeferenced video images and physical measurements of stream bank and creek conditions.

2. Develop geographic information system (GIS) maps of the stream bank condition and areas of high erosion potential using a modified bank erosion hazard index (BEHI) and stream erosivity from a modified Near Bank Stress (NBS).

3. Determine total daily sediment loads from modified BEHI, NBS, and stream gauge discharge hydrographs.

A GPS-based, kayak-mounted above-water and underwater video mapping and electronic sensor system was used to survey stream bank and erosion conditions on EFPC. Dr. Ayers and his team conducted two initial surveys on the lower $23 \mathrm{~km}$ of EFPC during leaf-off and leaf-on conditions in March and July 2013. For these two surveys, two identically instrumented kayaks were used to provide redundancy of coverage in case of equipment failure. Each kayak was equipped with three GPS-based video cameras mounted pointing right, left, and forward. The cameras recorded georeferenced digital video of the stream banks, and side-pointing lasers measured stream width. During the leaf-on survey, light meters also were mounted on both kayaks to obtain estimates of the length of stream that was relatively covered by canopy. A third survey in August 2013 collected information along the section of EFPC from Outfall 200 to East Fork Poplar Creek kilometer (EFK) 23, thereby overlapping slightly with the upper end of the previous surveys. A light meter also was mounted on the kayak for this survey. Stream and bank attributes were acquired from interpretation of the recorded video and kayak sensor measurements. Table 3 lists the attributes collected during the survey or subsequently determined from the survey video. Additional information on the kayak data collected for this project is referenced in Appendix A. 
Table 3. East Fork Poplar Creek stream characteristics collected during the 2013 survey or interpreted from survey video

\begin{tabular}{cccc}
\hline Attribute & Description & Source & Units \\
\hline UTC & Coordinated universal time & GPS unit & HH:MM:SS \\
Latitude & Latitude coordinate & GPS unit & Degrees \\
Longitude & Longitude coordinate & GPS unit & Degrees \\
River width & River width & Laser distance sensors & Meters \\
Velocity & Velocity of the kayak per GPS unit & GPS unit & Knots per \\
hirection & Direction of the turn as the kayak & Video interpretation & Unitless \\
Bank length & moves downstream & GPS unit & Feet \\
Temperature & Distance between GPS points & Sensor & Degrees \\
Intensity & Water temperature & Celsius \\
Depth & Light intensity & Light meter & Lux \\
Bank angle & Score based on range of bank angles & Video interpretation & Unitless \\
Bank height & Bank height & Video interpretation & Feet \\
Surface protection & $\begin{array}{l}\text { Percentage of the stream bank covered } \\
\text { blant roots, downed logs, branches, }\end{array}$ & Video interpretation & Percent \\
riparian diversity & Score based on quantity and diversity \\
of vegetation along the bank & Video interpretation & Unitless
\end{tabular}

Notes: GPS = Global Positioning System; HH:MM:SS = hours, minutes, and seconds.

A modified BEHI score was determined from bank height, bank angle, surface cover, and riparian diversity information. BEHI scores were converted to erosion susceptibility ratings as shown in Table 4.

Table 4. Bank erosion susceptibility index (BEHI) rating guide

\begin{tabular}{cc}
\hline Erosion susceptibility rating & BEHI Score \\
\hline No erosion & 0 \\
Moderate & $\leq 24.75$ \\
Moderate high & $>24.75$ and $\leq 34.75$ \\
High to very high & $>34.75$ and $\leq 42.5$ \\
Very high to extreme & $>42.5$ and $\leq 48$ \\
Extreme & $>48$ \\
\hline
\end{tabular}

The radius of curvature was determined from the location of GPS points and was used to calculate the NBS scores based on the ranges listed in Table 5. 
Table 5. Determination of Near Bank Stress (NBS) from radius of curvature (Rc)

\begin{tabular}{ccc}
\hline NBS description & NBS value & Rc/(River width) \\
\hline Very low & 1 & $>3.0$ \\
Low & 2 & $2.21-3.0$ \\
Moderate & 3 & $2.01-2.2$ \\
High & 4 & $1.81-2.0$ \\
Very high & 5 & $1.5-1.8$ \\
Extreme & 6 & $<1.5$ \\
\hline
\end{tabular}

The BEHI and NBS scores were used to estimate total stream bank erosion and to identify locations of high erosion and stream bank rescission using the North Carolina Piedmont Region Bank Erosion Prediction Curves (Doll 2003).

Erosion pins-Erosion pins are a widely used method to make point estimates of erosion or deposition. The method consists of driving a narrow diameter metal rod ( 0.25 in. diameter $\times 24-36$ in. long) into the stream bank so it is flush with the surface. To quantify erosion, the length of exposed pin is measured using a washer placed over the pin and against the soil surface to give a base from which to measure. Deposition is measured similarly after carefully exposing the tip of the pin after burial. Observations made in the field are needed to distinguish between deposition and material slump from higher on the creek bank. Measurements are made at regular intervals (e.g., quarterly) and can be made after significant rain events. Mean bank erosion rates (BER) are calculated and combined with measurements of reach length and bank height to estimate volume and mass of erosion.

Bank soil sampling and analysis for total mercury - In conjunction with the erosion pin work, samples of bank soil were collected and analyzed for total mercury content. Estimates of bank erosion coupled with total mercury content of eroded soils are needed to identify bank locations that contribute the greatest load of mercury to the creek on an annual basis. Bank samples were collected at the same vertical elevation as erosion pins but some distance away to avoid inducing erosion artifacts. Two sampling methods were used. In the first collection method, $\sim 1$ in. of surface material was scraped into an appropriate container and returned to the lab for analysis. The second collection method used $1 \mathrm{in}$. diameter $\times 24 \mathrm{in}$. long polycarbonate tubes pushed $12 \mathrm{in.} \mathrm{into} \mathrm{the} \mathrm{creek} \mathrm{bank} \mathrm{and} \mathrm{then} \mathrm{pulled} \mathrm{out.} \mathrm{The} \mathrm{amount} \mathrm{of} \mathrm{material}$ recovered was recorded, and upon return to the lab, cores were logged and sectioned at 1 in. intervals. Each section was homogenized and a subsample taken for total mercury analysis by a Direct Mercury Analyzer. Another subsample was taken for moisture content determination.

\section{Results}

GPS-based video mapping - Preliminary results delivered by Dr. Ayers went through a quality assurance process at ORNL. One goal of the quality assurance process was to identify unusual values in the records such as missing, negative, or zero. Another goal was to replicate and document the calculations used by Dr. Ayers to estimate the attributes derived from other attributes through some calculations and to ensure results matched the data delivered. Calculations revised during the quality assurance process included checking that the correct NBS factor was assigned to each record based on the radius of curvature/river width. BEHI results also were revised by adding the bank angle, bank height/bankfull height ratio, surface protection, and riparian diversity. Finally, the calculations used to determine bank erosion rate values also were replicated.

BEHI scores from EFK 23 to the confluence with Poplar Creek were estimated separately for the left and right banks of the creek. BEHI scores in East Fork Poplar Creek reached a high-very high rating of 34.8 in a small section of $180 \mathrm{~m}$ along EFK 21 (Fig. 8). The rest of the creek had a BEHI rating of either 
moderate or high-moderate. The average BEHI score for the left bank was 20.3, whereas the average BEHI score on the right bank was 22.15 (Table 6). In both cases, the results show a low erosion susceptibility score. $\mathrm{BEHI}$ in both banks ranged from no erosion $(\mathrm{BEHI}=0)$ to 34.8 . No erosion was found in areas where the creek bed consists of concrete.

Bank erosion rates from EFK 23 to the confluence with Poplar Creek also were calculated separately for the left and right banks of the creek. The rates for both banks were similar. The mean BER on the left bank was $0.0623 \mathrm{ft} /$ year, whereas it was 0.0658 on the right bank (Table 6). Erosion rates ranged from 0 to $0.7208 \mathrm{ft} /$ year, although the distribution of rates results was skewed with between 60 and $64 \%$ of the values in both banks ranging between 0.01 and $0.02 \mathrm{ft} /$ year (Fig. 9). Approximately $5 \%$ of the points in both banks have an erosion rate of 0.7208 . As with BEHI scores, areas where erosion rate are zero also were identified as sections where the creek bed consisted of concrete and, therefore, erosion will not occur.

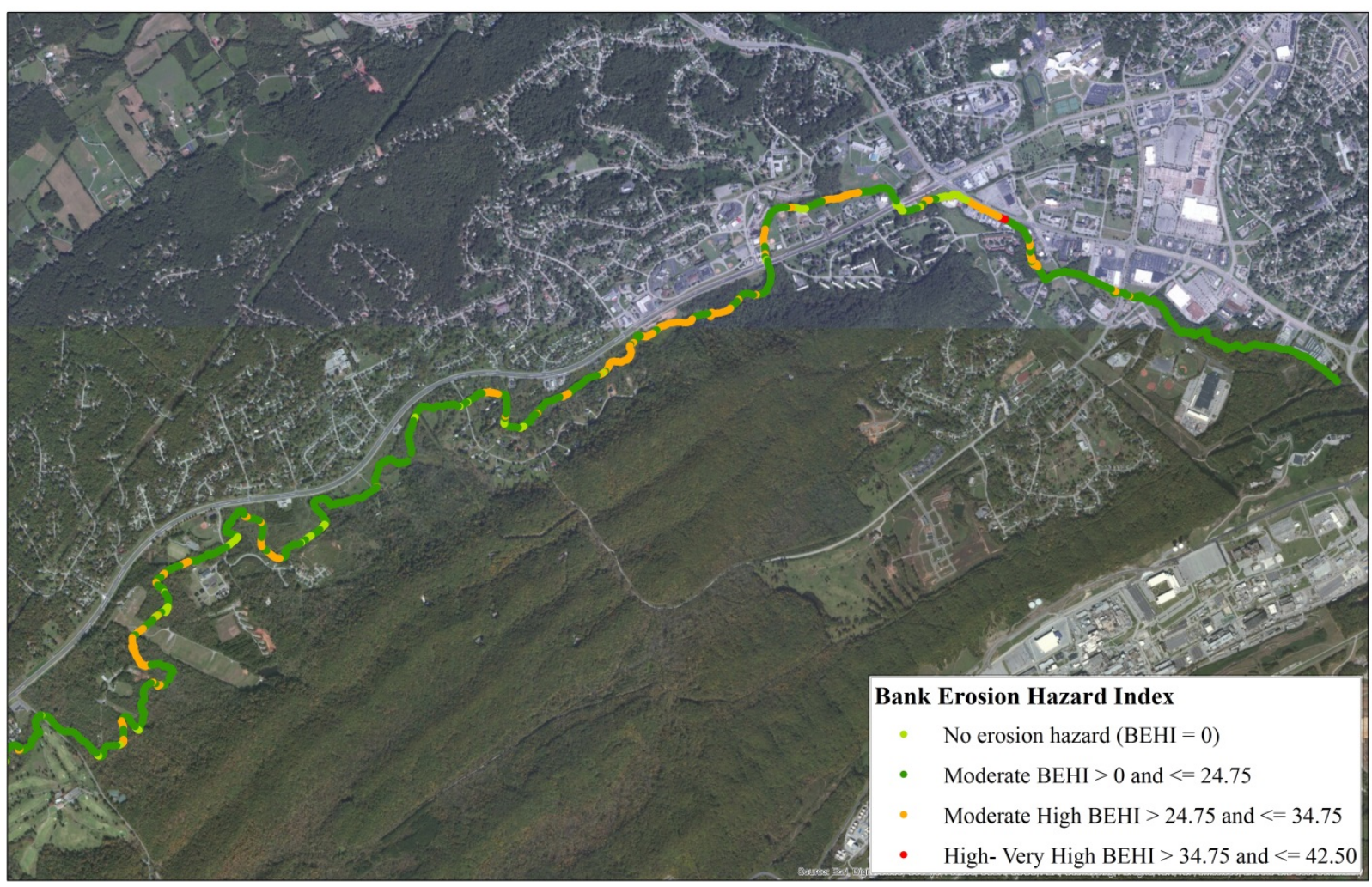

Fig. 8. Bank erosion hazard index (BEHI) values from analysis of the 2013 East Fork Poplar Creek stream bank video. The reach shown is approximately from East Fork Poplar Creek kilometer (EFK) 23 to EFK 12 (right to left). 
Table 6. Summary statistics of bank erosion rate (BER; $\mathrm{ft} / \mathrm{year}$ ) and bank erosion hazard index (BEHI) from East Fork Poplar Creek kilometer 23 to the confluence with Poplar Creek

\begin{tabular}{lcccc}
\hline \multicolumn{1}{c}{ Statistic } & $\begin{array}{c}\text { Left bank } \\
\text { BER }\end{array}$ & $\begin{array}{c}\text { Right bank } \\
\text { BER }\end{array}$ & $\begin{array}{c}\text { Left bank } \\
\text { BEHI }\end{array}$ & $\begin{array}{c}\text { Right bank } \\
\text { BEHI }\end{array}$ \\
\hline Mean & 0.0623 & 0.0658 & 20.2327 & 22.1503 \\
Standard error & 0.0011 & 0.0011 & 0.0448 & 0.0447 \\
Median & 0.0060 & 0.0088 & 22.25 & 23.75 \\
Mode & 0.0060 & 0.0060 & 22.25 & 26.25 \\
Standard deviation & 0.1748 & 0.1770 & 7.1395 & 7.1181 \\
Minimum & 0 & 0 & 0 & 0 \\
Maximum & 0.7208 & 0.7208 & 34.85 & 34.85 \\
\hline
\end{tabular}

\section{Histogram of Bank Erosion Rate}

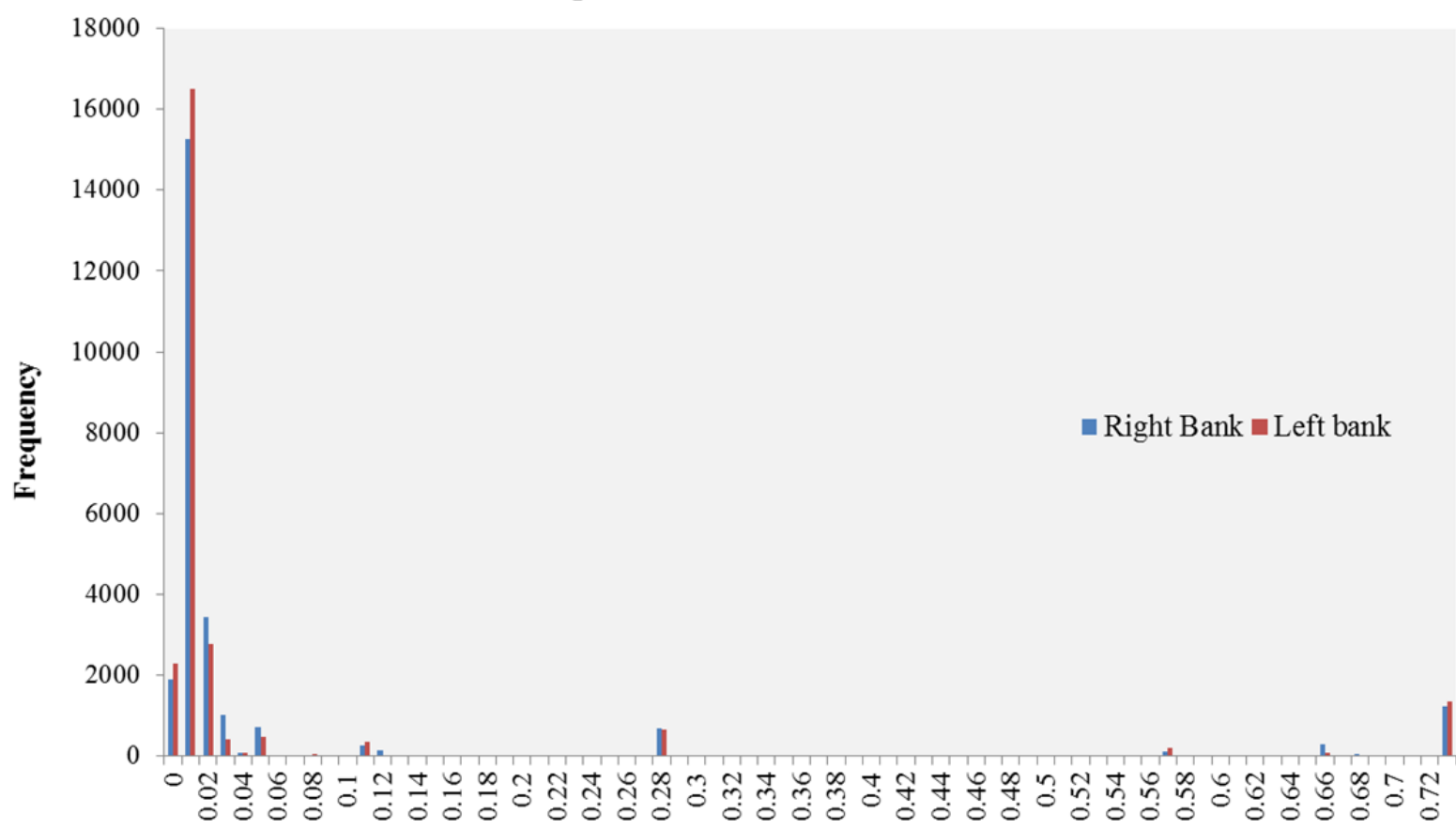

Bank Erosion Rate (ft/yr)

Fig. 9. Histogram of the bank erosion rate of the left and right banks from East Fork Poplar Creek kilometer 23 to the confluence with Poplar Creek. 
Erosion rates fluctuate along the creek from EFK 23 to the confluence with Poplar Creek (Fig. 10). Rates start with an average of $0.044 \mathrm{ft} /$ year around EFK 23 and increase $70 \%$ to $0.151 \mathrm{ft} /$ year in EFK 22 . Rates decrease to the second lowest level on the creek with $0.0126 \mathrm{ft} /$ year along EFK 19. Rates increase again and then fluctuate through EFK 13, where average erosion rates decrease to $0.042 \mathrm{ft} / \mathrm{year}$. Erosion rates are $0.013-0.052 \mathrm{ft} /$ year at EFK 13.2 and then reach their lowest value at the confluence with Poplar Creek.

BEHI results for the survey done from Outfall 200 to EFK 23 are shown in Fig. 11. BEHI scores in this survey also were estimated separately for the left and right banks of the creek. BEHI scores in this section of the creek reached a moderate-high rating of 28.3 along the right bank in a small section of EFK 19. The rest of the creek had a BEHI rating of either moderate or no erosion. The average BEHI scores in both banks show low ratings of 4.9 and 5.9 (Table 7). The low average was caused by approximately $66 \%$ of the records having a BEHI value of 0 , or no erosion. No erosion was found in areas where the creek bed consisted of concrete.

Bank erosion rates from Outfall 200 to EFK 23 also were calculated separately for the left and right banks of the creek. The average BER on the left bank was $0.0096 \mathrm{ft} /$ year, whereas it was $0.0152 \mathrm{ft} /$ year on the right bank (Table 7). Erosion rates ranged from 0 to $0.7208 \mathrm{ft} /$ year, although most of the creek showed skewed erosion rates, and approximately $90 \%$ of the values in both banks range from 0 to $0.01 \mathrm{ft} /$ year (Fig. 12). As in the case with BEHI scores, areas where erosion rates equal zero were identified as areas where the creek bed consists of concrete, where erosion will not occur.

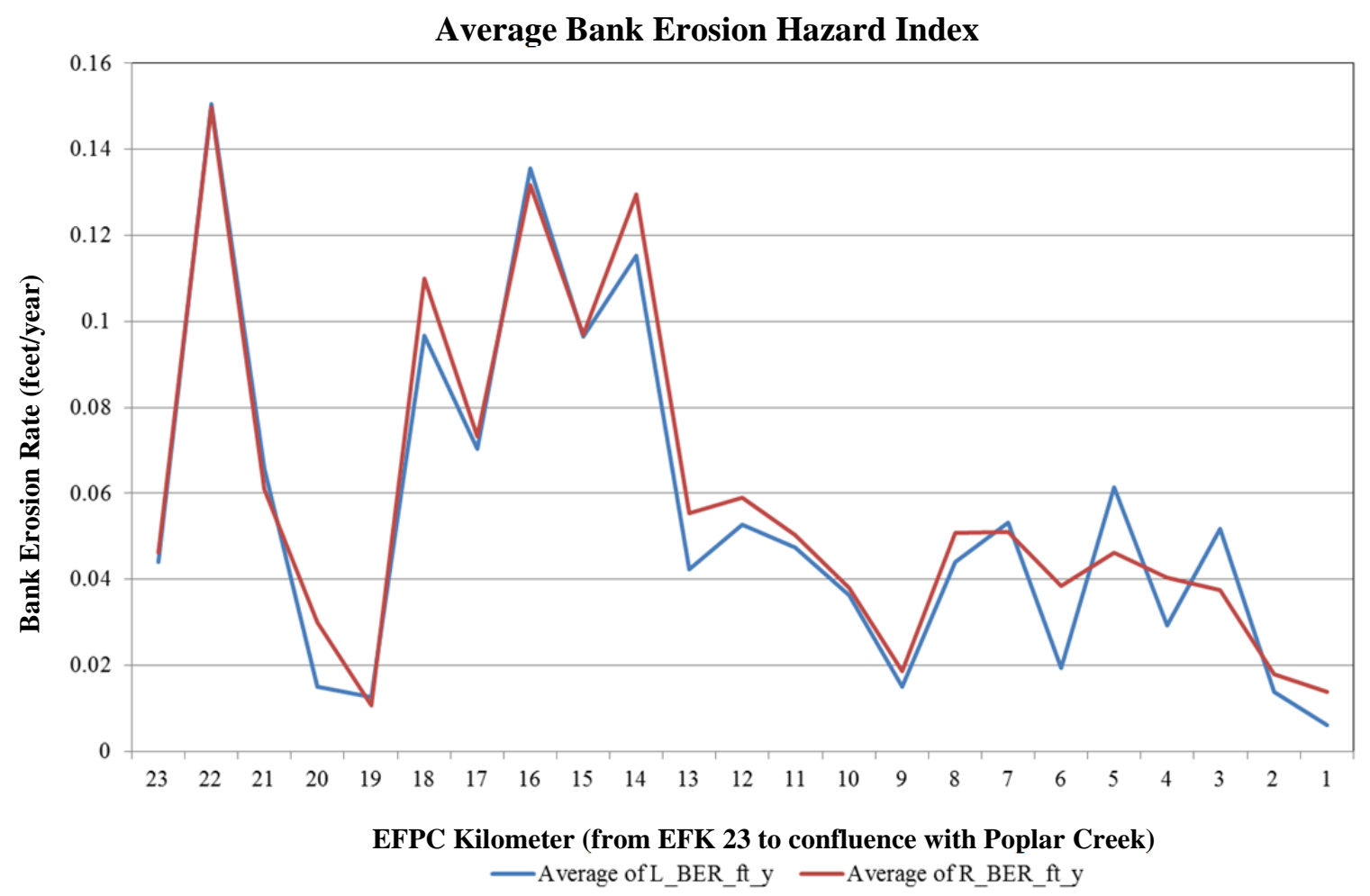

Fig. 10. Average bank erosion rate (BER) at 1 km intervals from East Fork Poplar Creek kilometer 23 to the confluence with Poplar Creek. 


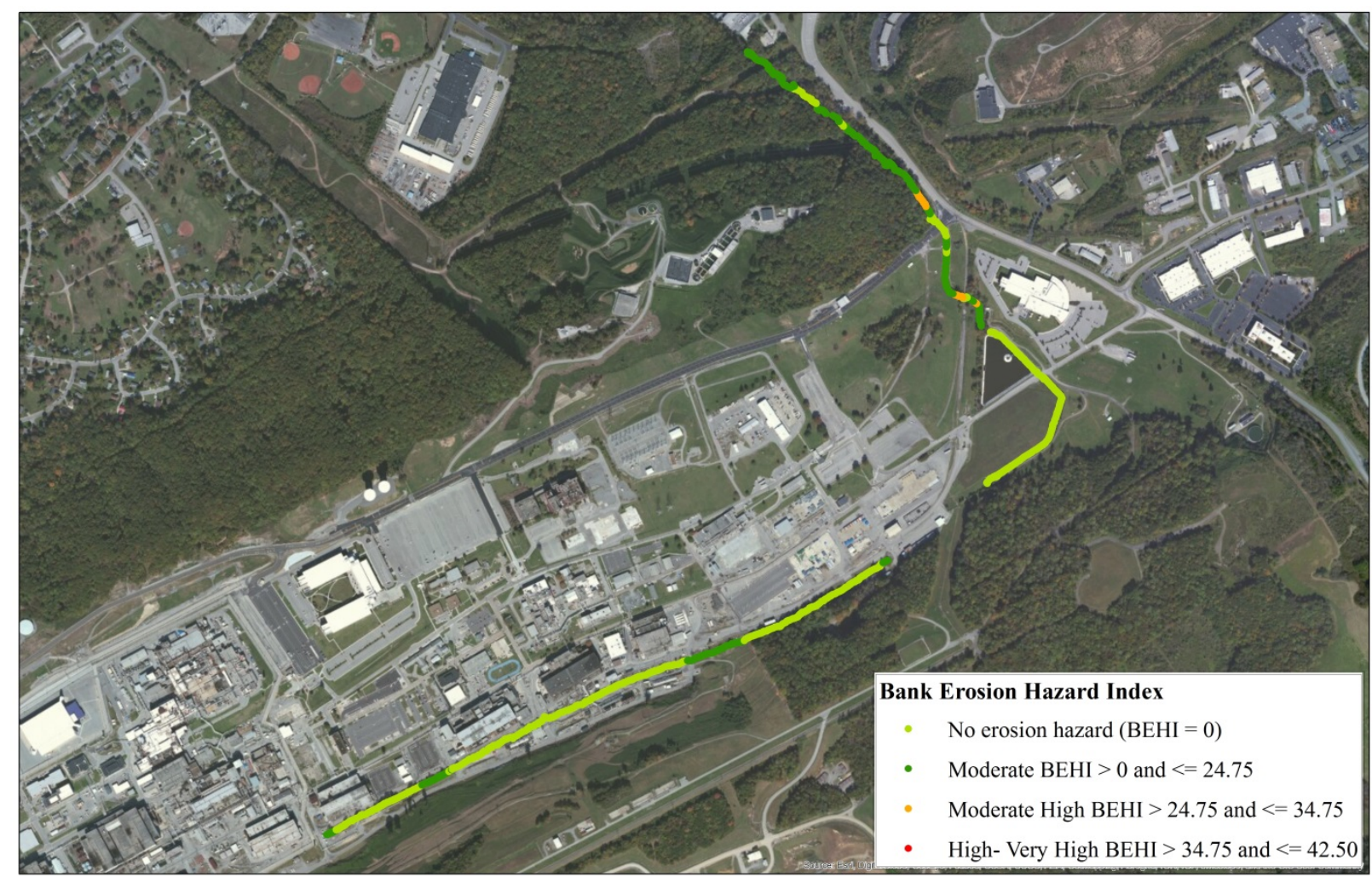

Fig. 11. BEHI values from the 2013 East Fork Poplar Creek stream bank video analysis.

The reach shown is approximately from Outfall 200 to East Fork Poplar Creek kilometer 23 (left to right).

Table 7. Summary statistics of bank erosion rate (BER; feet/year) and bank erosion hazard index (BEHI) from Outfall 200 to East Fork Poplar Creek kilometer 23

\begin{tabular}{lcccc}
\hline \multicolumn{1}{c}{ Statistic } & $\begin{array}{c}\text { Left bank } \\
\text { BER }\end{array}$ & $\begin{array}{c}\text { Right bank } \\
\text { BER }\end{array}$ & $\begin{array}{c}\text { Left bank } \\
\text { BEHI }\end{array}$ & $\begin{array}{c}\text { Right bank } \\
\text { BEHI }\end{array}$ \\
\hline Mean & 0.0096 & 0.0152 & 4.9587 & 5.8658 \\
Standard error & 0.0009 & 0.0013 & 0.1033 & 0.1195 \\
Median & 0 & 0 & 0 & 0 \\
Mode & 0 & 0 & 0 & 0 \\
Standard deviation & 0.0634 & 0.0885 & 7.0645 & 8.1753 \\
Minimum & 0 & 0 & 0 & 0 \\
Maximum & 0.7208 & 0.7208 & 22.25 & 28.3 \\
\hline
\end{tabular}


Histogram of Bank Erosion Rates

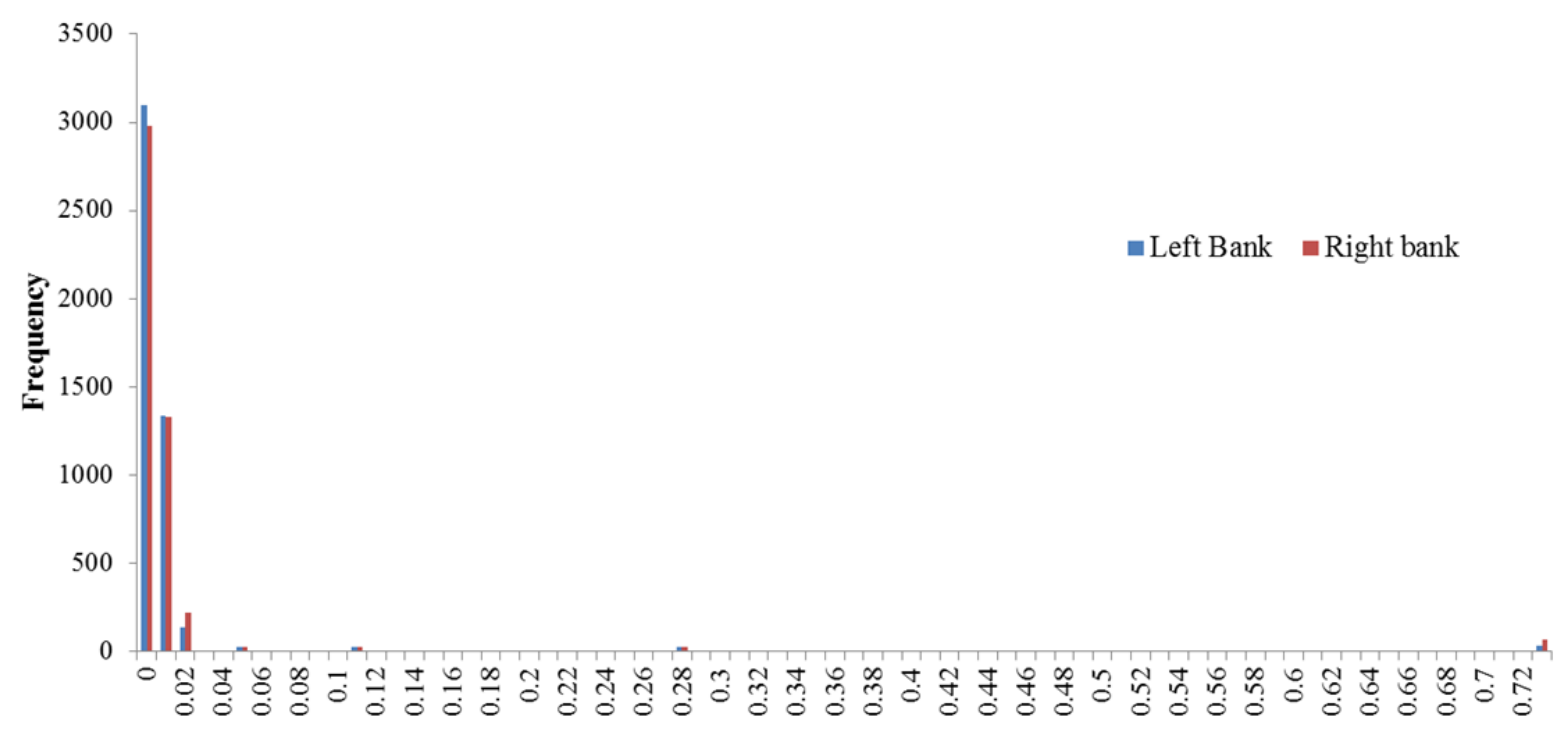

Bank Erosion Rate (ft/yr)

Fig. 12. Histogram of bank erosion rates of the left and right banks from Outfall 200 to East Fork Poplar Creek kilometer 23.

Erosion pins and bank soil sampling-Eight erosion pin sets were installed at seven sites along the creek in November 2013 (Appendix A). Two sets were installed close to one another at the farthest downstream site (EFK 5.4; Fig. 13). Two to three erosion pins were installed at each site along a vertical stream bank transect extending from near the water's edge to near the top of the stream bank. Where possible, a fixed vantage point was established on the opposite stream bank at each site from which photographs could be taken and readily compared over time. Bank profiles, recorded in July 2014, show the range of profiles studied (Fig. 14).

Over the course of the 531-day erosion pin deployment, net erosion was recorded for 15 of 19 pins (Fig. 15). Much of that erosion occurred during winter and early spring, with little to no erosion recorded from mid-spring to mid-summer. Several factors contribute to enhanced erosion during winter and early spring. There is little to no vegetative cover on stream banks during that time. Freeze-thaw cycles and frost heave are more likely to occur during that time. Wetter soils and lower evapotranspiration (ET) during winter through mid-spring favor increased runoff-rainfall ratios, meaning rainfall of similar magnitude will generate higher streamflow in winter than in summer. During the January 2014 sampling campaign, extensive ice lenses were observed beneath a very friable surface of $\sim 5 \mathrm{~mm}$ of bank soil (Fig. 16). Material slump brought on by frost heave and undercut by the flowing creek also was observed (Fig. 17). 


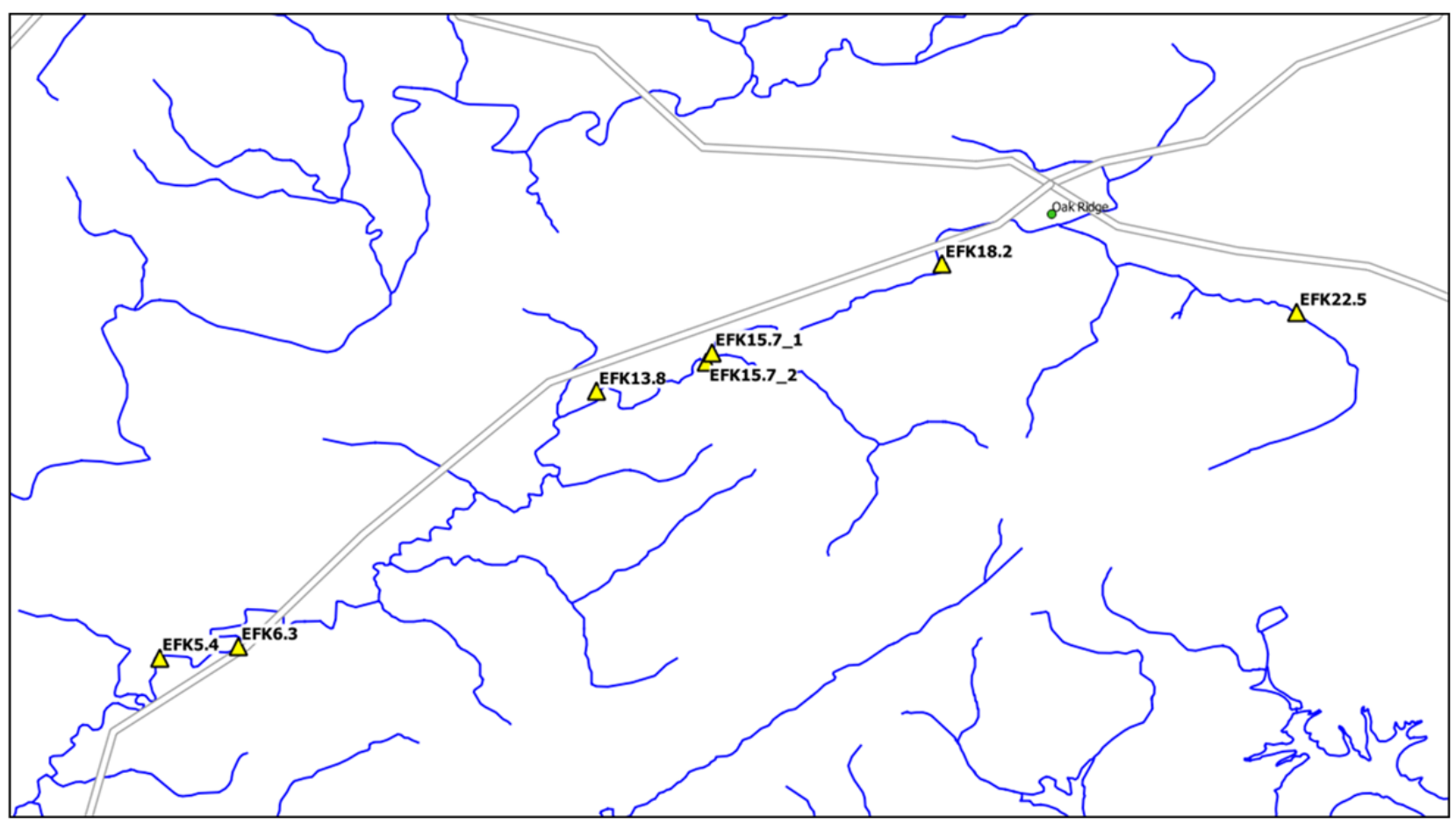

Fig. 13. Map of erosion pin sites on lower East Fork Poplar Creek. Two sets of pins were installed at East Fork Poplar Creek kilometer (EFK) 5.4. For site EFK 15.7, "1" and "2" refer to sites upstream and downstream, respectively, of the confluence of the Mill Branch tributary with EFPC.

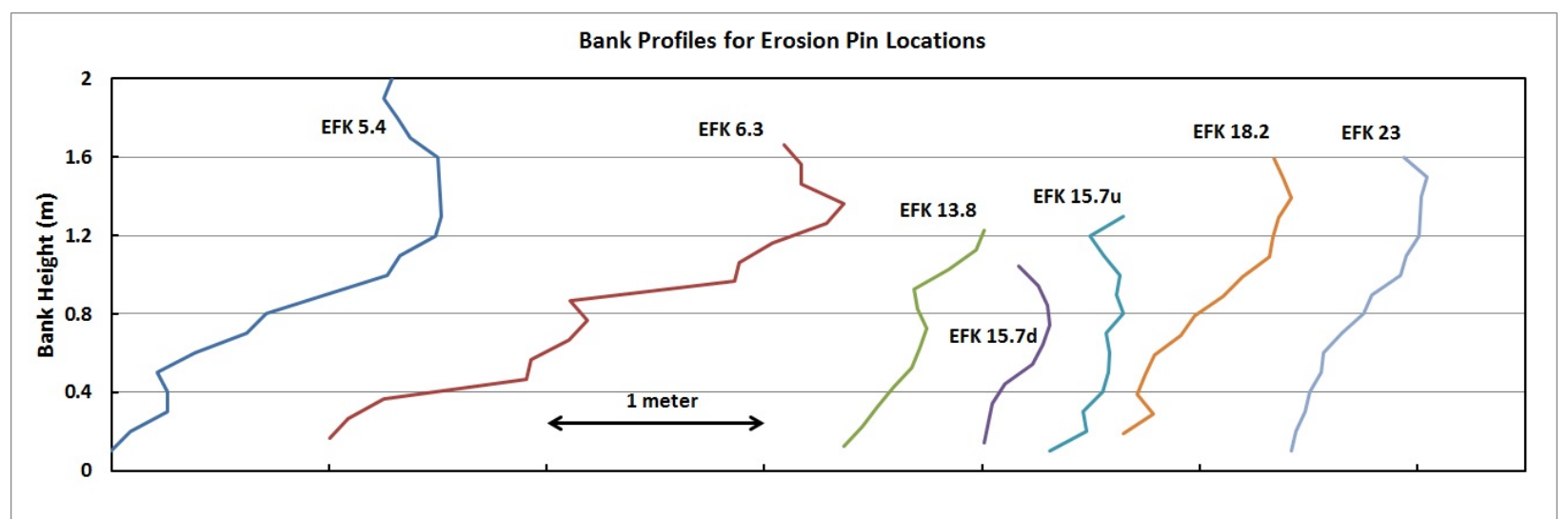

Fig. 14. Bank profiles of the sites where erosion pins were installed. The number designator after "EFK" for site names refers to the East Fork Poplar Creek kilometer, measured upstream from the mouth of the creek, to the site. For site EFK 15.7, "u" and "d" refer to sites upstream and downstream, respectively, of the confluence of the Mill Branch tributary with EFPC. 


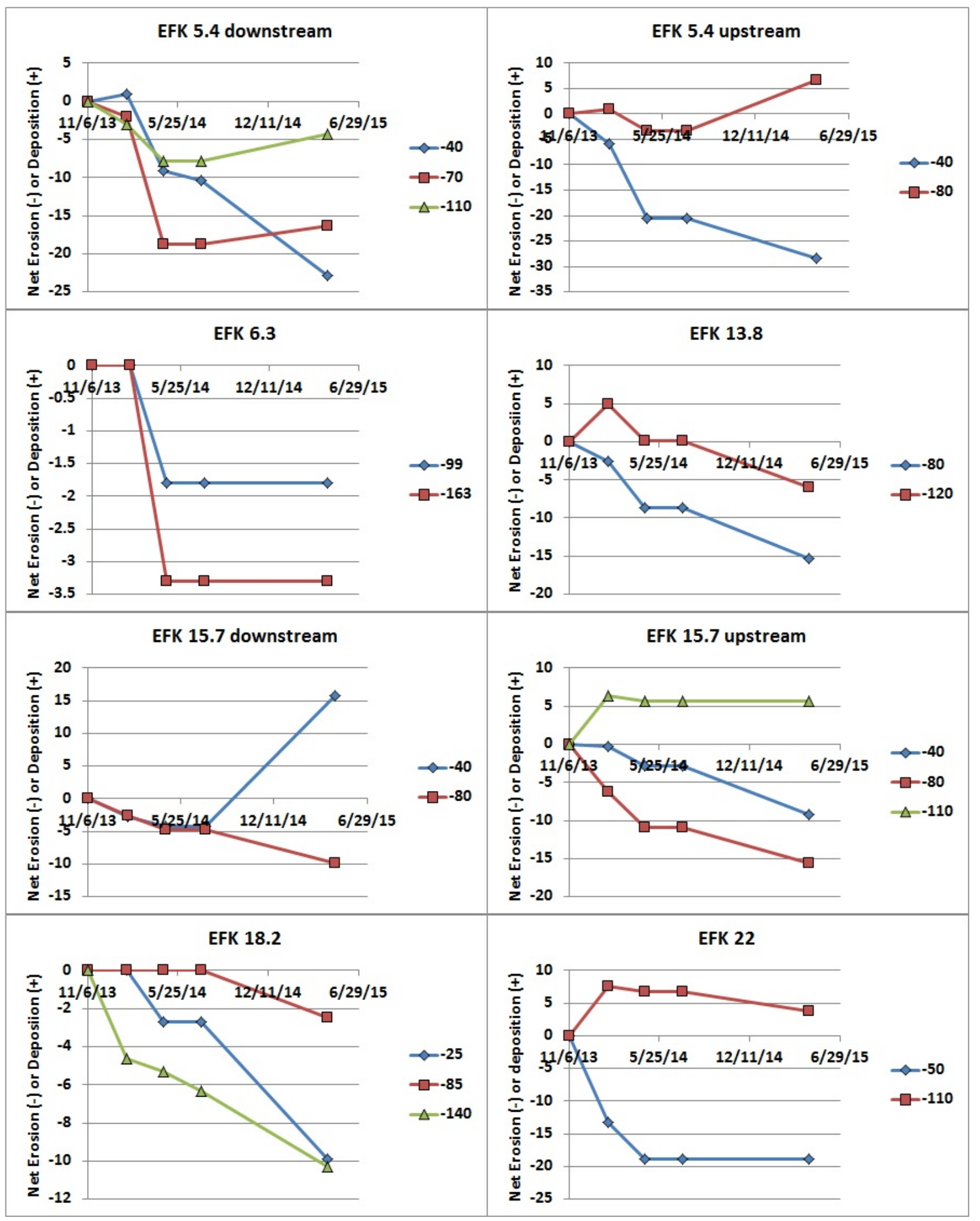

Fig. 15. Estimates of net erosion or deposition over time from erosion pin measurements at eight East Fork Poplar creek kilometer (EFK) sites. Numbers in the legend of each plot indicate the distance in centimeters to the erosion pin from the top of the creek bank. 




Fig. 16. Erosion pin and ice layers under the surface of creek bank soil at East Fork Poplar Creek kilometer 13.8. Photograph taken January 31, 2014.

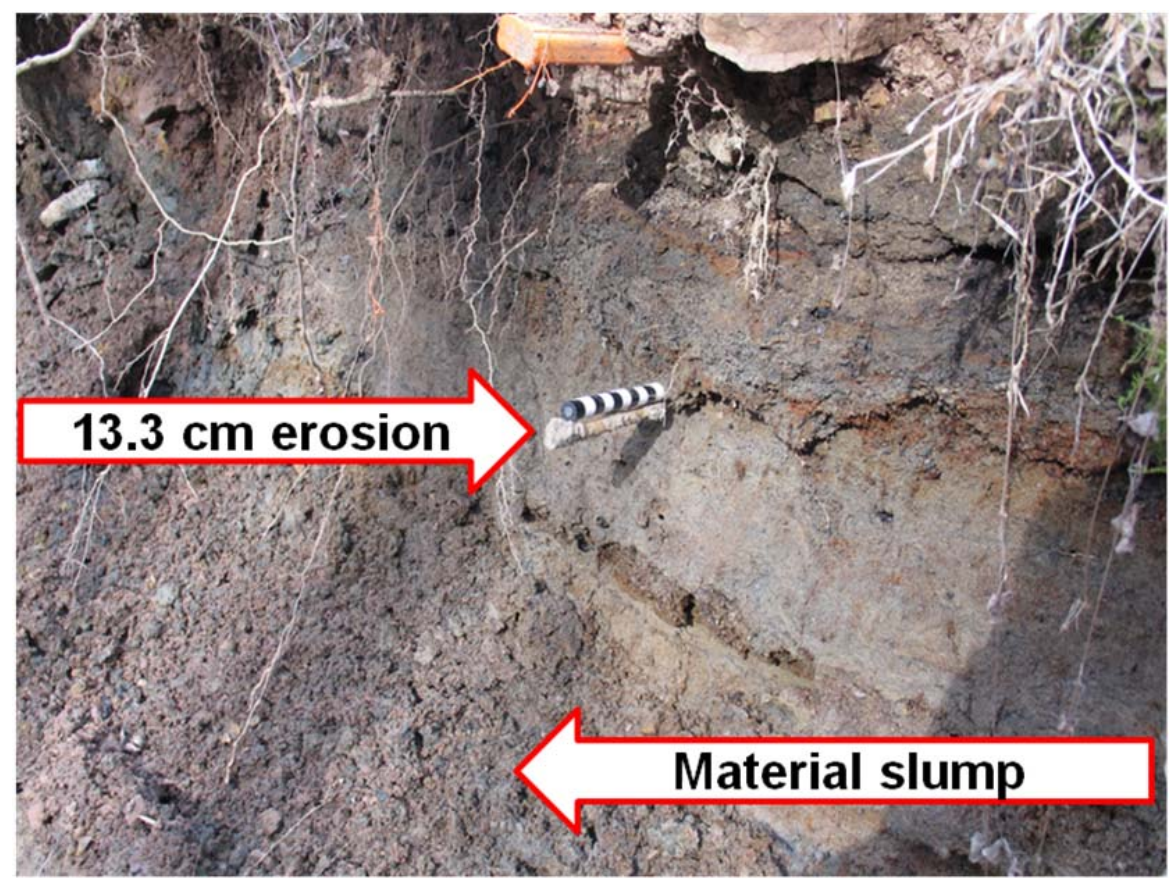

Fig. 17. Photograph of creek bank at East Fork Poplar Creek kilometer 22 on January 31, 2014, 96 days after erosion pin installation. The scale resting on the erosion pin is $10 \mathrm{~cm}$ long. The material that eroded away and exposed the erosion pin is seen at the bottom and is the result of a broad slump of material off the face of the creek bank. The $13.3 \mathrm{~cm}$ erosion recorded for the exposed pin was accompanied by $7.5 \mathrm{~cm}$ material deposition over the pin located $60 \mathrm{~cm}$ lower on the bank face (see Fig. 15). 
The total net erosion or deposition measured at each pin was divided by the duration of deployment to calculate BER based on these field measurements. The results are presented in units of feet per year to facilitate comparison with the kayak survey results presented previously. The overall BER ranged from $3.5 \mathrm{ft} /$ year (indicating net deposition) to $6.4 \mathrm{ft} /$ year with a median value of $1.7 \mathrm{ft} /$ year (Fig. 18). The BER values calculated from erosion pin measurements are on the order of 100 times greater than the values estimated from the kayak survey. This discrepancy is not surprising given that conversion of BEHI to BER in the kayak survey requires a number of untested assumptions and the use of rating curves that have not been calibrated for EFPC. Nevertheless, there was also poor correspondence between the BER derived from the erosion pins and the BEHI.

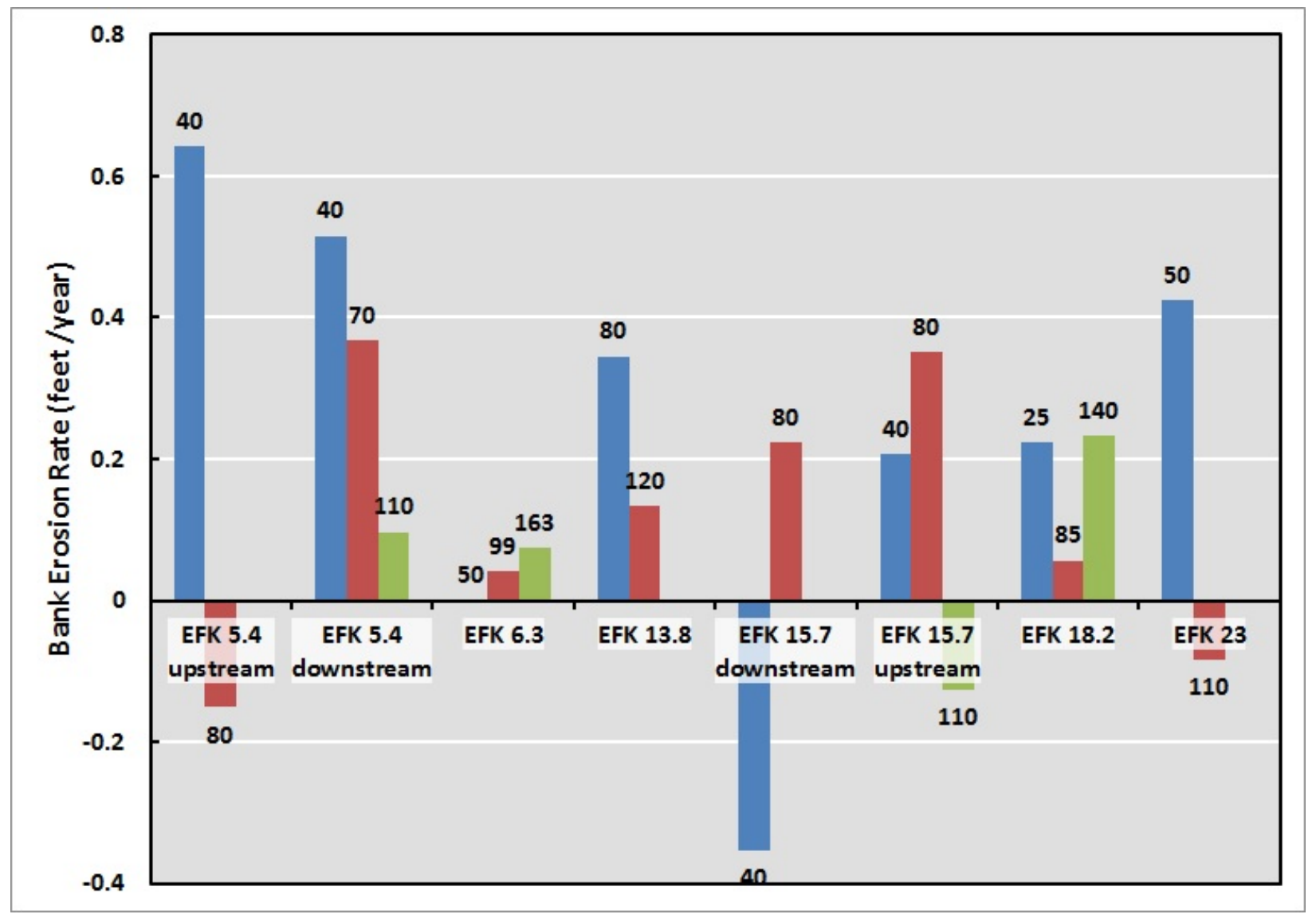

Fig. 18. Calculated bank erosion rate for erosion pins located at several East Fork Poplar Creek kilometer (EFK) sites. Negative values indicate net deposition. Numbers at the end of each bar indicate the pin location in centimeters from the top of the bank.

Comparison of BER from kayak survey to erosion pin measurement-The mean BER from the kayak survey for a $100 \mathrm{~m}$ reach centered on the erosion pin location was compared with the mean BER estimated from the erosion pins (Fig. 19). There was poor correspondence between these two methods, with the erosion pin measurements roughly 10 times greater than the kayak survey estimates. However, the number of points for comparison is small, and a better-behaved relationship between the methods may emerge with more measurement points. 


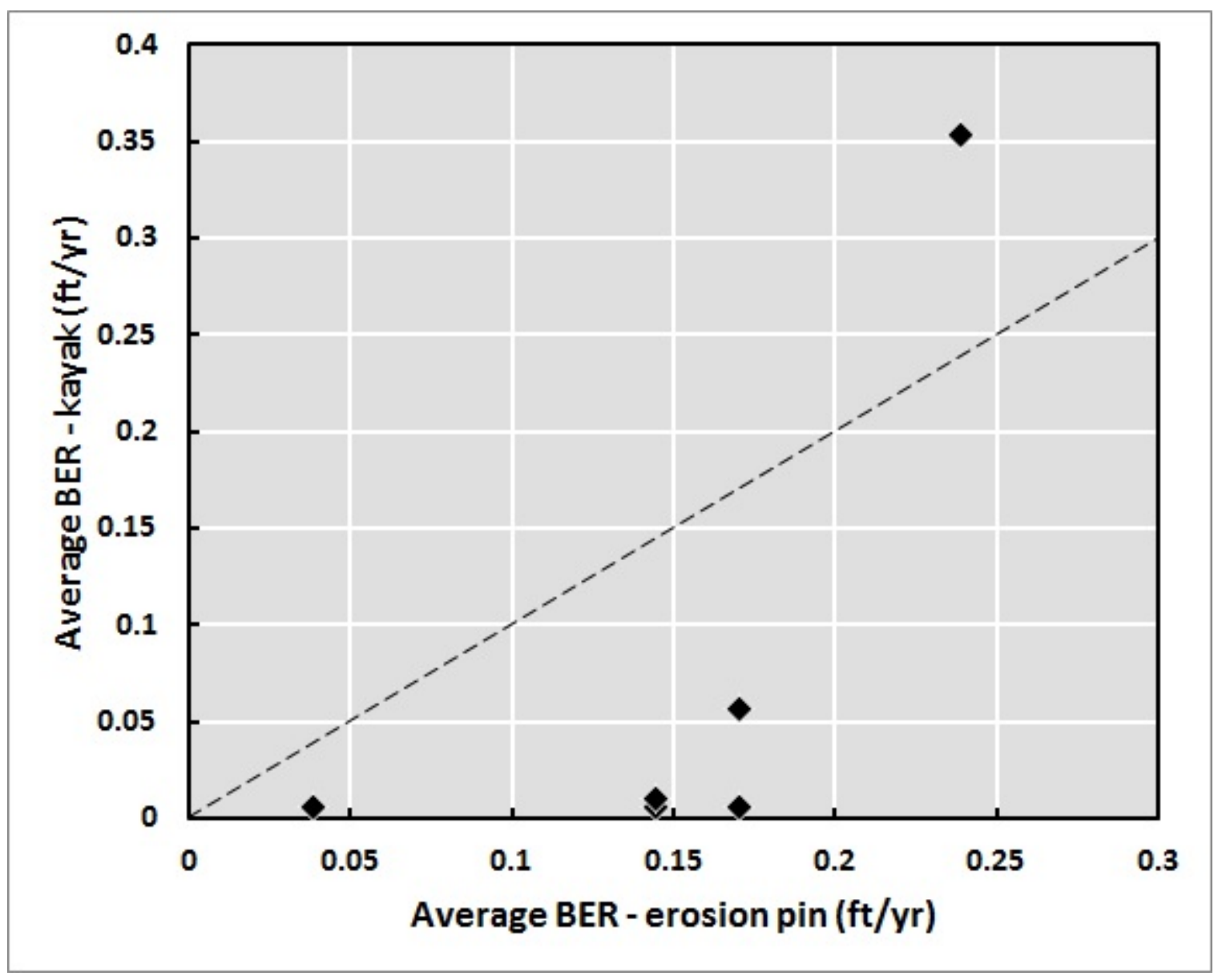

Fig. 19. Average bank erosion rate (BER) estimated from the kayak survey data versus average BER measured from the erosion pins. Dashed line indicates perfect agreement.

Mercury concentration in bank soils - Total mercury concentration in horizontal cores collected close to the erosion pins varied from 0.05 to $1,300 \mathrm{mg} / \mathrm{kg}$ dry weight (Fig. 20, Appendix A). Generally, mercury concentration decreased with increasing depth into the stream bank, although for several cores, concentration did not change or rose with increasing depth into the creek bank. Stream bank samples were collected on two occasions. Surface samples of $\sim 1$ in. were collected in January 2014, and horizontal cores were collected in April 2014. The January samples showed a general decrease in mercury concentration with longitudinal distance along the creek. However, in April, there was no consistent trend in mercury concentration with distance along the creek. Comparison of the January samples to the top 1 in. of the cores collected in April showed no correlation between mercury concentrations for the two sampling dates (data not shown). Such a large degree of both spatial and temporal heterogeneity in mercury concentration was unexpected. Although this complicates the attempt to estimate the magnitude of bank loading, it also may suggest that underneath a somewhat shallow veneer of contamination, the bank soils are relatively clean and are contaminated after erosional exposure via contact with mercury carried in the creek water.

At EFK 18.2, a dark layer with a more sandy texture was found approximately $50 \mathrm{~cm}$ below the top of the bank. Believing this to be a historical release deposit (HRD) previously described by Southworth et al. 
2011 , researchers collected a separate core of this material. Total mercury concentration was $\sim 1,000$ $\mathrm{mg} / \mathrm{kg}$ dry weight uniformly throughout the core (Fig. 20f). Microscopic examination of the material at low magnification showed both angular fragments resembling coal fines and distinct spheres of fly ash mixed in with ambient soil minerals (Fig. 21b). The material was characterized further with an electron microscope and energy dispersive x-ray spectroscopy for elemental mapping (Fig. 20c-f). The angular fragments and fly ash spheres as well as small grains of pyrite were evident under much higher magnification along with distinct mercury-rich precipitates consisting of mercury, sulfur, and iron (Fig. 21d). Mercury and sulfur also were present in the clay minerals of the soil matrix, albeit to a lower extent (Fig. 20e). The fly ash sphere was composed primarily of aluminum and silicon with no mercury present (Fig. 20f). The fly ash spheres present in the HRD sample were similar to a standard fly ash sample in both composition and morphology (not shown). 


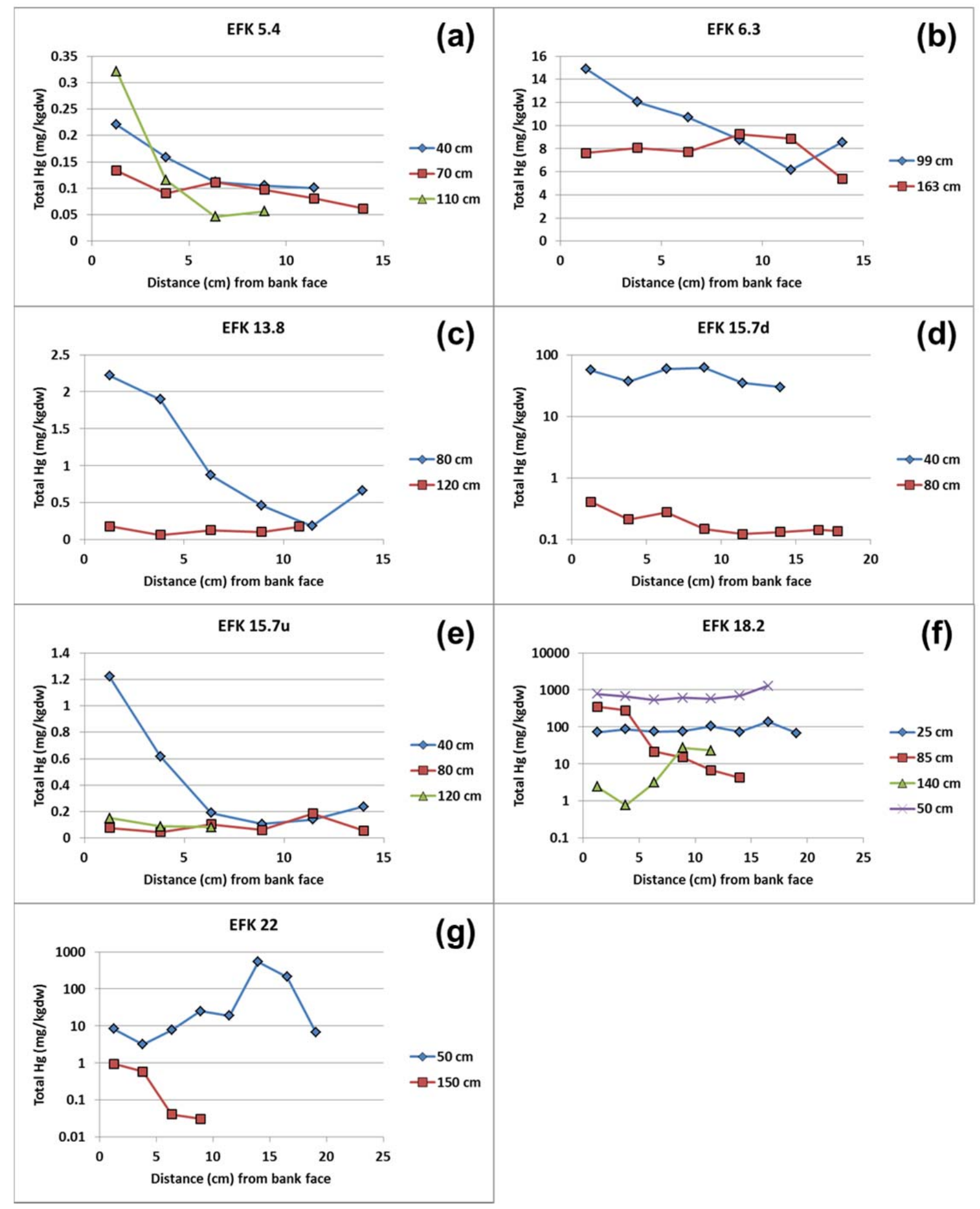

Fig. 20. Total mercury concentration in horizontal cores collected near the erosion pins on East Fork Poplar Creek in April 2014. The origin of the x-axis is the face of the stream bank. Numbers in the legend of each plot indicate the distance in centimeters to the coring spot from the top of the creek bank. Note the use of a $\log$ scale for the y-axis on panels (d), (f), and (g). In panel (f), the core collected $50 \mathrm{~cm}$ from the top was taken from the suspected historical release deposit. 

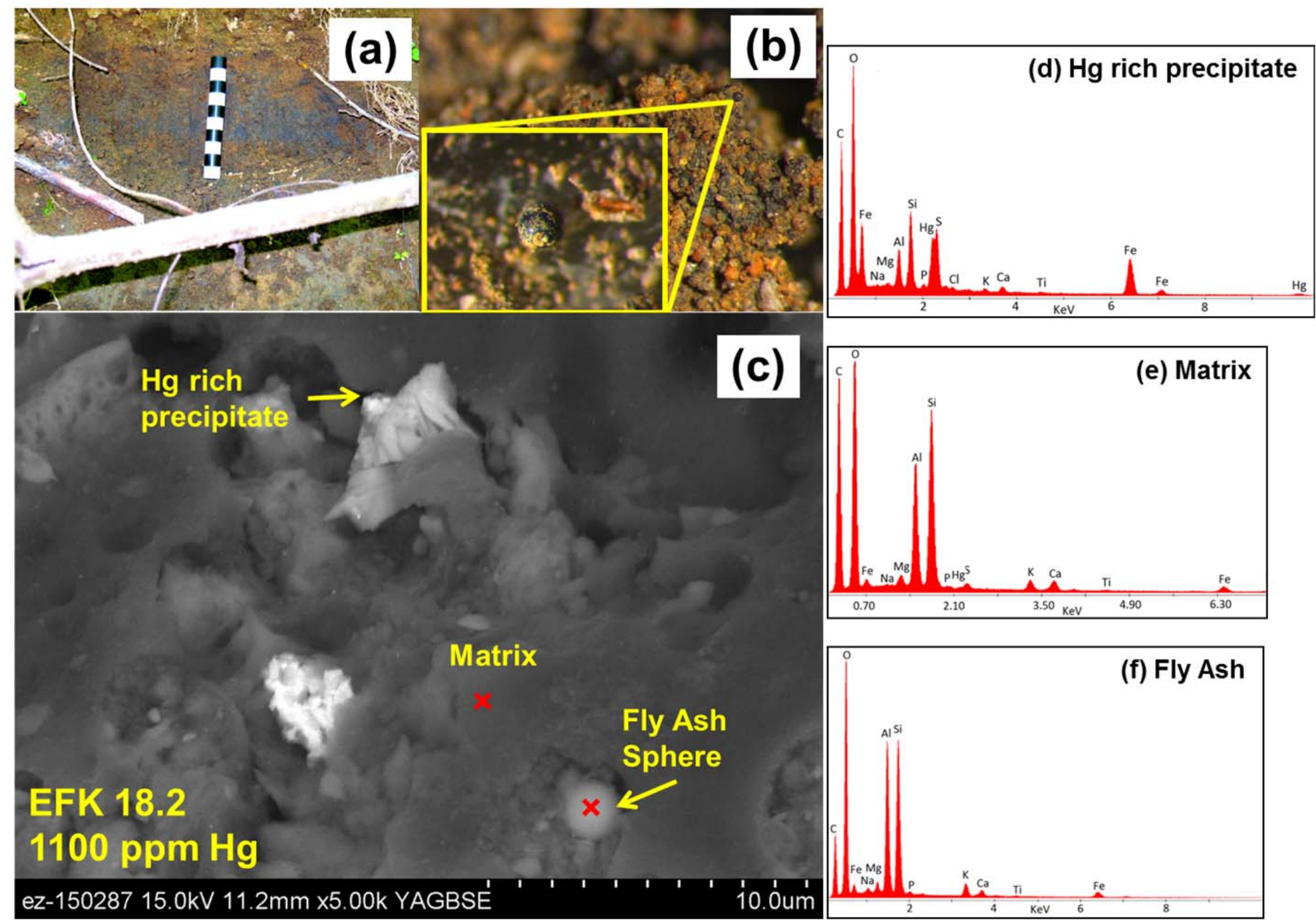

Fig. 21. (a) Photograph taken on April 23, 2014, of the historical release deposit (HRD) found at East Fork Poplar Creek kilometer (EFK) 18.2. The scale in the figure is $10 \mathrm{~cm}$. This figure is a contrast-enhanced version of the original digital photograph (Picasa v. 3.9.132) providing improved visibility of the layer.

(b) Photomicrograph of the HRD material under low magnification using a dissecting microscope. Inset in (b) shows a spherical particle found throughout the HRD sample. (c) Electron micrograph of the HRD material showing angular mercury-rich precipitate fragments and spherical fly ash particles. Scale at bottom right of the figure is $10 \mu \mathrm{m}$. (d-f) Energy dispersive x-ray spectroscopy analyses of the spots marked in panel (c) (Note: electron microscopy and energy dispersive x-ray work conducted by Dr. Debra Phillips, Queens University Belfast.) 
Estimates of mercury loading from bank erosion-Field activities and accompanying laboratory analyses provided estimates of BER and mercury concentration in bank soils. These were combined with recent measurements of bank soil bulk density $\left(1.2 \mathrm{~g} / \mathrm{cm}^{3}\right)$ (Dickson et al. 2015) to estimate mercury loading to the creek from bank erosion. BER estimates from erosion pin measurements were used in the calculations. Sites with no erosion or net deposition were assigned values of zero. Assuming that amount of lateral erosion, total mercury in eroded soils was calculated from the horizontal core data. Next, researchers assumed that value was representative of the vertical section centered on the erosion pin and then multiplied that value over a $100 \mathrm{~m}$ reach. The results for the horizontal layers were summed and multiplied by 2 to estimate total mercury loading from the left and right banks along that $100 \mathrm{~m}$ reach. Mercury loading estimates ranged from a low of $6 \mathrm{~g}$ mercury per $100 \mathrm{~m}$ per year $(\mathrm{g} \mathrm{Hg} / 100 \mathrm{~m}$ per year) at EFK 5.4 to a high of 5,900 g Hg/100 m per year at EFK 18.2, which included the HRD (Table 8). There is a great deal of uncertainty associated with these estimates because of the number of untested assumptions underlying the calculations, some of which are almost certainly wrong. For example, the research team's bank sampling activity showed a high degree of spatial and temporal variability in mercury bank soil concentration at a given location.

Table 8. Estimates of mercury loading from bank erosion at various East Fork Poplar Creek kilometer (EFK) sites

\begin{tabular}{lc}
\hline \multicolumn{1}{c}{ Location } & $\begin{array}{c}\text { Bank loading estimate } \\
\text { (g Hg/100 m per year) }\end{array}$ \\
\hline EFK 5.4 & 6 \\
EFK 6.3 & 35 \\
EFK 13.8 & 34 \\
EFK 15.7 $\mathrm{d}^{a}$ & 560 \\
EFK 15.7u ${ }^{a}$ & 9 \\
EFK 18.2 & 5,900 \\
EFK 23 & 310 \\
\hline${ }^{a}$ For site EFK 15.7, "u" and "d" refer to sites upstream \\
and downstream, respectively, of the confluence of the \\
Mill Branch tributary with EFPC.
\end{tabular}

Whereas there is clearly room for improvement in these estimates, they nevertheless provide an order-ofmagnitude indication of the role bank erosion may play in mercury loading to LEFPC. The presence of the HRD at EFK 18.2 dominates the mercury loading signal at that location and across all locations that were surveyed. A more thorough investigation of the extent and erosion rate(s) of the HRD is underway; this investigation will improve understanding of the role of this feature in mercury loading to the creek.

Most of these bank loading estimates can be expressed in grams of mercury per year. However, for the $100 \mathrm{~m}$ reach centered on EFK 18.2, mercury loading is approximated as nearly $6 \mathrm{~kg}$ mercury per year. This value is driven by the narrow HRD found at this site (Fig. 21 ), which constitutes $\sim 60 \%$ of the total load at this site. Recent discovery of a much thicker and more extensive HRD nearby suggests that 6 $\mathrm{kg} /$ year likely does not represent the maximum annual loading from creek banks. Regardless, even for the data in hand, a mercury loading of $6 \mathrm{~kg} / \mathrm{year}$ is on par with the waterborne mercury loading from Y-12 as measured at Station 17. In the most recent Remediation Effectiveness Report, waterborne mercury loading at Station 17 was estimated to be approximately $5 \mathrm{~kg} / \mathrm{year}$ (UCOR 2014). 


\subsubsection{Shallow Groundwater Connections to EFPC}

\section{Approach}

Shallow groundwater adjacent to EFPC may play a significant role in mercury cycling and dynamics in the creek, but this has gone largely uncharacterized to date. To address this compartment, several shallow piezometers were installed in the floodplain adjacent to the creek. Groundwater from these wells is sampled and analyzed for a suite of constituents including field parameters (water level, temperature, specific conductance, $\mathrm{pH}$, dissolved oxygen, and oxidation-reduction potential) and laboratory measurements (total dissolved $\mathrm{Hg}$ and $\mathrm{MeHg}$ ). Results of the groundwater analyses are compared with results for creek surface water collected at the same time.

\section{Results}

Researchers discussed several candidate floodplain sites and then made field visits. The final site selected for floodplain well installation was near EFK 15.7, adjacent to where the Mill Branch tributary enters EFPC. Four wells were installed at this location on July 2, 2013, by hand-driving 1 in. PVC casing to the point of refusal. After installation, each well was purged using a peristaltic pump until purge water was clear. Well locations and ground elevation subsequently were surveyed (Fig. 22). Well construction diagrams are referenced in Appendix A. Subsequent to well installation and development, groundwater and surface water were sampled for analysis in August 2013 and then were sampled monthly beginning in November 2013. The monitored water quality parameters are summarized in Table 9. Additional information on the groundwater analytical data collected for this project is referenced in Appendix A. The groundwater has a chemical composition that is both distinct from the surface water and consistent with active anaerobic microbial metabolism necessary for methylmercury production.

Water temperatures reflect a seasonal pattern, with warmer temperatures in the summer and colder temperatures in the winter (Fig. 23). As expected, the groundwater has a narrower temperature range, and temperatures lag behind the surface water.

Groundwater $\mathrm{pH}$ is consistently lower than the surface water, whereas the specific conductance is higher than the surface water (Fig. 24). The high specific conductance recorded for the surface water in February 2015 was due to road salt runoff. Microbial production of organic acids via anaerobic metabolism is likely responsible for both of these patterns.

Multiple other groundwater quality parameters are consistent with active microbial metabolism and specifically with anaerobic activity (Fig. 25). Dissolved oxygen and nitrate are largely absent from the groundwater, whereas dissolved ferrous iron (Fe[II]) is elevated in groundwater. Sulfate concentrations in groundwater are lower than those in the surface water. Field observations of a rotten egg odor from the wells are consistent with the presence of sulfide in the water samples. Additionally, dissolved manganese is elevated in the groundwater (data not shown).

Taken together, these results are consistent with the canonical progression of microbial terminal electronaccepting processes from aerobic metabolism, then consuming, in turn, nitrate, manganese (III/IV) oxides, ferric iron, and sulfate. Many of the known mercury methylating microorganisms are metal and sulfate-reducing bacteria. Therefore, the water chemistry results demonstrate the kind of microbial activity associated with mercury methylation.

Dissolved mercury concentrations were lower in groundwater than in surface water, but dissolved methylmercury $(\mathrm{MeHgD})$ concentrations were comparable to or up to 10 times greater than the surface water (Fig. 26a-b). Additionally, two of the wells, Mill Branch floodplain (MBFP)-03 and MBFP-04, 
showed a strong seasonal pattern in $\mathrm{MeHgD}$ concentration, with lower concentrations in winter and higher concentrations in summer, similar to the water temperature pattern. Surface water and water from wells MBFP-01 and MBFP-02 show a similar weak and insignificant temperature dependence. In contrast, $\mathrm{MeHgD}$ concentrations in MBFP-03 and MBFP-04 are relatively constant at temperatures below $\sim 12-15^{\circ} \mathrm{C}$ and exhibit steep increases above that temperature (Fig. $27 \mathrm{c}$ ).

Historically, one of the puzzling observations for EFPC has been the poor relationship between $\mathrm{Hg}$ and $\mathrm{MeHg}$ in the creek water. Surface water data collected for this study show no relationship between these two parameters. In contrast, the shallow groundwater shows a strong positive correlation between dissolved $\mathrm{Hg}$ and dissolved $\mathrm{MeHg}$ (Fig. 26d). Finally, the percent $\mathrm{MeHg}$, defined as the percent of total dissolved $\mathrm{Hg}$ that is $\mathrm{MeHg}$, is significantly higher in the groundwater relative to the surface water (Fig. 27).

During spring, summer, and autumn, the groundwater gradient slopes away from the creek toward inland well MBFP-04 (Fig. 28). This gradient is driven and maintained by ET during the active growing season. Decreased ET associated with plant senescence and leaf fall in autumn leads to a shallower and more variable gradient in terms of both magnitude and direction. The annual minimum in ET coupled with heavier precipitation in winter and early spring leads to gradient reversal where the water table slopes away from inland well MBFP-04 toward creekside wells MBFP-01, MBFP-02, and MBFP-03. This seasonal pattern in gradient indicates that the groundwater has the potential to discharge into EFPC in late autumn through early spring, whereas the opposite is true for the remainder of the year. It is important to note that these water level measurements support the potential for water exchange between the creek and shallow groundwater but are not sufficient evidence that such exchange actually occurs. Additional studies are required to establish whether groundwater-surface water exchange occurs and, if it occurs, to determine its timing, magnitude, and rate.

Sampling results to date strongly suggest that the shallow groundwater at the Mill Branch site supports methylmercury production. Although the dissolved mercury $(\mathrm{HgD})$ concentration is lower in groundwater than in surface water, MeHgD concentrations are comparable to or much greater than that in surface water, and the percent $\mathrm{MeHg}$ in groundwater is significantly greater than that in surface water. The temporal variability in groundwater chemistry, coupled with groundwater gradients, suggests water exchange with surface water is possible through a combination of lateral flow with the creek water and vertical recharge from precipitation. It is possible that the groundwater is a source of methylmercury to the surface water, but additional studies are required to establish the likelihood and magnitude of occurrence. 


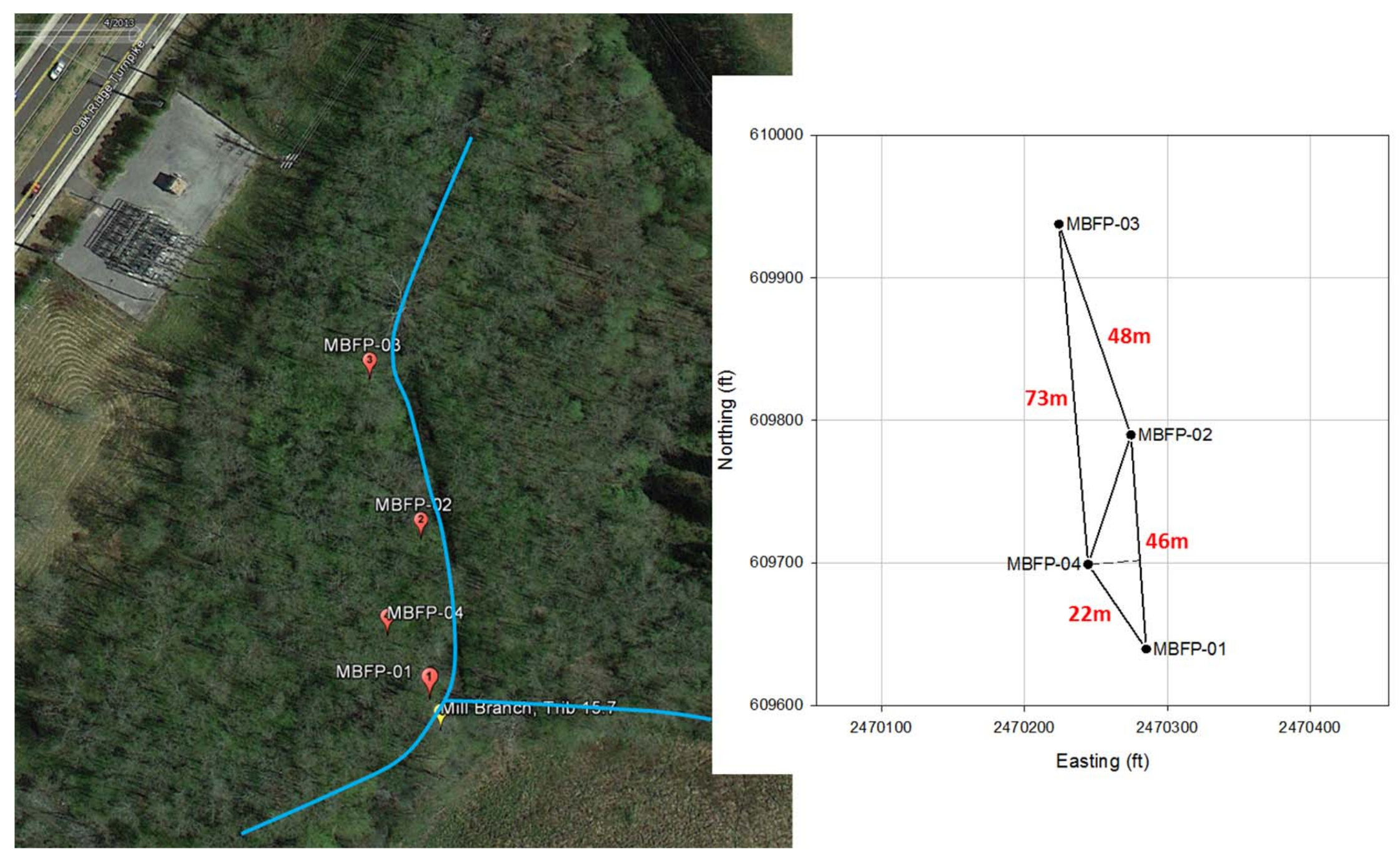

Fig. 22. Location of floodplain wells installed in the Mill Branch floodplain (MBFP) behind the Tennessee Valley Authority substation near East for Poplar Creek (EFPC) kilometer 15.7. The approximate locations of EFPC and Mill Branch have been drawn on the figure on the left (screen capture from Google Earth; aerial imagery date April 2013). Distance from top of the creek bank to wells MBFP-01, -02, and -03 is 1.2-1.5 meters; well MBFP-04 is $\sim 12.5$ meters from the creek. 
Table 9. Water quality parameters monitored in surface and groundwater

\begin{tabular}{ll}
\hline \multicolumn{1}{c}{ Measurement type } & \multicolumn{1}{c}{ Parameter } \\
\hline \multirow{3}{*}{ Field measurements } & Temperature, specific conductance, $\mathrm{pH}$, dissolved \\
& oxygen, oxidation-reduction potential, groundwater \\
& level \\
& Total dissolved metals (inductively coupled plasma \\
& mass spectrometry), chloride, nitrate, sulfate, total \\
& dissolved sulfide, ammonium, soluble reactive \\
& phosphorous, Fe(II), dissolved organic carbon, total \\
& mercury $(\mathrm{Hg})$ and methylmercury (MeHg) ${ }^{a}$, total \\
Laboratory measurements & dissolved $\mathrm{Hg}$ and $\mathrm{MeHg}$, total suspended solids \\
\end{tabular}

Note: Dissolved concentrations are operationally defined as anything passing a $0.2 \mu \mathrm{m}$ pore size filter.

${ }^{a}$ Total $\mathrm{Hg}$ and $\mathrm{MeHg}$ and total suspended solids were determined for surface water only.

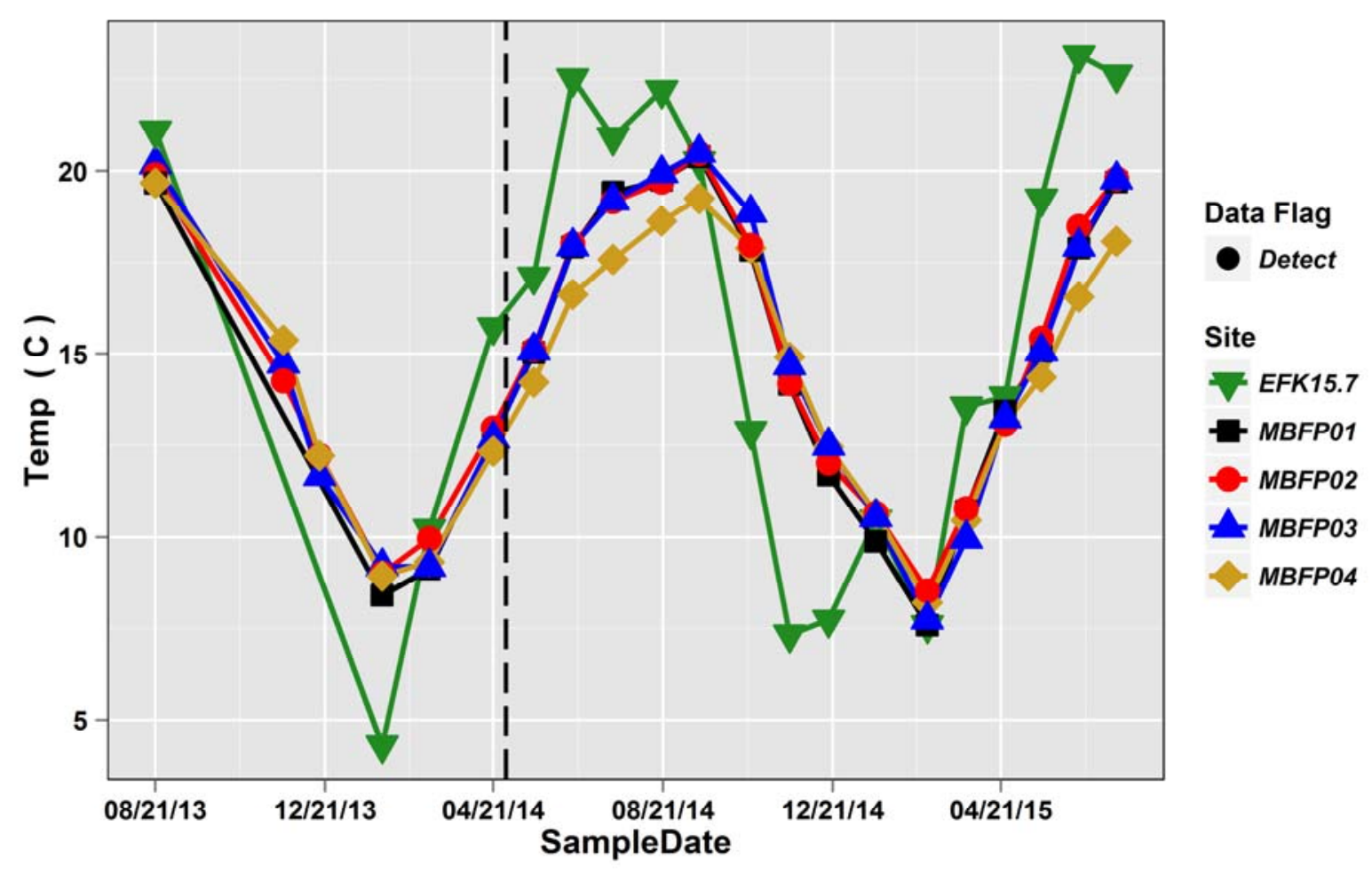

Fig. 23. Temperatures for surface water and groundwater at the East Fork Poplar Creek kilometer (EFK) 15.7 well cluster (Mill Branch floodplain [MBFP]-01 to MBFP-04). The vertical dashed line indicates the cessation of flow augmentation near Outfall 200 inside the Y-12 National Security Complex. 

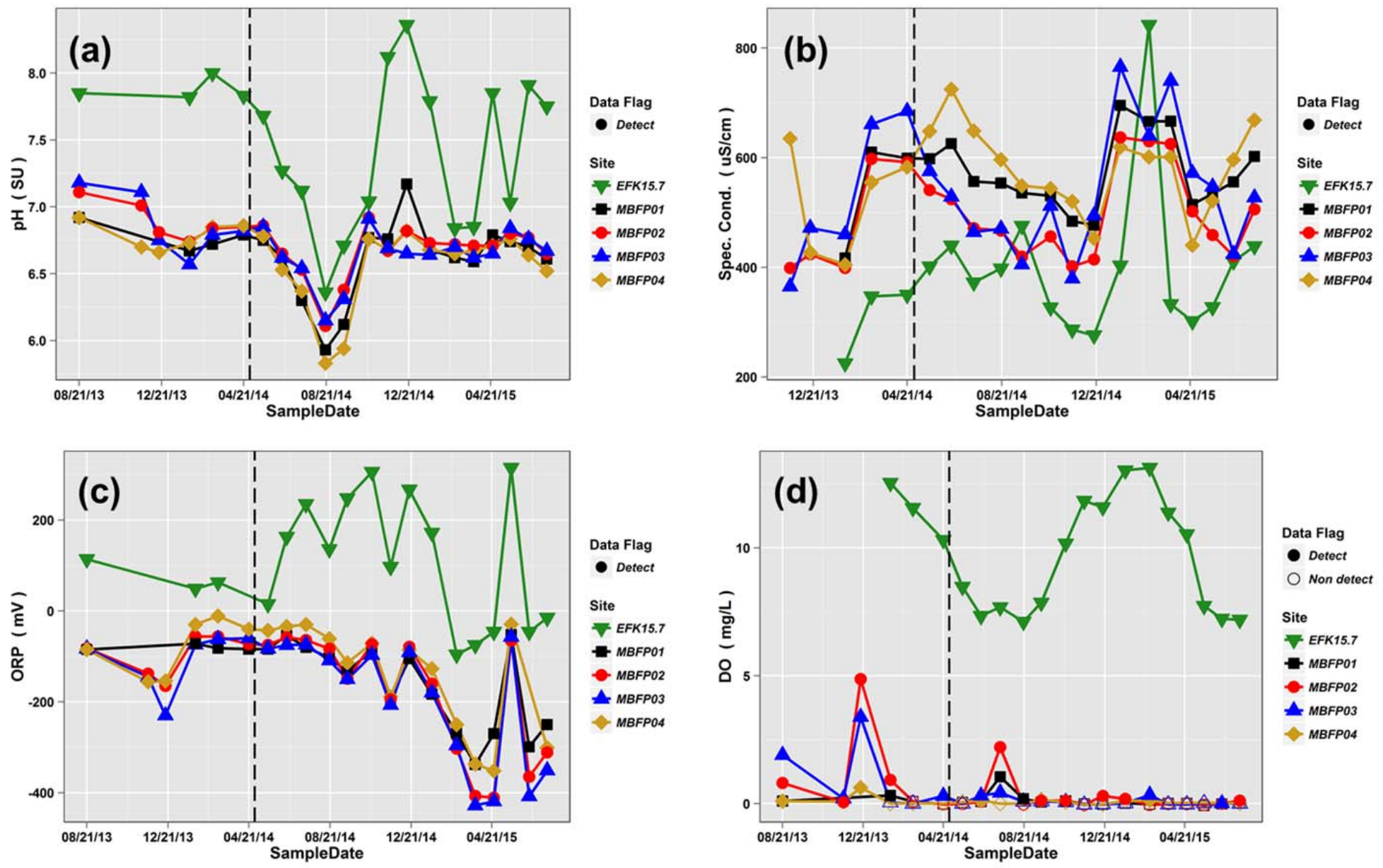

Fig. 24. Panels indicate (a) pH, (b) specific conductance (Spec. Cond.), (c) dissolved oxygen (DO), and (d) oxidation-reduction potential (ORP) for surface water (East Fork Poplar Creek kilometer [EFK] 15.7) and groundwater (MBFP-01 to MBFP-04). Open symbols indicate a value less than the analytical reporting limit. The vertical dashed line on each panel indicates the cessation of flow augmentation near Outfall 200 inside the Y-12 National Security Complex. 

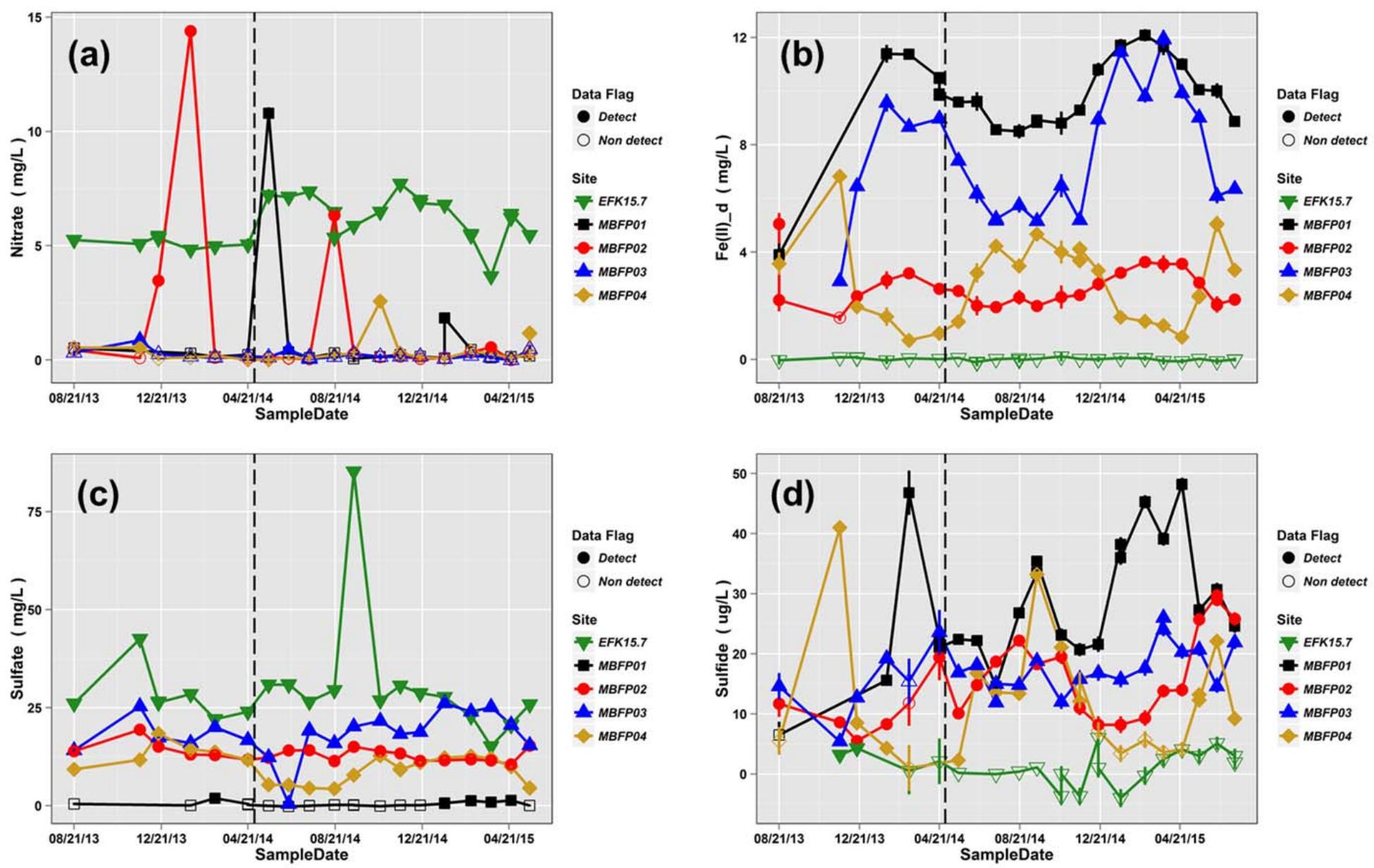

Fig. 25. Dissolved ( $<0.2 \mu \mathrm{m}$ ) concentrations of (a) nitrate, (b) ferrous iron, (c) sulfate, and (d) sulfide for surface water (East Fork Poplar Creek kilometer [EFK] 15.7) and groundwater (Mill Branch floodplain [MBFP]-01 to MBFP-04). Open symbols indicate a value less than the analytical reporting limit. Error bars indicate \pm 1 standard error of the analytical result. The vertical dashed line on each panel indicates the cessation of flow augmentation near Outfall 200 inside the Y-12 National Security Complex. 

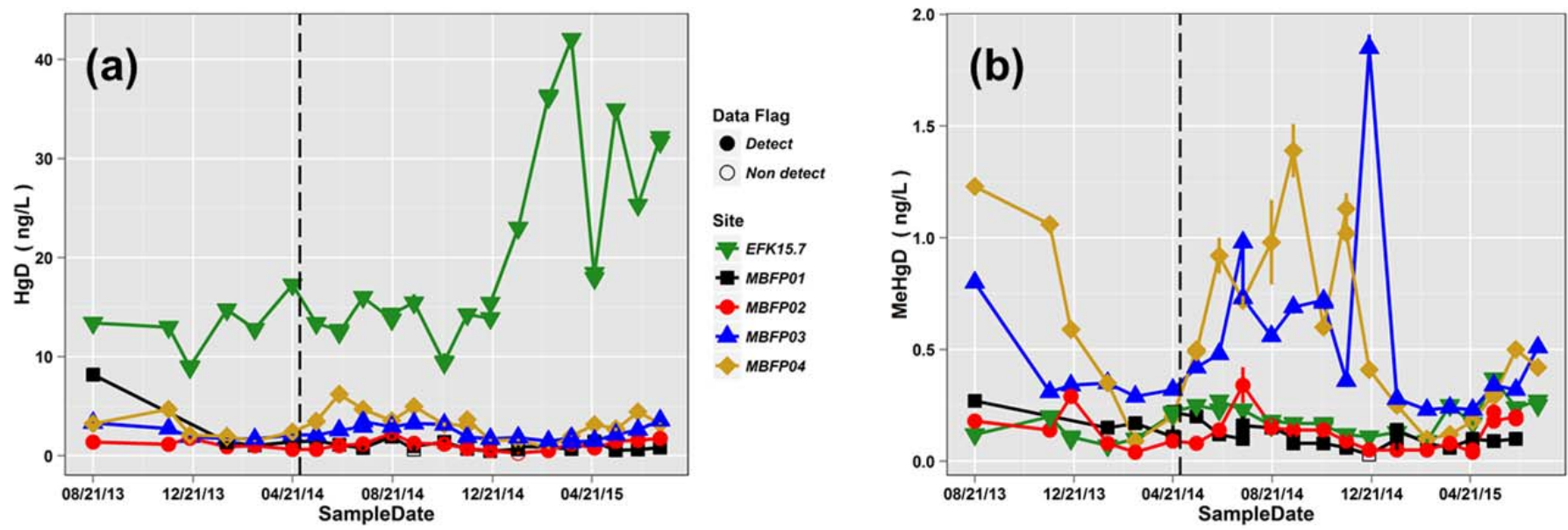

Data Flag

Data Flag

- Detect

Site

Site
₹ EFK15.7

$\rightarrow$ MBFP01

- MBFPO2

$\triangle{ }_{M B F P O}$

MBFP04
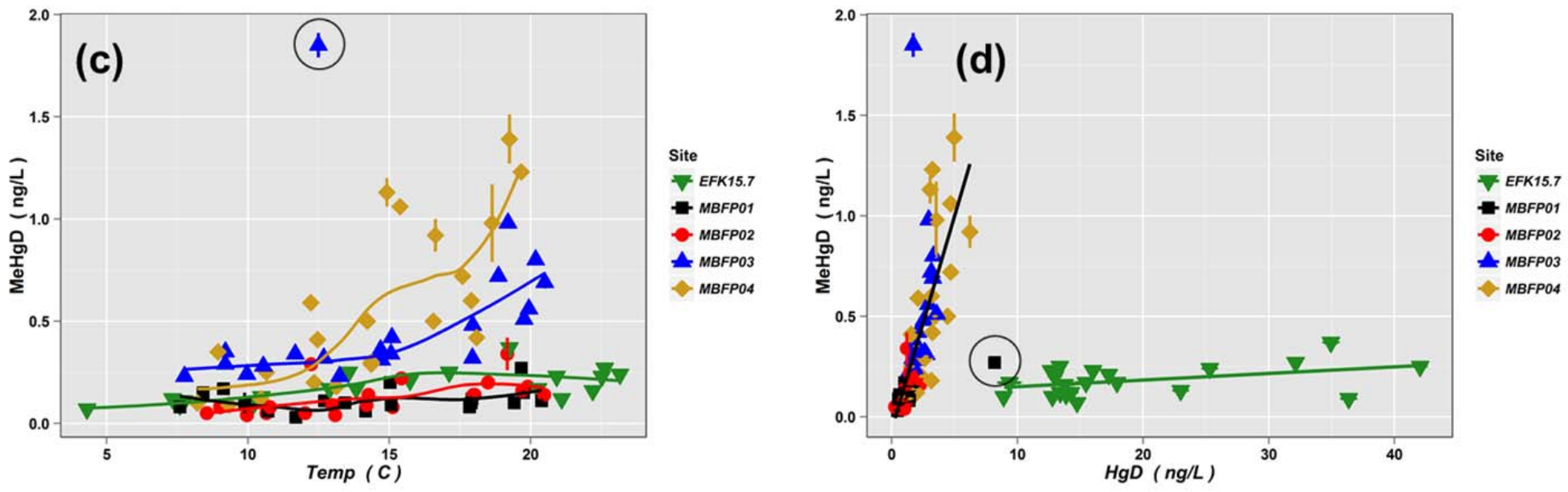

Fig. 26. Concentrations of dissolved (a) mercury (HgD) and (b) methylmercury (MeHgD) in surface water (East Fork Poplar Creek kilometer [EFK] 15.7) and groundwater (Mill Branch floodplain [MBFP]-01 to MBFP-04). The vertical dashed line in panels (a) and (b) indicates the cessation of flow augmentation near Outfall 200 inside the Y-12 National Security Complex. (c) Relationship between MeHgD and water temperature; the LOESS, or local regression, curve for each sample site is shown to help visualize the data. (d) Relationship between MeHgD and $\mathrm{HgD}$; the line through the well water samples is $\mathrm{y}=0.21 \mathrm{x}-0.06(p<<0.001)$, and the line through the surface water data is $\mathrm{y}=0.003 \mathrm{x}+0.12(p=0.055)$. The circled data points in (c) and (d) are outliers omitted from the smoothing or regression analysis. 


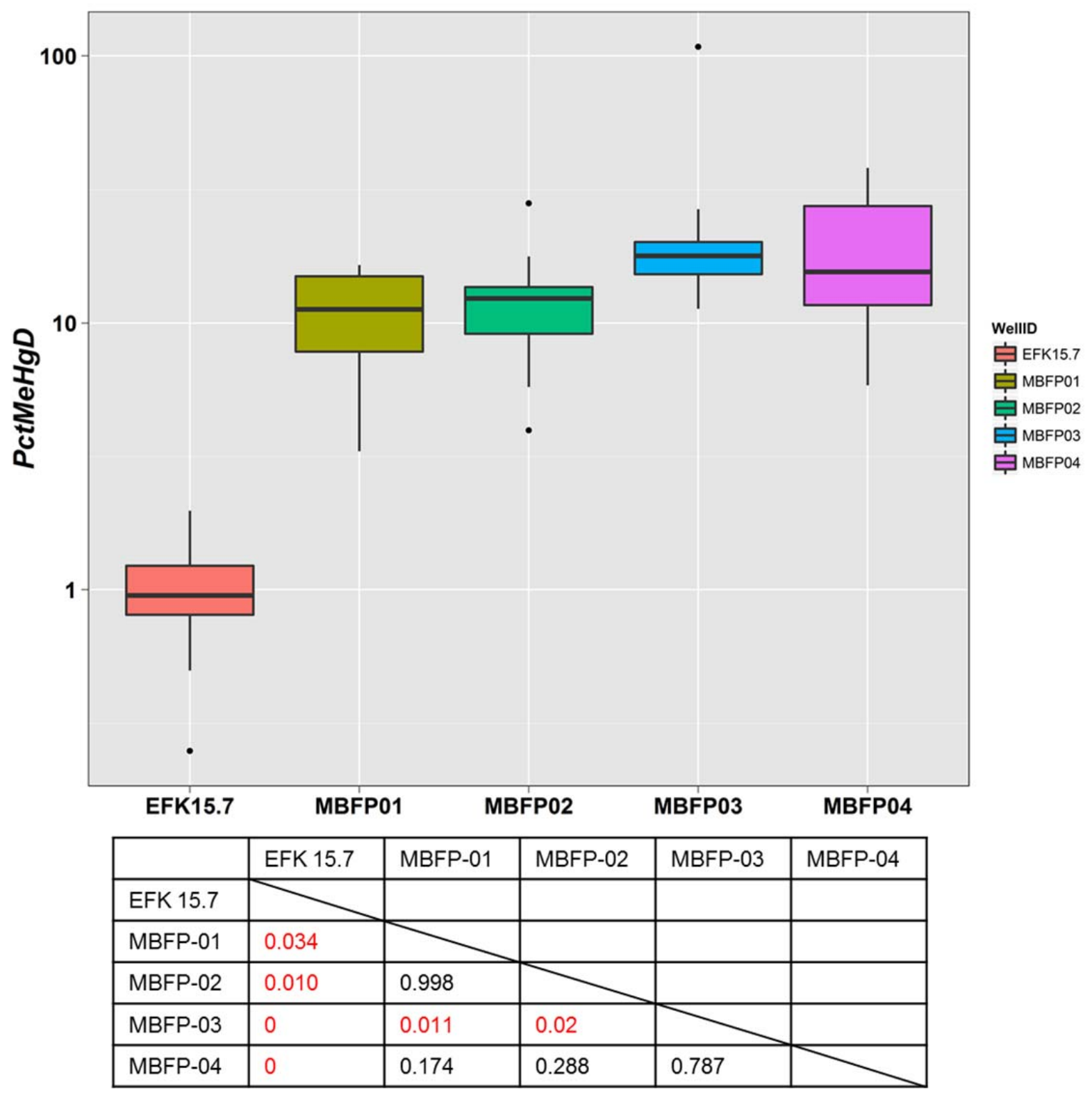

Fig. 27. Box-and-whisker plot of the percent dissolved methylmercury (MeHg) $(=100 \times \mathrm{MeHgD} / \mathrm{HgD})$ for surface water (East Fork Poplar Creek kilometer [EFK] 15.7) and shallow groundwater (Mill Branch floodplain [MBFP] wells MBFP-01 to MBFP-04). The limits of each box represent the interquartile range (extends from the 25th to the 75th percentiles), and the line inside each box represents the median. The whiskers start from the edge of the box and extend to the furthest data point that is within 1.5 times the interquartile range. Points outside the whiskers are shown by individual dots. The table below the figure shows the adjusted $p$ value for differences between the indicated well pairs based on Tukey's Honestly Significant Differences test. Values in red are significant at the 0.05 level. 


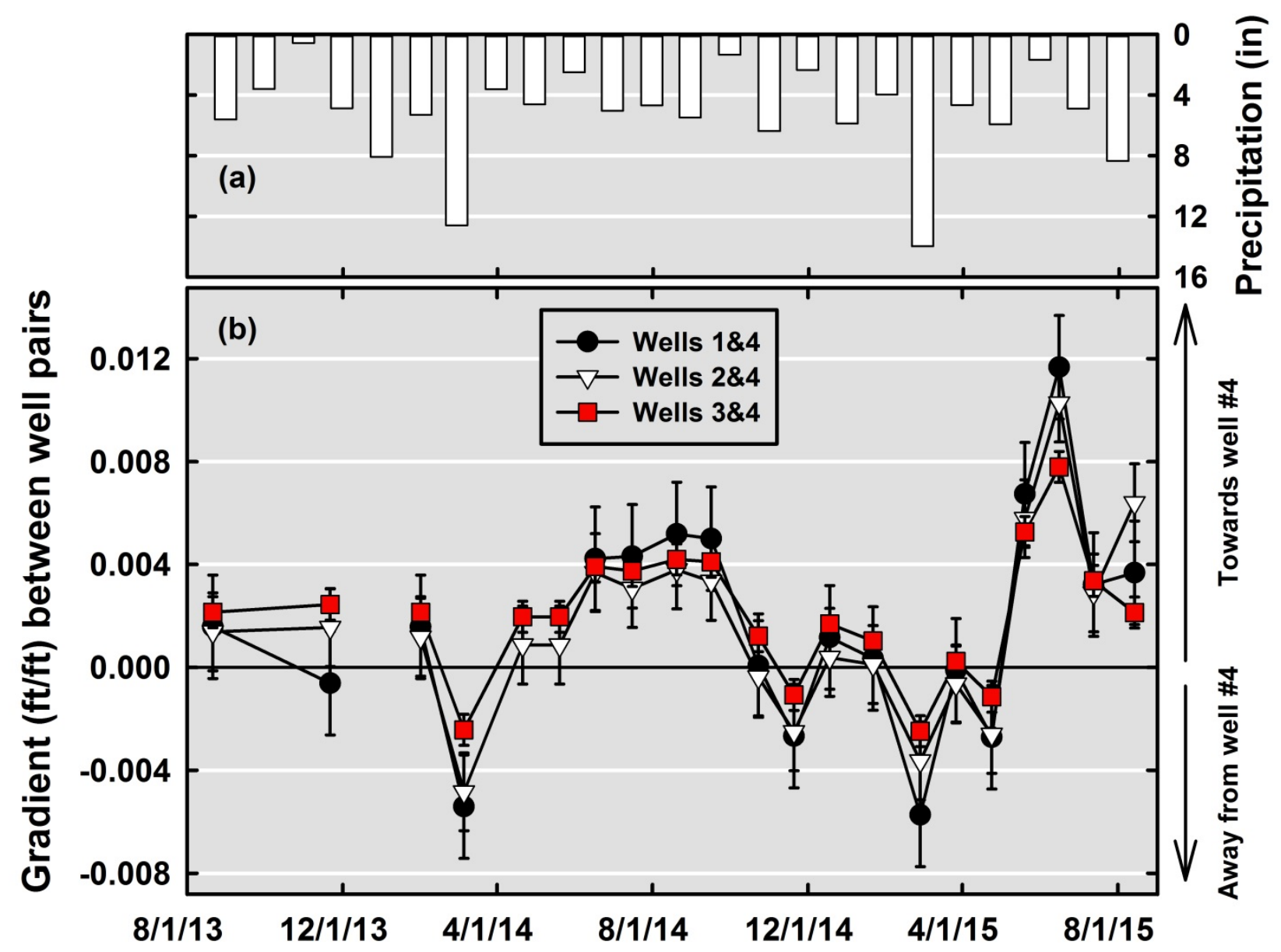

Fig. 28. (a) Total monthly precipitation (rain and snow) over the period of observation, and (b) water table gradient between creek bank wells 1, 2, and 3 and inland well number 4 . Positive values indicate the gradient is toward inland well number 4; negative values indicate the gradient slopes away from well \#4 toward the creek. Error bars indicate the estimated confidence band around the calculated gradient.

\subsubsection{Discussion of Field Studies}

Several activities were undertaken to better understand creek banks as a source of mercury loading to EFPC and to quantify mercury dynamics in shallow groundwater adjacent to the creek. These activities included high-resolution geospatial mapping of creek characteristics using kayak-mounted video and visual interpretation of the images to estimate BEHI and BER. Coupled with those video surveys, erosion pins were established at select locations to provide physical measurements of erosion. Seven locations were chosen along 18 creek kilometers based on initial interpretation of the video survey. Additionally, bank soil samples were collected at locations close to the erosion pins for quantification of total mercury in soil. These results were combined to make an order-of-magnitude estimate of mercury loading to the creek resulting from bank erosion. Finally, a set of shallow groundwater wells was installed near EFK 15.7 for routine sampling of groundwater to address possible formation of $\mathrm{MeHg}$ in groundwater and its export to the surface water.

The kayak-based survey provided information on creek bank characteristics for the entire length of the creek at unprecedented resolution. The information collected over the course of a few days would have taken many months of dedicated effort to collect by physical surveys. Researchers now have BEHI for 52 $\mathrm{km}$ of creek bank. Those BEHI values were coupled with a number of assumptions and rating values from 
other systems to estimate BER. The poor correspondence between the kayak-based BER estimates and those measured from erosion pins is not surprising given these assumptions. Nevertheless, the BEHI values can be used to guide targeted studies to evaluate local mercury concentration in bank soils coupled with ground-truthing measurements of erosion rates. It still may be possible to use the kayak-derived BEHI data to better estimate BER if the appropriate underlying rating functions are calibrated for EFPC.

Erosion pin measurements and mercury concentration in bank soils were used to make an order-ofmagnitude estimate of mercury loading from bank erosion for regions around the erosion pins. Many improvements can be made to these calculations, but the results indicate that bank loading in some locations is on par with waterborne mercury loading from Y-12. As operational practices within Y-12 continue to improve the water quality exiting the site, bank soils may come to dominate mercury loading to the creek.

Methylmercury was found in shallow groundwater adjacent to the creek at concentrations comparable to or much greater than concentrations in the surface water. The MeHg concentration increases during the spring, is highest during summer and early autumn, and then declines during late autumn, reaching an annual minimum during winter. Patterns in $\mathrm{MeHg}$ concentration and other water quality parameters strongly suggest in situ formation of $\mathrm{MeHg}$ in the groundwater driven by anaerobic microbial activity. The reason for the decline in $\mathrm{MeHg}$ concentration is not understood at this time. Dilution caused by increased precipitation and decreased ET may be one contributing factor. Additionally, seasonal changes to the water table gradient support the potential for $\mathrm{MeHg}$ created during the summer to be exported to surface water during late autumn and through the winter. Additional investigations are needed to identify if such an exchange actually takes place and its magnitude to determine if groundwater is a source of $\mathrm{MeHg}$ to the surface water.

\subsection{LABORATORY STUDIES}

Previous studies have examined the inventory of mercury in different environmental compartments in EFPC and have shown that contaminated soils and sediments downstream account for $>80 \%$ of the annual export of mercury from the entire watershed, with most export occurring during wet weather events (Southworth et al. 2013). Of the different compartments, stream banks susceptible to erosion and streambed particulates susceptible to resuspension during storm events were found to be the major sources of mercury maintaining high annual export rates. These findings imply that to prevent waterborne mercury contamination in this system from continuing for decades, management actions will have to control both the headwater mercury source that sustains elevated daily base flow mercury concentrations and the riparian stream bank sources that generate most of the mercury export from the system.

Identifying the sources of mercury that are more bioavailable and more readily methylated in EFPC is critical. If indeed sediment-bound mercury is the more important precursor for $\mathrm{MeHg}$ production and bioaccumulation, management actions that focus solely on decreasing aqueous inputs at the headwaters of EFPC may not be effective in reducing $\mathrm{MeHg}$ concentrations in fish. Consequently, this study examines the release of mercury from three different particulate sources in EFPC (floodplain soils, stream bank soils, and streambed sediments) into water over time under different conditions, as well as the bioavailability of the sediment-leached mercury to algae at the base of the aquatic food chain leading to fish. Whereas many studies focus on comparing dissolved mercury concentrations with those found in fish tissues, this study focuses on understanding the factors that control their build-up at the base of aquatic food webs. Researchers adopted this approach because the largest bioconcentration step of mercury from the aqueous phase into organisms occurs in microorganisms (algae, diatoms, fungi, and bacteria) that serve as the food web base. All other steps in the food chain preserve and slightly concentrate mercury concentrations in animals, but uptake at the base of the food chain largely controls mercury concentrations, and therefore toxicity, in a given system. 


\subsubsection{Approach}

All sediments were collected from upper EFPC (UEFPC), just downstream of the boundary with the Y-12 Complex ( EFK 23.0). Floodplain soils (behind the National Oceanic and Atmospheric Administration [NOAA] building), stream bed sediments (in the stream behind the NOAA building), and stream bank soils (in EFPC behind the guard shack on Bear Creek Road) were collected. Sediments were wet-sieved in situ to remove debris and coarse-grained particles $(>200 \mu \mathrm{m})$. Wet soils were stored frozen until use. Before the experiments took place, each sediment type was thawed and homogenized by spoon and by mortar and pestle, and a portion was dried in an oven $\left(100^{\circ} \mathrm{C}\right)$ for $>12 \mathrm{~h}$ to determine moisture content. Another portion was sent to CEBAM Analytical (Bothell, WA) for total mercury (HgT) and $\mathrm{MeHg}$ analysis (Table 10).

Table 10. Total (HgT) and methylmercury (MeHg) concentrations in different soil types collected from upper East Fork Poplar Creek (mg/kg dry sediment)

\begin{tabular}{lccc}
\hline \multicolumn{1}{c}{ Soil type } & \% dry & HgT $(\mathbf{m g} / \mathbf{k g})$ & MeHg $(\boldsymbol{\mu g} / \mathbf{k g})$ \\
\hline Streambed sediments & 64.49 & 40.60 & 13.65 \\
Floodplain soils & 58.95 & 24.59 & 14.78 \\
Stream bank soils & 67.80 & 909.90 & 21.51 \\
\hline
\end{tabular}

\section{Mercury Leaching Tests}

Mercury-contaminated sediment was incubated with "clean" filtered $(0.22 \mu \mathrm{m})$ water from upper First Creek (First Creek kilometer 0.9) at a mass ratio of 10:1 water:sediment, for a total mass of 2,000 g. Incubations were done at room temperature in the dark, in glass Erlenmeyer flasks $(4,000 \mathrm{~mL})$ covered with aluminum foil. All glassware was acid-soaked $(10 \% \mathrm{HCl})$ for 1 week and combusted in a muffle furnace before use. Flasks were fastened securely to an oscillating shaker-table and were agitated at 100 rotations per minute for approximately 3 weeks. Periodically, samples were taken for aqueous HgT, $\mathrm{MeHg}$, and dissolved organic carbon (DOC) content by pouring a slurry mixture into $50 \mathrm{~mL}$ centrifuge tubes and spinning at low speed (2,660 revolutions per minute) for $15 \mathrm{~min}$ at $20^{\circ} \mathrm{C}$ to remove suspended solids. Supernatant was measured for $\mathrm{pH}$, temperature, conductivity, and oxidation-reduction potential (ORP) before being syringe-filtered $(0.22 \mu \mathrm{m})$ into glass IChem vials for analysis (Table 11). Unfiltered supernatant also was collected to examine the $\mathrm{HgT}$ content in colloidal material. Samples for $\mathrm{HgT}$ were preserved with $\mathrm{BrCl}(200 \mu \mathrm{L}$ per $40 \mathrm{~mL}$ sample). Samples for DOC were preserved with $\mathrm{HCl}(20 \mu \mathrm{L}$ per $20 \mathrm{~mL}$ sample). Samples for $\mathrm{MeHg}$ were frozen until analysis. A second set of experiments was conducted with floodplain soils incubated as described above with water from First Creek and Clinch River to examine the effect of different water chemistries on mercury release. Clinch River water was collected from the flow augmentation station and was filtered through a $0.22 \mu \mathrm{m}$ filter before experiments. The sediment:water mass ratio in these experiments was 9 parts water: 1 part sediment, and these sediments were incubated for 2 weeks. 
Table 11. Methylmercury (MeHg) and dissolved organic carbon (DOC) in sediment leaching tests

\begin{tabular}{lcccc}
\hline \multirow{2}{*}{ Sample type } & \multicolumn{2}{c}{ DOC $(\mathbf{m g} / \mathbf{L})$} & \multicolumn{2}{c}{ MeHg $(\mathbf{n g} / \mathbf{L})$} \\
\cline { 2 - 5 } & Begin & End & Begin & End \\
\hline First Creek water & 1.28 & ND & $<0.02$ & ND \\
Clinch River water & 1.77 & ND & $<0.02$ & ND \\
& First & Creek water incubated with the following: & \\
Streambed sediments & 6.52 & 18.69 & 0.47 & 0.68 \\
Stream bank soils & 4.14 & 10.21 & 2.25 & 2.28 \\
Floodplain soils & 9.41 & 11.38 & 0.43 & 0.02 \\
\hline
\end{tabular}

Note: $\mathrm{ND}=$ not detected.

\section{Algae Uptake Experiments}

Water from leaching experiments was separated from sediments by centrifugation and then sterile filtration $(0.22 \mu \mathrm{m})$ into autoclaved $50 \mathrm{~mL}$ glass test tubes with loosely affixed Teflon screw caps. Water was amended with WCL-1 media nutrients for algal culture (Guillard 1975), except without trace metals and ethylenedinitrilotetraacetic acid. Two sets of tubes were prepared: treatments and controls. The control tubes received the same treatment (mercury-contaminated water + WCL-1 nutrients, but no cells). The control media was used to measure mercury sorption onto filters over time. To calculate the mercury accumulated in cells, mercury sorbed onto filters was subtracted from the total (cells + filters) concentrations. In treatment tubes, the green algae Chlamydomonas reinhardtii was inoculated into tubes at an initial cell density of 20,000 cells $/ \mathrm{ml}$. Cell growth was monitored by chlorophyll a fluorescence using a Turner fluorometer, as well as with a hemocytometer. Total mercury was monitored in cells after $4 \mathrm{~d}$, and concentrations were normalized to a per cell basis. Cells were separated from media by filtration on a Nuclepore filter $(0.22 \mu \mathrm{m})$, which was incubated for $5 \mathrm{~d}$ in $5 \% \mathrm{BrCl}$ solution at $50^{\circ} \mathrm{C}$ before mercury analysis by cold vapor atomic absorption spectrometry.

\subsubsection{Results of Laboratory Studies}

Total and methylmercury concentrations in the different soil types used in this study are shown in Table 10. The stream bank soils had the highest mercury concentrations by far, with dry weight HgT concentrations over an order of magnitude greater than the other two soil types. Methylmercury concentrations were also higher in stream bank soil than in the other two soil types, but the difference in $\mathrm{MeHg}$ concentrations was not as marked as that of the HgT concentrations.

Streambed sediments had twice the HgT content of floodplain soils, but $\mathrm{MeHg}$ concentrations were similar between the two soil types. These concentrations are consistent with previous findings, which have identified the stream banks in UEFPC as having the highest concentrations of $\mathrm{HgT}$ of all particulate sources studied (Southworth et al. 2013; Southworth et al. 2010).

The differences in mercury content in sediment resulted in differences in HgT leaching into First Creek water (Fig. 29). Streambed sediments, which had approximately twice the HgT content of floodplain soils, released about twice the $\mathrm{HgT}$ content into the dissolved phase after the first few hours of incubation.

Stream bank sediments, which had approximately 20-40 times higher HgT content than the other two soil types, released over 100 times more $\mathrm{HgT}$ into the dissolved phase within a few hours of incubation. Over time, the HgT released by floodplain and stream bank soils increased, both in the aqueous phase and in the colloidal phase, whereas it appears that the $\mathrm{HgT}$ released by streambed sediment reached equilibrium rapidly and did not change over time either in the aqueous or colloidal phase. 

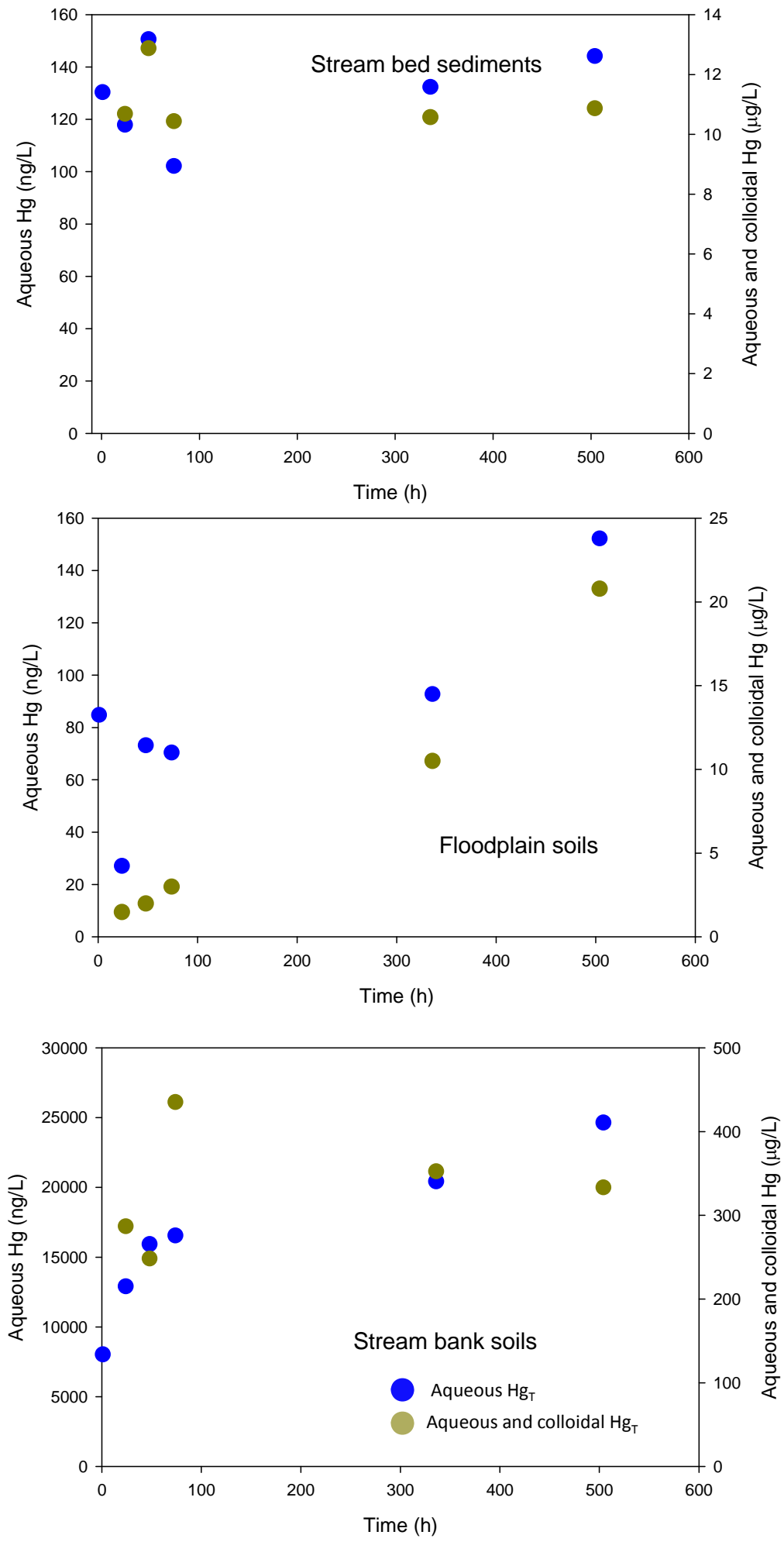

Fig. 29. Total aqueous and aqueous + colloidal HgT in water incubated with water from upper First Creek and streambed sediments, floodplain soils, and stream bank soils collected from upper East Fork Poplar Creek at a water:soil ratio of 10:1. 
The differences in the patterns of mercury release from the different particulate types suggest differences in speciation and/or complexation with the surface of the particles. It appears that the desorption of mercury occurred rapidly to equilibrate mercury concentrations between particulate and dissolved phases once in contact with clean water from First Creek. There was no longer-term, slow release of mercury from these particles, possibly because the streambed sediments were constantly in contact with flowing water before collection and already had released any loosely bound mercury associated with these particles. The other two particulate types used in this study only come into contact sporadically during wet weather and storm events, and, perhaps as a result, the longer-term contact with water in these incubations was able to release more mercury from these particles over time.

Floodplain soils, which had half the HgT content of streambed sediments, released as much mercury into the aqueous phase and twice as much mercury into the colloidal phase as the streambed sediments by the end of the 3-week incubation period. One explanation for this could be that the chemistry of the water exposed to floodplain soils was changing over time. The $\mathrm{pH}$ of the floodplain incubations decreased slowly over time (Table 12), whereas the ORP increased over time. Visually, it was clear that there was increasing colloidal material in the floodplain incubations over time. The supernatant of centrifuged samples went from being fairly clear to being orange and rust-colored as the experiment went on. Floodplain soils from this region of EFPC have much higher iron content than the other two soil types used in this study. The colloidal material was most likely iron oxide precipitates because the iron was being oxidized with the incubation with water over time. The decrease in $\mathrm{pH}$ would favor such precipitation and also would favor mercury desorption.

Table 12. Oxidation-reduction potential (ORP), $\mathrm{pH}$, and conductivity over time in incubations with different particle types

\begin{tabular}{lccccc}
\hline & \multicolumn{5}{c}{ Incubation time (hours) } \\
\cline { 2 - 6 } & $\mathbf{0}$ & $\mathbf{2 4}$ & $\mathbf{7 6}$ & $\mathbf{3 3 6}$ & $\mathbf{5 0 4}$ \\
\hline $\mathrm{pH}$ & 7.48 & Streambed & & & \\
ORP & 6.90 & 7.76 & 7.52 & 7.62 \\
Conductivity & 271.00 & 288.00 & 237 & 252 & 255 \\
& 317.40 & 353.60 & 291.5 & 322.3 & 313.3 \\
pH & \multicolumn{5}{c}{ Stream bank soils } \\
ORP & 7.86 & 7.75 & 7.67 & 7.54 & 7.42 \\
Conductivity & 366.00 & 242.00 & 258 & 264 & 272 \\
& 243.80 & 235.90 & 235.6 & 222.4 & 217 \\
pH & 7.52 & Floodplain & & & \\
ORP & 7.68 & 7.35 & 7.02 & 6.88 \\
Conductivity & 243.00 & 237.00 & 260 & 280.2 & 284 \\
& 302.80 & 292.80 & 255.8 & 238.4 & 207.8 \\
\hline
\end{tabular}

Similar to floodplain soils, stream bank soils continued to release mercury into the aqueous phase over time, although it appears that release was biphasic, with a more rapid release in the first few days of incubation and a slower (but still significant) release for the last 2 weeks of the experiment. Mercury in the colloidal phase did not appear to change over time with stream bank incubations. Similar to the floodplain soils, the $\mathrm{pH}$ of the supernatant in the stream bank incubations decreased slowly but steadily over time, which would favor desorption of mercury from particulate matter. However, the ORP of the supernatant in the stream bank incubation decreased over time, suggesting that the supernatant tended toward a reductive environment. 
Previous work has shown that DOC can enhance the leaching and/or solubilization of mercury from EFPC sediments (Mathews et al. 2011). Not surprisingly, DOC concentrations in all three soil incubations were higher than concentrations in First Creek water alone and increased slightly over the 3-week incubation period (Table 12). DOC concentrations increased most in the streambed incubations and least in the floodplain soil incubations.

To examine the effect of different water chemistries on mercury desorption, floodplain soils were incubated with water collected from First Creek and from the Clinch River (Fig. 30). Mercury was released more readily from soil particles into water from First Creek than into Clinch River water, with aqueous $\mathrm{HgT}$ concentrations approximately threefold higher in incubations with First Creek water at the end of the experiment. The research team initially hypothesized that this could be because of differences in DOC concentration between the two water types; however, this turned out not to be the case because concentrations were very similar in First Creek and Clinch River water (Table 12). This difference in mercury leaching between the two water types is interesting and also is relevant to the EFPC situation. Water from the Clinch River has been routed to upper EFPC for flow augmentation to decrease the mercury flux out of the Y-12 Complex through dilution. Currently, there are tentative plans to either remove this flow augmentation (unlikely) or relocate the site of the flow augmentation input (more likely). Clearly, the different water types have different abilities to leach mercury from particulate matter, but it is not immediately apparent why this should be the case. Dissolved organic carbon concentrations, $\mathrm{pH}$, ORP, and conductivity were similar in the two water types (Tables 11 and 13). Future work should characterize the DOC in the two water types, in addition to measuring absolute concentrations.

Note that the absolute concentrations shown in the top panel of Fig. 30, for leaching of floodplain soils into First Creek water, are higher than the absolute concentrations shown in the middle of Fig. 29. This is because the ratio of water:sediment was different between the two experiments (10:1 for the experiment shown in Fig. 29, and 9:1 for the experiment shown in Fig. 30). However, the patterns of leaching are similar between the two experiments - slow release in the first $2 \mathrm{~d}$ of the experiment, followed by a much more rapid release. This is likely due to redox conditions, which are changing in the incubations with this sediment over time, as explained above.

Methylmercury concentrations in all three sediment incubations did not increase over time during the incubation period (Table 11). Methylmercury concentrations appeared to stay the same in the streambed and stream bank incubations but actually decreased in the floodplain incubation. Interestingly, the patterns of mercury bioaccumulation in C. reinhardtii over a $4 \mathrm{~d}$ period follow the $\mathrm{MeHg}$ concentrations in the culture media, rather than follow the total mercury concentrations. Figure 31 shows the mercury concentrations on a per gram basis to account for differences in cell growth due to the different nutrient concentrations in the treatments. The cells in the floodplain incubations showed no appreciable mercury uptake over the $4 \mathrm{~d}$ period, whereas cells in the streambed incubations increased from 1 to $10 \mathrm{mg} / \mathrm{g}$, and cells in the stream bank incubations increased from 202 to $442 \mu \mathrm{g} / \mathrm{g}$. Despite the nearly identical initial $\mathrm{HgT}$ concentrations between the streambed and floodplain algal media, algae in the floodplain exposures did not accumulate measurable $\mathrm{HgT}$ concentrations. Researchers hypothesize that the accumulation of $\mathrm{HgT}$ in algae is related to the speciation of mercury in the media. The higher MeHg concentrations in the streambed and stream bank media suggest that $\mathrm{MeHg}$ is accumulated much more readily into algal cells than inorganic mercury is accumulated and controls mercury uptake much more so than inorganic mercury concentrations. This is an important finding and may explain, at least in part, why fish tissue concentrations in EFPC have not decreased over time despite drastic decreases in HgT concentrations throughout the creek (Southworth et al. 2011). It also is possible that some $\mathrm{HgT}$ in the stream bank incubations was speciated as elemental mercury $(\mathrm{Hg}[0])$; researchers believe, based on $\mathrm{HgT}$ concentrations, that these soils come from the HRD in EFPC. Future work will investigate the presence of $\mathrm{Hg}(0)$ through headspace analysis of incubations and also will examine the relative accumulation of $\mathrm{HgT}$ vs. $\mathrm{MeHg}$ in algae and other biota using radioisotopes. 

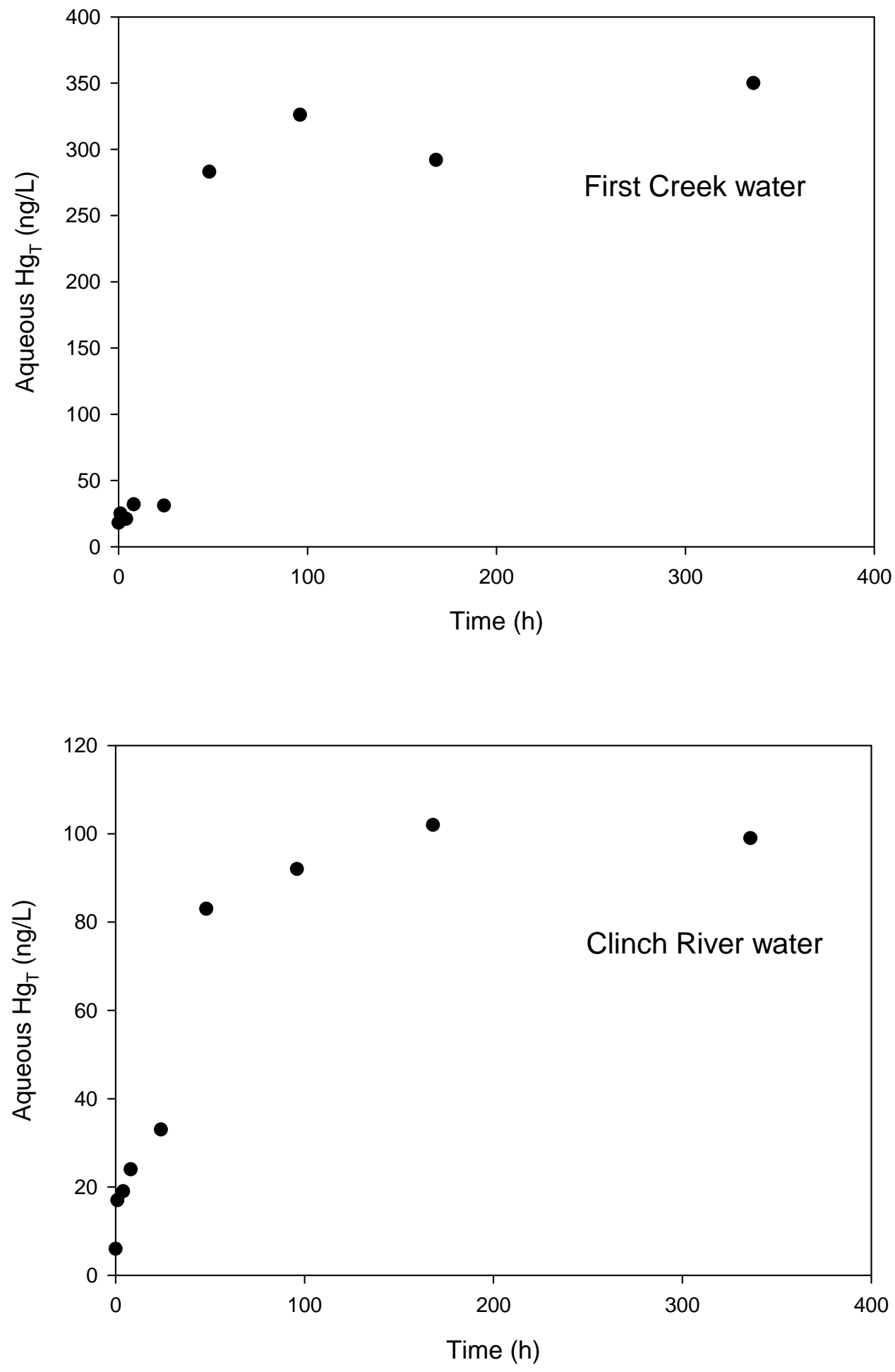

Fig. 30. Total aqueous mercury (HgT) in water incubated with water from upper First Creek and from the Clinch River with floodplain soils from upper East Fork Poplar Creek at a water:soil mass ratio of 9:1. 
Table 13. Characteristics of filtered $(0.22 \mu \mathrm{m})$ water collected from the Clinch River and First Creek.

\begin{tabular}{lcc}
\hline \multicolumn{1}{c}{ Characteristic } & Clinch River water & First Creek water \\
\hline $\mathrm{pH}$ & 8.29 & 8.4 \\
Oxidation-reduction potential $^{1}$ & 236 & 226 \\
${ }^{\text {Conductivity }}$ & 314 & 235.9 \\
${ }^{1} \mathrm{mV}$ & & \\
${ }^{2}$ microSiemens & &
\end{tabular}

\subsubsection{Discussion of laboratory studies}

Several activities were undertaken to understand the role of different particulate sources in contributing to overall aqueous $\mathrm{Hg}$ and $\mathrm{MeHg}$ concentrations in EFPC, as well as the contribution of these particulate sources to the bioavailable fraction of $\mathrm{Hg}$ and $\mathrm{MeHg}$ throughout the creek. The results from this preliminary study confirmed earlier results (Southworth et al. 2011) that indicated the presence of the HRD in EFPC and prompted an in-depth investigation to characterize the extent of this high-mercury layer of soil throughout the EFPC floodplain (Peterson et al. 2015). The results from these studies also quantified the relative importance of floodplain, streambank, and streambed sediments in contributing to aqueous $\mathrm{Hg}$ and $\mathrm{MeHg}$ in the creek, highlighting that streambank erosion plays a major role in contributing to $\mathrm{Hg}$ and $\mathrm{MeHg}$ fluxes in LEFPC. The leaching experiments with different water types (First Creek vs. Clinch River water) indicate that water chemistry may play a role in how mercury partitions between aqueous and particulate phases. Particulate mercury was released more readily into First Creek water than into Clinch River water (which was used for flow augmentation), suggesting that changes in water chemistry due to the shut off of flow augmentation may affect dissolved mercury concentrations, especially in UEFPC. These findings also gave rise to more in-depth studies to characterize the role of water chemistry in controlling mercury dynamics throughout the creek (Peterson et al. 2015). Finally, the algal uptake experiments highlight that mercury released from particulate sources is bioavailable and can be taken up by biota at the base of the aquatic food chain. Because uptake at the base of the food chain is the most important bioconcentration step in the food chain, understanding the bioavailability of mercury release from different sources is relevant to explaining the patterns of bioaccumulation seen in fish in EFPC. 


\section{Mercury sorption onto C. reinhardtii cells}

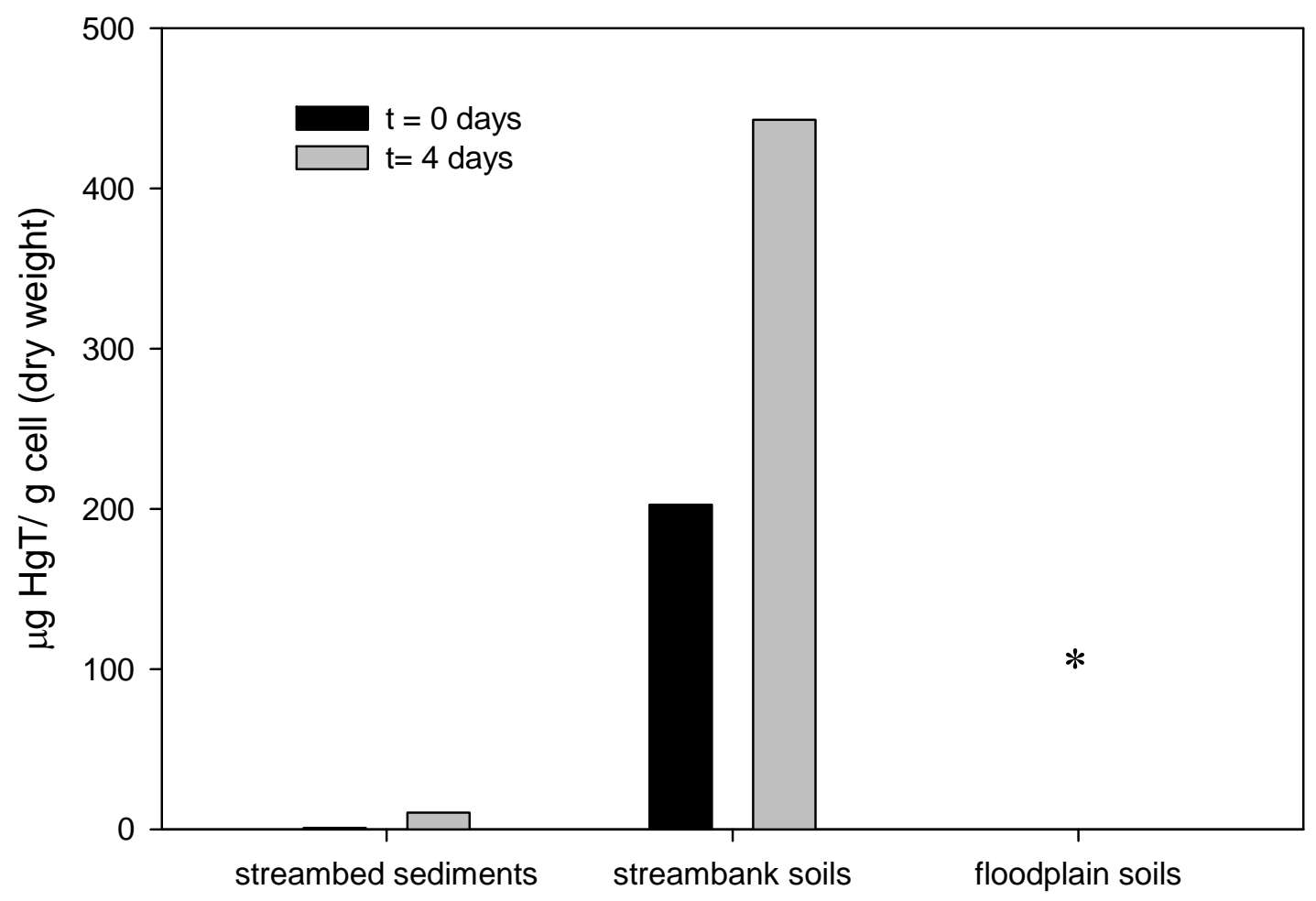

Fig. 31. Total mercury (HgT) accumulation onto Chlamydomonas reinhardtii cells after incubation with water exposed to different soil types. Black bars show concentrations after $<10 \mathrm{~min}$ of exposure, whereas gray bars show concentrations after $4 \mathbf{d}$ of exposure. *Mercury concentrations in algae exposed to floodplain-leached water were not higher than control filters. 


\subsection{MODEL INPUT PARAMETERS AND ASSUMPTIONS}

\subsubsection{Overall Model Framework}

Specific data inputs, equations, and assumptions used in the modeling effort are described in this section. For the purposes of the model, EFPC has been divided into five different reaches (Fig. 6), with estimates of average flux and concentration made on a monthly time increment at the downstream end of each reach (Fig. 7). The framework for how mercury fluxes and processes are incorporated into the watershed model is shown in Fig. 32.

The downstream boundary of the first upstream modeling reach is coincident with Station 17, which has considerable historical data on flows, mercury concentrations, and fluxes. The downstream boundary of the last downstream reach is coincident with the US Geological Survey (USGS) gauging station at EFK 5.4, which also has associated historical information as well as recent investigations conducted as part of the Mercury Science Focus Area (SFA) project (Riscassi, Miller, and Brooks 2015). The historical data from Station 17 was used to calculate the upstream monthly average flow and mercury inputs coming from Y-12 (UEFPC) to LEFPC; similarly, calculations for EFK 5.4 were made to estimate the monthly average flow and mercury fluxes leaving the model domain. The model is set up to represent typical average monthly flow conditions with flow augmentation in UEFPC turned off because that is the current and likely future condition.

Flow inputs to each of the modeled stream reaches were added incrementally to the Station 17 flow inputs to make the flows add up to the estimated average monthly flows at EFK 5.4. Calculated average monthly flows from the Oak Ridge Wastewater Treatment Facility (ORWTF) were obtained from the City of Oak Ridge and were added to the EFK 16-12 reach (Figs. 6 and 32). The remainder of the flow difference between EFK 5.4 and Station 17 was divided and used as input to each of the reaches based on the proportion of the LEFPC watershed drainage area associated with each reach. LEFPC is flashy, with the magnitude of stream flow increasing considerably during large precipitation events. Some of the mercury processes (e.g., bank erosion) are dependent on these flow conditions, so it was important to estimate the proportion of the monthly average flow that is stormflow versus base flow conditions from the stream hydrographs.

As shown in Fig. 32, the model includes estimates of fluxes of IHg and MeHg coming into each of the reaches and the impacts of instream processes occurring in each of the reaches. The influx to each stream reach includes estimates of what is flowing into the reach from the upstream reach, additional inputs from bank erosion, and overland flow and infiltration from the floodplain. Estimates of the inflow of clean water and clean TSS that enter the system within each of the reaches and its impact on $\mathrm{IHg}$ and $\mathrm{MeHg}$ concentrations also are included in the model. Instream processes considered include $\mathrm{MeHg}$ production (e.g., from periphyton), and select sediment deposition and mobilization ( $\mathrm{IHg}$ and $\mathrm{MeHg}$ ), and partitioning processes.

With this modeling framework defined, site-specific data from the EFPC watershed was used to help parameterize the mercury processes, transformations, and connections linking various model compartments and defining within-compartment interactions. The model incorporates newly collected field and laboratory data for this study with past and more recent findings from multiple US Department of Energy (DOE) programs including Environmental Management (EM; e.g., BMAP, Mercury Remediation Technology Development [TD], and Applied Field Research Initiative), Office of Science (Mercury SFA project), and the Y-12 Compliance Department. 




Fig. 32. Model framework showing stream reaches, inorganic mercury (IHg) and methylmercury (MeHg) inflow and outflow, and instream processes considered in the model. (Notes: EFK = East Fork Poplar Creek kilometer; TSS $=$ total suspended solids.)

\subsubsection{Geospatial Data Compilation}

A geospatial database for the EFPC watershed was developed from national, state, and local information sources to allow for mapping and analysis of the physical characteristics of the watershed and to facilitate understanding and conceptualization of the LEFPC watershed. Numerous geospatial visualizations and analyses (Table 14) were incorporated into the mercury flux and concentration estimations described in subsequent sections. 
Table 14. Geospatial data sources

\begin{tabular}{|c|c|c|c|c|}
\hline Dataset name & Source agency & Online linkage & $\begin{array}{l}\text { Geographic } \\
\text { resolution }\end{array}$ & Description \\
\hline $\begin{array}{l}\text { County and } \\
\text { watershed } \\
\text { boundaries, soils, } \\
\text { geology, wetlands }\end{array}$ & $\begin{array}{c}\text { Tennessee } \\
\text { federal GIS data } \\
\text { server }\end{array}$ & http://www.tngis.org/ & County & $\begin{array}{l}\text { Polygon and line datasets } \\
\text { representing physical } \\
\text { features in Tennessee }\end{array}$ \\
\hline $\begin{array}{l}\text { Aerial imagery } \\
\text { and } \\
\text { elevation (DEM) } \\
\text { data }\end{array}$ & $\begin{array}{c}\text { Oak Ridge } \\
\text { Environmental } \\
\text { Information } \\
\text { Systems } \\
\text { (OREIS) } \\
\end{array}$ & $\begin{array}{c}\text { http://www- } \\
\text { oreis.ettp.energy.gov/ore } \\
\text { is/help/ oreishome.html\# }\end{array}$ & $\begin{array}{l}\text { Local } \\
(1 \mathrm{~m} \\
\text { resolution })\end{array}$ & $\begin{array}{c}\text { Aerial imagery was } \\
\text { obtained during the periods } \\
\text { of 1993, 1998, and 2006, } \\
\text { whereas the DEM was } \\
\text { from } 1993\end{array}$ \\
\hline $\begin{array}{l}\text { Hydrology } \\
\text { (watershed } \\
\text { boundaries, } \\
\text { streams, and } \\
\text { rivers) } \\
\end{array}$ & $\begin{array}{c}\text { National } \\
\text { Hydrology Data } \\
\text { Sets (NHDS) }\end{array}$ & $\frac{\text { http://nhd.usgs.gov/data. }}{\underline{\mathrm{html} /}}$ & Variable & Polygon and line datasets \\
\hline $\begin{array}{l}\text { Elevation, land } \\
\text { cover, geology }\end{array}$ & $\begin{array}{c}\text { USGS National } \\
\text { Map Viewer }\end{array}$ & $\frac{\text { http://viewer.nationalma }}{\text { p.gov/viewer/ }}$ & Variable & Polygon and line datasets \\
\hline $\begin{array}{l}\text { Soils data } \\
\text { (SSURGO) }\end{array}$ & NRCS USDA & $\frac{\text { http://gis.apfo.usda.gov/ }}{\text { gisviewer/ }}$ & County & Polygon datasets \\
\hline Flood hazard data & FEMA & http://msc.fema.gov & County & Polygon and line datasets \\
\hline Geology & USGS & $\begin{array}{r}\frac{\text { http://mrdata.usgs.gov/ge }}{\text { ology/state/state.php?stat }} \\
\mathrm{e}=\mathrm{TN}\end{array}$ & State & Polygon and line datasets \\
\hline $\begin{array}{l}\text { ORR and ORNL } \\
\text { specific data }\end{array}$ & $\begin{array}{l}\text { ORNL Shared } \\
\text { Data Initiative }\end{array}$ & NA & Local & $\begin{array}{c}\text { Map info data files } \\
\text { developed over a period of } \\
10 \text { years } \\
\end{array}$ \\
\hline Kayak data & $\begin{array}{l}\text { Paul Ayers, } \\
\text { University of } \\
\text { Tennessee }\end{array}$ & NA & EFPC specific & $\begin{array}{c}\text { Point data from EFPC } \\
\text { stream }\end{array}$ \\
\hline EFPC data layers & $\begin{array}{l}\text { Kocman and } \\
\text { Scott Brooks }\end{array}$ & NA & $\begin{array}{c}\text { EFPC } \\
\text { watershed } \\
\end{array}$ & Polygon and line datasets \\
\hline $\begin{array}{l}\text { Analytical } \\
\text { data (biota, lab, } \\
\text { and field) }\end{array}$ & (OREIS) & $\begin{array}{l}\text { http://www- } \\
\text { oreis.ettp.energy.gov/ore } \\
\text { is/help/ oreishome.html\# }\end{array}$ & Point locations & $\begin{array}{l}\text { Biota, soil, and surface } \\
\text { water sampling data } \\
\text { collected at point locations } \\
\text { from } 1985 \text { to } 2012 \\
\end{array}$ \\
\hline
\end{tabular}

\subsubsection{Flow Estimates}

Average monthly flows (with flow augmentation subtracted) for Station 17 (1992-2013 data) and EFK 5.4 (1960-1987 data) were calculated from flow data available from the Oak Ridge Environmental Information System (OREIS; Fig. 33). Flow augmentation ( $\sim 0.2$ cubic meters/second [cms]) was subtracted from the reported flow when it was determined to be active for the calculation of these averages. As shown in Fig. 33, average monthly flows at EFK 5.4 are much lower in the summer and fall than they are in the spring and winter, with a maximum monthly average of $2.27 \mathrm{cms}$ in March and a minimum of $0.81 \mathrm{cms}$ in September. On a yearly basis, approximately $50 \%$ of the flow at EFK 5.4 was estimated to be stormflow, and the remaining $50 \%$ was base flow.

However, base flow comprises a greater percentage of the flow in the drier summer and fall months, whereas the percent stormflow is higher than base flow in the wetter winter and spring months. Station 17 has a similar, although much less pronounced, seasonal trend, with a maximum monthly average of 
$0.24 \mathrm{cms}$ in January and February and a minimum of $0.17 \mathrm{cms}$ in August and October. Monthly average flows estimated for ORWTF were similar in magnitude to Station 17 flows, averaging $0.18 \mathrm{cms}$ compared with $0.195 \mathrm{cms}$ at Station 17. The stormflow volumes for ORWTF and Station 17 were estimated to be 22 and $25 \%$ of the total flow, respectively.

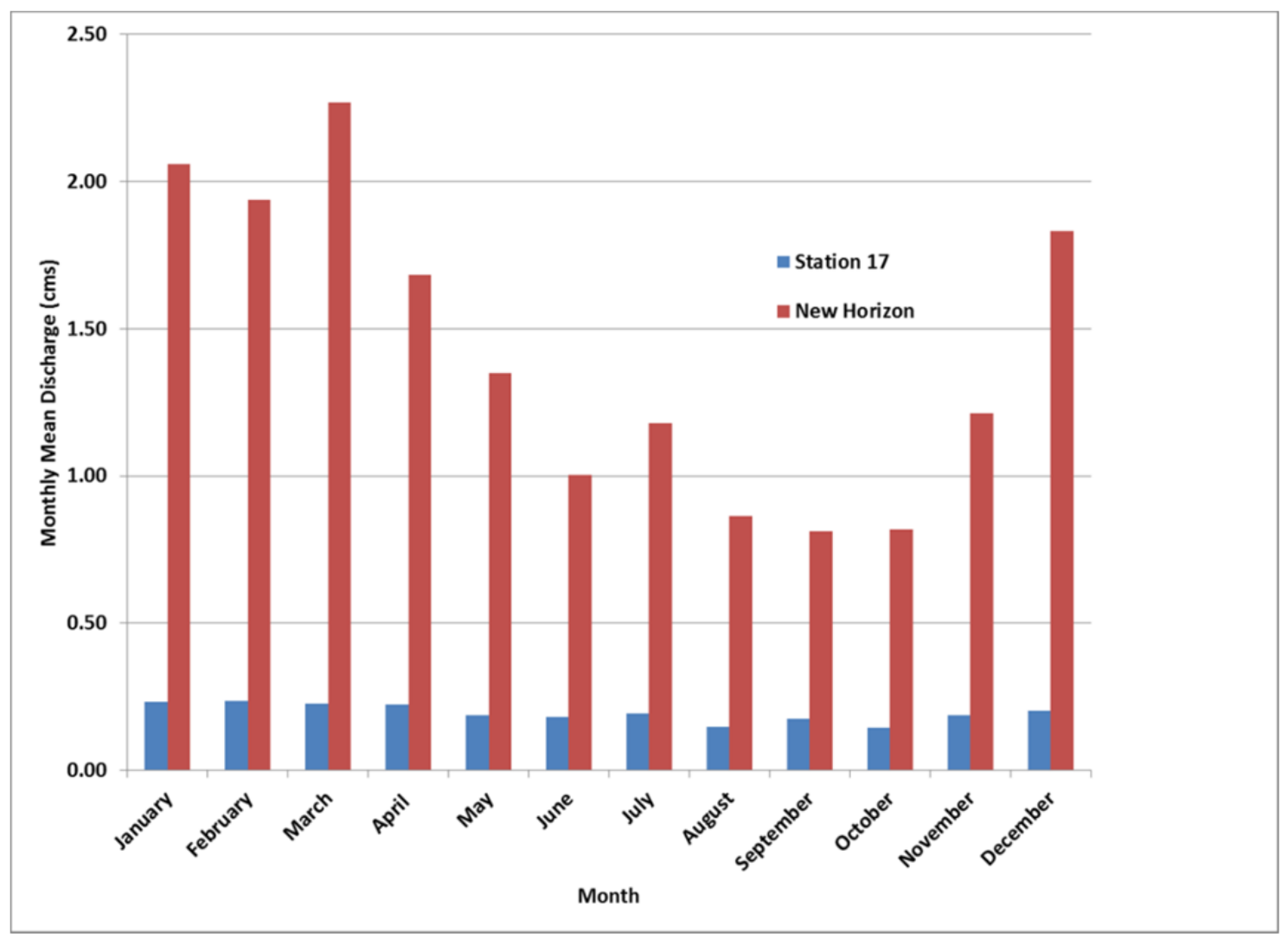

Fig. 33. Average monthly flows (cubic meters/second [cms]) for Station 17 (1992-2013) and East Fork Poplar Creek kilometer (EFK) 5.4 (1960-1987) without flow augmentation.

For the purposes of estimating and comparing the differences between the Station 17 inflow flux and the EFK 5.4 outflow flux, more discretized flow measurements were required to better capture the LEFPC flow dynamics. For Station 17, 5 min increment flow data were obtained from Y-12 compliance for the period of January 1, 2006, through April 6, 2015. For EFK 5.4, 15 min increment flow data collected by ORNL for the period of February 13, 2012, to April 30, 2015, was used (see Fig. 34 ). The maximum flows measured during these periods were $17.6 \mathrm{cms}$ at Station 17 and $111 \mathrm{cms}$ at EFK 5.4. 


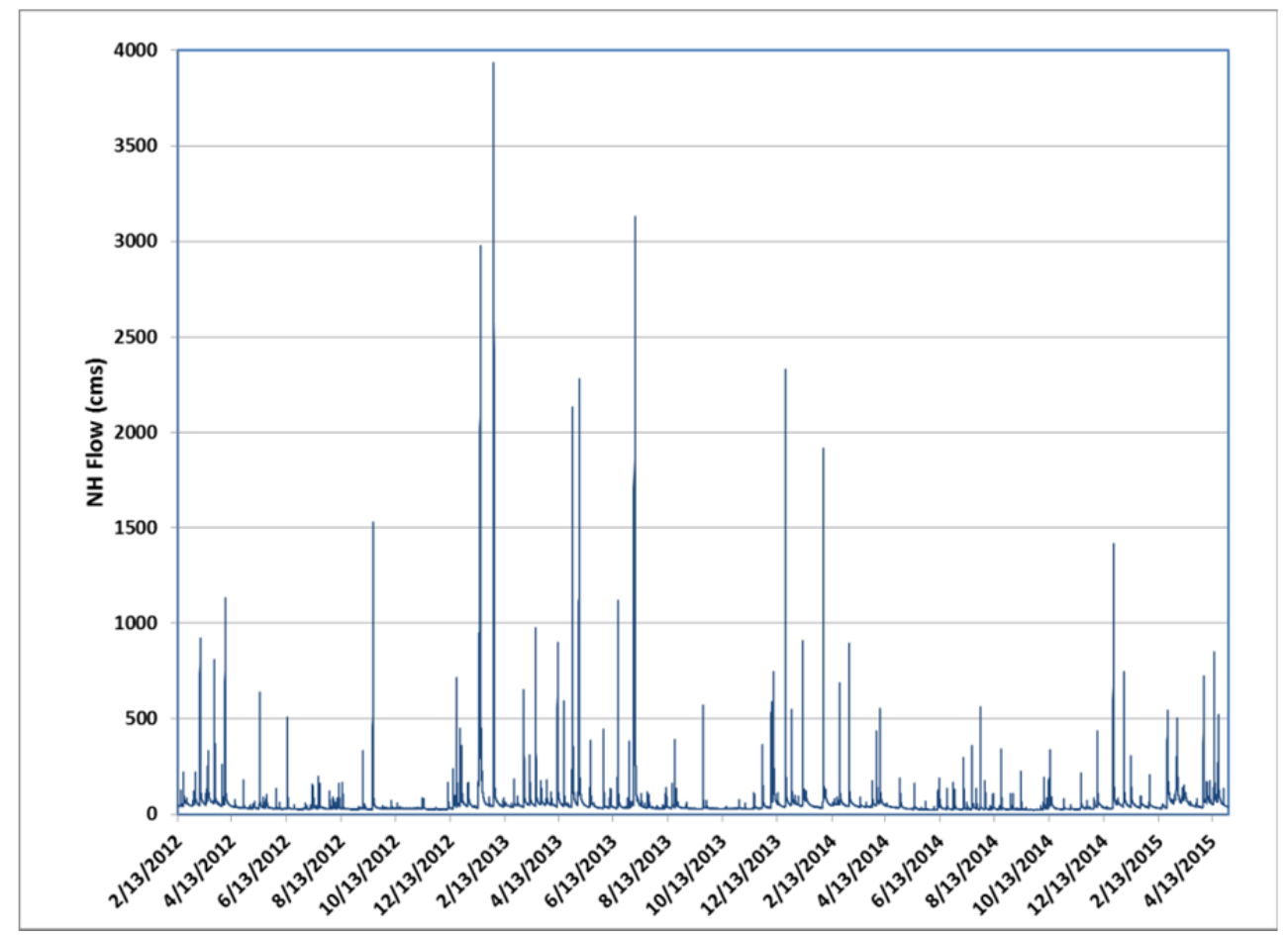

Fig. 34. Horizon Center (NH; East Fork Poplar Creek kilometer 5.4) 15 min increment flow data from February 13, 2012, to April 30, 2015 (cubic meters/second [cms]).

\subsubsection{Estimates of Mercury Fluxes at Station 17 (Inflow) and Horizon Center (Outflow)}

Weekly flow-weighted HgT (unfiltered) sample data for Station 17 (Fig. 35) were obtained from OREIS and combined with Station 17 flow data to calculate weekly HgT fluxes. Although there is some baseline sampling data for $\mathrm{MeHg}$ at Station 17, there is very little time series data that could be used to determine a MeHg/flow relationship. TDEC (Shiao and Peryam Undated, 2009) has conducted some storm sampling along LEFPC that indicates the total flux of $\mathrm{MeHg}$ at Station 17 during storm events may be on the order of $10 \%$ of the flux at EFK 5.4 .

By conducting stormflow sampling at EFK 5.4 under variable flow conditions, the mercury SFA project (Riscassi, Miller, and Brooks 2015) has been able to develop concentration vs. flow relationships for particulate mercury ( $\mathrm{HgP}), \mathrm{HgD}, \mathrm{HgT}$, particulate $\mathrm{MeHg}(\mathrm{MeHgP}), \mathrm{MeHgD}$, total $\mathrm{MeHg}(\mathrm{MeHgT})$, and TSS at EFK 5.4. The equations and type curves developed for these concentrations vs. flow relationships for EFK 5.4 are shown in Fig. 36. The flow/concentration equations and $15 \mathrm{~min}$ increment data were used to estimate fluxes at EFK 5.4. The HgT fluxes were converted to weekly fluxes for comparison with the Station 17 weekly fluxes. Figure 37 shows the relationship between the average weekly flow at EFK 5.4 and the weekly difference in HgT flux between EFK 5.4 and Station 17. Figure 37 also shows that during low flow conditions (base flow), the HgT fluxes at Station 17 and EFK 5.4 are similar, and net HgT flux into LEFPC is nearly equal to what leaves at EFK 5.4. However, under stormflow conditions, the flux of HgT leaving at EFK 5.4 can be substantially greater than what enters at Station 17.

From this assessment, the flux of $\mathrm{HgT}$ at Station 17 was determined to average $\sim 11.4 \mathrm{~kg} / \mathrm{year}$ (with flow augmentation on). The flux of $\mathrm{HgT}$ at EFK 5.4 was estimated to average $\sim 38 \mathrm{~kg} /$ year. However, it should be noted that the estimates for EFK 5.4 were not measured fluxes; they were estimated by plugging the February 13, 2012, to April 30, 2015, 5 min increment flow measurements into the flow-concentration equations shown in Fig. 36. The estimated net increase in HgT flux between Station 17 and EFK 5.4 averaged $\sim 27 \mathrm{~kg} /$ year, mostly as $\mathrm{HgP}$. This suggests that there is a substantial source of $\mathrm{HgT}$ entering 
LEFPC downstream of Station 17. The source of HgT that comes from LEFPC is estimated to be more than two times greater than the flux of mercury originating upstream of Station 17 in UEFPC and is related primarily to fluxes that occur during stormflow conditions.

The estimate of MeHgT flux averages $\sim 38 \mathrm{~g}$ /year at EFK 5.4, but the MeHgT flux at Station 17 is estimated to be only $\sim 10 \%$ of the EFK 5.4 flux (i.e., $\sim 3.8 \mathrm{~g} / \mathrm{year}$ ). The base flow flux of MeHgT at Station 17 is estimated to be $\sim 1.1 \mathrm{~g} /$ year, and at EFK 5.4, it is estimated to be $\sim 13 \mathrm{~g} /$ year. In general, a much higher percent of $\mathrm{MeHg}$ is in the dissolved form (50\% or greater) compared with the $\mathrm{IHg}$ form (less than 20\%). These estimates indicate that the great majority of $\mathrm{MeHg}$ is generated downstream of Station 17.

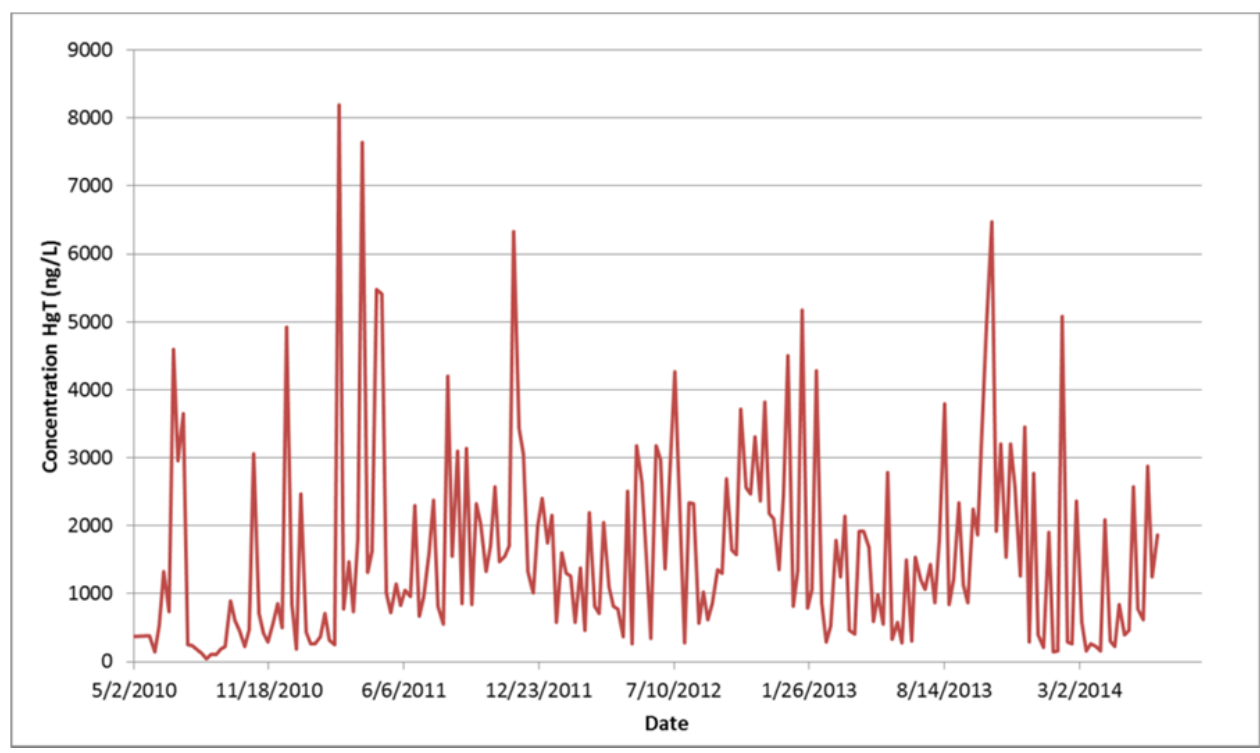

Fig. 35. Weekly flow weighted total mercury (HgT; unfiltered) sample data for Station 17 obtained from the Oak Ridge Environmental Information System was used to calculate weekly HgT fluxes. 

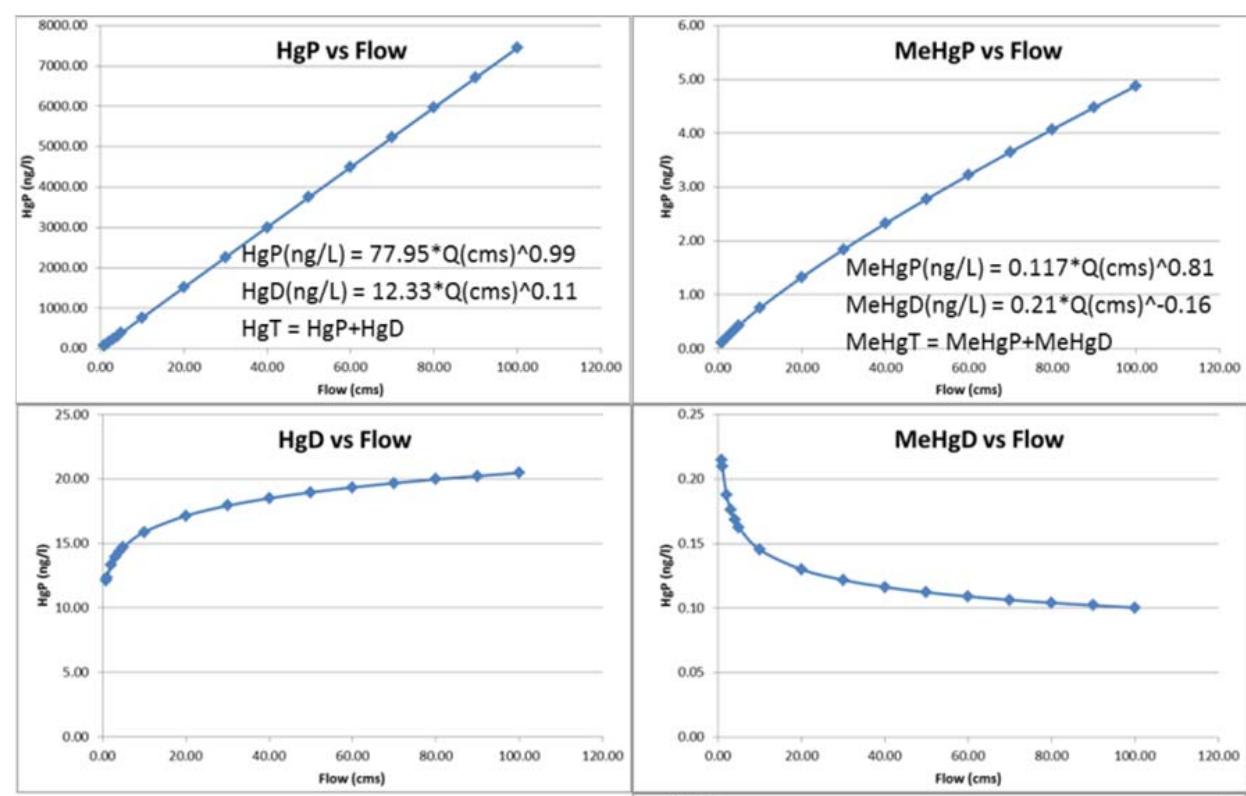

$\mathrm{HgP}=$ particulate $\mathrm{Hg}$

$\mathrm{HgD}=$ dissolved $\mathrm{Hg}$

$\mathrm{MeHgP}=$ particulate $\mathrm{MeHg}$

$\mathrm{MeHgD}=$ dissolved $\mathrm{MeHg}$

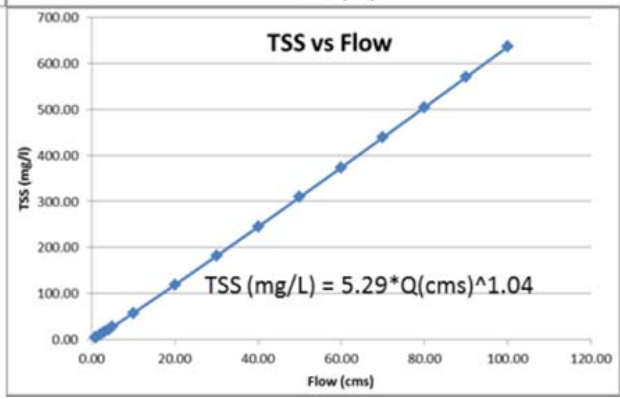

Fig. 36. Concentration vs. flow relationships for New Horizon (East Fork Poplar Creek kilometer [EFK] 5.4) developed from stormflow sampling can be used to estimate HgP, HgD, total mercury (HgT), MeHgP, MeHgD, total MeHg (MeHgT), and total suspended solids (TSS) concentration and fluxes at EFK 5.4 under various flow conditions. (Source: Riscassi, A. L., C. Miller, and S. Brooks. 2015. "Seasonal and Flow-Driven Dynamics of Particulate and Dissolved Mercury and Methylmercury in a Stream Impacted by an Industrial Mercury Source.” Environmental Toxicology and Chemistry. doi: 10.1002/etc.3310. Published online Nov. 17, 2015.) 


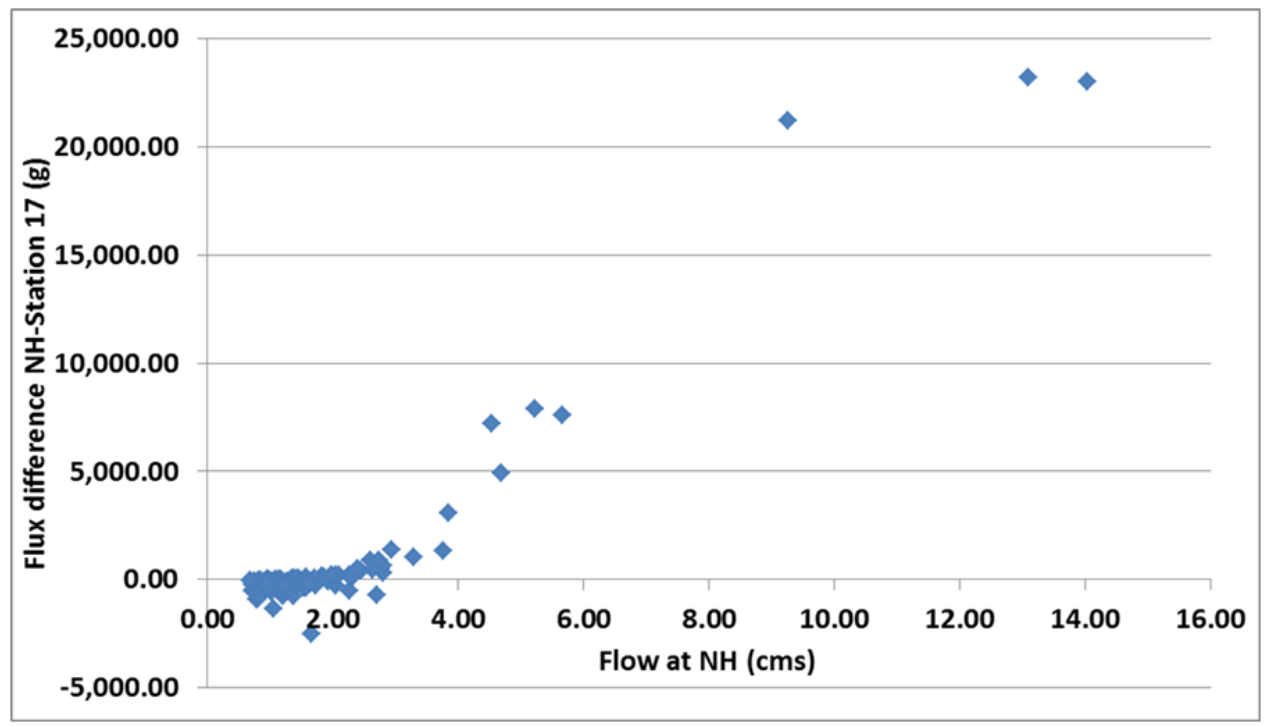

Fig. 37. Relationship of average weekly flow (cubic meters/second [cms]) at Horizon Center (NH; East Fork Poplar Creek kilometer [EFK] 5.4) to the weekly difference in total mercury flux (g) between EFK 5.4 and Station 17.

\subsubsection{Bank Erosion Estimates}

Bank erosion is believed to be a key source of $\mathrm{HgT}$ and to a lesser extent MeHg to LEFPC, particularly during storm events when erosion rates are high. As referenced previously, a GPS-based, kayak-mounted, above-water, and underwater video mapping and electronic sensor system was used to survey stream bank and erosion conditions on LEFPC in March and July 2013 (Peterson et al. 2015). A modified BEHI score was determined from bank height, bank angle, surface cover, and riparian diversity information. The BEHI and NBS scores were used to estimate total BER and identify locations of high erosion and stream bank rescission using the North Carolina Piedmont Region Bank Erosion Prediction Curves (Doll 2003). The BER estimates were determined on an increment of about every 1 to $2 \mathrm{~m}$ as the kayak floated downstream. The estimated mass flux of bank soil (Fig. 38) entering the creek through bank erosion per $100 \mathrm{~m}$ reach (kilograms/year per $100 \mathrm{~m}$ ) was calculated using estimated BER values and bank heights measured during the kayak survey, while assuming an average bulk density of 1.25 for bank soils as determined by the mercury TD project. The estimated amount of bank soils entering each of the model reaches per year because of bank erosion is provided in Table 15.

Results of systematic bank sampling from the midpoint of the stream bank (conducted for the mercury TD project) along LEFPC from Station 17 to EFK 5.4 for $\mathrm{HgT}$ and MeHg are shown in Figs. 39 and 40, respectively. Also are shown on these figures for comparison are the maximum concentrations of select targeted sampling for $\mathrm{HgT}$ and $\mathrm{MeHg}$ in a laterally extensive, highly contaminated HRD that has been identified primarily in reaches EFK 23-20 and EFK 20-16. Vertical profiles of $\mathrm{HgT}$ and $\mathrm{MeHg}$ concentrations have been determined at several locations where the HRD is known to exist. Although a maximum concentration of $1,434 \mathrm{mg} / \mathrm{kg}$ in the center of one HRD has been detected (Southworth et al. 2010), the average across the HRD profiles from the top to the bottom of the bank is estimated to be $\sim 157 \mathrm{mg} / \mathrm{kg}$. This average concentration for the HRD profile was used in the estimate of HgT flux for bank erosion where the HRD is known to exist. 




Fig. 38. Estimated mass of soil entering East Fork Poplar Creek because of bank erosion per $100 \mathrm{~m}$ reach (kilograms/year per $100 \mathrm{~m}$ ) calculated using bank erosion rate values, bank heights measured during the kayak survey, and assuming an average bulk density of 1.25. (Notes: NOAA = National Oceanic and Atmospheric Administration; EFK = East Fork Poplar Creek kilometer.)

Table 15. Total mercury (HgT) and total methylmercury (MeHgT) flux estimates from bank erosion per modeling reach

\begin{tabular}{lccccc}
\hline Stream reach & $\begin{array}{c}\text { Bank erosion } \\
\text { (kg/year) }\end{array}$ & $\begin{array}{c}\text { HgT } \\
\text { concentration } \\
\text { (mg/kg) }\end{array}$ & $\begin{array}{c}\text { MeHgT } \\
\text { concentration } \\
(\mathbf{p g} / \mathbf{k g})\end{array}$ & $\begin{array}{c}\text { Sum of HgT } \\
\text { (kg/year) }\end{array}$ & $\begin{array}{c}\text { Sum of } \\
\text { MeHgT } \\
\text { (g/year) }\end{array}$ \\
\hline EFK 23 to 20 & 240,297 & 60 & 12.2 & 14.47 & 2.93 \\
EFK 20 to 16 & 220,066 & 80 & 7.4 & 17.54 & 1.63 \\
EFK 16 to 12 & 345,076 & 8.7 & 1.3 & 3.01 & .57 \\
EFK 12 to 5 & 301,657 & 11.9 & 1.9 & 3.59 & .58 \\
\hline Total & $1,107,095$ & NA & NA & 38.62 & 5.58 \\
\hline
\end{tabular}

Notes: EFK = East Fork Poplar Creek kilometer; NA = not applicable. 


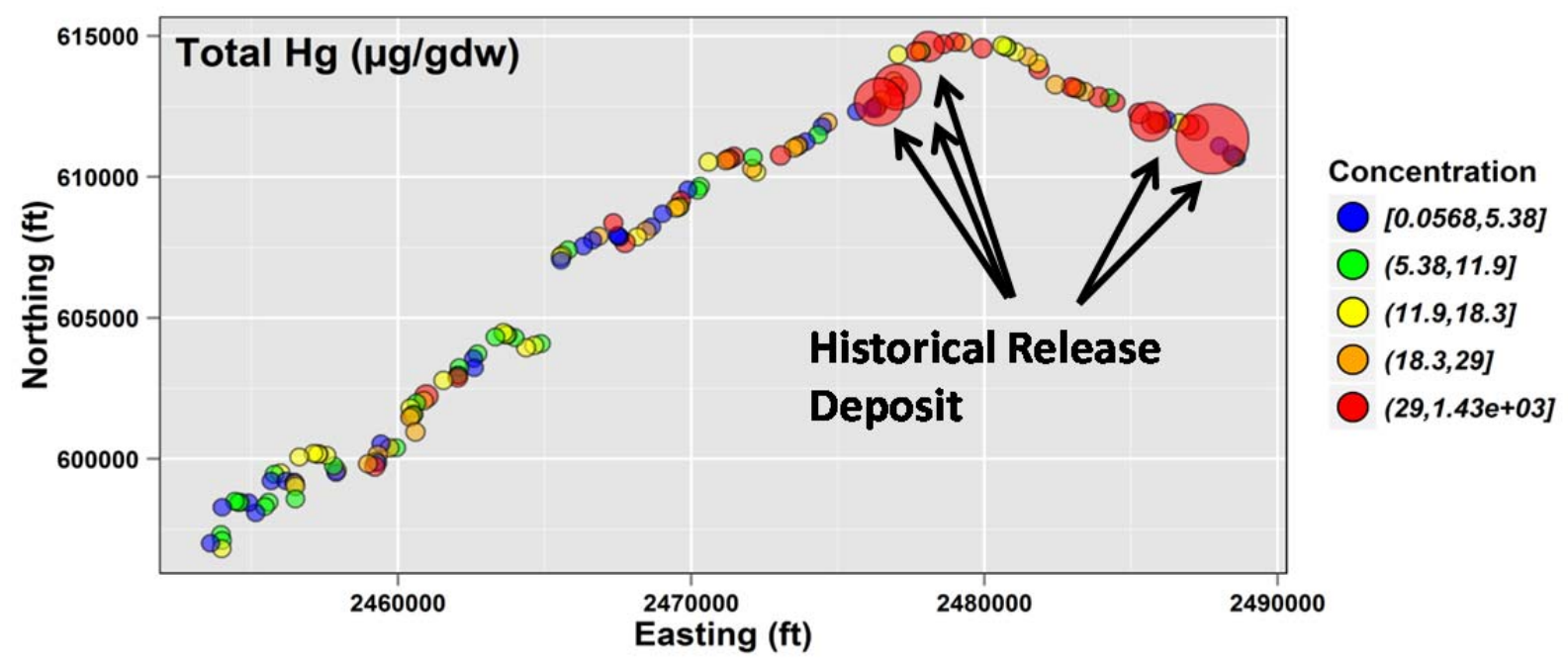

Fig. 39. Total mercury (HgT) bank soil sampling results from the center of the bank. Results of targeted sampling of $\mathrm{HgT}$ in highly contaminated historical release deposits are shown for comparison.

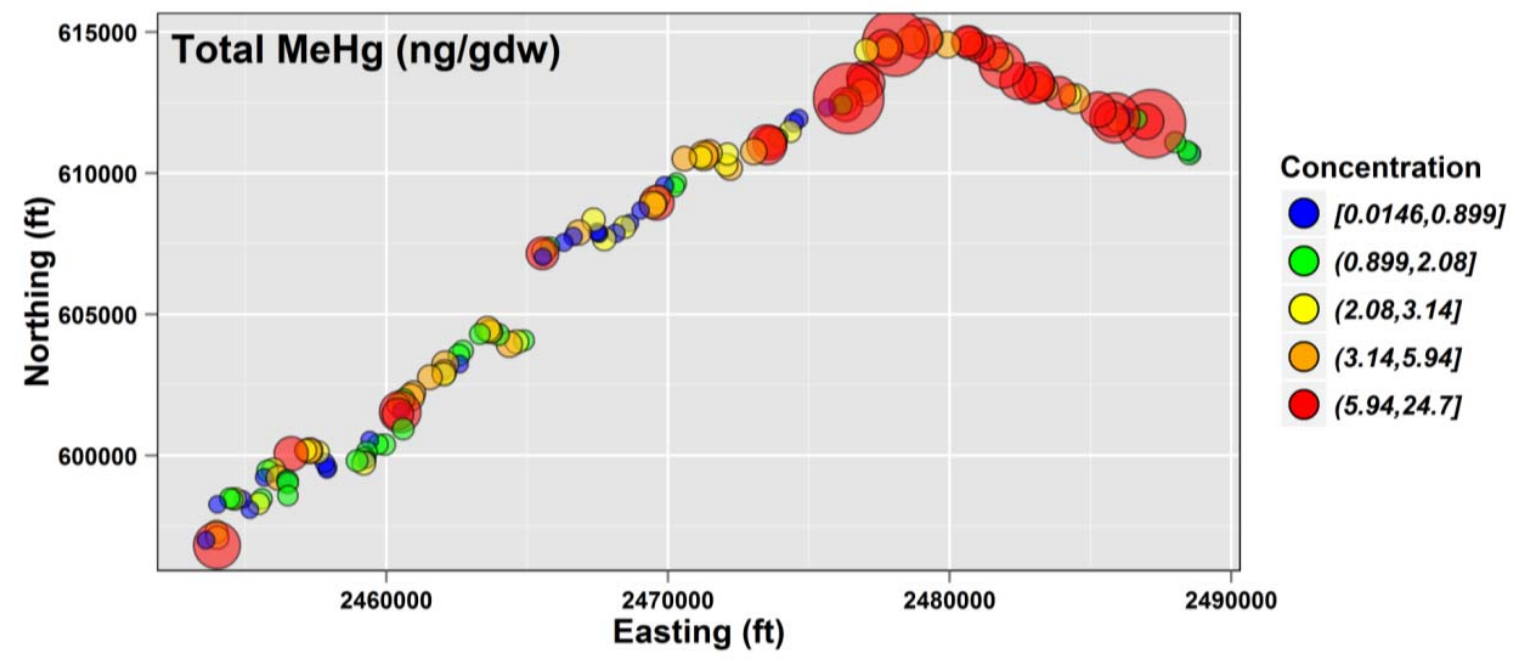

Fig. 40. Methylmercury (MeHg) bank soil sampling results from the center of the bank. Results of targeted sampling of $\mathrm{MeHg}$ in highly contaminated historical release deposits also are shown.

To estimate the flux of $\mathrm{HgT}$ and $\mathrm{MeHg}$ to the creek, GIS analysis tools were used to associate BER determined by the kayak analysis (i.e., the small 1-2 m increment data) with the closest bank sampling location and the concentrations of $\mathrm{HgT}$ and $\mathrm{MeHg}$ detected at that location. Where HRDs are known to exist (detailed mapping is still underway), the average profile concentration for the HRD was associated with BER and used to determine the flux of $\mathrm{HgT}$ and $\mathrm{MeHg}$. These estimates of $\mathrm{HgT}$ and $\mathrm{MeHg}$ fluxes were then summed to determine estimates for each $100 \mathrm{~m}$ incremental stream segment (Figs. 41 and 42, respectively, and Fig. 43), and then summed to obtain bank $\mathrm{HgT}$ and $\mathrm{MeHg}$ flux estimates for each modeling reach (Table 15). The calculated average concentration of $\mathrm{HgT}$ and $\mathrm{MeHg}$ in bank soils for each reach is also provided in Table 15. From this analysis, the total $\mathrm{HgT}$ and $\mathrm{MeHg}$ fluxes resulting from bank erosion for all the LEFPC reaches were estimated to be $38.6 \mathrm{~kg} /$ year and $5.6 \mathrm{~g} /$ year, respectively. However, it should be noted that there is significant uncertainty associated with these estimates. 


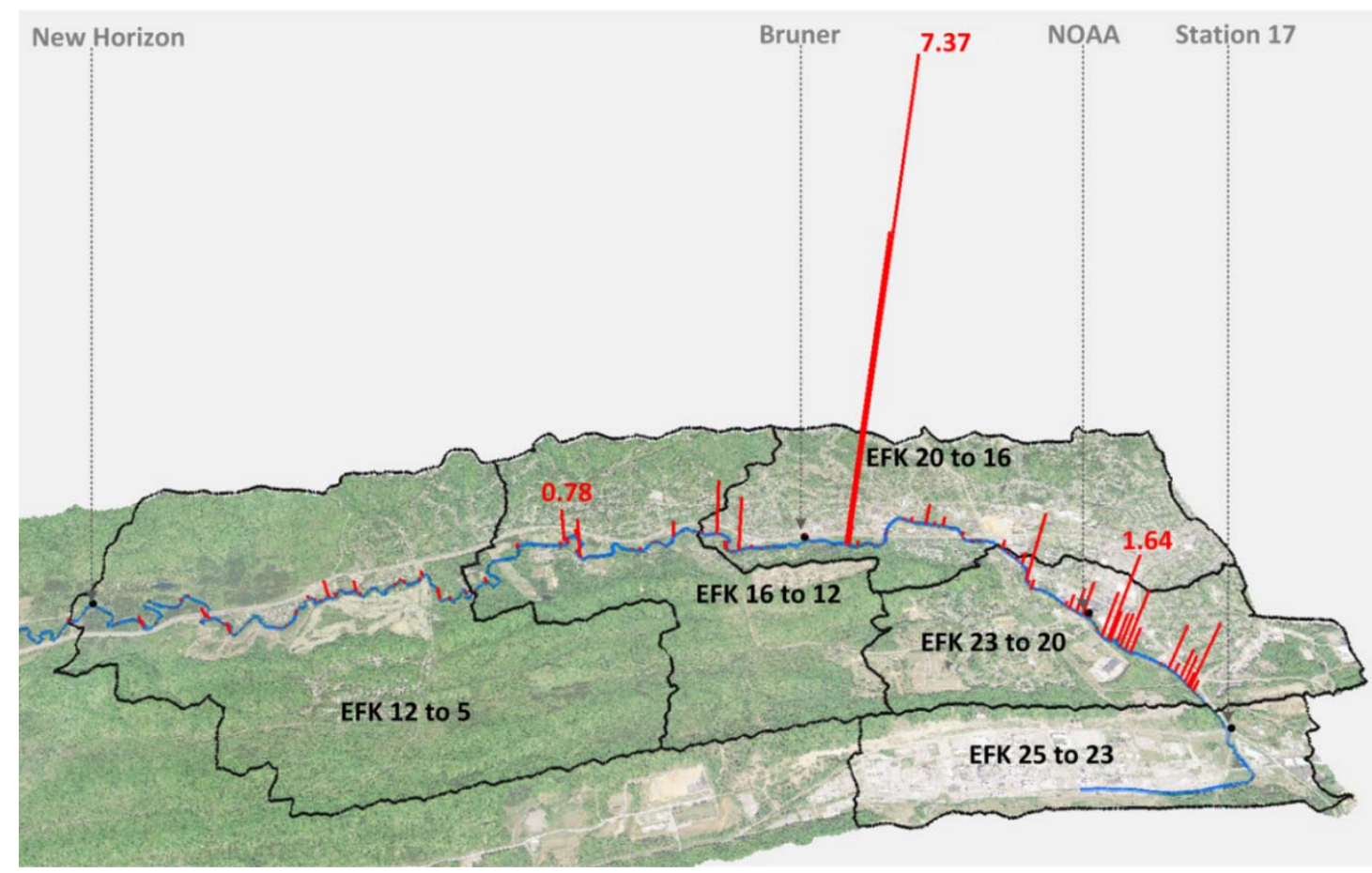

Fig. 41. Estimated total mercury flux per $100 \mathrm{~m}$ reach (kilograms/year per $100 \mathrm{~m}$ ) in East Fork Poplar Creek.(Notes: NOAA = National Oceanic and Atmospheric Administration; EFK = East Fork Poplar Creek kilometer.)

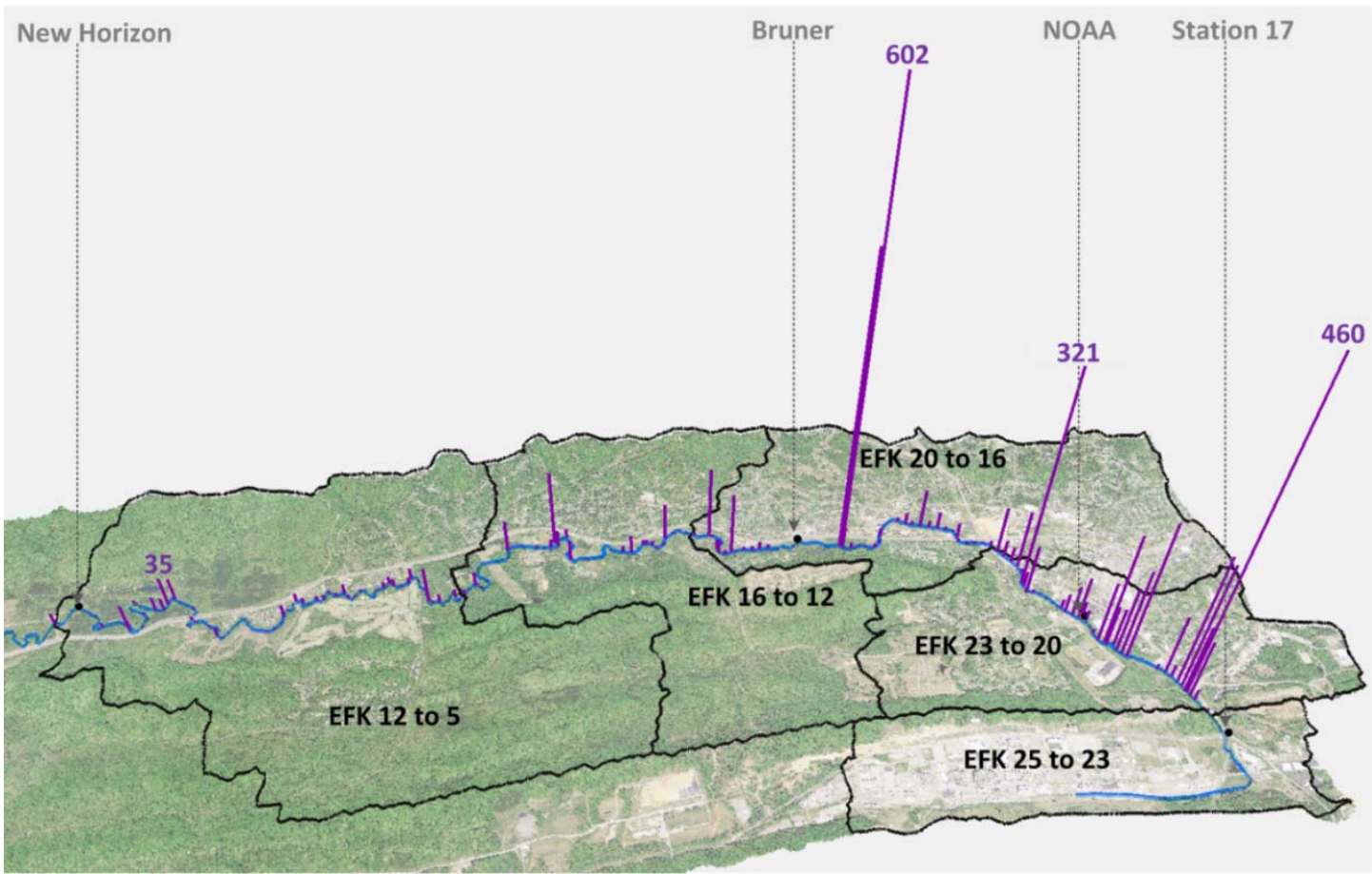

Fig. 42. Estimated methylmercury flux per 100-m reach (milligrams/year per $100 \mathrm{~m}$ ) in East Fork

Poplar Creek.(Notes: NOAA $=$ National Oceanic and Atmospheric Administration; EFK $=$ East Fork Poplar Creek kilometer.) 


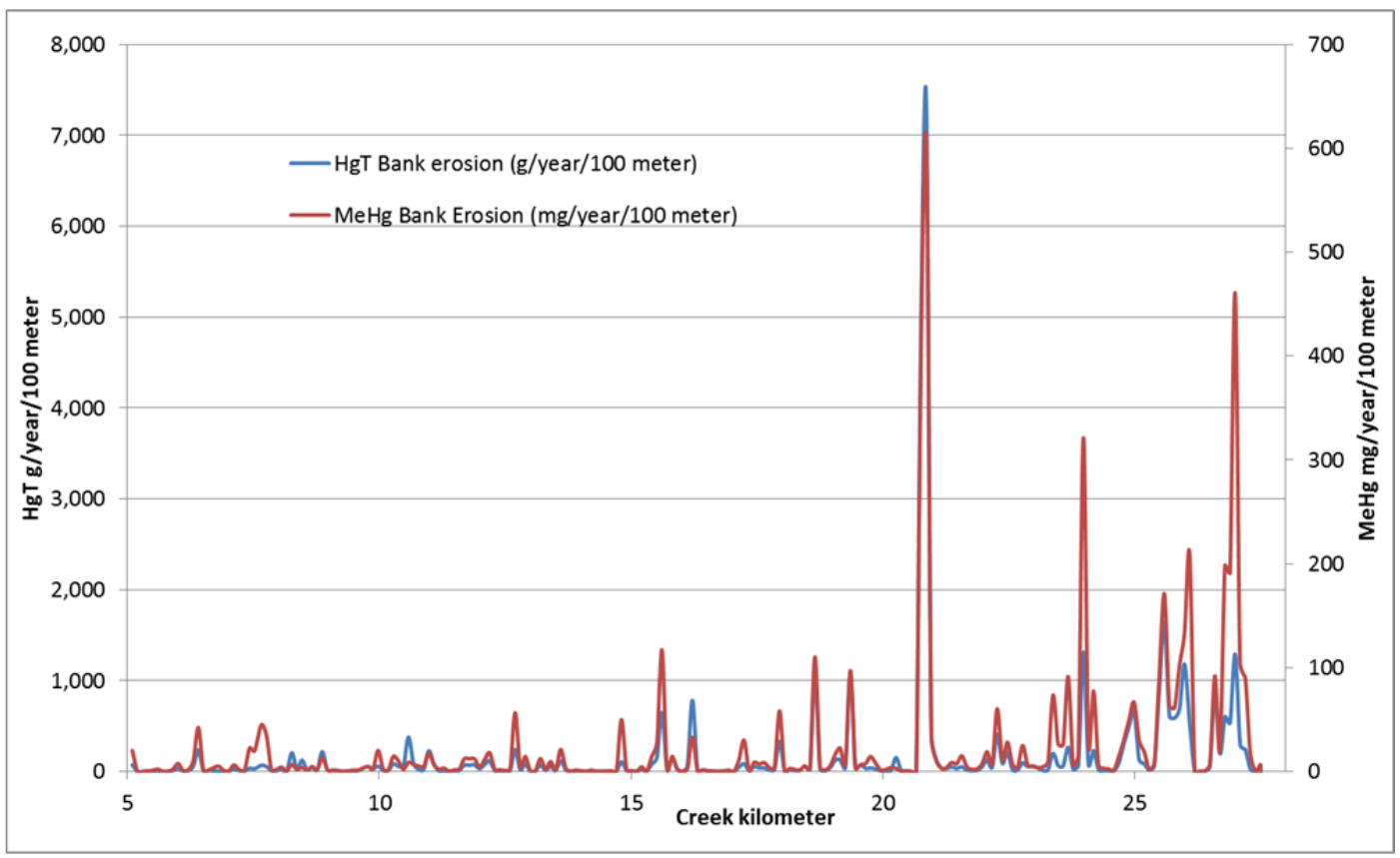

Fig. 43. Estimated total mercury (HgT) and methylmercury (MeHg) flux per $100 \mathrm{~m}$ reach.

For estimating monthly inputs to the model, it was assumed that there would be, on average for most years, greater erosion rates during wetter high-flow months (winter and spring) and also greater erosion during periods of alternating freezing and thawing (winter, and to a lesser extent, late fall and early spring) that would result in soil spalling. The average monthly stream flow and number of freezing days in a month was normalized, and the resulting monthly bank erosion input distribution for $\mathrm{HgT}$ and $\mathrm{MeHg}$ for each of the reaches is shown in Figs. 44 and 45, respectively. For these figures, the total of the HgT flux was assumed to be 0.7 times the estimated amount in Table 15 ( $\sim 26 \mathrm{~kg} /$ year). 


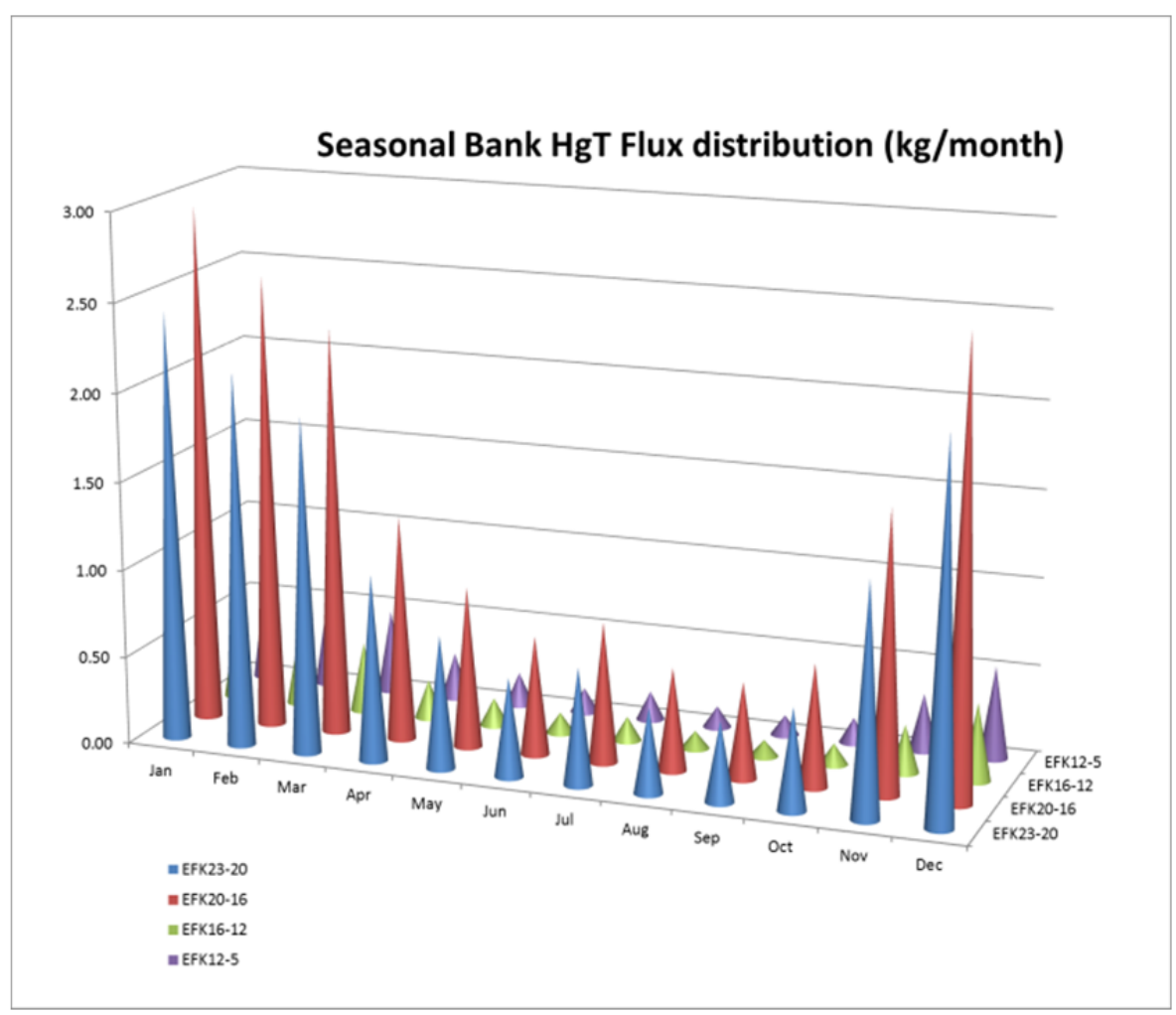

Fig. 44. Monthly distribution of total mercury (HgT) flux for each modeled stream reach. (Note: $\mathrm{EFK}=$ East Fork Poplar Creek kilometer.)

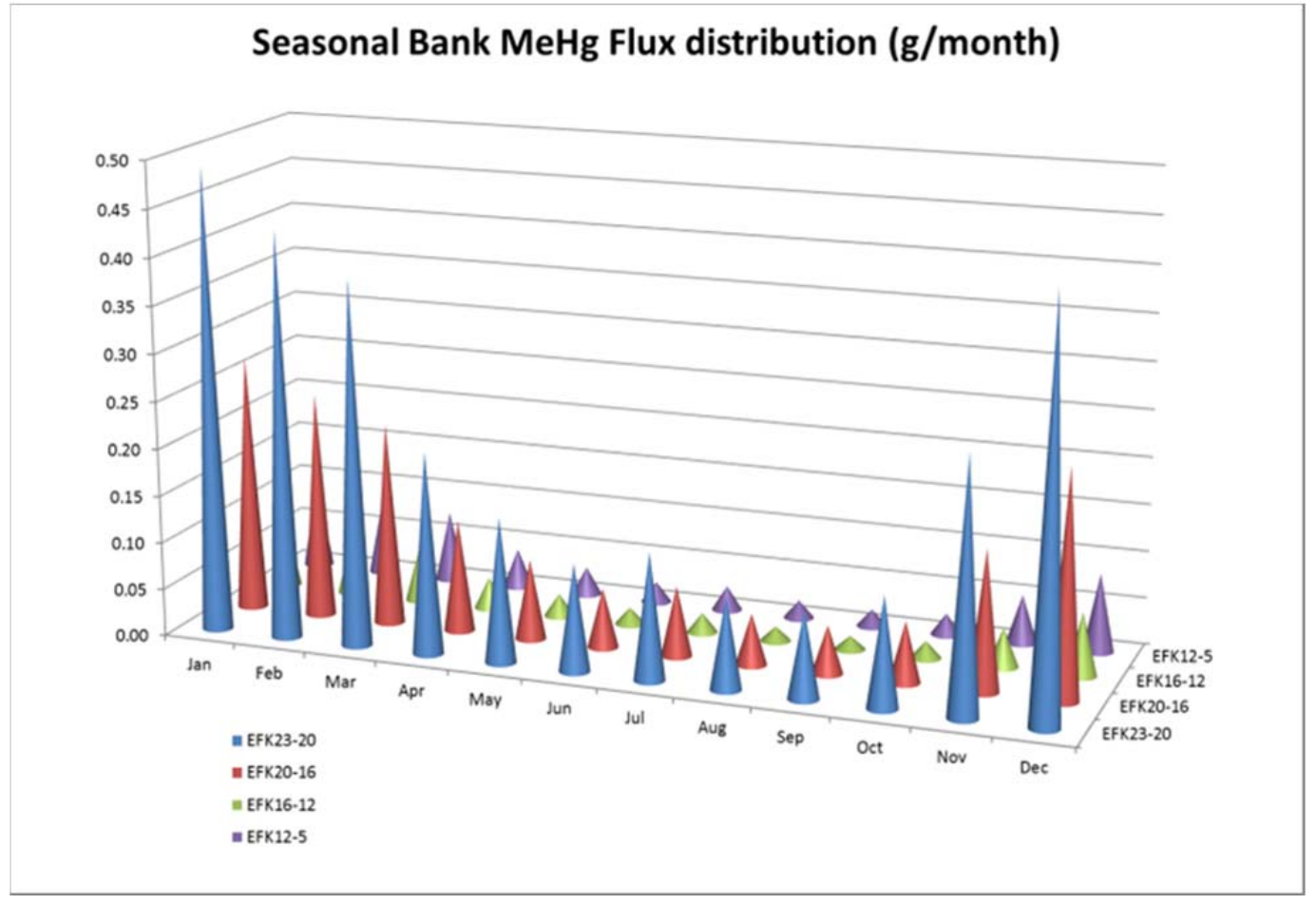

Fig. 45. Monthly distribution of methylmercury (MeHg) flux for each modeled stream reach. (Note: $\mathrm{EFK}=$ East Fork Poplar Creek kilometer.) 


\subsubsection{Floodplain Inputs-Overland Flow and Infiltration}

Figure 46 shows contours of HgT contamination in the LEFPC floodplain that were developed using historical and more recent floodplain sampling results, including the mercury TD bank sampling results. The areas of the floodplain that have been excavated during previous CERCLA actions were assumed to have been removed but recontaminated with low levels of $\mathrm{HgT}(\sim 4 \mathrm{mg} / \mathrm{kg}$ level). The extent of the contouring was clipped in GIS by the 500-year floodplain boundary. The total area of the floodplain is estimated to be approximately $616,000 \mathrm{~m}^{2}$ between Station 17 and EFK 5.4. The area of floodplain that falls within each contour interval for each stream reach is listed in Table 16. The estimated mass of HgT in the floodplain for selected contour intervals for each stream reach is shown in Table 17. The total mass of $\mathrm{HgT}$ in the floodplain is estimated to be $\sim 57,000 \mathrm{~kg}$, but there is much uncertainty with this estimate.

Precipitation falling on the floodplain area will do one of the following: (1) infiltrate vertically, potentially picking up mercury before reaching groundwater and slowly migrating laterally to LEFPC;

(2) run off, potentially picking up mercury contamination before entering LEFPC during storm events; or

(3) be lost to the atmosphere through ET. Annual rainfall averages $141 \mathrm{~cm} /$ year, and ET was estimated to be $\sim 80 \mathrm{~cm} /$ year in the Oak Ridge area (Wilson et al. 2001; Lutz, Mulholland, and Bernhardt 2012). A study by the US Geological Survey (1990), which included an assessment of recharge rates for East Tennessee watersheds, suggests that a recharge rate of $24 \mathrm{~cm} /$ year is reasonable for the EFPC watershed, leaving a total of $\sim 37 \mathrm{~cm} /$ year as runoff. Table 18 shows the estimated recharge volume in the floodplain for selected $\mathrm{HgT}$ contour intervals for each stream reach per year.

Estimates of mercury fluxes associated with floodplain infiltration and leaching - The amount of $\mathrm{HgT}$ leached when precipitation percolates through the contaminated floodplain is dependent on the volume of water leached through each concentration contour interval (Table 18), the assumed concentration of $\mathrm{HgT}$ in the floodplain soils for the different contour intervals (Table 16), and the partition coefficient $\left(K_{d}\right)$ between the water and soil. The $K_{d}$ used for this study was assumed to be $\sim 1,000,000 \mathrm{~L} / \mathrm{kg}$ based on Southworth et al. (2013). The estimated mass of HgT leached per year from selected HgT contour intervals for each stream reach is shown in Table 19. The total amount of HgT leached for the entire watershed was estimated to be only $\sim 8 \mathrm{~g} / \mathrm{year}$. The upper reaches of LEFPCEFK 23-20 and EFK 20-16 - had the greatest predicted amount of leaching because the highest concentrations of $\mathrm{HgT}$ were detected in the floodplain for these reaches. For the model input, it was assumed that HgT leaching occurs continuously and the estimated yearly $\mathrm{HgT}$ flux for each reach was distributed evenly across each monthly time step.

Measurements of the concentration of $\mathrm{MeHg}$ in floodplain sediments are limited. However, the ratio of $\mathrm{MeHg}$ to $\mathrm{HgT}$ in bank samples is approximately 0.00023 . If this ratio is the same in the floodplain, the total $\mathrm{MeHg}$ in the floodplain could be as high as $13 \mathrm{~kg}$. The soil-water $K_{d}$ for $\mathrm{MeHg}$ has been estimated to be $\sim 160,000 \mathrm{~L} / \mathrm{kg}$ (Southworth et al. 2013). Using these assumptions, the total amount of $\mathrm{MeHg}$ leached for the entire floodplain is only $\sim 11.4 \mathrm{mg} /$ year. However, samples from groundwater wells installed at EFK 5.4 and near the intersection of Mill Branch with LEFPC (see Chapter 3) have been observed to have a ratio of $\mathrm{MeHg}$ to $\mathrm{HgT}$ that is very high ( $\sim 0.15)$. Using a ratio of 0.15 for $\mathrm{MeHg}$ to $\mathrm{HgT}$ in groundwater, and the $\mathrm{HgT}$ estimates from Table 19, a flux of $\mathrm{MeHg}$ from floodplain leaching for the watershed is estimated to be as high as $1.2 \mathrm{~g} /$ year. Although floodplain leaching estimates are an area of uncertainty, the higher leaching estimate for $\mathrm{MeHg}$ was used in the model to be conservative. Table 20 shows the estimated mass of $\mathrm{MeHg}$ leached per year from the selected $\mathrm{HgT}$ floodplain contour intervals for each stream reach used in the model. For the model input, it was assumed that the leaching of $\mathrm{MeHg}$ occurs continuously and the estimated yearly flux of $\mathrm{MeHg}$ for each reach was distributed evenly across each monthly time step. 


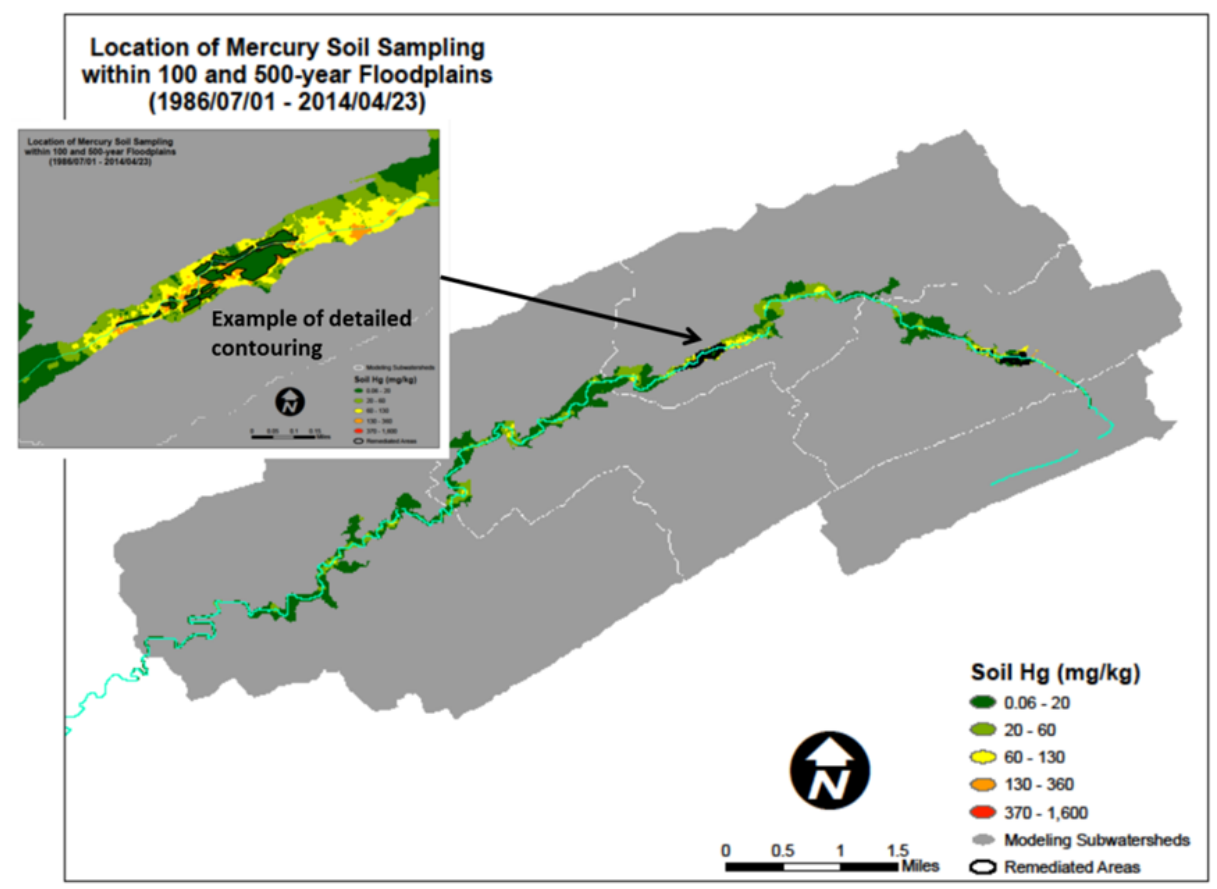

Fig. 46. Detailed floodplain concentration contouring used to estimate floodplain fluxes in East Fork Poplar Creek.

Table 16. Area of floodplain for selected total mercury contour intervals for each stream reach in East Fork Poplar Creek

\begin{tabular}{lrrrrrr}
\hline & \multicolumn{6}{c}{ Contaminated area (square meters) } \\
\cline { 2 - 7 }$\left(\begin{array}{c}\text { HgT } \\
(\mathbf{m g} / \mathbf{k g})\end{array}\right.$ & EFK 25-23 & EFK 23-20 & EFK 20-16 & EFK 16-12 & EFK 12-5 & $\begin{array}{c}\text { Average } \\
\text { concentration } \\
\text { (mg/kg) }\end{array}$ \\
\hline $0.0059-10$ & 6,675 & 40,253 & 50,274 & 22,050 & 21,875 & 4 \\
$10-50$ & 5,450 & 43,447 & 67,451 & 81,050 & 73,325 & 30 \\
$50-110$ & 400 & 35,625 & 75,350 & 28,425 & 16,725 & 80 \\
$110-210$ & - & 21,725 & 23,225 & 3,025 & 2,075 & 160 \\
$210-400$ & - & 5,450 & 3,300 & 350 & 100 & 305 \\
$400-1,600$ & - & 1,000 & 75 & - & - & 1,000 \\
\hline Total Area $\left(\mathbf{m}^{\mathbf{2}}\right)$ & $\mathbf{1 2 , 5 2 5}$ & $\mathbf{1 4 7 , 5 0 0}$ & $\mathbf{2 1 9 , 6 7 5}$ & $\mathbf{1 3 4 , 9 0 0}$ & $\mathbf{1 1 4 , 1 0 0}$ & $\mathbf{6 2 8 , 7 0 0}$ \\
\hline
\end{tabular}

Note: $\mathrm{EFK}=$ East Fork Poplar Creek kilometer. 
Table 17. Estimated mass of total mercury (HgT) in the floodplain (kg) for selected HgT contour intervals for each stream reach in East Fork Poplar Creek

\begin{tabular}{lccccc}
\hline \multicolumn{1}{c}{ HgT (mg/kg) } & EFK 25-23 & EFK 23-20 & EFK 20-16 & EFK 16-12 & EFK 12-5 \\
\hline $0.0059-10$ & 46 & 276 & 344 & 151 & 150 \\
$10-50$ & 280 & 2,232 & 3,465 & 4,164 & 3,767 \\
$50-110$ & 55 & 4,881 & 10,323 & 3,894 & 2,291 \\
$110-210$ & - & 5,953 & 6,364 & 829 & 569 \\
$210-400$ & - & 2,847 & 1,724 & 183 & 52 \\
$400-1,600$ & - & 1,713 & 128 & - & - \\
\hline Total mass (kg) & $\mathbf{3 8 1}$ & $\mathbf{1 7 , 9 0 0}$ & $\mathbf{2 2 , 3 4 8}$ & $\mathbf{9 , 2 2 1}$ & $\mathbf{6 , 8 2 9}$ \\
\hline
\end{tabular}

Notes: Mass mercury in each floodplain concentration range. EFK = East Fork Poplar Creek kilometer.

Table 18. Estimated recharge volume (cubic meter) for selected total mercury (HgT) contour intervals for each stream reach per year in East Fork Poplar Creek

\begin{tabular}{lccccc}
\hline $\begin{array}{c}\text { Recharge volume } \\
\text { HgT (mg/kg) }\end{array}$ & EFK 25-23 & EFK 23-20 & EFK 20-16 & EFK 16-12 & EFK 12-5 \\
\hline $0.0059-10$ & 1,602 & 9,661 & 12,066 & 5,292 & 5,250 \\
$10-50$ & 1,308 & 10,427 & 16,188 & 19,452 & 17,598 \\
$50-110$ & 96 & 8,550 & 18,084 & 6,822 & 4,014 \\
$110-210$ & - & 5,214 & 5,574 & 726 & 498 \\
$210-400$ & - & 1,308 & 792 & 84 & 24 \\
$400-1,600$ & - & 240 & 18 & - & - \\
\hline Total recharge $\left.\mathbf{( m}^{\mathbf{3}}\right)$ & $\mathbf{3 , 0 0 6}$ & $\mathbf{3 5 , 4 0 0}$ & $\mathbf{5 2 , 7 2 2}$ & $\mathbf{3 2 , 3 7 6}$ & $\mathbf{2 7 , 3 8 4}$ \\
\hline
\end{tabular}

Note: $\mathrm{EFK}=$ East Fork Poplar Creek kilometer.

Table 19. Estimated mass of total mercury (HgT) leached (mg) per year from selected HgT contour intervals for each stream reach in East Fork Poplar Creek

\begin{tabular}{lccccc}
\hline \multicolumn{1}{c}{ HgT (mg/kg) } & EFK 25-23 & EFK 23-20 & EFK 20-16 & EFK 16-12 & EFK 12-5 \\
\hline $0.0059-10$ & 6 & 39 & 48 & 21 & 21 \\
$10-50$ & 39 & 313 & 486 & 584 & 528 \\
$50-110$ & 8 & 684 & 1,447 & 546 & 321 \\
$110-210$ & 0 & 834 & 892 & 116 & 80 \\
$210-400$ & 0 & 399 & 242 & 26 & 7 \\
$400-1,600$ & 0 & 240 & 18 & 0 & 0 \\
\hline HgT leached (mg) & $\mathbf{5 3}$ & $\mathbf{2 , 5 0 9}$ & $\mathbf{3 , 1 3 2}$ & $\mathbf{1 , 2 9 2}$ & $\mathbf{9 5 7}$ \\
\hline
\end{tabular}

Notes: Mass HgT through infiltration $K_{d}=1,000,000$. EFK $=$ East Fork Poplar Creek kilometer. 
Table 20. Estimated mass of methylmercury (MeHg) leached (milligrams) per year from selected total mercury contour intervals for each stream reach in East Fork Poplar Creek

\begin{tabular}{lccccc}
\hline \multicolumn{1}{c}{ MeHg (mg/kg) } & EFK 25-23 & EFK 23-20 & EFK 20-16 & EFK 16-12 & EFK 12-5 \\
\hline $0.0059-10$ & 1.0 & 5.8 & 7.2 & 3.2 & 3.2 \\
$10-50$ & 5.9 & 46.9 & 72.8 & 87.5 & 79.2 \\
$50-110$ & 1.2 & 102.6 & 217.0 & 81.9 & 48.2 \\
$110-210$ & 0 & 125.1 & 133.8 & 17.4 & 12.0 \\
$210-400$ & 0 & 59.8 & 36.2 & 3.8 & 1.1 \\
$400-1,600$ & 0 & 36.0 & 2.7 & 0 & 0 \\
\hline MeHg leached (mg) & $\mathbf{8 . 0}$ & $\mathbf{3 7 6 . 3}$ & $\mathbf{4 6 9 . 8}$ & $\mathbf{1 9 3 . 8}$ & $\mathbf{1 4 3 . 6}$ \\
\hline
\end{tabular}

Notes: Mass MeHg through infiltration based on ratio of MeHg to total mercury in EFK 5.4/Mill Branch groundwater wells = 0.15. $\mathrm{EFK}=$ East Fork Poplar Creek kilometer.

Estimates of mercury fluxes associated with floodplain runoff-Southworth et al. (2010) describes the results of floodplain runoff measurements at EFK 5.4 and near the NOAA offices for several storms. From these studies, it was estimated that the average $\mathrm{HgT}$ and $\mathrm{MeHg}$ in runoff from the floodplain are $2,044 \mathrm{ng} / \mathrm{L}$ and $0.31 \mathrm{ng} / \mathrm{L}$, respectively. The average TSS concentration was estimated to be $107 \mathrm{mg} / \mathrm{l}$, with only about $10 \%$ of the flux being in the dissolved form. The HgT concentration on TSS is estimated to be $\sim 17.2 \mathrm{mg} / \mathrm{kg}$. As previously noted, it was estimated that there is $\sim 37 \mathrm{~cm} /$ year runoff from the floodplain. Although runoff is not observed at all locations on the floodplain, it is assumed that runoff occurs on $100 \%$ of the floodplain surface to be conservative. Even using these conservative assumptions, only $0.47 \mathrm{~kg} /$ year of $\mathrm{HgT}$ and $71 \mathrm{mg} /$ year of $\mathrm{MeHg}$ are estimated to originate from floodplain runoff. The monthly fluxes from surface runoff were assumed proportional to the average monthly rainfall.

\subsubsection{Instream IHg and MeHg processes}

Sampling of LEFPC by several different programs (e.g., EM's Water Resources Restoration Program), mercury SFA, mercury TD, etc.) during base flow and stormflow conditions has provided new insights into instream IHg deposition and mobilization processes and $\mathrm{MeHg}$ production processes. EM (OREIS data) has conducted biannual sampling of $\mathrm{HgT}$ and $\mathrm{MeHg}$ at times that are representative of summer and winter base flow conditions at four locations along EFPC (EFKs 6.3, 13.8, 18.2, and 24.4). Figures 47 and 48 show seasonal and downstream concentration trends for the period of 2007-14 for the four sampling locations for $\mathrm{HgT}$ and $\mathrm{MeHg}$, respectively. The results of averaging the data from each sampling location on a seasonal basis are shown in Figs. 49 and 50 for $\mathrm{IHg}$ and $\mathrm{MeHg}$, respectively. Estimates of the average flows in June and December, when these samples were collected, were used to estimate the flux of $\mathrm{HgT}$ and $\mathrm{MeHg}$ at each of the sampling locations on LEFPC (Figs. 51 and 52, respectively).

This series of figures shows that both $\mathrm{IHg}$ and $\mathrm{MeHg}$ base flow concentrations can be over four times higher in the summer than the winter, but the concentration trends from upstream to downstream for $\mathrm{IHg}$ and $\mathrm{MeHg}$ are reversed. The downstream concentration of $\mathrm{IHg}$ decreases in both the summer and winter, but at a much lower rate in summer. The concentration decreases much more between EFK 24.4 and 18.2 than it does at locations farther downstream. However, the flux of $\mathrm{HgT}$ in summer increases in a downstream direction, whereas it decreases initially in winter and levels out farther downstream. The $\mathrm{HgD}$ concentrations are very similar in winter and summer, suggesting the seasonal differences are related primarily to changes in HgP. It also has been observed that LEFPC tends to be cloudier and have more particulate matter in the summer. Higher biological activity in the summer, including agitation and mobilization of creek sediments (bioturbation), may be the cause of that seasons' higher HgP 
concentrations. A bioturbation factor is therefore included in the model for the warmer months, when biological activity is expected to be greater, to account for this increased seasonal flux of $\mathrm{HgT}$.

The decrease in concentration and flux in the winter between EFK 24.4 and 18.2 probably is related to the higher $\mathrm{HgD}$ fraction routinely observed in UEFPC closer to Y-12. This $\mathrm{HgD}$ phase appears to be unstable, partitioning out of the dissolved phase and becoming attached to stream sediments. A deposition factor was added to the model to account for this phenomenon. Although the downstream flux of HgT decreases in winter and increases in summer, the average flux for the year does not appear to be much different. In other words, despite the seasonal variations, the average annual base flow flux at Station 17 generally equals the base flow flux at EFK 5.4.

Unlike IHg, MeHg concentrations increase downstream under base flow conditions in summer and are relatively constant in winter. The fraction of dissolved $\mathrm{MeHg}$ increases significantly in the summer in a downstream direction. The flux of $\mathrm{MeHg}$ increases from upstream to downstream in both summer and winter, but the increase in flux in summer is greater than that in winter, suggesting more net methylation takes place in the warm summer months when biological growth and activity is the greatest (Desrosiers, Planas, and Mucci 2006). The increase in flux suggests that there is substantial net in-stream production of $\mathrm{MeHg}$ in EFPC related to biological activity. Although demethylation processes also are thought to be occurring in the EFPC system, methylation processes appear to be dominant, and for the purposes of this study, we considered and calculated only the net methylation rates (i.e., total methylation rate minus the demethylation rate). Based on recent studies conducted on the mercury TD project (Olsen and Brooks 2015) instream MeHg production and increased base flow flux in summer and winter are believed to be at least partially related to the growth and methylation associated with periphyton that grow on rocks, logs, detritus, and other surfaces within the stream. Other researchers including Cleckner et al. (1999); Acha, Hintelmann, and Yee (2011); Huguet et al. (2010); Correia, Miranda, and Guimaraes (2012); and Hamelin, Planas, and Amyot (2015) also have observed and measured methylation rates associated with periphyton activity. Recently, Hamelin, Planas, and Amyot (2015) estimated net periphyton methylation rates as high as $200 \mathrm{ng} / \mathrm{m}^{2}$ per day in a shallow fluvial lake located in Quebec, Canada.

The net instream methylation and $\mathrm{MeHg}$ production factors have been included in the model to account for undifferentiated biologically mediated $\mathrm{MeHg}$ production. Based on the data presented in Fig. 52, it was possible to estimate the amount of $\mathrm{MeHg}$ that is produced and enters the water column within each stream reach under typical base flow conditions. Figure 53 shows the estimated monthly instream $\mathrm{MeHg}$ production rate for each stream reach with increased production in the summer and in a downstream direction. Knowing the stream widths determined from the kayak surveys enabled the calculation of summer and winter methylation rates per square meter (unit) of stream bed for each reach (Table 21). As expected, the undifferentiated methylation rates per unit of stream bed that were estimated are highest in downstream reaches in both summer and winter, but the estimated summer rates (up to $285 \mathrm{ng} / \mathrm{m}^{2} \mathrm{per}$ day) are substantially greater than the winter rates (up to $60 \mathrm{ng} / \mathrm{m}^{2}$ per day). The estimated summer rates are higher than but similar to the rates estimated by Hamelin, Planas, and Amyot (2015) for periphyton. 


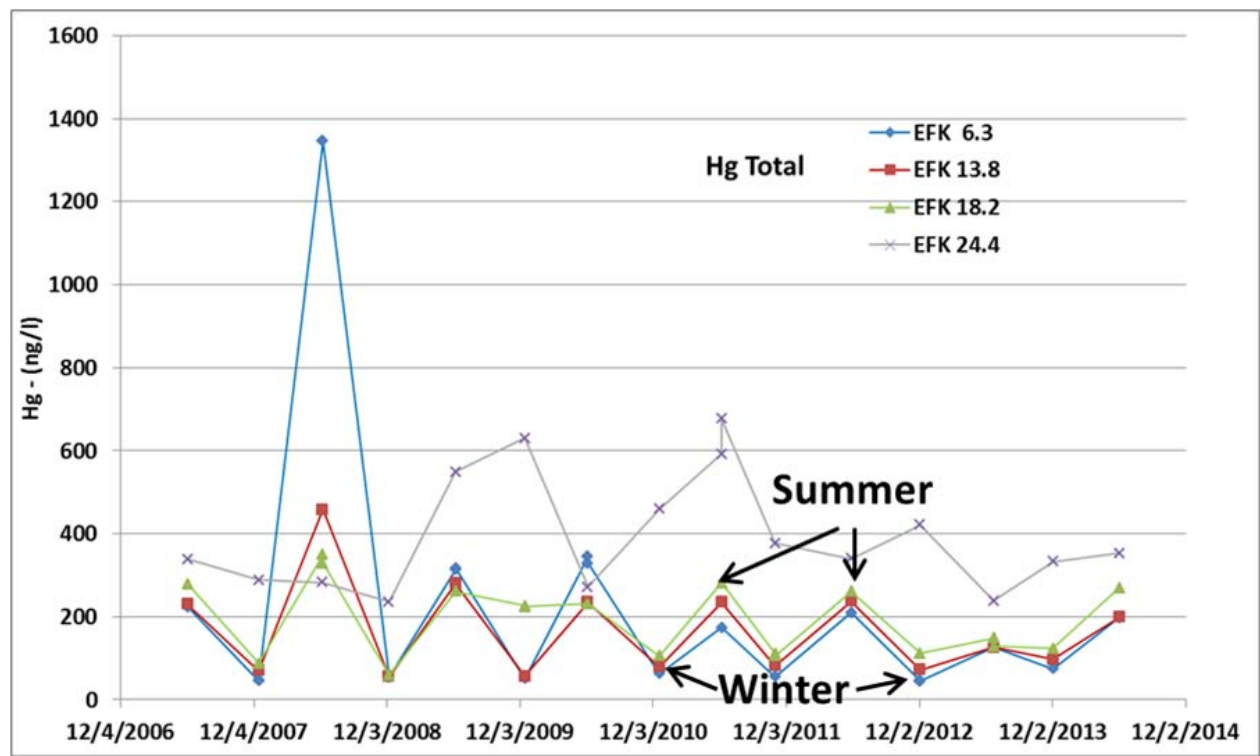

Fig. 47. Biannual total mercury (HgT) sampling at four locations along East Fork Poplar Creek in summer and winter showing seasonal and upstream to downstream trends.

(Note: EFK = East Fork Poplar Creek kilometer.)

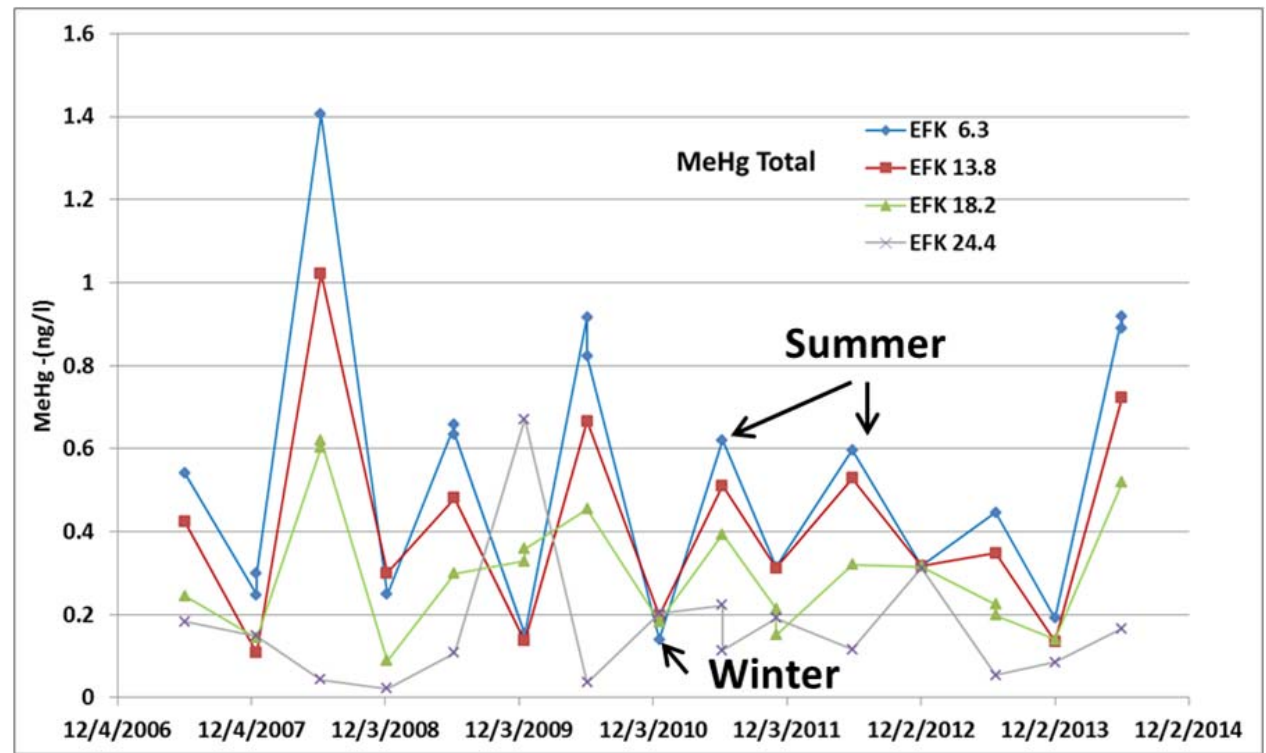

Fig. 48. Biannual total methylmercury (MeHgT) sampling at four locations along East Fork Poplar Creek in summer and winter showing seasonal and upstream to downstream trends.

(Note: EFK = East Fork Poplar Creek kilometer.) 


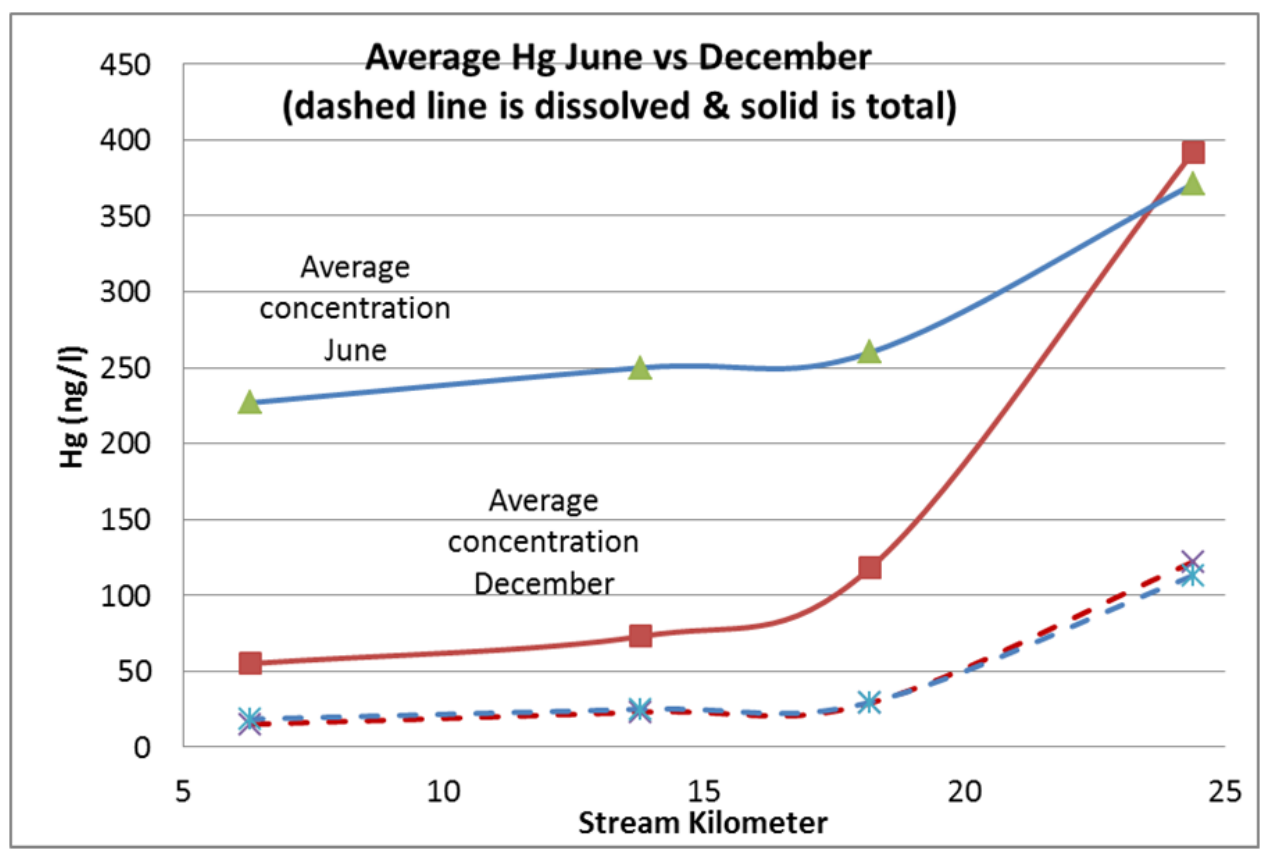

Fig. 49. Seasonal averages for 2007-14 base flow samples show significant differences in inorganic mercury concentrations from the upstream to downstream East Fork Poplar Creek sampling locations in warm months (June) compared with cold months (December).

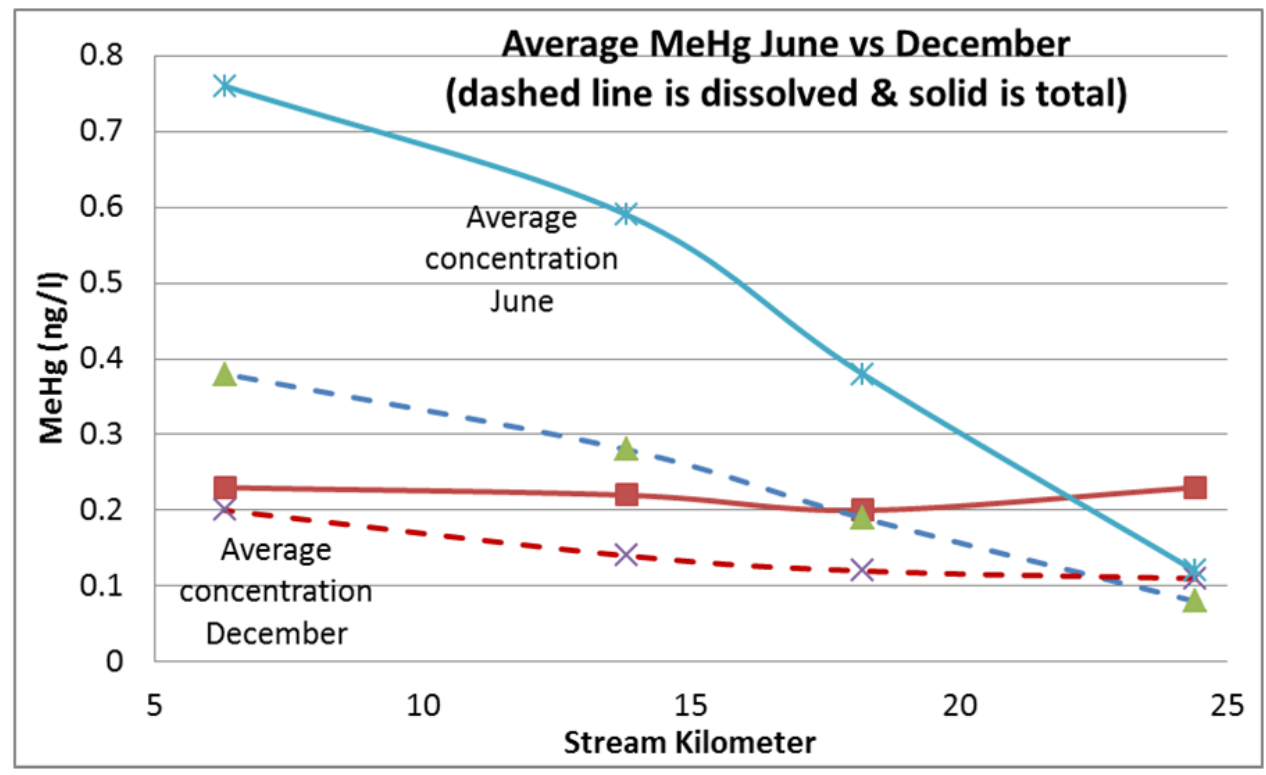

Fig. 50. Seasonal averages for 2007-14 base flow samples show significant differences in methylmercury concentrations from upstream to downstream East Fork Poplar Creek sampling locations in warm months (June) compared with cold months (December). 


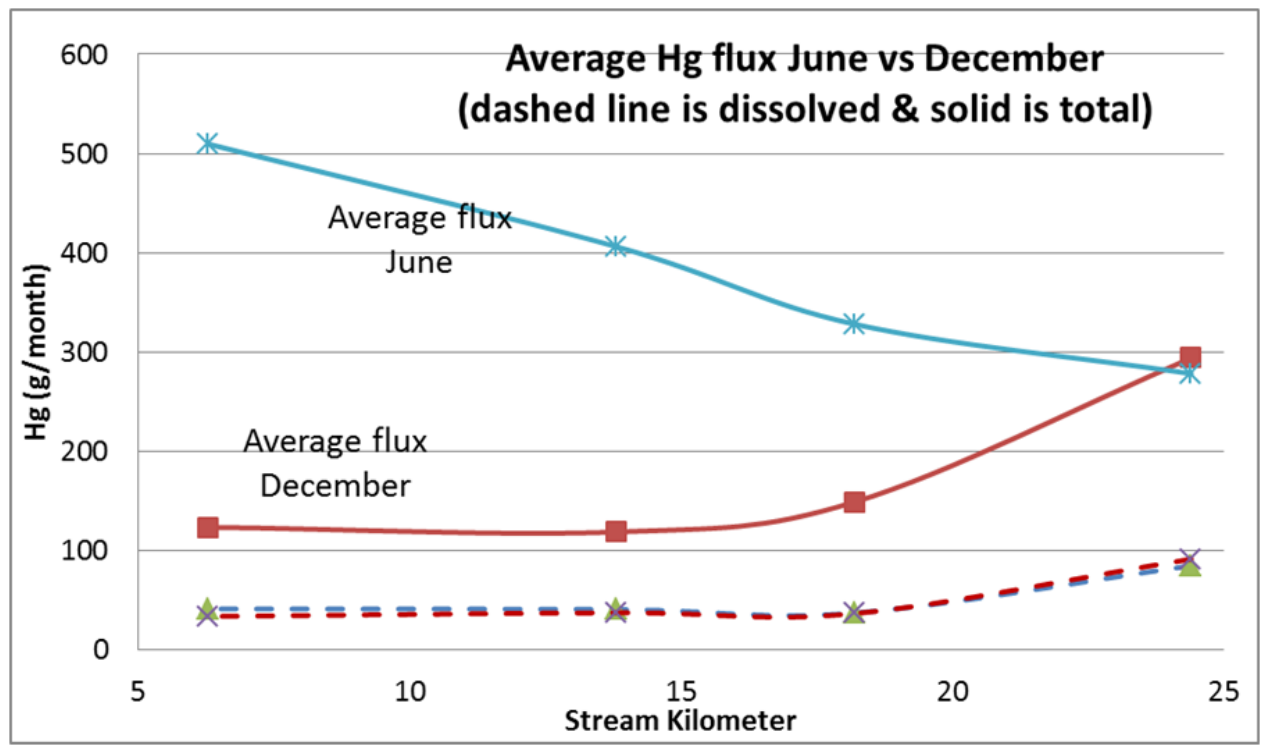

Fig. 51. Seasonally averaged flux estimates for 2007-14 base flow samples show significant differences in inorganic mercury fluxes on East Fork Poplar Creek in warm months (June) versus cold months (December).

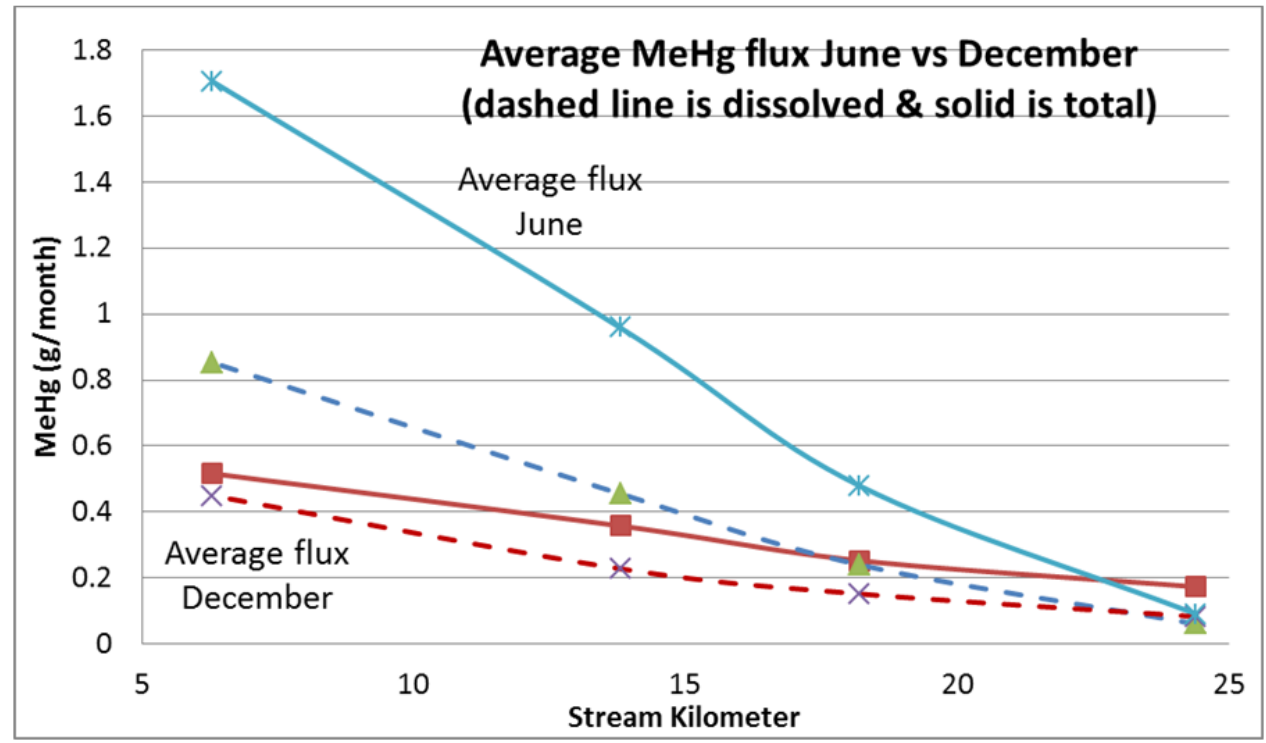

Fig. 52. Seasonally averaged flux estimates for 2007-14 base flow samples show significant differences in methylmercury fluxes on East Fork Poplar Creek in warm months (June) versus cold months (December). 


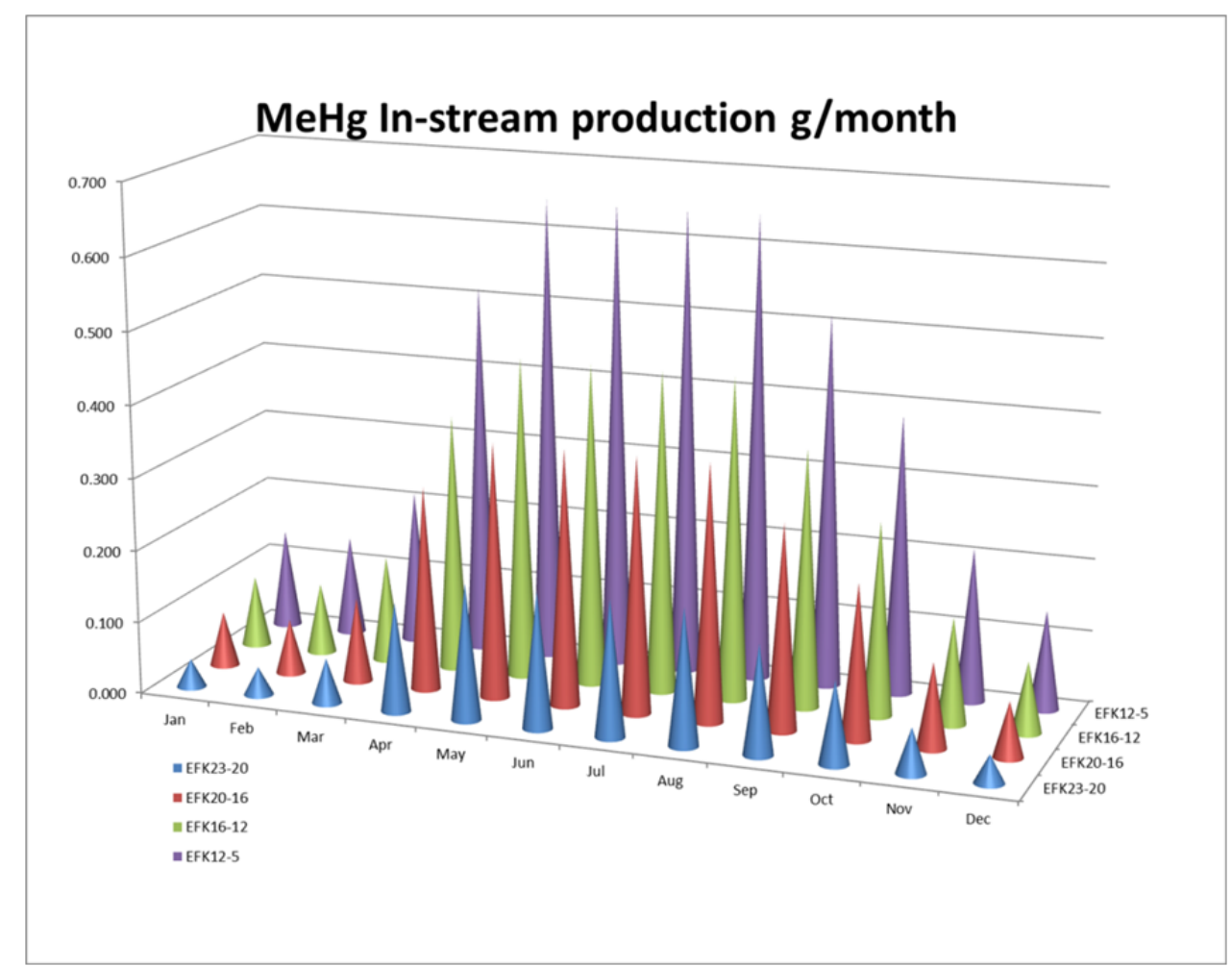

Fig. 53. Monthly instream methylmercury production by stream reach showing increased production downstream and in the summer. (Note: EFK = East Fork Poplar Creek kilometer.)

Table 21. Estimated instream methylation rates $\left(\mathrm{ng} / \mathrm{m}^{2}\right.$ per day) based on Fig. 50 data and stream geometry determined from the kayak survey of East Fork Poplar Creek

\begin{tabular}{ccc}
\hline Stream reach & $\begin{array}{c}\text { Summer rates } \\
\left(\mathbf{n g} / \mathbf{m}^{\mathbf{2}} \text { per day }\right)\end{array}$ & $\begin{array}{c}\text { Winter rates } \\
\left(\mathbf{n g} / \mathbf{m}^{2} \text { per day }\right)\end{array}$ \\
\hline EFK 12-5 & 284.53 & 60.45 \\
EFK 16-12 & 259.37 & 56.90 \\
EFK 20-16 & 214.07 & 45.76 \\
EFK 23-20 & 168.77 & 34.62 \\
EFK 25-23 & 168.77 & 34.62 \\
\hline
\end{tabular}

Note: $\mathrm{EFK}=$ East Fork Poplar Creek kilometer.

Mathews et al. (2013) investigated the relationship of aqueous mercury concentrations in several Oak Ridge streams to the concentration of mercury detected in fish tissue (Fig. 54). They postulate that for Oak Ridge streams, the aqueous mercury concentration has to decrease to $\sim 20 \mathrm{ng} / \mathrm{L}$ before the mercury concentration in fish tissue will fall below the regulatory standard of $0.3 \mathrm{mg} / \mathrm{kg}$. Their data also show that the concentration of mercury in fish tissue vacillates between 0.6 and $1.3 \mathrm{mg} / \mathrm{kg}$ until aqueous mercury concentrations reach $<200 \mathrm{ng} / \mathrm{L}$ and then decreases. The data suggest that the $\mathrm{MeHg}$ available for biological uptake does not change much until aqueous concentrations get below $200 \mathrm{ng} / \mathrm{L}$. Measurements of $\mathrm{HgT}$ and $\mathrm{MeHg}$ concentrations in periphyton from several streams in the United States by Bell and Scudder (2007) also seem to indicate that HgT in the LEFPC stream system will have to get below a threshold level before the $\mathrm{MeHg}$ concentration in periphyton will decrease substantially. The LEFPC model therefore assumes that methylation rates are not impacted (i.e., stay at $100 \%$ ) until aqueous 
mercury concentrations get below a threshold value, at which point the concentrations are assumed to decrease linearly to zero. The threshold value can be adjusted in the model, but for most runs, it is set to $200 \mathrm{ng} / \mathrm{L}$.

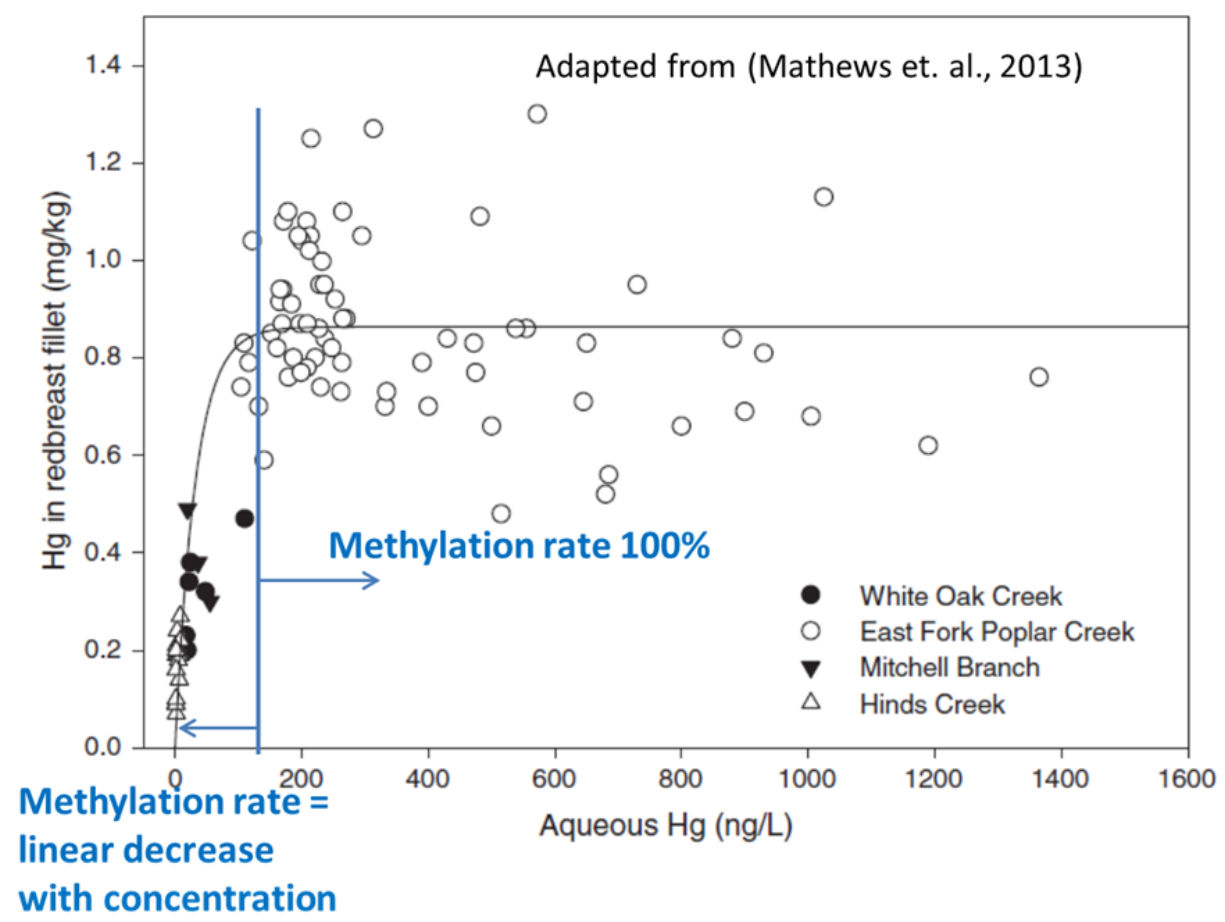

Fig. 54. Relationship of aqueous mercury concentrations in Oak Ridge streams to the concentration of mercury in fish tissue. For the LEFPC model, it is assumed that methylation rates are not impacted (i.e., stay at $100 \%$ ) until aqueous mercury concentrations get below a threshold, than the concentrations are assumed to decrease linearly to zero. (Adapted from: Mathews, T., G. Southworth, M. Peterson, W. Roy, R. Ketelle, C. Valentine, and S.

Gregory. 2013. "Decreasing Aqueous Mercury Concentrations to Achieve Safe Levels in Fish: Examining the Water-Fish Relationship in Two Point-Source Contaminated Streams." Science of the Total Environment 443:836843.)

\subsubsection{Estimates of Mercury Concentration on Total Suspended Solids}

The concentration of HgT associated with TSS is used in the model as an indicator of the concentration of $\mathrm{HgT}$ that could be associated with stream sediments and is impacting concentrations of mercury in periphyton available for methylation. The concentration of HgT on TSS at any point along the creek is impacted by the TSS concentration entering at Station 17, the concentration of $\mathrm{HgT}$ on bank sediments (Table 15) entering the creek, the concentration of TSS in floodplain runoff ( $\sim 17 \mathrm{mg} / \mathrm{kg})$, and the amount of clean TSS that enters the system because of runoff from uncontaminated portions of the LEFPC watershed. This concept of clean and contaminated TSS inputs by stream reach is illustrated in Fig. 55 . As these inputs of mercury to the TSS-Hg balance are reduced by management activities, the HgT concentration of TSS should change accordingly. For example, if bank erosion is decreased, the HgT concentration on creek TSS also is likely to decrease downstream compared with current conditions. It was estimated that, on average, approximately 3,469,000 kg/year of TSS exits the watershed at EFK 5.4, of which $\sim 316,000 \mathrm{~kg} /$ year enters from Station $17 ; 775,000 \mathrm{~kg} /$ year enters from bank erosion; 24,000 $\mathrm{kg} /$ year enters from floodplain runoff; and 2,353,000 kg/year is clean TSS entering the creek system. Using these estimates of the inputs of $\mathrm{HgT}$ fluxes associated with TSS, it is possible to estimate the concentration of HgT on TSS in each of the model reaches (Table 22). For comparison, the concentration 
of HgT on TSS estimated from mercury SFA creek grab sampling data also is shown in Table 22. There was excellent agreement between the team's method of estimating TSS HgT concentrations based on TSS flux components and the mercury SFA creek measurements.

Table 22. Estimates of the concentration ( $\mathrm{mg} / \mathrm{kg}$ ) of total mercury (HgT) on total suspended solids (TSS) at various East Fork Poplar Creek locations

\begin{tabular}{lccc}
\hline \multicolumn{2}{c}{ Based on TSS concentration and fluxes } & \multicolumn{2}{c}{ Based on mercury SFA measurements } \\
\hline \multicolumn{1}{c}{ Creek reach } & $\begin{array}{c}\text { TSS concentration } \\
\text { (mg/kg) }\end{array}$ & Creek location & $\begin{array}{c}\text { TSS concentration } \\
\text { (mg/kg) }\end{array}$ \\
\hline Station 17 & 80 (input factor) & NA & NA \\
EFK 23-20 & 46 & EFK 22 & 55 \\
EFK 20-16 & 36 & EFK 17.8 & 36 \\
EFK 16-12 & 25 & EFK 13.8 & 25 \\
EFK 12-5 & 17 & EFK 5 & 17 \\
\hline
\end{tabular}

Notes: SFA = Science Focus Area; NA = not applicable; EFK = East Fork Poplar Creek kilometer.

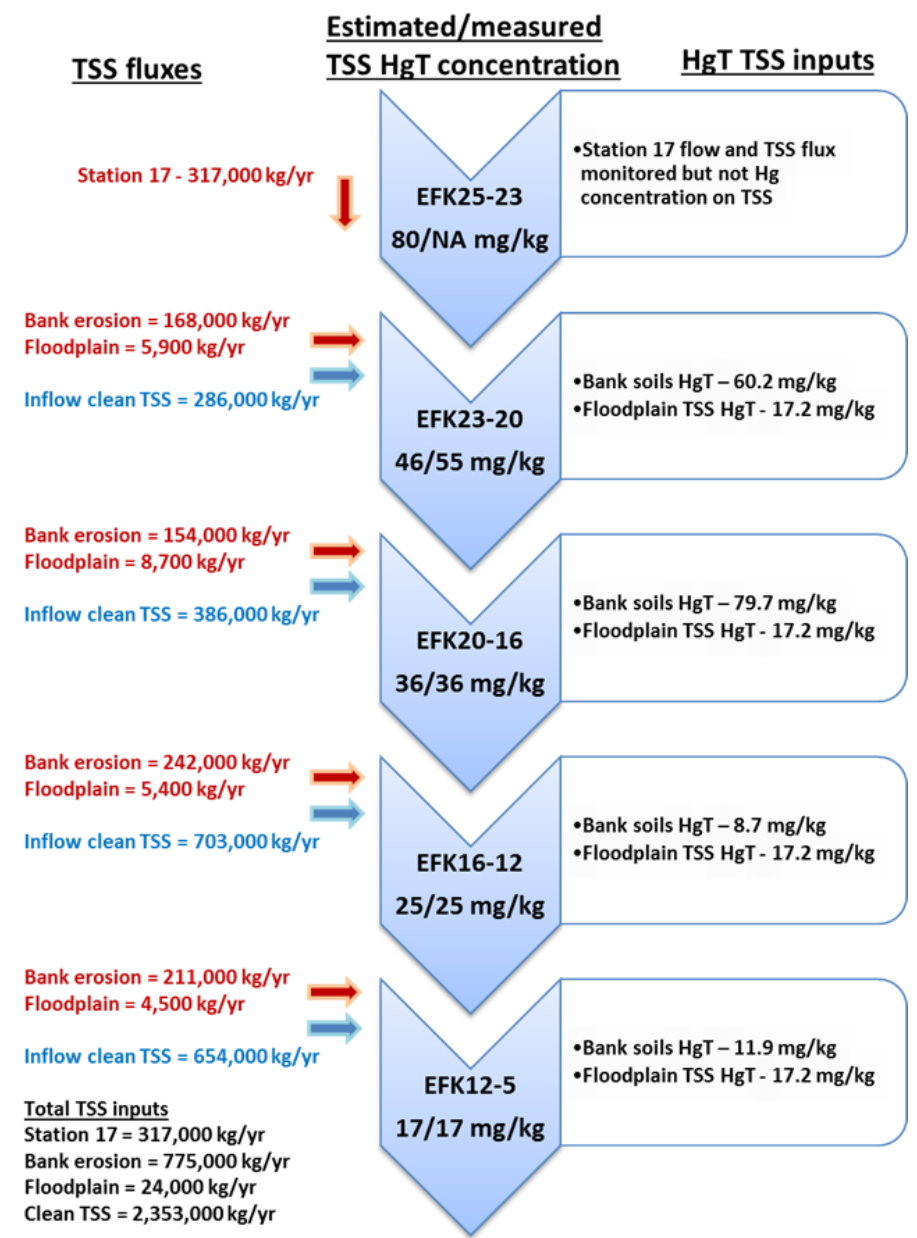

Fig. 55. Estimated total suspended solids (TSS) fluxes and associated total mercury (HgT) concentrations.(Note: EFK = East Fork Poplar Creek kilometer.) 


\subsubsection{Estimates of $\mathrm{HgT}$ and $\mathrm{MeHg}$ in periphyton}

The mechanisms for $\mathrm{HgT}$ and $\mathrm{MeHg}$ accumulation in periphyton and other materials at the base of the food chain and changes that are likely to result from environmental management activities are not well understood. Therefore, estimations of the $\mathrm{HgT}$ and $\mathrm{MeHg}$ concentrations in periphyton that are inputs to the bioaccumulation and fish uptake model have a high degree of uncertainty. Biofilm sampling by Southworth et al. (2010) and recent sampling conducted as part of the mercury SFA and mercury TD projects are providing a better, but still not complete, understanding of the concentration of $\mathrm{HgT}$ and $\mathrm{MeHg}$ in periphyton. There is a high degree of variability in the periphyton data but, similar to what is observed in aqueous samples, the concentrations of $\mathrm{MeHg}$ generally increase in the downstream direction, whereas $\mathrm{HgT}$ decreases. MeHg concentrations near Station 17 are typically in the $5 \mathrm{ng} / \mathrm{g}$ range, whereas farther downstream they can be $>20 \mathrm{ng} / \mathrm{g}$. In the model, a calibration factor was applied to the predicted $\mathrm{MeHg}$ aqueous concentration to estimate the $\mathrm{MeHg}$ concentration in periphyton on a monthly basis. Based on the available data, $\mathrm{HgT}$ concentrations in periphyton were assumed to range from $\sim 20 \mathrm{mg} / \mathrm{kg}$ in model reach EFK 23-20 to $\sim 4.5 \mathrm{mg} / \mathrm{kg}$ near EFK 5.4. For the model, the concentration of $\mathrm{HgT}$ in periphyton was assumed to be related to the estimated $\mathrm{HgT}$ concentration on TSS and to be relatively constant on a monthly basis (i.e., not change seasonally). A calibration factor was applied to the TSS HgT concentration data to estimate the $\mathrm{HgT}$ concentration in periphyton for each stream reach.

\subsubsection{Mercury Concentrations in Fish Tissue}

BMAP bioaccumulation and fish community data were used to inform and parameterize the bioaccumulation model. Past research performed by ORNL researchers has shown a significant disconnect between the amount of total mercury in either sediment or water and the resulting concentrations in aquatic biota, particularly fish. A compilation of 20 years of data reveals that various efforts to reduce total mercury concentrations in water in LEFPC have resulted in a significant reduction but little to no corresponding decrease in fish tissue concentrations (Fig. 56).

Southworth et al. (2012) reported that as concentrations of dissolved inorganic mercury (the presumed precursor for methylmercury formation) decrease steadily with distance downstream from the Y-12 Complex, waterborne methylmercury concentrations exhibit a steady increase. Similarly, concentrations of mercury in omnivorous and piscivorous fish, such as rock bass (Ambloplites rupestris), also increase in a downstream direction (Fig. 57). Understanding this paradox is one of the key elements in effectively managing EFPC such that fish concentrations fall below EPA action levels.

The mercury content in fish and other organisms is primarily $\mathrm{MeHg}$, which is produced from inorganic mercury mainly in biologically active areas of the stream bottom sediment and the periphyton that grows on bottom surfaces. The transfer of $\mathrm{MeHg}$ directly from water into fish is small compared with what is transferred through the food chain, so that pathway is not included in this iteration of the model. MeHg in the periphyton matrix (a combination of algae, detritus, sediment, and bacteria) is transferred to primary consumers or "grazers" (e.g., various species of minnows) that ingest periphyton and detritus as a primary food source (Fig. 58). These small fish, in turn, are consumed by larger fish, omnivores, and small and large predators. A secondary pathway is through macroinvertebrate grazers (such as larval stages of aquatic insects) that are consumed by insectivores (e.g., many sunfish species) that are in turn consumed by larger fish of different ages, depending on their respective sizes. 


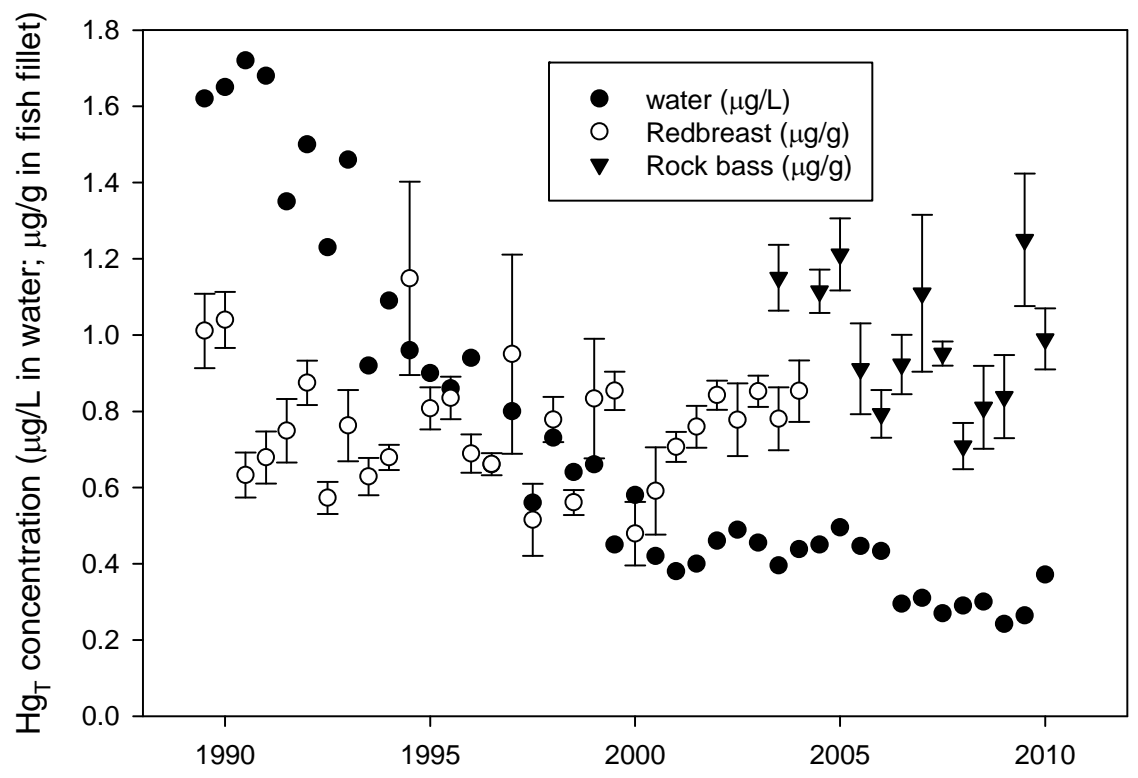

Fig. 56. Time series of total mercury (HgT) concentrations in water and fish (rock bass and redbreast sunfish) in lower East Fork Poplar Creek from 1989 to 2010.

\section{Rock Bass}

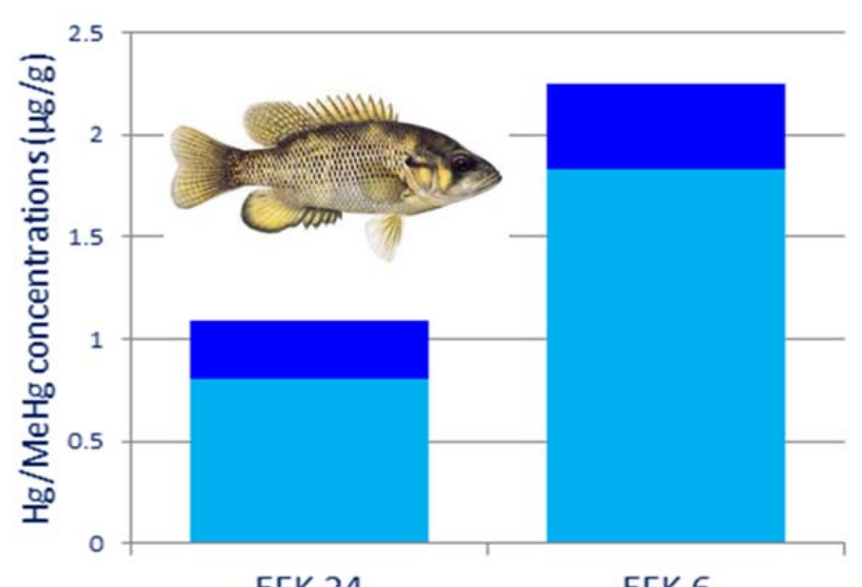

EFK 24

EFK 6

Fig. 57. Concentrations of methylmercury (MeHg; light blue) and inorganic mercury (Hg; dark blue) in rock bass at two locations (upstream at East Fork Poplar Creek kilometer [EFK] 24 and downstream at EFK 6) in lower East Fork Poplar Creek. 


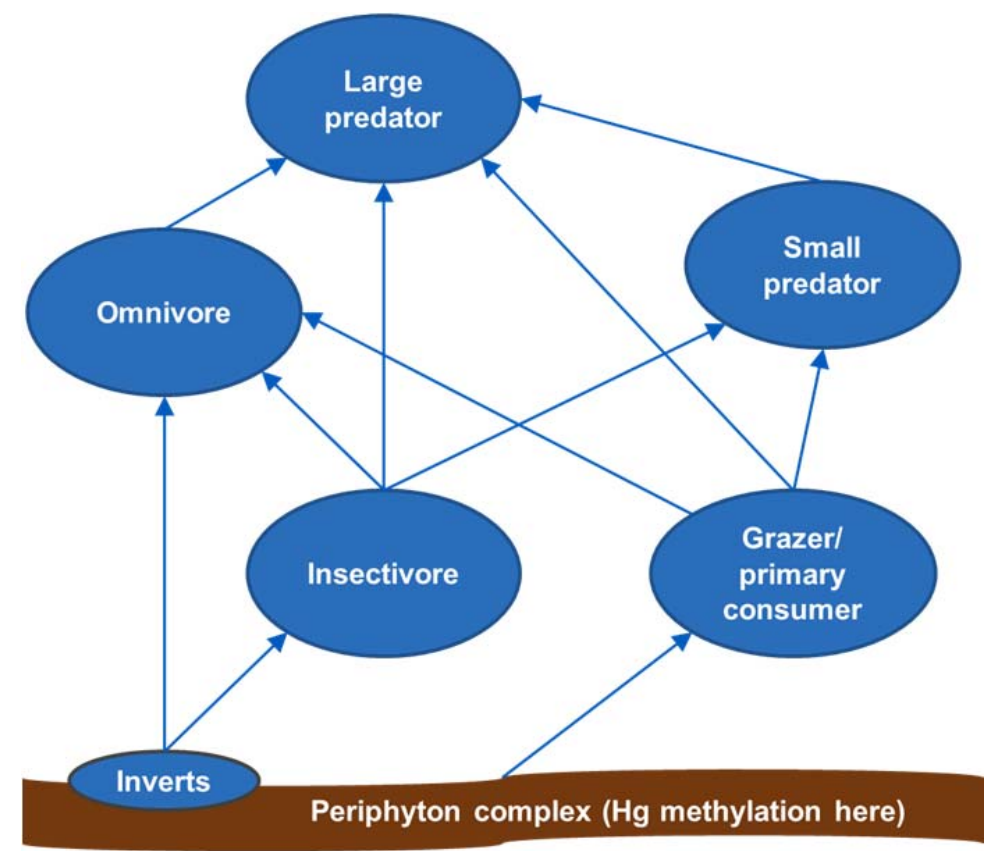

Fig. 58. Diagram of the basic food web in lower East Fork Poplar Creek showing the pathways for bioaccumulation of mercury $(\mathrm{Hg})$ from the periphyton matrix to the top predator.

The general operation of the model tracks the feeding, growth, and mercury assimilation in representative individual fish (one for each species) through their typical life span (up to 6 years). The amount of food and, therefore, mercury that is consumed and assimilated during the simulated period varies as a function of fish size, water temperature, and diet.

\section{Species}

Bioaccumulation was simulated at the same time for three species (central stoneroller minnow [Campostoma anomalum], redbreast sunfish [Lepomis auritus], and rock bass), which were representative of the three most important trophic levels in the food web (grazers, insectivores, and piscivores).

Stoneroller minnows (henceforth referred to as minnows) are the most abundant grazer in the stream and the most abundant species overall. They are of the minnow family and generally live to only 2-3 years of age. Redbreast sunfish (henceforth referred to as sunfish) are the second most abundant sunfish species in the stream and can be opportunistic feeders but generally consume aquatic and terrestrial insects. Rock bass are the most abundant large predator in the system and, depending on their age (i.e., size), can eat any age of minnow and age 1-3 sunfish. In LEFPC the comparative size of these three species is rock bass $>$ sunfish $>$ minnow. These species have similar geographic ranges and thermal physiology (i.e., the effect of temperature on feeding rate and conversion efficiency), and identical temperature multipliers were used to adjust species-specific baseline feeding rates and conversion efficiencies. Results are presented here for all three species. However, because rock bass are at the top of the food chain and have the highest concentrations of mercury in their tissue (and creek fish consumption limits will not be able to change until all species reach the regulatory target), there is an emphasis on the modeled mercury results in rock bass.

\section{Temporal Scale}

The model operates on a daily time step and runs for several years until the end of the age range that corresponds to the ages of fish collected in the past for bioaccumulation analysis (i.e., 4-6 years for rock bass and sunfish and 2-3 years for minnows). For all species, model simulations start after nearly 2 years 
of growth on January 1; these species hatch in the spring. For ease of model calculations, each year lasted 360 days ( 12 months $\times 30 \mathrm{~d}$ per month).

\section{Spatial Scale}

The $16.5 \mathrm{~km}$ stretch of LEFPC between EFKs 23.5 and 5 was divided into four bioaccumulation model reaches (Table 23) of slightly different lengths to better maintain similarity of stream type within each reach and to ensure that each reach is represented by a long-standing fish collection site (Fig. 6). The base model structure for mercury accumulation within each reach is identical except for input parameters that capture differences in mercury transport through the system (i.e., from the watershed model). Food web differences among reaches also were captured in some of the model simulations.

$\begin{aligned} & \text { Table 23. The four Structural Thinking Experiential Learning Laboratory } \\
& \text { with Animation (STELLA) bioaccumulation modeling reaches of lower East } \\
& \text { Fork Poplar Creek designated by stream kilometer and each reach's } \\
& \text { corresponding historical fish sampling locations for mercury bioaccumulation }\end{aligned}$
\begin{tabular}{cccc} 
Model reach & Stream kilometer & Distance (km) & $\begin{array}{c}\text { Fish sampling } \\
\text { location }\end{array}$ \\
\hline 1 & EFK 23.5 to 20 & 3.5 & EFKs 22, 23.4 \\
2 & EFK 20 to 16 & 4 & EFK 18.2 \\
3 & EFK 16 to 12 & 4 & EFKs $13.0,13.8$ \\
4 & EFK 12 to 5 & 7 & EFK 6.3 \\
\hline
\end{tabular}

Note $:$ EFK = East Fork Poplar Creek kilometer. 


\section{SIMULATING POTENTIAL CHANGES IN MERCURY FLUX}

\subsection{PHYSICAL-CHEMICAL WATERSHED MODELING}

\subsubsection{Approach}

The data sources and input parameters used to develop the watershed model were described in Chapter 3. The model is configured so that the watershed impacts of a reduction in flux in one or more of the mercury inputs can be assessed.

When compiling information from a large variety of sources and simulating mercury cycling in a complex watershed, there are many areas of uncertainty. While limited field and laboratory analyses were conducted as part of this project to address a few key data gaps, the model results presented herein include parameters and relationships for which complete understanding and quantification are still lacking. Thus model predictions should be viewed cautiously, with comparisons of the relative magnitude of differences among scenarios being more valid and relevant than absolute predictions of mercury and methylmercury concentrations. In addition, comparisons of LEFPC water, soil, or biota concentrations relative to regulatory criteria, whether the data are empirically derived or simulated, are highly dependent on how mercury media results are averaged. Thus care should be taken when comparing the results of model scenarios to regulatory limits; the method of mercury averaging for the model and for regulatory purposes may be different. For example, a grab sample collected at base flow is very different from a monthly composite or an annual averaging of mercury results that includes storm sampling. Similarly, there can be large variability in fish mercury concentrations, depending on fish species, age, or size class averaging used in the analysis.

The physical-chemical watershed model was designed to interact with a bioaccumulation model that predicts $\mathrm{MeHg}$ uptake into fish. Output from the watershed model can be input automatically into the bioaccumulation model to better understand how physical processes and potential source reduction measures might affect the accumulation of $\mathrm{MeHg}$ in fish. Table 24 lists model runs that were conducted to show the impact of changing various mercury input fluxes that could be representative of hypothetical source reductions on $\mathrm{HgT}$ and $\mathrm{MeHg}$ concentrations and fluxes for the watershed and within individual stream reaches. The threshold concentration for $\mathrm{HgT}$ used for reducing the periphyton $\mathrm{MeHg}$ production rates was set to $200 \mathrm{ng} / \mathrm{L}$ for these simulations. 
Table 24. Description of select model runs with different input fluxes representing different source reduction scenarios

\begin{tabular}{|c|c|c|}
\hline Scenario-flux removed & Figure \# & Results \\
\hline $\begin{array}{l}\text { 1. No management action- } \\
\text { all fluxes active }\end{array}$ & 64 & $\begin{array}{l}\text { Matches current seasonal and longitudinal stream } \\
\text { concentration trends fairly well }\end{array}$ \\
\hline 2. No floodplain flux & 65 & No impact; virtually no difference from Scenario 1 \\
\hline 3. No Station 17 flux & 66 & $\begin{array}{l}\text { Results in an expected reduction in } \mathrm{HgT} \text { concentration, } \\
\text { especially in low flow summer months, but has very little } \\
\text { impact on MeHg production in downstream reaches }\end{array}$ \\
\hline 4. No bank erosion flux & 67 & $\begin{array}{l}\text { Concentration of } \mathrm{HgT} \text { at EFK } 5.4 \text { is half that of Scenario } 3 \\
\text { but has little impact on MeHg production }\end{array}$ \\
\hline $\begin{array}{l}\text { 5. No Station } 17 \text { flux or } \\
\text { bank erosion flux from } \\
\text { EFK 23-20 and 20-16 }\end{array}$ & 68 & $\begin{array}{l}\text { Significant reduction in concentration of } \mathrm{HgT} \text { and } \mathrm{MeHg} \text { a } \\
\text { all stations }\end{array}$ \\
\hline $\begin{array}{l}\text { 6. No Station } 17 \text { flux or } \\
\text { bank erosion flux }\end{array}$ & 69 & $\begin{array}{l}\text { Slight reduction in } \mathrm{HgT} \text { concentration and somewhat } \\
\text { greater reduction in concentration in } \mathrm{MeHg} \text { than that of } \\
\text { Scenario } 5\end{array}$ \\
\hline
\end{tabular}

Note: $\mathrm{HgT}=$ total mercury; $\mathrm{MeHg}=$ methylmercury; EFK = East Fork Poplar Creek kilometer.

\subsubsection{Results}

The modeling inputs and components described in Chapters 3 and 4 (Fig. 32) were combined to predict HgT and MeHgT flux and concentration on a monthly basis at Station 17, EFK 5.4, and the other three stream reaches. Figure 59 shows the magnitude of the primary HgT inputs to the LEFPC watershed, and Fig. 60 shows the distribution of the HgT input for each stream reach for Scenario 1 (no management action). The HgT flux from bank erosion is by far the greatest input of HgT, followed by Station 17. The estimates of bank erosion based on kayak data and inclusion of elevated mercury concentrations in the HRD were reduced by a factor of 0.7 to achieve a mass balance for the estimated fluxes leaving the watershed at EFK 5.4. This reduction is well within the range of uncertainty related to the bank erosion estimates. Floodplain contributions from infiltration and runoff are relatively small compared with these other two inputs. Figure 60 shows that the majority of bank erosion flux originates from the upstream reaches EFK 23-20 and 20-16.

Figure 61 shows the magnitude of the primary MeHgT inputs to the LEFPC watershed, and Fig. 62 shows the distribution of $\mathrm{MeHg}$ inputs for the stream reaches for Scenario 1. Instream methylation is a primary source of MeHg in the creek, with lesser amounts from bank erosion and Station 17. The inputs did not add up to the flux predicted to be exiting at EFK 5.4. The difference is related primarily to stormflow particulate transport of $\mathrm{MeHgP}$. The source of this extra $\mathrm{MeHg}$ is not known, but it is estimated that the methylation rate would have to be $\sim 2.5$ times higher than what was estimated in Table 21 using the base flow $\mathrm{MeHg}$ aqueous data. The extra $\mathrm{MeHg}$ production could be related to many factors including undefined $\mathrm{MeHg}$ production mechanisms (e.g., flow and methylation in undefined hyporheic zones), cyclical scouring and washing away of periphyton during storm events with regrowth of periphyton after the storm and potential transference of the $\mathrm{MeHg}$ in periphyton to sediment and the water column through biological activity up the food chain. This is an area in which the model needs to be improved. Although the flux estimates may be low, the predictions of MeHgT concentrations from the model still should be representative of what the periphyton typically are going to be exposed to and in equilibrium with and what typically is in the creek water column. Therefore, it was determined that the predictions of $\mathrm{MeHg}$ in the water column are still useful for predicting MeHgT concentrations in periphyton in the model simulations. 




Fig. 59. Magnitude of the primary total mercury (HgT) inputs to the lower East Fork Poplar Creek watershed under the no-management-action scenario.(Note: EFK = East Fork Poplar Creek kilometer.)

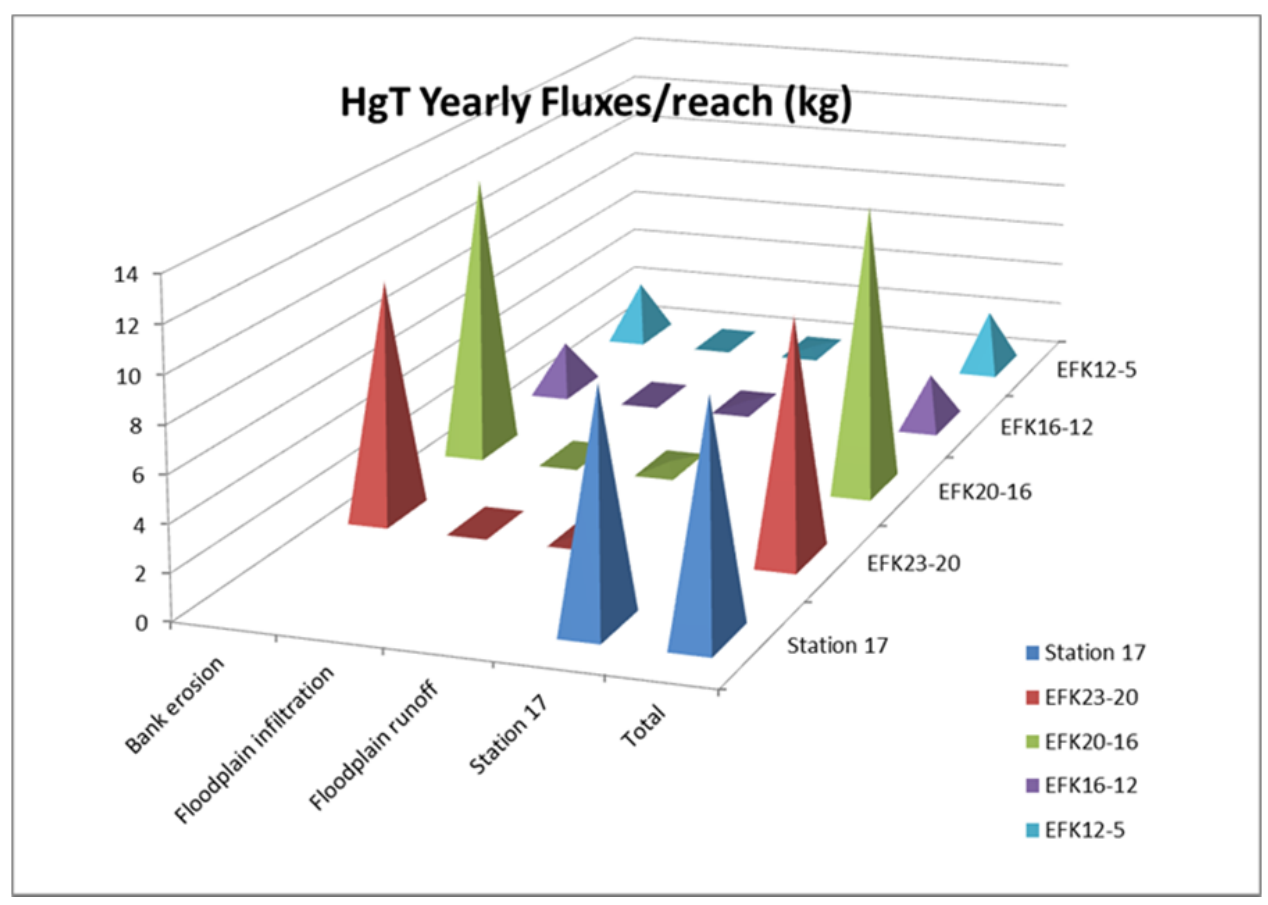

Fig. 60. Distribution of the total mercury (HgT) input for each stream reach in lower East Fork Poplar Creek under the no-management-action scenario. (Note: EFK = East Fork Poplar Creek kilometer.) 


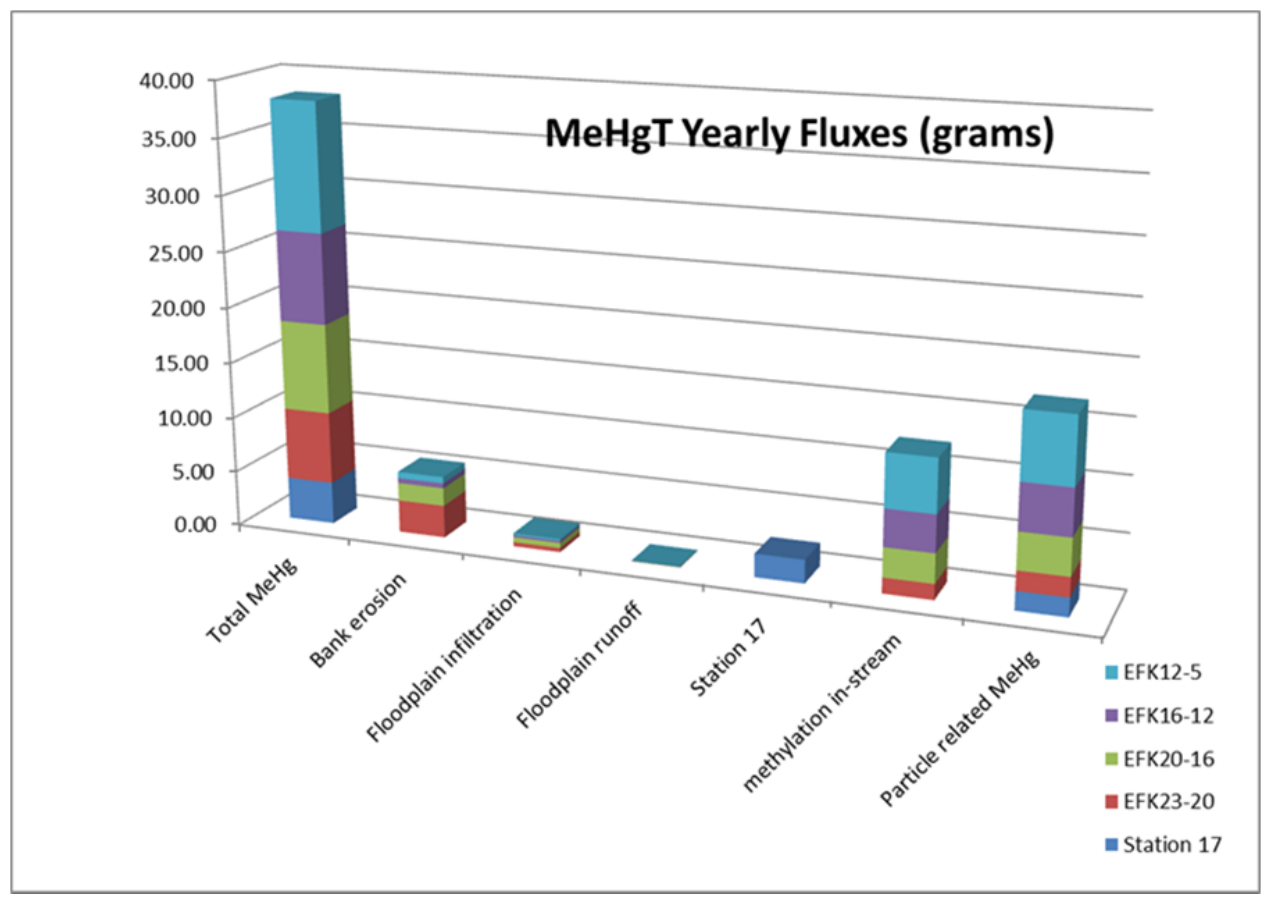

Fig. 61. Magnitude of the primary total methylmercury (MeHgT) inputs to the lower East Fork Poplar Creek watershed under the no-management-action scenario. (Note: EFK = East Fork Poplar Creek kilometer.)

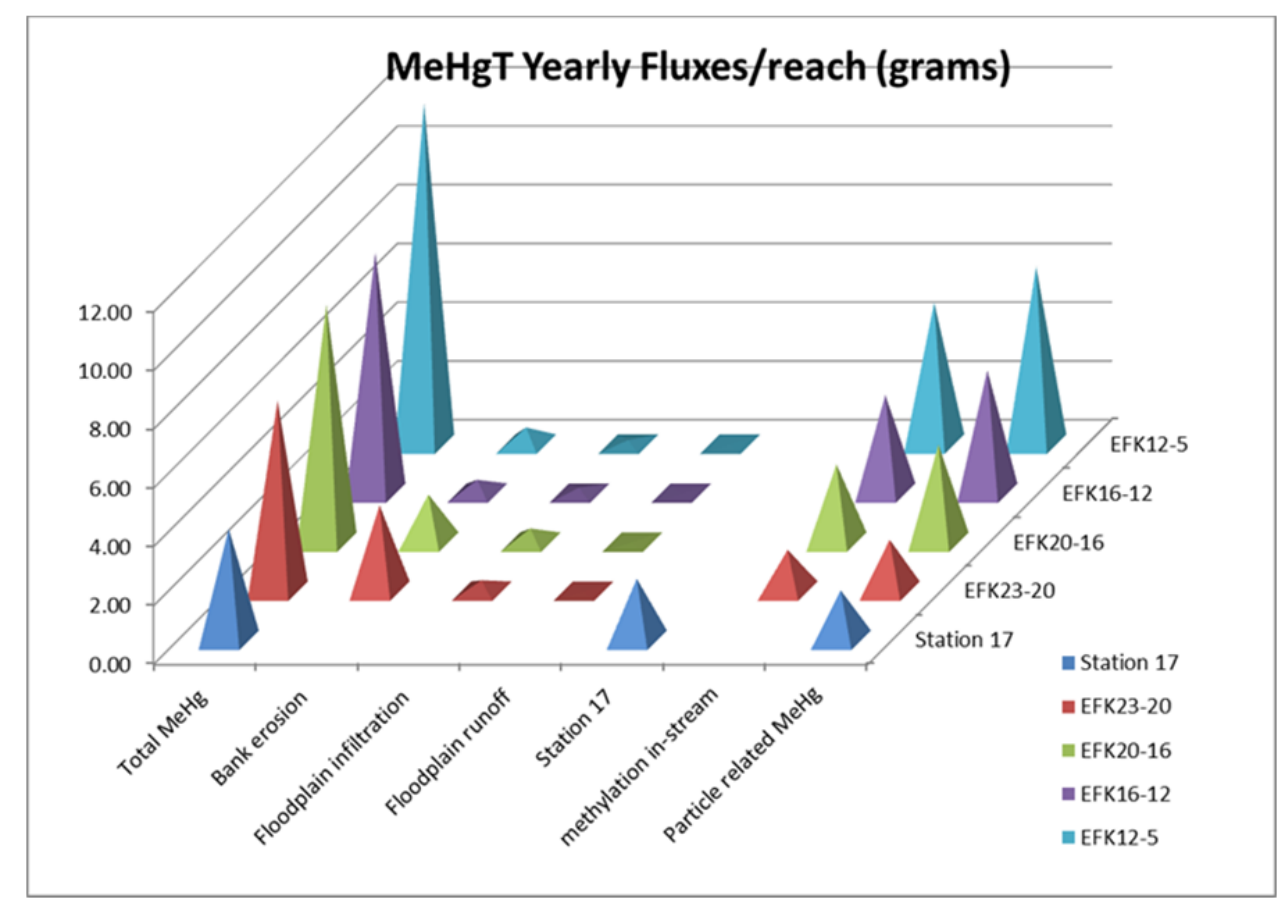

Fig. 62. Distribution of the total methylmercury (MeHgT) input for each stream reach in lower East Fork Poplar Creek under the no-management-action scenario. (Note: EFK = East Fork Poplar Creek kilometer.) 
Predicted monthly average concentrations for $\mathrm{HgT}$ for each of the five modeling reaches for each of the six source reduction scenarios are shown in Fig. 63. Additional information on the model predictions is referenced in Appendix A. Predicted monthly average concentration profiles for $\mathrm{HgT}$ and $\mathrm{MeHgT}$ for Scenario 1 (no management action) are shown in Fig. 64. The concentrations presented are representative of current average conditions (no flow augmentation). The predicted seasonal and downstream longitudinal trends shown in Fig. 64 are similar to current observations in LEFPC. Flow augmentation is not included in the model, so there likely are differences from past assessments because most of the available data are from when flow augmentation was still active. Removing flow augmentation for the simulations would tend to increase predicted concentrations, especially near Station 17, but would have no impact on the predicted total flux.

The results of eliminating the floodplain flux from leaching and overland flow in Scenario 2 (Fig. 65) are almost identical to the no-management-action scenario results. This indicates that, based on what is currently known, actions to eliminate or reduce floodplain leaching and runoff may not produce much of an impact on $\mathrm{HgT}$ or $\mathrm{MeHg}$ concentrations or fluxes unless other major sources of mercury flux are eliminated first.

Eliminating fluxes from Station 17 (Scenario 3, Fig. 66) results in an expected reduction in HgT flux and concentration, especially in low flow summer months. However, it has very little impact on $\mathrm{MeHg}$ production in downstream reaches, with the exception of the reduction in $\mathrm{MeHg}$ concentrations at EFK 23-20.

Eliminating all bank erosion fluxes (Scenario 4, Fig. 67) results in the concentration of HgT at EFK 5.4 being half that of Scenario 3, but there was little impact on $\mathrm{MeHg}$ production in any of the reaches because the threshold concentration $(200 \mathrm{ng} / \mathrm{L})$ for reducing the periphyton production rates was not reached.

For Scenario 5 (Fig. 68), a combination of eliminating bank erosion fluxes from EFKs 23-20 and 20-16 and the flux from Station 17 results in a substantial reduction in the concentration of $\mathrm{HgT}$ within all creek reaches. Additionally, a significant reduction in $\mathrm{MeHg}$ production was predicted in all reaches because the threshold concentration $(200 \mathrm{ng} / \mathrm{L})$ for reducing the periphyton production rates was reached.

Concentrations below the $20 \mathrm{ng} / \mathrm{L}$ level, thought to be low enough to result in fish tissue levels below the $0.3 \mathrm{mg} / \mathrm{kg}$ regulatory limit (Mathews et al. 2013), were achieved in all the reaches except EFKs 16-12 and $12-5$. To get below the $20 \mathrm{ng} / \mathrm{L}$ level in all the reaches, a combination of eliminating all bank erosion fluxes and the flux from Station 17 (Scenario 6, Fig. 69) was required.

Another possible method to reduce MeHg concentrations in LEFPC could be to reduce instream methylation rates through manipulation of the stream biology and/or chemistry. Figure 70 shows the impact of reducing the methylation rate used in the model by $50 \%$ on predicted aqueous $\mathrm{MeHg}$ concentrations for Scenario 5. Although a significant reduction in the $\mathrm{MeHg}$ concentration is observed when the methylation rate is reduced, it resulted in less than a 1:1 effectiveness, probably because of the reduction in methylation rate that occurs anyway in association with the reduction in $\mathrm{HgT}$ fluxes and concentrations when source terms are reduced.

There is also uncertainty associated with the methylation threshold factor that is used in the model to regulate methylation rates. Figure 71 shows the impact of using methylation threshold factors of 100, 200, and 400 on the predicted aqueous MeHg concentrations for Scenario 5 (i.e., no Station 17 flux or bank erosion flux from EFKs 23-20 and 20-16). As shown in Fig. 71, there is a significant difference in the $\mathrm{MeHg}$ concentrations predicted for the three different methylation threshold factors used. 
\begin{tabular}{l|l|l|l|l|l|l|l|l|l|l|l|l|l|l|l|l|l} 
Jan & Feb & Mar & Apr & May & Jun & Jul & Aug & Sep & Oct & Nov & Dec & Avg. \\
\hline
\end{tabular}

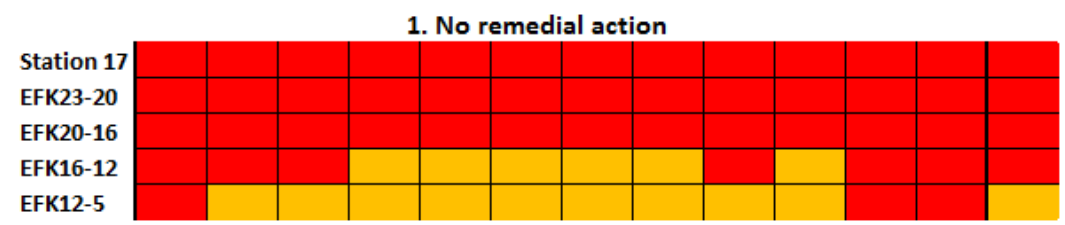

2. No Floodplain flux
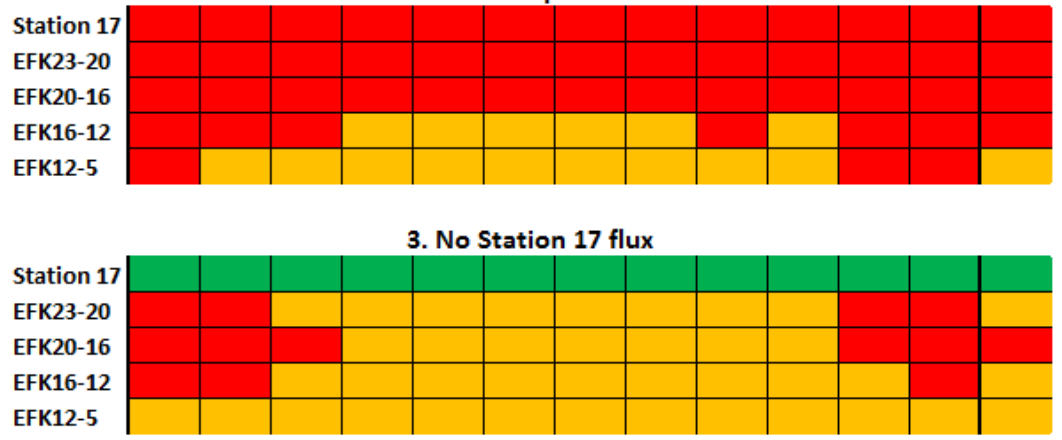

Parts per trillion

$0-50$

50-200

4. No bank erosion flux

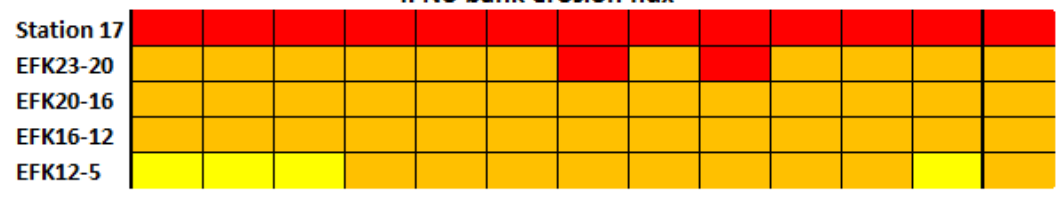

5. No Station 17 flux or bank erosion flux from EFK23-20 and EFK20-16

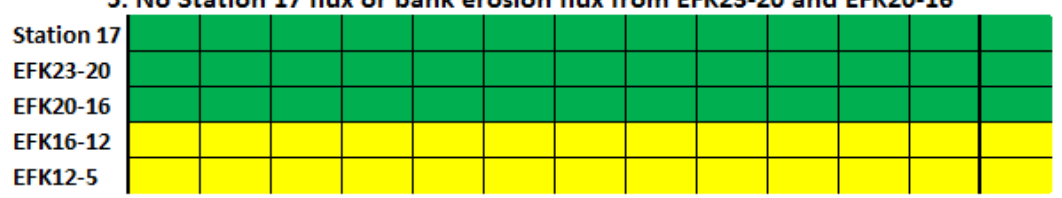

6. No Station 17 flux or bank erosion flux

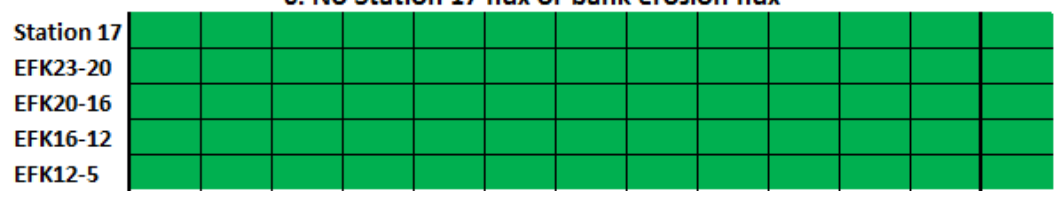

Fig. 63. Predicted approximate total mercury (HgT) concentrations for each source reduction scenario. (Note: EFK = East Fork Poplar Creek kilometer.) 

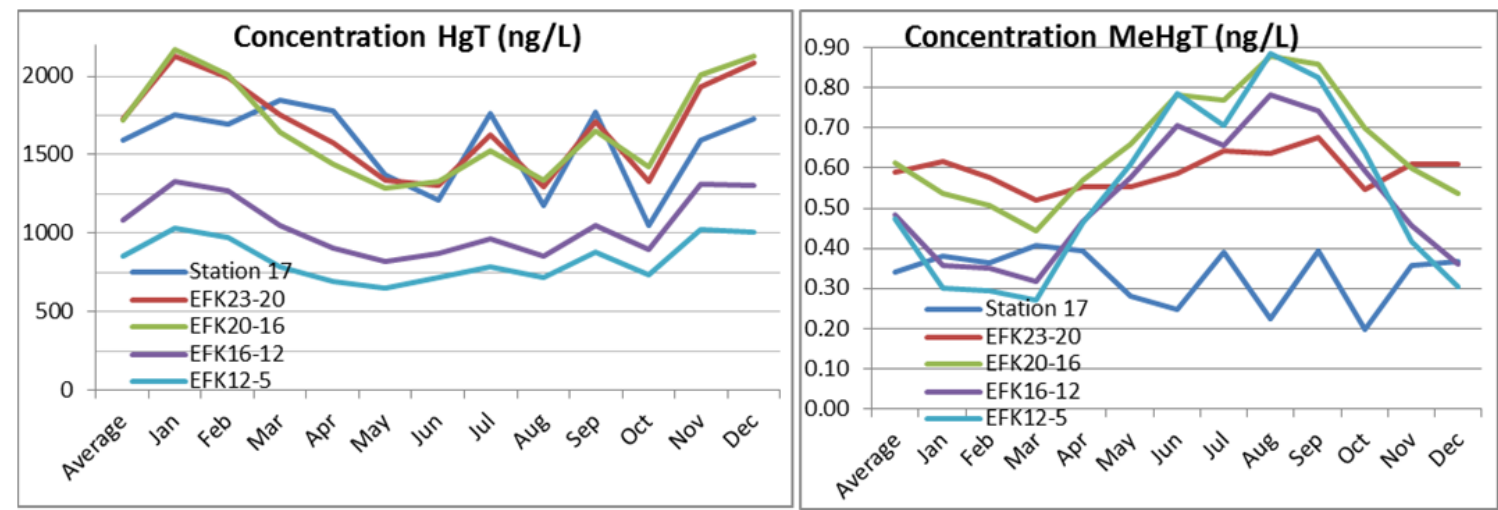

Fig. 64. Scenario 1: Simulation of total mercury (HgT) and total methylmercury (MeHgT) concentrations—no management action. (Note: EFK = East Fork Poplar Creek kilometer.)

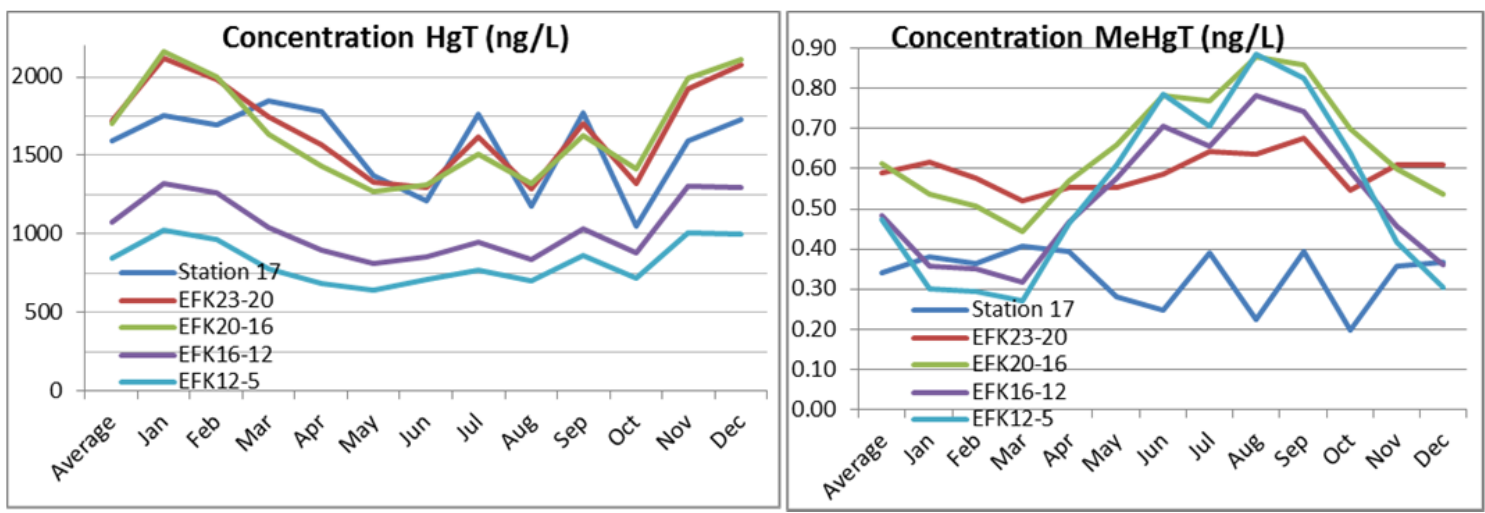

Fig. 65. Scenario 2: Simulation of total mercury (HgT) and total methylmercury (MeHgT) concentrations - no floodplain fluxes. (Note: EFK = East Fork Poplar Creek kilometer.)
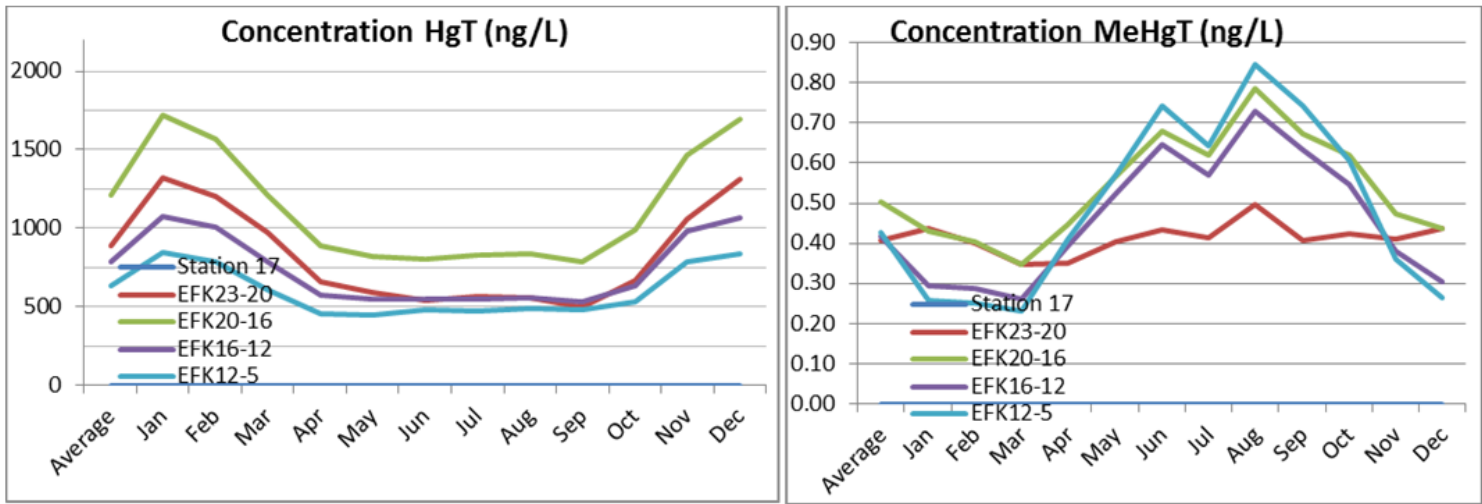

Fig. 66. Scenario 3: Simulation of total mercury (HgT) and total methylmercury (MeHgT) concentrations-no Station 17 flux.(Note: EFK = East Fork Poplar Creek kilometer.) 

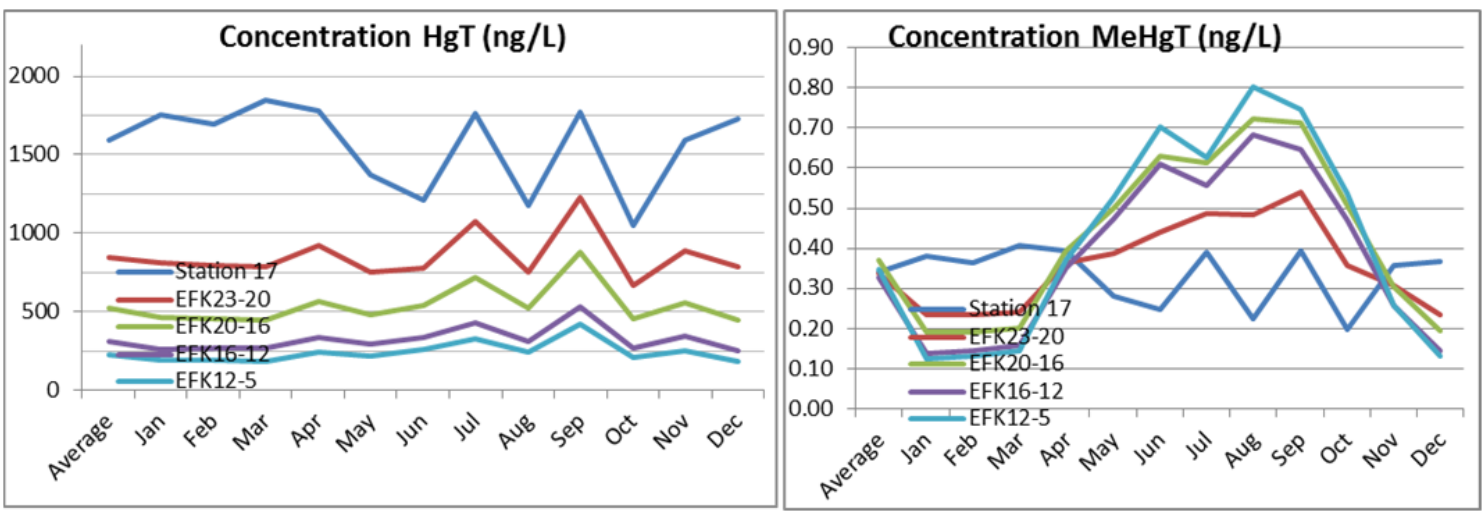

Fig. 67. Scenario 4: Simulation of total mercury (HgT) and total methylmercury (MeHgT) concentrations—no bank erosion flux.(Note: EFK = East Fork Poplar Creek kilometer.)
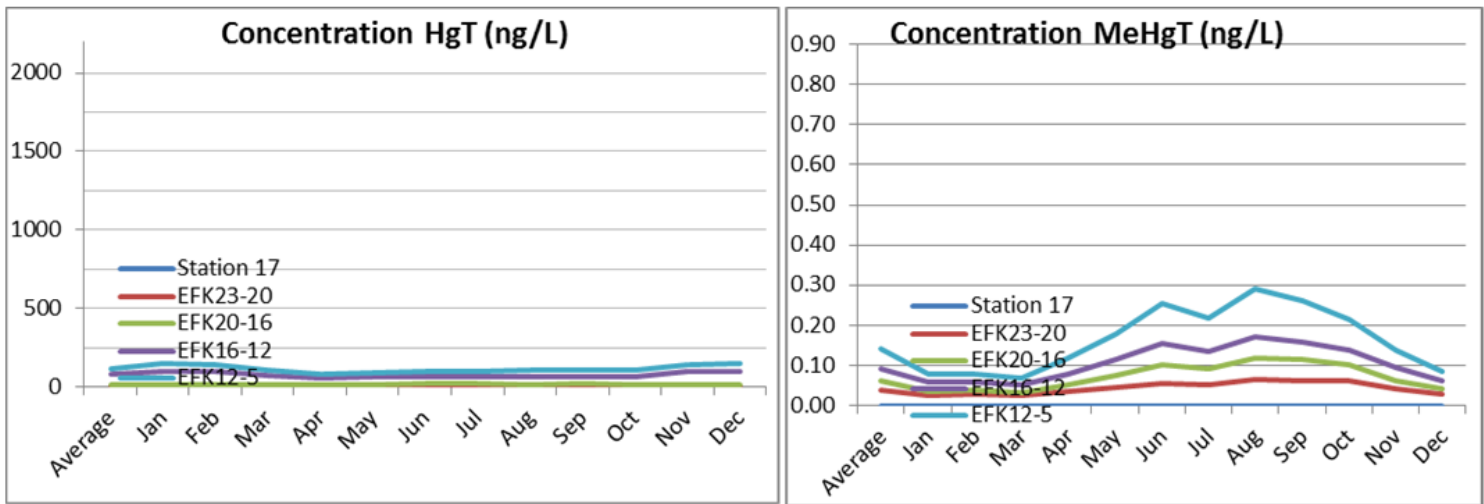

Fig. 68. Scenario 5: Simulation of total mercury (HgT) and total methylmercury (MeHgT) concentrations-no Station 17 flux or bank erosion flux from EFKs 23-20 or 20-16. (Note: $\mathrm{EFK}=$ East Fork Poplar Creek kilometer.)
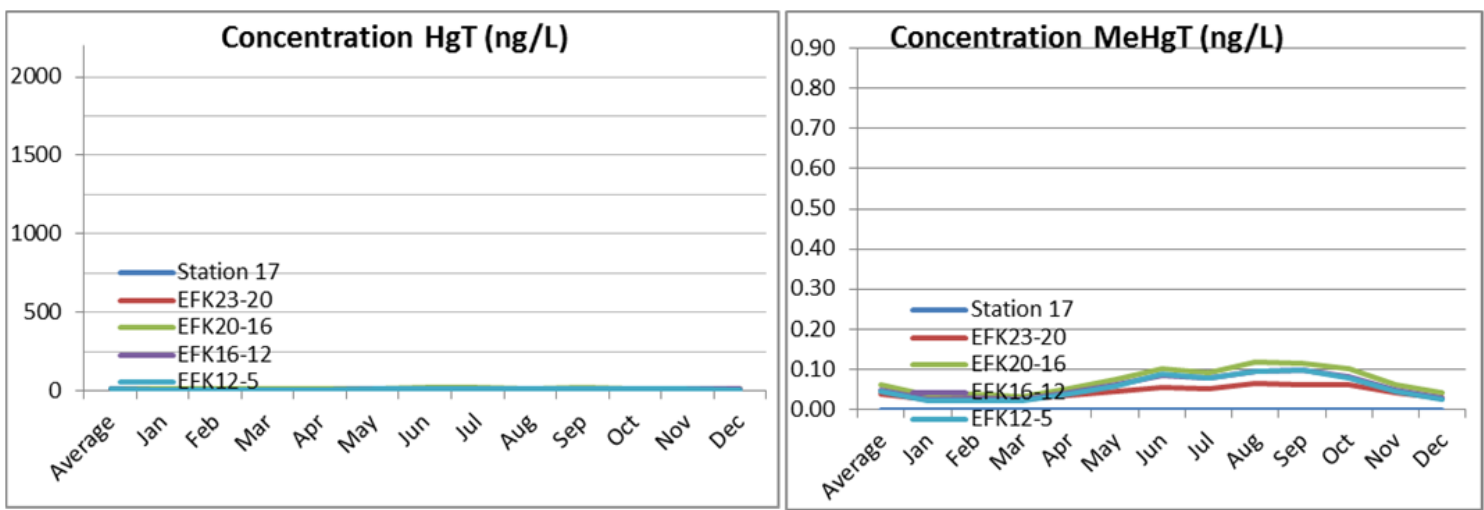

Fig. 69. Scenario 6: Simulation of total mercury (HgT) and total methylmercury (MeHgT) concentrations—no Station 17 flux or bank erosion flux.(Note: EFK = East Fork Poplar Creek kilometer.) 


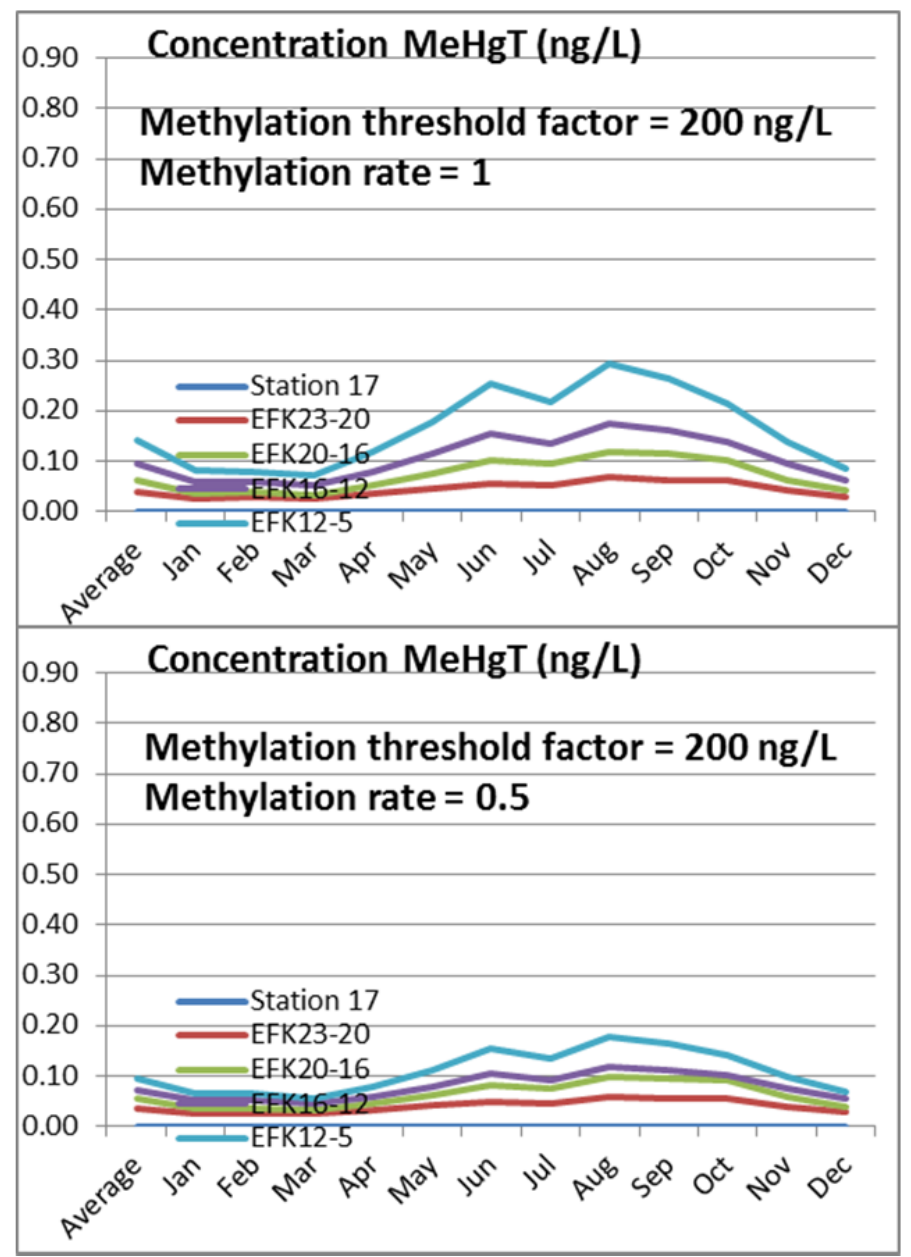

Fig. 70. Impact of reducing the methylation rate by $50 \%$ on predicted aqueous total methylmercury (MeHgT) concentrations for Scenario 5. (See Table 24; Note: EFK = East Fork Poplar Creek kilometer.) 


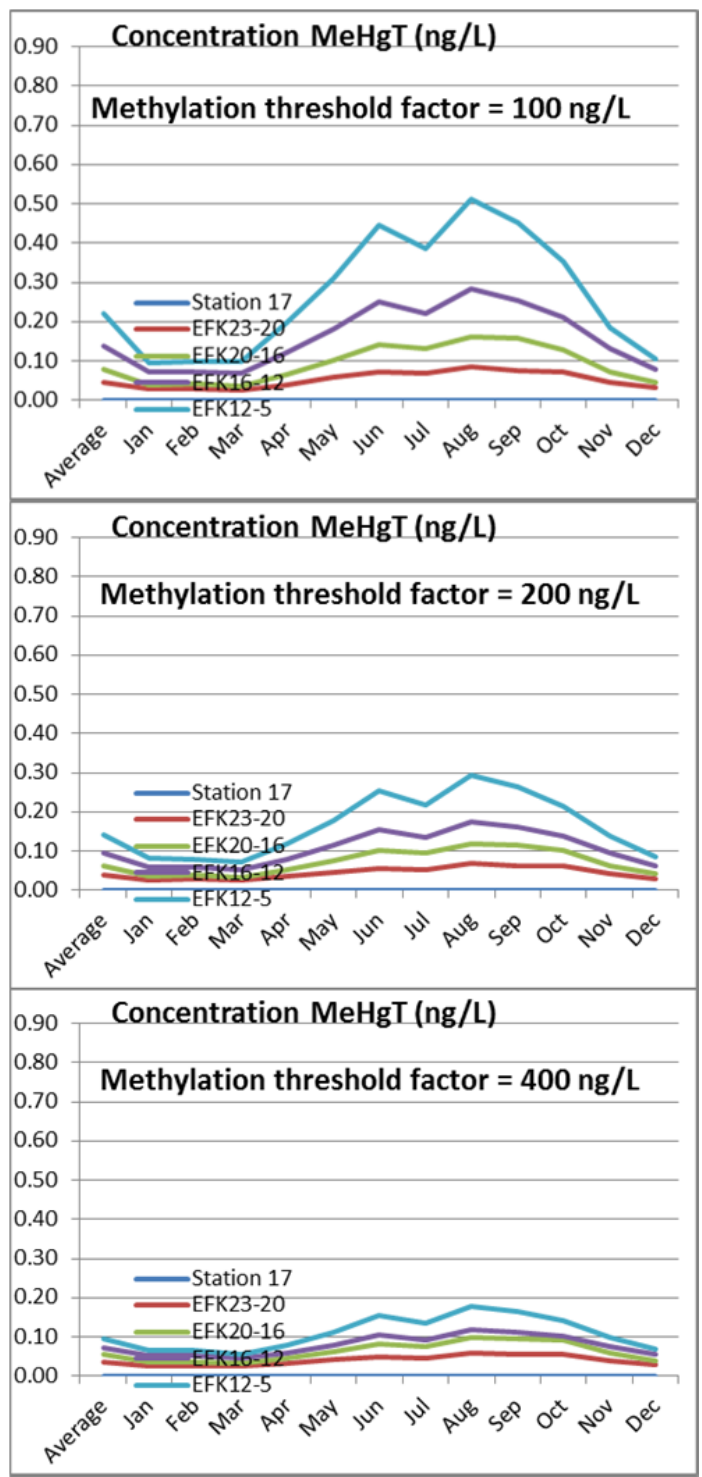

Fig. 71. Impact of methylation threshold factor on predicted aqueous total methylmercury (MeHgT) concentrations for Scenario 5 (see Table 24).

(See Table 24; Note: EFK = East Fork Poplar Creek kilometer.)

\subsubsection{Key findings}

A dynamic watershed model has been developed to assess important processes and the magnitude of different $\mathrm{HgT}$ and $\mathrm{MeHg}$ fluxes in the LEFPC watershed. The model also was used to assess potential effectiveness of environmental management actions focused on reducing these fluxes. Major findings from implementation of the model and the various simulations conducted include the following:

- The greatest flux of HgT in LEFPC is related to stormflow transport of Hg-contaminated solids entering the creek because of bank erosion in LEFPC reaches EFK 23-20 and 20-16 during high flows and freeze-thaw cycles. These are the reaches where the high concentration of $\mathrm{HgT}$ in HRDs is known to exist.

- The second greatest flux originates from Station 17 and appears to control base flow fluxes, although this could change under future conditions as source reduction upstream of Station 17 occurs. 
- The increase in flux observed during base flow conditions in the summer probably is related to bioturbation, and the decrease in flux downstream of Station 17 during winter base flow conditions may be related to the high levels of $\mathrm{HgD}$ coming out of solution and adsorbing to sediments and other surfaces in the stream.

- Although the total mass of $\mathrm{HgT}$ in the $616,000 \mathrm{~m}^{2}$ floodplain is estimated to be $\sim 57,000 \mathrm{~kg}$, the estimated flux of $\mathrm{HgT}$ related to floodplain infiltration and runoff is just a small fraction of the estimated HgT fluxes from Station 17 and bank erosion.

- The observed increase in $\mathrm{MeHg}$ concentration and flux from upstream to downstream is related primarily to instream methylation by periphyton and other biological activity, with lesser amounts contributed from bank erosion and Station 17.

- The mass inputs of MeHg did not add up to the flux predicted to be exiting at EFK 5.4. The difference is related primarily to stormflow particulate transport of MeHgP. The source of this extra $\mathrm{MeHg}$ is not known, but it is estimated that the methylation rate would have to be $\sim 2.5$ times higher than what was estimated using the base flow $\mathrm{MeHg}$ aqueous data. The extra $\mathrm{MeHg}$ production may be related at least in part to undefined $\mathrm{MeHg}$ production mechanisms (e.g., flow and methylation in undefined hyporheic zones), cyclical scouring and washing away of periphyton during storm events with regrowth of periphyton after the storm, and potential transference of the $\mathrm{MeHg}$ in periphyton to sediment and the water column through biological activity up the food chain.

- A meaningful, substantial reduction of the HgT flux in LEFPC would require addressing the flux of $\mathrm{HgT}$ originating from bank erosion (in particular from reaches EFKs 23-20 and 20-16) and from Station 17.

- Actions to eliminate or reduce LEFPC floodplain leaching and runoff would not produce much of an impact on $\mathrm{HgT}$ or $\mathrm{MeHg}$ concentrations or fluxes unless other major sources are eliminated first.

\subsection{BIOACCUMULATION MODELING}

\subsubsection{Approach}

The approach to bioaccumulation modeling for this project includes development of a predictive model based on present conditions, future changes in those conditions, and an understanding of system-wide transformation and transport mechanisms. The specific objectives of the bioaccumulation modeling that included simulation of various mercury source reduction scenarios are

1. to build a contaminant uptake model that uses outputs from lab studies and the physical-chemical watershed model to predict concentrations in the fish and food chain,

2. to use the model to test various hypotheses that might explain the temporal and spatial variation in mercury accumulation in LEFPC fish, and

3. to use the model to explore the impact of possible future source reduction actions on $\mathrm{MeHg}$ concentrations in fish.

The STELLA software uses a systems dynamics approach and produces a series of differential equations. Key components of the model are tracked as the flow of an item into and out of a "reservoir" or "stock." In this model, the stocks that were tracked include (1) weight of individual fish in grams, (2) weight of $\mathrm{MeHg}$ in an individual fish in micrograms, and (3) weight of $\mathrm{IHg}$ in an individual fish in micrograms (included in the model but not used at this time). In Fig. 72, these three stocks are represented by rectangles with fish weight at the bottom, $\mathrm{MeHg}$ in the middle, and $\mathrm{IHg}$ at the top.

The underlying foundation of the growth model is a bioenergetics model similar to those used in fisheries science for several decades. These models typically calculate fish growth, given that food consumption 
rate and various energetic and food-processing demands (i.e., basal metabolism, excretion, and egestion) are known. This model used known growth based on age at size estimates from captured fish to estimate how much food was consumed during the life of the modeled fish. In mathematical terms, the equation was solved for food consumption instead of growth. In addition, the model was simplified by combining all the energetic costs into one compartment using a single conversion efficiency factor that defined how much of the consumed food is assimilated into fish tissue (or weight). The underlying model equation for the size of the fish on day $\mathrm{x}$ is:

$$
\text { Weight }_{(\text {time } x)}=\text { Weight }_{(\text {time x-1) }}+\text { Weight of Food Consumed } \times \text { Conversion Efficiency Rate }
$$

Food consumption rate varies among the three species and, for all three, as a function of fish size. As fish grow larger, the relative food consumption (or percent of body weight consumed per day) decreases slowly. Similarly, conversion efficiency declines as fish get larger and per-gram energetic demands increase. The effects of temperature on both food consumption and conversion efficiency are included in the model as multipliers that cause a reduction in the base line maximum rates. The linkages among fish weight and the other model parameters (i.e., food consumption, conversion efficiency, temperature, etc.) can be seen in the bottom portion of the model diagram in Fig. 72, which shows a module for an individual rock bass for one of the four reaches. The entire model includes 12 such modules (three species $\times$ four reaches) with linkages among species within a reach to capture the temporally dynamic $\mathrm{MeHg}$ concentration of prey fish that are consumed by rock bass.

With every gram of food that is consumed, $\mathrm{MeHg}$ is consumed at a concentration associated with the prey item at that time. The few studies that have been done on assimilation of $\mathrm{MeHg}$ by fish via consumed food suggest that nearly all of the $\mathrm{MeHg}$ is assimilated into tissue by the consumer, though this is still an area of uncertainty. Therefore, assimilation rates of $90-100 \%$ were included in the model; variation among the three species occurred because this parameter was used to calibrate to observed $\mathrm{MeHg}$ concentrations. The two key stocks in the model- $\mathrm{MeHg}$ content and fish weight-were used to calculate a running estimate of $\mathrm{MeHg}$ concentration ( $\mu \mathrm{g} \mathrm{MeHg} / \mathrm{g}$ fish). 


\section{ROCK BASS (F1-piscivore)}

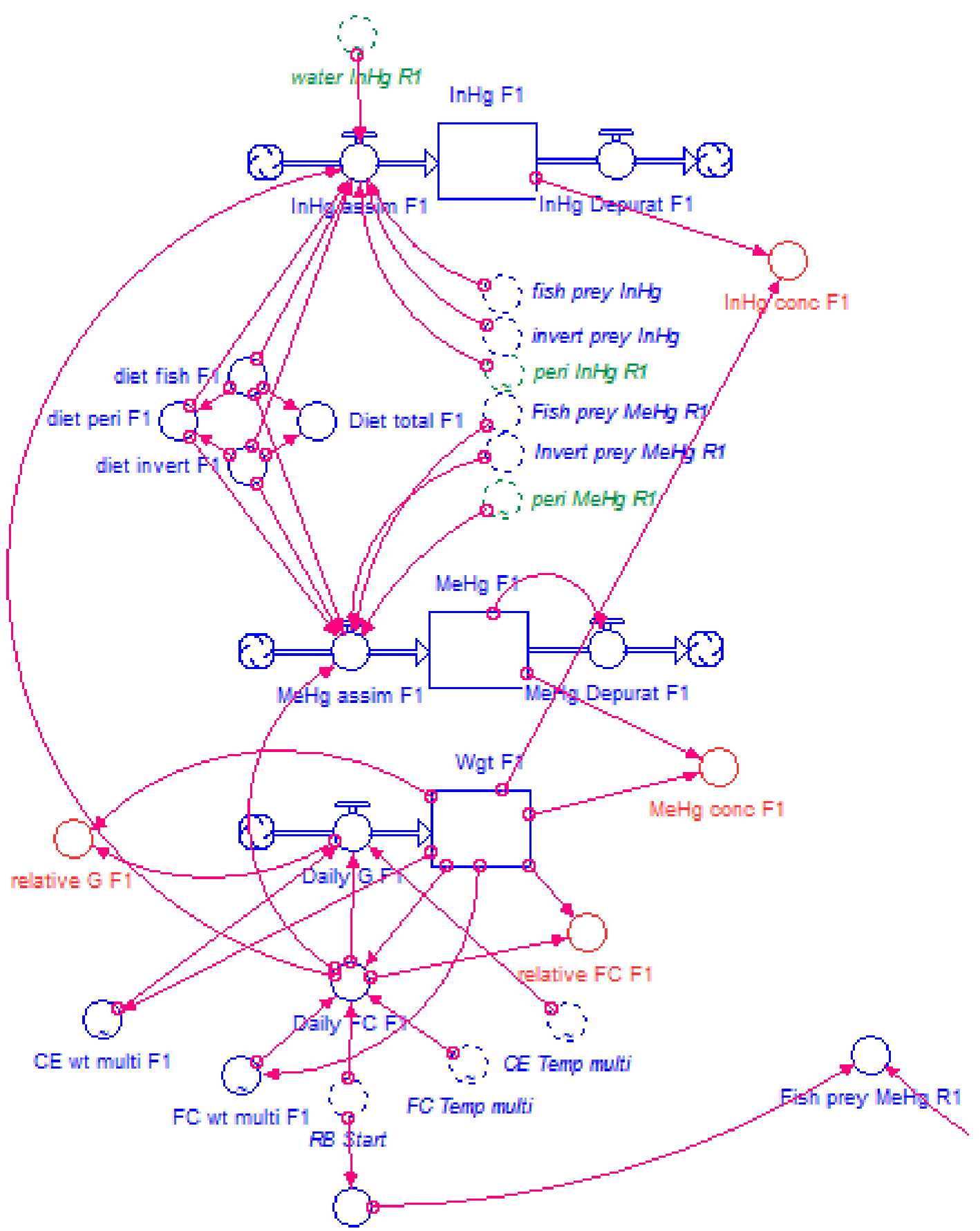

Age F1

Fig. 72. Diagram of the Structural Thinking Experiential Learning Laboratory with Animation (STELLA) model for mercury accumulation in an individual rock bass for a single reach. This module was replicated for each of four reaches and for all three species with linkages among species. (Notes: $\mathrm{CE}=; \mathrm{RB}=; \mathrm{FC}=; \mathrm{InHg}=$ inorganic mercury; $\mathrm{MeHg}=$ methylmercury.) 


\section{Diets}

The diets for the three species differed as indicated in Fig. 58. The diet of the minnow was consistent throughout its life and comprised $80 \%$ periphyton matrix and $20 \%$ invertebrates. The diet of the sunfish was consistent throughout its life and comprised $80 \%$ invertebrates and $20 \%$ periphyton matrix. The periphyton $\mathrm{MeHg}$ concentration ( $\mu \mathrm{g} / \mathrm{g}$ dry weight) was provided to the model from output of the watershed model as described in the previous sections via a direct linkage between the STELLA model and the Excel spreadsheet of the watershed model. The $\mu \mathrm{g} / \mathrm{g}$ dry weight value was converted to a wet weight value during the consumption step by dividing by a factor of 10 . These values vary monthly and among the four reaches but not from year to year in the simulations. Invertebrate concentrations of $\mathrm{MeHg}$ $(\mu \mathrm{g} / \mathrm{g}$ wet weight) are calculated directly from the mean annual periphyton concentration by multiplying by a factor of 10 . This multiplier was based on the relative concentrations of $\mathrm{MeHg}$ in periphyton and invertebrates as measured in LEFPC.

Rock bass diets consisted of invertebrates, minnows, and sunfish. The MeHg concentrations for minnows and sunfish were averaged separately for 4-month periods (January-April, May-August, and SeptemberDecember) and increased as both species aged. For the purpose of simulation, rock bass consumed minnows that were 1 year younger than they were at the time of consumption. Rock bass diets ranged from $100 \%$ fish to $70 \%$ fish $/ 30 \%$ invertebrates. The fish diets consisted of 55-100\% grazers (represented by stoneroller minnows) and the rest insectivores (represented by redbreast sunfish). These proportions varied among different simulations as described in Fig. 73.

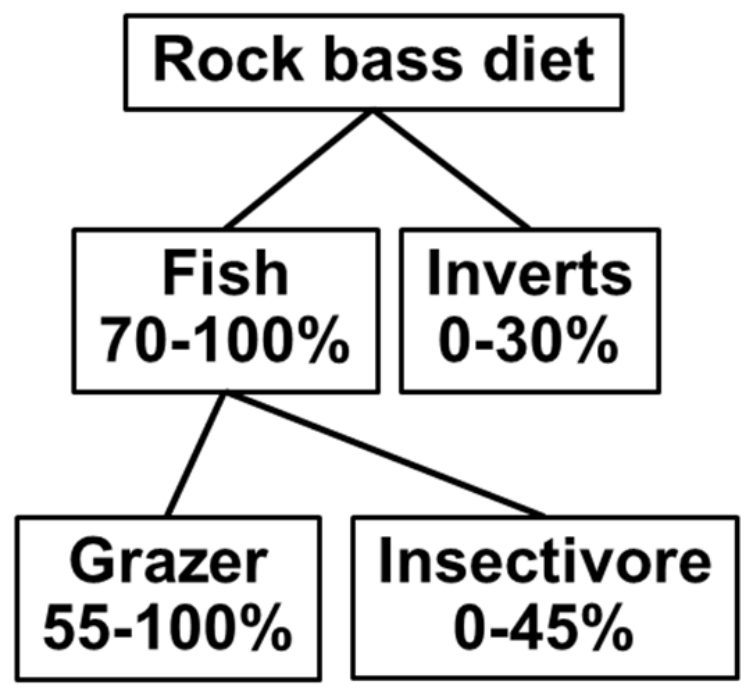

Fig. 73. Range of prey item compositions simulated for rock bass.

\section{Model Calibration}

Once the model was parameterized and tested, it was calibrated first to achieve the appropriate sized fish at age as determined based on length-weight data from fish community studies conducted throughout LEFPC and a general knowledge of size at age for these species. Calibration was accomplished with simulations in reach 2 under base conditions, with a rock bass diet of 70:30 fish:invertebrate and a fish diet mixture of 70:30 minnow:sunfish. Food consumption rate and conversion efficiency rates were adjusted from initial baseline values of $0.025 \mathrm{~g} / \mathrm{g}$ per day and $20 \%$, respectively, until reasonable size-at-age matches with observed were produced. Additional adjustments were made to the 
size-dependent multipliers for both food consumption and conversion efficiency if needed to maintain calibration throughout the life of the simulation.

A second calibration was made to match observed average body burdens of $\mathrm{MeHg}$ for the three species in LEFPC. Because of the high degree of spatial and temporal variability in body burden concentrations, the research team selected calibration targets of roughly $0.2,0.8$, and $1.4 \mathrm{mg} \mathrm{MeHg} / \mathrm{kg}$ for age 2 minnows, age 5 sunfish, and age 5 rock bass, respectively. Calibration was achieved by adjusting the assimilation efficiency for each species, with final values selected as 1.0, 1.0, and 0.9, for minnow, sunfish, and rock bass, respectively.

\section{Sensitivity Simulations}

Researchers used variations on a baseline simulation to test the sensitivity of various components of the model to help understand both the behavior of the model and the possibility that any of the varied parameters might partially explain the upstream to downstream differences in $\mathrm{MeHg}$ concentration in fish.

Age - During the collection of fish for bioaccumulation determination, ORNL field crews try to collect a relatively narrow range of sizes of any one species in hopes that the fish are generally the same age. However, during some years at some sites, this is not possible; the size range of fish, especially for sunfish and rock bass, can represent up to 3 years difference in age. Looking at the sensitivity of the model output to age did not require any change in parameters from baseline but only meant collecting interim output before reaching the end of the simulation. Comparisons were made for minnows ages 1-3 and for sunfish and rock bass ages 4-6.

Temperature - Because of the thermal dependence of many physiological processes, temperature plays a significant role in food consumption and growth and, therefore, contaminant uptake. The model includes a feature that allows for easy addition or subtraction of temperature from the baseline profile. This is useful for assessing changes in temperature resulting from flow augmentation, riparian shade enhancement, longitudinal warming, climate change, etc. Three simulations were run at the baseline thermal regime $\left(-1,+1\right.$, and $\left.+2^{\circ} \mathrm{C}\right)$ to determine the difference in rock bass $\mathrm{MeHg}$ concentrations relative to the baseline.

Diet-Because different classes of food items can vary greatly in their contaminant concentration, diet can play a large role in the rate of $\mathrm{MeHg}$ bioaccumulation in consumers. Researchers evaluated the effect of diet by varying the amount of invertebrate prey (0-30\%) and fish prey (70-100\%) in increments of 5\% and by varying the composition of fish prey in the diet between grazers $(55-100 \%)$ and insectivores $(0-$ $45 \%$ ) in increments of $10 \%$ (Fig. 73). In addition, simulations compared the outcome if rock bass consumed grazers and insectivores, based on their relative abundance as determined in the four reaches during annual sampling in 2013 (Fig. 74). The relative proportion of grazers and planktivores at each site based on community sampling was simulated by setting the percent insectivores value at $35,62,46$, and 74\% for EFK 23.4, EFK 18.7, EFK 13.8, and EFK 6.3, respectively. 


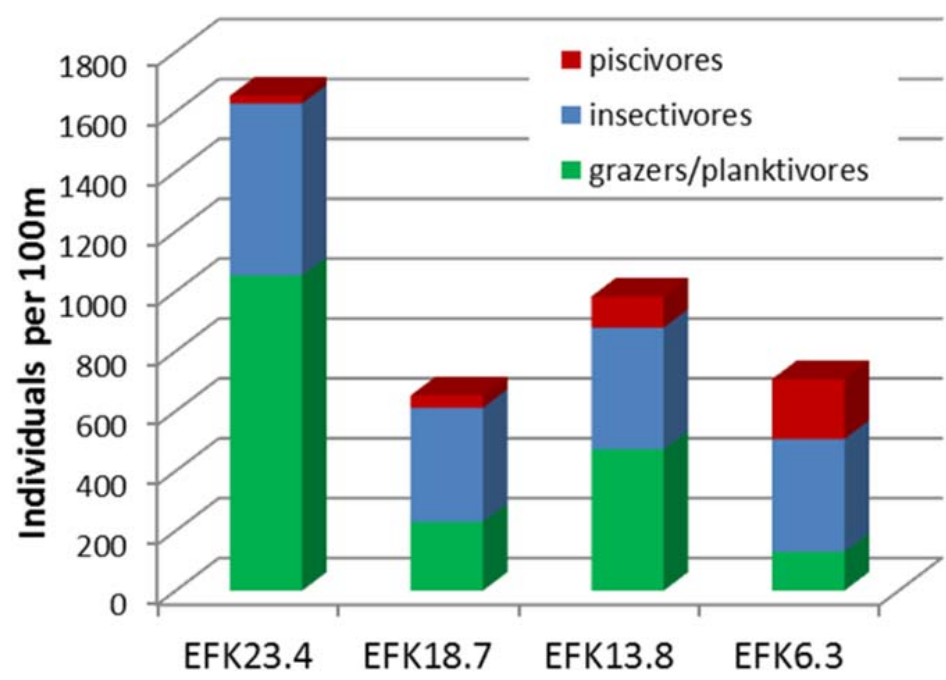

Fig. 74. Number of individuals representing three trophic levels (grazers, insectivores, and piscivores) during community sampling in spring and fall 2013 at four East Fork Poplar Creek kilometer (EFK) locations.

Simulation models like the one presented here also can provide useful information about what changes are necessary in baseline conditions to achieve a different, more desired result - in this case, lower $\mathrm{MeHg}$ concentrations in fish. Simulations were run with decreasing $\mathrm{MeHg}$ concentrations in periphyton to see how fish concentrations would respond. Simulations were run at 50,25, and $15 \%$ of the baseline values used in the other simulations.

\section{Watershed Model Linked Scenarios}

The bioaccumulation model as presented here was designed to interact with the watershed model described in Section 4.1 that predicts mercury concentrations in the water and sediment of LEFPC and into the periphyton matrix based on various stream and watershed characteristics and processes. Output from the watershed model can be input automatically into the bioaccumulation model to understand better how physical processes and potential source reduction measures might affect the accumulation of $\mathrm{MeHg}$ in fish. Output from the watershed model scenarios presented in Table 24 was imported into the bioaccumulation model to simulate the effects on $\mathrm{MeHg}$ concentrations of relevant rock bass, sunfish, and minnows.

\subsubsection{Results}

\section{Sensitivity Simulations}

Initial calibrations with baseline conditions were designed to produce $\mathrm{MeHg}$ concentrations in adult minnows, sunfish, and rock bass that were similar to those observed in recent years from fish collected from LEFPC. This calibrated baseline simulation (based on conditions in Reach 2, EFK 18.2) also provides valuable information on how important age and size are as factors in explaining some of the observed variations in bioaccumulation studies. Plots of $\mathrm{MeHg}$ concentrations for adult fish of the age used in bioaccumulation studies show a year-to-year increase of about $21 \%$ for sunfish and rock bass (Fig. 75). 


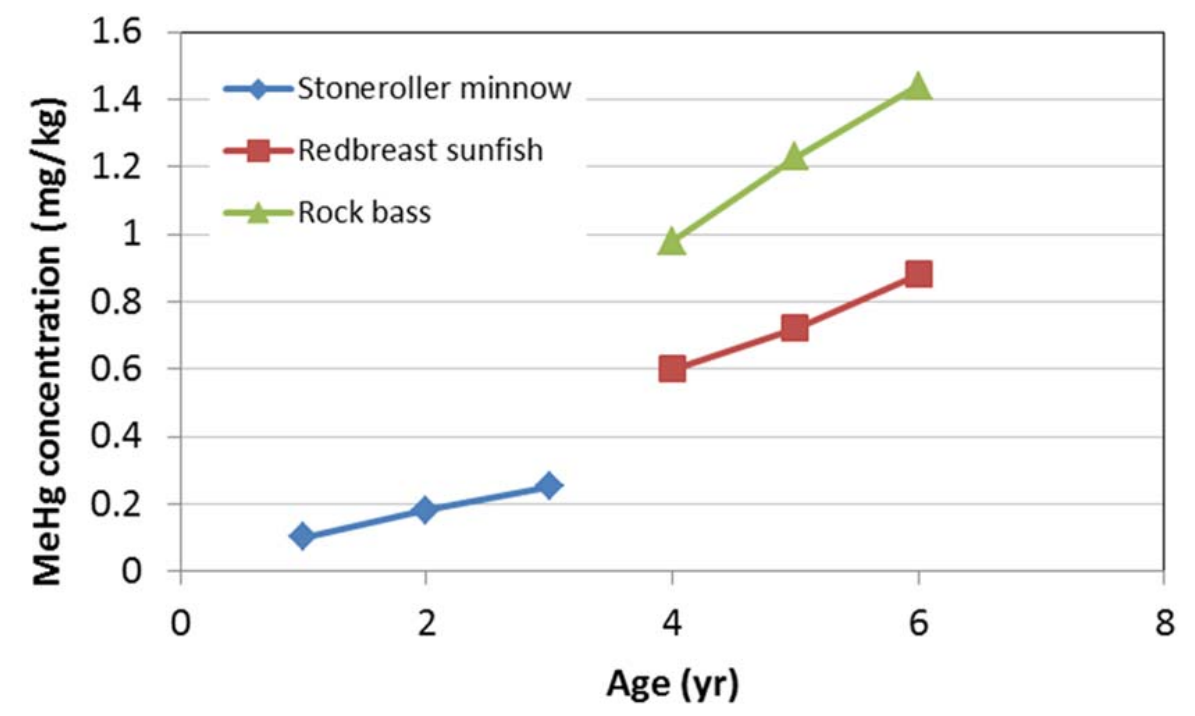

Fig. 75. Model simulated methylmercury (MeHg) concentrations in rock bass, redbreast sunfish, and stoneroller minnow at typical age of collection.

After calibration, baseline simulations were expanded to all four reaches, and a general increasing trend in $\mathrm{MeHg}$ concentrations in rock bass reflected the spatial differences in periphyton concentrations used for the observed baseline conditions (Fig. 76). The increase from EFK 23.4 to EFK 6.3 (upstream to downstream) in the baseline simulation was approximately $25 \%$.

Lowering the year-round thermal regime by $1{ }^{\circ} \mathrm{C}$ or raising it by 1 and $2{ }^{\circ} \mathrm{C}$ resulted in a change in rock bass $\mathrm{MeHg}$ concentration of about $6 \%$ per degree change at all sites (Fig. 76).

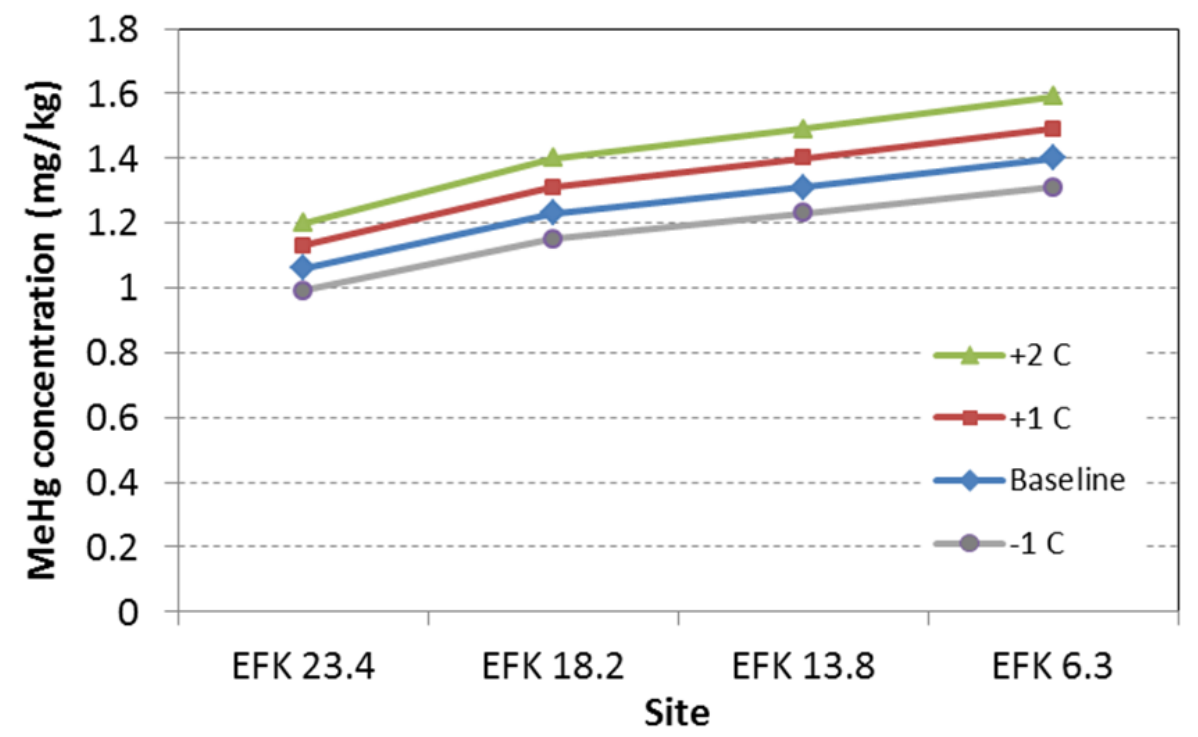

Fig. 76. Model simulated methylmercury (MeHg) concentrations in 5-year-old rock bass using the baseline temperature regime for lower East Fork Poplar Creek and the baseline $-1,+1$, and $+2^{\circ} \mathrm{C}$.

(Note: $\mathrm{EFK}=$ East Fork Poplar Creek kilometer. $)$ 
Simulating a range of diets with invertebrate:fish ratios ranging from 30:70 to 0:100 and the fish mixture ranging from 0:100 to 60:40 minnows:sunfish revealed a nearly twofold difference in $\mathrm{MeHg}$ concentrations in rock bass over the range of diet mixes (Fig. 77). High invertebrate and no-sunfish diets produced the lowest amount of bioaccumulation, and all fish diets of mostly sunfish produced the highest concentrations.

Simulations also were conducted with diets that reflected the relative distribution of prey types observed during field sampling at the four stream reaches. For three of the reaches, the proportion of insectivores (i.e., the sunfish trophic level) was higher than the value used in the baseline simulations and resulted in higher predicted MeHg concentrations in rock bass (Fig. 78).



Fig. 77. Model simulated methylmercury (MeHg) concentrations in 5-year-old rock bass at the second reach with different combinations of diets-invertebrate and fish prey items. 


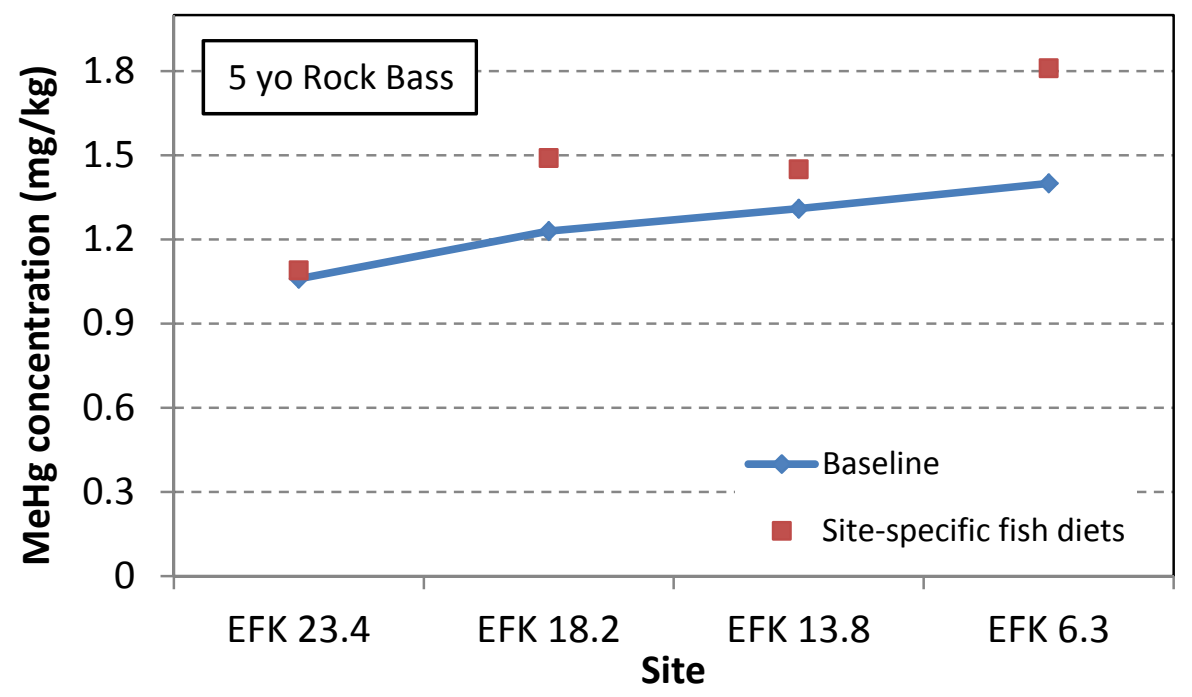

Fig. 78. Model simulated methylmercury (MeHg) concentrations in 5-year-old rock bass with a baseline diet (i.e., $30 \%$ invertebrates, $21 \%$ redbreast sunfish, and $49 \%$ stoneroller minnow) compared with site-specific sunfish:minnow proportions based on field observations of prey abundance.

(Note: EFK = East Fork Poplar Creek kilometer.)

\section{Watershed Model-Linked Scenarios}

The periphyton concentration results from the scenarios modeled with the watershed model were imported into the bioaccumulation model to determine the relative effect of each scenario on fish $\mathrm{MeHg}$ concentrations. Invertebrate prey concentrations for each of the scenarios were calculated as directly related to the periphyton concentrations (Table 25) based on concentrations determined from field collections of periphyton and various invertebrates in LEFPC.

Predicted average concentrations for $\mathrm{MeHg}$ in rock bass, sunfish, and minnows for each of the five modeling reaches are shown in Fig. 79. Additional information on the model predictions is referenced in Appendix A. Model results suggest an almost tenfold difference between the no-management-action scenario and the maximum source reduction scenarios for sunfish (including two different sizes; 3-yearold sunfish represent the age most commonly collected in EFPC), 5-year-old rock bass, and 2-year-old minnow concentrations (Fig. 80). Scenarios with no source reduction beyond present conditions produced the highest concentrations of $\mathrm{MeHg}$ in rock bass. Removing the floodplain contribution had only a minimal effect. Eliminating the source of mercury at Station 17 reduced fish concentrations by 10-20\%, and removing mercury input associated with bank erosion produced a $15-30 \%$ decrease in fish concentrations. The largest declines were associated with a combination of turning off bank erosion and eliminating inputs at Station 17.

Simulations of progressively lower periphyton $\mathrm{MeHg}$ concentrations produced lower concentrations in minnows and sunfish, which were passed on to rock bass at the top of the food web (Fig. 81). On average across the four reaches, a decrease in periphyton $\mathrm{MeHg}$ concentration to $50 \%$ of baseline resulted in an average reduction in age 5 rock bass $\mathrm{MeHg}$ concentration to $53 \%$ of baseline. Likewise, drops in periphyton $\mathrm{MeHg}$ to 25 and 15\% of baseline resulted in drops in rock bass $\mathrm{MeHg}$ to 30 and $21 \%$ of baseline concentrations, respectively. These reductions are close to, but not quite, one-to-one. 
Table 25. Methylmercury (MeHg) concentrations in invertebrates and periphyton used in bioaccumulation model during watershed linked scenarios. The periphyton values are direct output from the watershed model

\begin{tabular}{|c|c|c|c|c|c|c|c|c|}
\hline & \multicolumn{4}{|c|}{$\begin{array}{l}\text { Invertebrate prey } \\
\text { ( } \mu \text { g/g wet weight) }\end{array}$} & \multicolumn{4}{|c|}{ Periphyton ( $\mu \mathrm{g} / \mathrm{g}$ dry weight) } \\
\hline & $23-20$ & $20-16$ & $16-12$ & $12-6$ & $23-20$ & $20-16$ & 16-12 & $12-6$ \\
\hline 1. No management action & 0.149 & 0.164 & 0.133 & 0.136 & 0.015 & 0.016 & 0.013 & 0.014 \\
\hline 2. No floodplain flux & 0.140 & 0.151 & 0.124 & 0.128 & 0.014 & 0.015 & 0.012 & 0.013 \\
\hline 3. No Station 17 flux & 0.103 & 0.135 & 0.116 & 0.123 & 0.010 & 0.014 & 0.012 & 0.012 \\
\hline 4. No bank erosion flux & 0.090 & 0.108 & 0.097 & 0.106 & 0.009 & 0.011 & 0.010 & 0.011 \\
\hline $\begin{array}{l}\text { 5. No Station } 17 \text { flux or bank } \\
\text { erosion flux from EFK } 23-20 \\
\text { and EFK } 20-16\end{array}$ & 0.011 & 0.018 & 0.027 & 0.042 & 0.001 & 0.002 & 0.003 & 0.004 \\
\hline $\begin{array}{l}\text { 6. No Station } 17 \text { flux or bank } \\
\text { erosion flux }\end{array}$ & 0.011 & 0.018 & 0.015 & 0.014 & 0.001 & 0.002 & 0.001 & 0.001 \\
\hline
\end{tabular}

Note: $\mathrm{EFK}=$ East Fork Poplar Creek kilometer. 


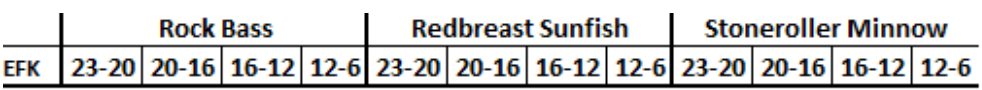
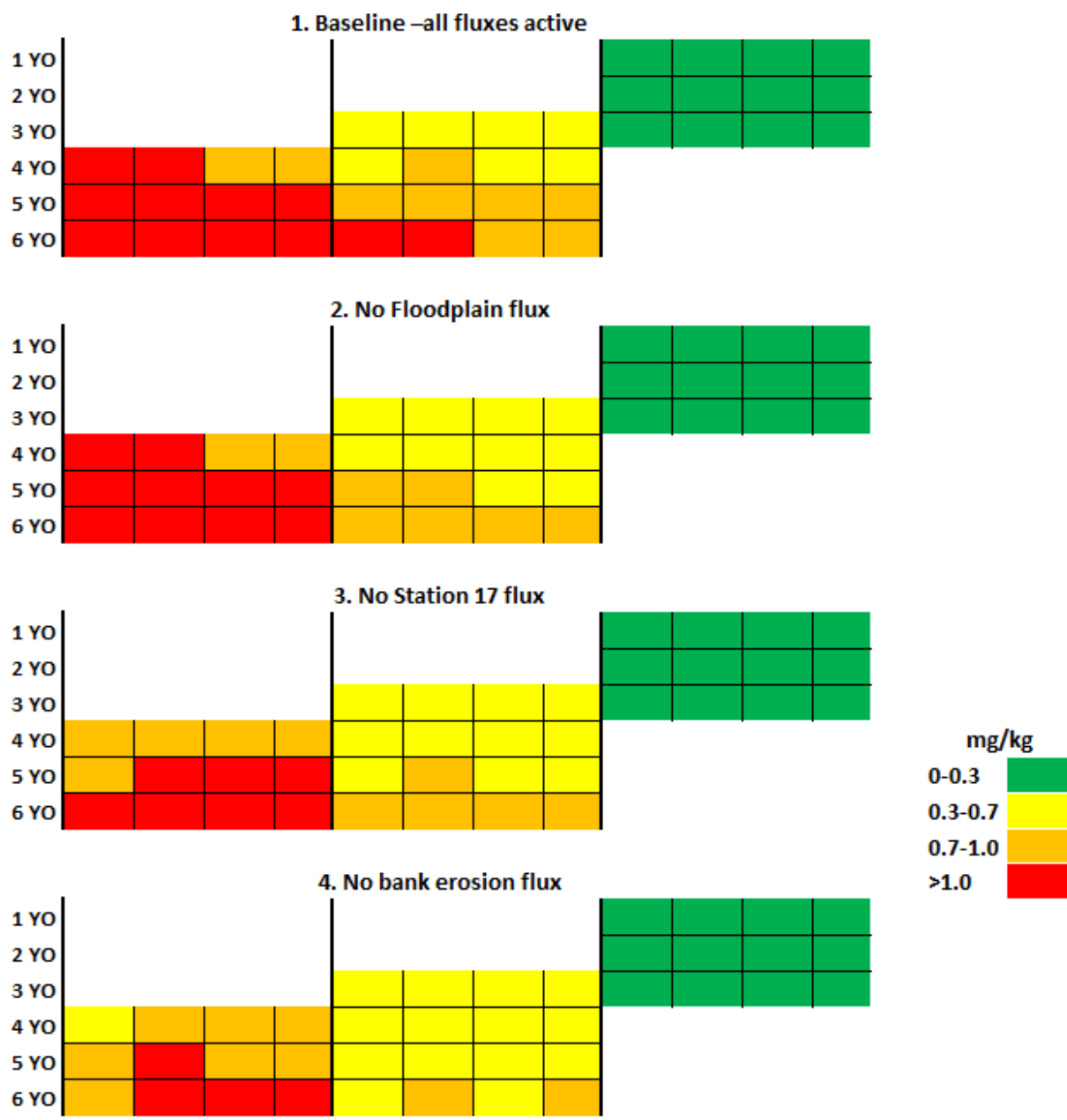

$>1.0$
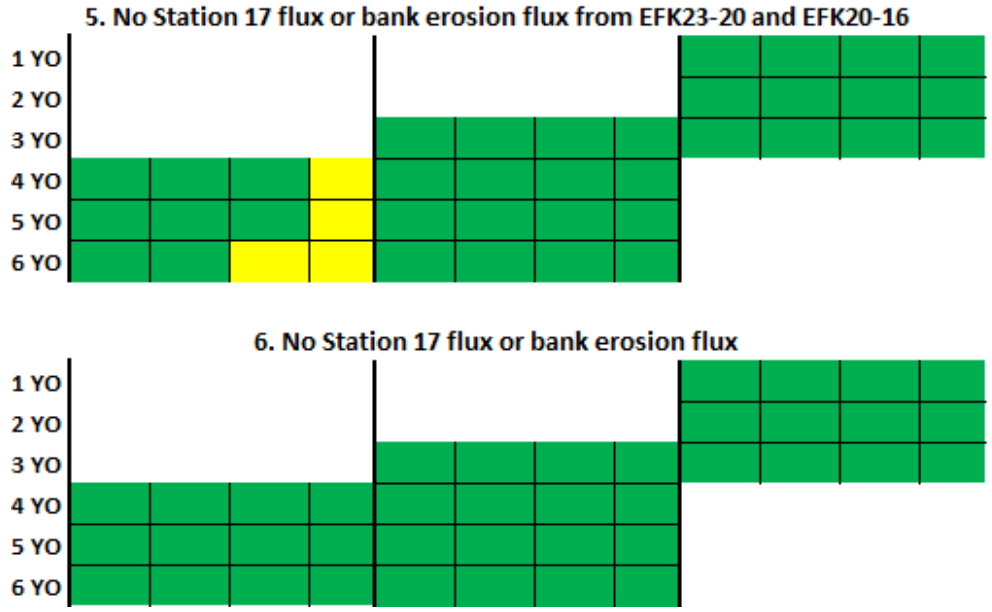

Fig. 79. Predicted approximate methylmercury (MeHg) concentrations in fish for each source reduction scenario. (Note: $\mathrm{EFK}=$ East Fork Poplar Creek kilometer; $\mathrm{YO}=$ year-old.) 



Fig. 80. Model simulated methylmercury (MeHg) concentrations in 5-year-old rock bass and sunfish, 3-year-old sunfish, and 2-year-old minnow at four stream reaches under no management action and five possible source reduction scenarios using periphyton $\mathrm{MeHg}$ concentrations derived from the watershed model.(Notes: EFK = East Fork Poplar Creek kilometer; ST17 = Station 17.) 


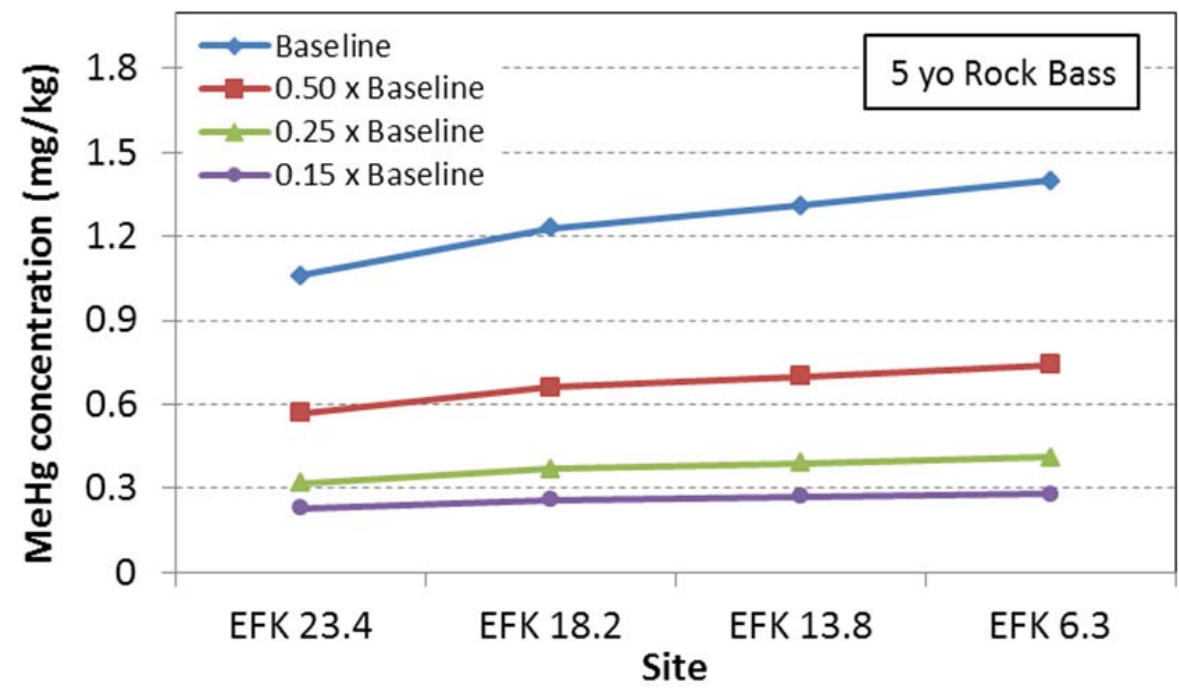

Fig. 81. Model simulated methylmercury (MeHg) concentrations in 5-year-old rock bass at baseline periphyton concentrations and at reduced periphyton concentrations at $0.5,0.25$, and 0.15 of baseline. (Note: $\mathrm{EFK}=$ East Fork Poplar Creek kilometer.)

\subsubsection{Key findings}

The purpose of most environmental modeling exercises is typically twofold: first, to understand processes, linkages, relationships, and behavior of the system of interest; and second, to be able to make predictions of possible outcomes when the system changes. The first occurs starting with model development and calibration and continues throughout the simulation and experimentation phase. The second, making predictions, is relatively easy to achieve, but the accuracy of the predictions is something that must be considered very carefully. Mercury dynamics in LEFPC are extremely complex. Through the modeling exercise described in this report, the research team gained great insight into the processes involved and into what is and is not known about the system and its complex relationships. However, the model (both watershed and biotic components) is based on a plethora of assumptions, and all numerical predictions should be viewed and used with caution and with an understanding that general insights produced by the model (e.g., that fish size effects may be more important than realized) are more informative than the absolute numbers.

With this background in mind, key findings from the bioaccumulation modeling include the following:

- Simulation of possible Hg flux reduction scenarios revealed that significant decreases in fish body burdens could be achieved if the major sources of mercury to the stream could be curtailed. The greatest reduction in fish mercury was associated with removal of mercury flux from Station 17 and bank soils.

- In general, the pattern of fish response in these simulations closely patterned the aqueous mercury responses, primarily because of the assumptions used in relating aqueous $\mathrm{MeHg}$ and periphyton.

- One goal of mercury uptake modeling was to assess which factors might explain the large amount of variability (within and among sites and within and among years) observed in $\mathrm{MeHg}$ concentrations in fish. A twofold difference in $\mathrm{MeHg}$ concentrations in piscivorous fish (i.e., top of the food web) between the upper and lower ends of EFPC is not uncommon. The research team found that reasonable variation in source concentrations, temperature, fish size and age, and diet could all contribute to the spatial and temporal variation observed, as follows: 
o It was found that observed differences in periphyton concentrations could explain about $25 \%$ of the variation.

o An increase in stream temperature from upstream to downstream could explain an increase in $\mathrm{MeHg}$ concentration of $6 \%$ per degree increase.

o Differences in the size or age of fish being analyzed for $\mathrm{MeHg}$ could result in $20 \%$ differences between fish that are only a year different in age.

o The model simulations demonstrate that $\mathrm{MeHg}$ concentrations in piscivorous fish (e.g., rock bass) are highly dependent on diet. Fish with a large portion of their diet composed of an insectivorous fish (e.g., sunfish) might assimilate twice the body burden $\mathrm{MeHg}$ as a counterpart whose diet consists mostly of invertebrates and primary consumers (e.g., minnows).

\subsection{FUTURE MODEL DEVELOPMENT}

Model conclusions are dependent on the data available at the time of this assessment when an understanding and quantification for many mercury-related parameters and relationships is still lacking. There is a continued need for field data collection and modeling improvements in the future. Model predictions described in this report should be viewed cautiously, with comparisons of the magnitude of predictions between scenarios being more valid than absolute predictions of concentrations or fluxes. The model framework, however, with continued updates and refinement, can be a useful and valuable tool for future EFPC research prioritization, technology development, and remedial decision-making. Following are some suggested next steps in model development that would significantly improve the model and its usefulness for decision-making.

Although there are uncertainties related to calculation of the $\mathrm{HgT}$ fluxes, it is not likely that the overall conclusion that bank erosion and Station 17 are the primary sources of mercury fluxes to the LEFPC watershed will change as more refined data are obtained. However, refinement in the estimates could be used to target specific areas for source reduction that would have the greatest impact. For example, a better understanding of the specific distribution of bank erosion fluxes and mapping of the highly contaminated HRD would help target bank erosion reductions.

To help refine flux estimates, it also would be helpful to have equivalent concurrent measurements of fluxes at Station 17 and EFK 5.4 and possibly at in-between locations. Currently, the concentrations and fluxes for EFK 5.4 that were used in the model are based on estimates of $\mathrm{Hg}$ and $\mathrm{MeHg}$ concentrations from regression equations and flow records and were not measured concurrently with Station 17 . There also is very little $\mathrm{MeHg}$ data related to storm sampling at Station 17 that can be used to estimate the impacts of storms on $\mathrm{MeHg}$ concentrations and fluxes at Station 17.

Conceptualizations of the primary instream pathways and processes for IHg and $\mathrm{MeHg}$ are shown in Figs. 82 and 83, respectively. The thickness and color of the arrows on these figures provide an indication of the estimated potential magnitude and importance of the processes. However, many of these processes, especially for $\mathrm{MeHg}$, are not well understood. Therefore, as new information is obtained and understanding of these processes improves or additional processes are identified, these figures will need to be updated along with the conceptual and numerical models. Processes and pathways with the highest uncertainty are represented in Figs. 82 and 83 using dashed arrows. IHg and MeHg concentrations and fluxes are dominated by very different sources and instream processes and pathways. Sources for $\mathrm{IHg}$ fluxes are mostly external, originating primarily from bank erosion and inflow from Station 17 . IHg instream processes/pathways are generally controlled by physical processes such as deposition and remobilization of suspended solids and sediment associated with variable flow conditions as well as by chemical processes like adsorption, desorption, and transformations (Fig. 82). Although under base flow 
conditions a high percentage of IHg can be in the dissolved form near Station 17, the IHg becomes increasingly associated with particulate matter in sediment and suspended solids further downstream and during stormflow conditions. There is uncertainty (1) in the chemical conditions at Y-12 that create such a high percentage of dissolved IHg in the upper reaches of EFPC and (2) if these conditions will change in the future and in turn affect $\mathrm{Hg}$ methylation and other processes. Therefore, more explicit inclusion of water chemistry impacts should be considered in future modeling efforts.

External inputs of $\mathrm{MeHg}$ to EFPC are relatively small (Fig. 83) compared with the large amount of $\mathrm{MeHg}$ that is generated from the in-stream transformation of $\mathrm{IHg}$ associated with biological activity (e.g., periphyton and sulfur reducing bacteria). There is considerable uncertainty in the current understanding of the mechanisms and rates of instream methylation and accumulation of $\mathrm{MeHg}$ on periphyton, detritus, sediments, and other stream media. There was also an underestimation of the total estimated $\mathrm{MeHg}$ fluxes for EFK 5.4 related primarily to the MeHg fluxes associated with suspended solids generated during stormflow events that can be explored to determine if the extra $\mathrm{MeHg}$ production may be related to undefined $\mathrm{MeHg}$ production (e.g., flow and methylation in undefined hyporheic zones), cyclical scouring and washing away of periphyton during storm events with regrowth of periphyton after the storm, or potential transference of the $\mathrm{MeHg}$ in periphyton to sediment and the water column through biological activity.

For the assessments included in this report, bedload transport of $\mathrm{IHg}$ and $\mathrm{MeHg}$ was assumed to be small relative to the fluxes of suspended and dissolved solids. However, the bedload in EFPC has not been quantified or modeled. Therefore, it is recommended that future modeling efforts include consideration of bedload transport.

The bioaccumulation model includes parameters and relationships that are incomplete or that need more data to decrease uncertainty. Learning the following information about the system would improve the model:

- A better understanding of methylation rates by periphyton and invertebrates

- Factors that affect $\mathrm{MeHg}$ assimilation rates by fish from consumed food

- An understanding of whether demethylation or depuration of MeHg occurs in fish and, if so, at what rates

- Importance of uptake and possible conversion of inorganic mercury to mercury concentrations in fish

- Better diet information from LEFPC predators

It is also important that the bioenergetics portion of the model be backed with more empirical data. Accurate food consumption rates and conversion efficiency are critical to achieving accurate $\mathrm{MeHg}$ assimilation rates. A modeling approach that makes these parameters more energetic-based instead of mass-based (i.e., based on caloric content instead of weight) could be of value. The model presently includes avenues for uptake of inorganic mercury through food and water and for uptake of $\mathrm{MeHg}$ through water, but these pathways are turned off until the rates and relationships are understood better.

Finally, model calibration was achieved based on average concentrations from fish collected over several years from LEFPC. Because of body burden data on individual fish of known length and weight, researchers can perform a more sophisticated calibration that produces a best fit by simultaneously considering many individuals of different sizes and from different sites instead of calibrating to an average fish that masks many of the important factors. Ultimately, converting model estimates of individual fish $\mathrm{MeHg}$ concentrations to population-level concentrations would provide the necessary information to estimate mass flux within the fish community relative to flux within the entire creek system. 
Size of arrow indicates magnitude of pathway flux

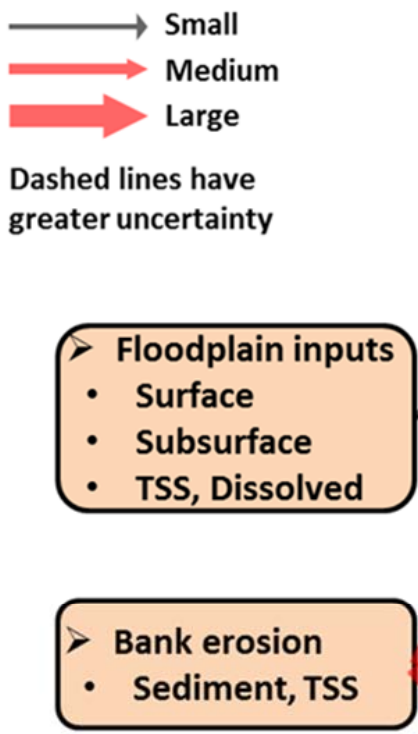

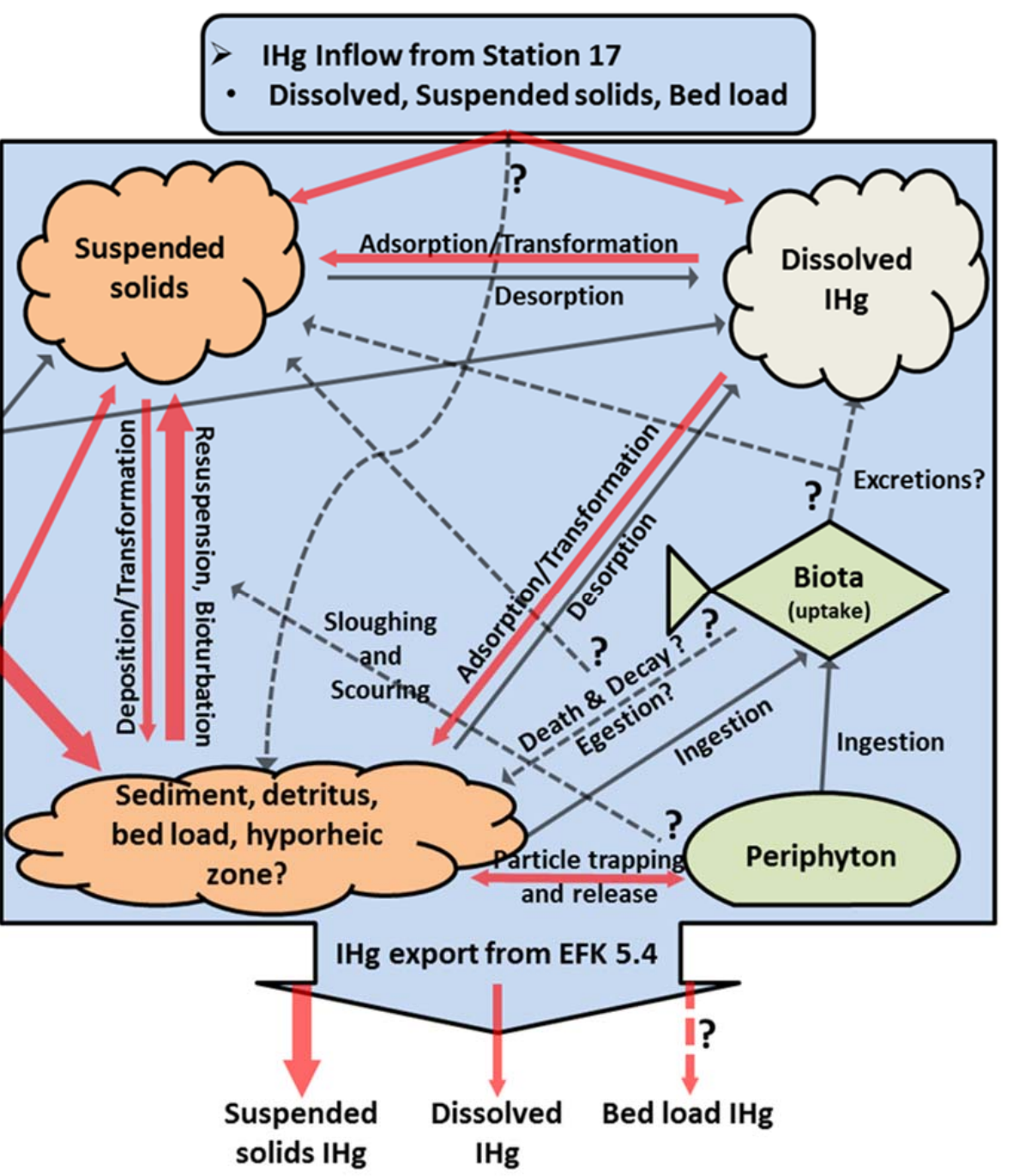

Fig. 82. Primary instream inorganic mercury (IHg) pathways.

(Notes: TSS = total suspended solids; EFK = East Fork Poplar Creek kilometer.) 


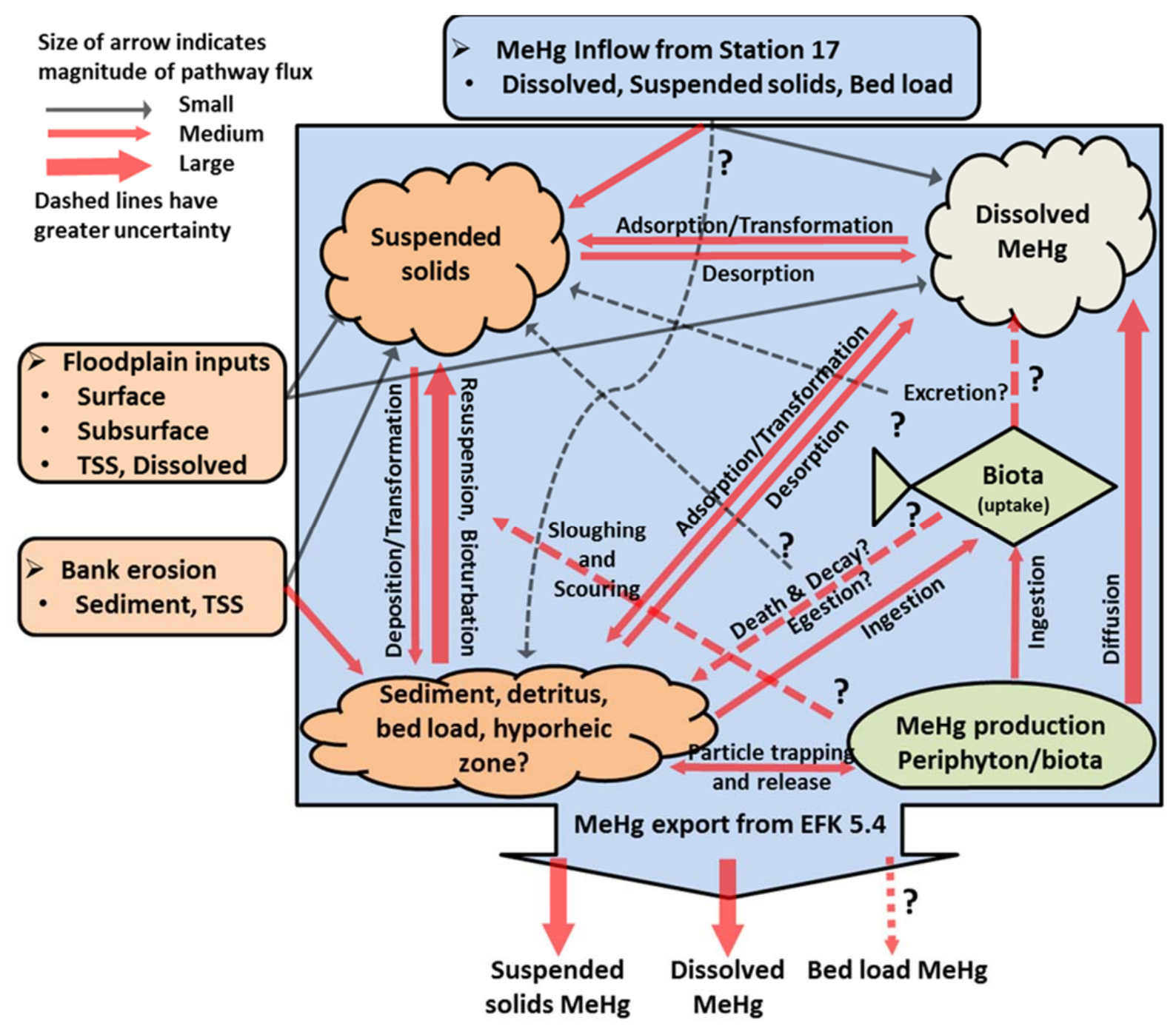

Fig. 83. Primary instream methylmercury (MeHg) pathways.

(Notes: TSS $=$ total suspended solids; EFK = East Fork Poplar Creek kilometer.) 



\section{CONCLUSIONS}

The research results presented in this report address the primary project goals of Action Plan 1, to evaluate the role of LEFPC bank soil sources and to consider the entire EFPC hydrologic system. It is the culmination of a multiyear effort that used direct field and laboratory study coupled with monitoring and research data from multiple programs to develop a watershed-scale model of mercury flux. The research is especially noteworthy for its innovative approach to better understanding the role of stream bank sources on the hydrologic system, using kayak surveys to evaluate erosion coupled with detailed bank soil analyses of mercury. The model incorporates an unprecedented level of data and research from EFPC and is the most comprehensive watershed-scale evaluation of the sources of mercury in EFPC to date.

Based on field research and modeling conducted for this project, the most significant research conclusions are the following:

- Several lines of evidence indicate that floodplain surface soils contribute a very minor fraction of mercury into LEFPC.

- The greatest flux of HgT in LEFPC is related to the mostly stormflow-driven bank erosion in the upper reaches.

- The second greatest flux originates from Station 17 and appears to control base flow fluxes.

- A meaningful substantial reduction of the HgT flux, methylation, and bioaccumulation in LEFPC would require addressing the flux of $\mathrm{HgT}$ originating from both Station 17 and bank erosion.

Although this research provides a significant step forward in the understanding of mercury processes in EFPC, there are many areas of uncertainty. The model uses the best available data through early 2015 and should be updated and revised as new data and knowledge are available.

Conceptual and quantitative models are essential platforms for integrating complex data and processes. Here the modeling effort was deemed especially well-suited to the goal of obtaining a more holistic, watershed-scale understanding of mercury processes in EFPC. The model incorporates the current understanding of relative flux, concentration, transformation, and bioaccumulation of $\mathrm{IHg}$ and $\mathrm{MeHg}$ into a framework designed to identify the primary sources and drivers for elevated mercury levels. Ultimately, as more data are collected in the coming years, it is anticipated that the watershed-scale modeling approach will be extremely valuable to future EM decision-making, especially relative to the prioritization of potential cleanup alternatives in LEFPC. 



\section{REFERENCES}

Acha, D., H. Hintelmann, and J. Yee. 2011. "Importance of Sulfate Reducing Bacteria in Mercury Methylation and Demethylation in Periphyton from Bolivian Amazon Region." Chemosphere 82 (6):911-916. doi: 10.1016/j.chemosphere.2010.10.050.

Bell, A. H., and B. C. Scudder. 2007. "Mercury Accumulation in Periphyton of Eight River Ecosystems." Journal of the American Water Resource Association 43 (4):957-968. doi: 10.1111/j.17521688.2007.00078.x.

Cleckner, L. B., et al. 1999. "Mercury Methylation in Periphyton of the Florida Everglades." Limnology Oceanography 44 (7):1815-1825. doi: 10.4319/lo.1999.44.7.1815.

Correia, R. R. S., M. R. Miranda, and J. R. D. Guimaraes. 2012. "Mercury methylation and the microbial consortium in periphyton of tropical macrophytes: Effect of different inhibitors." Environmental Research 112:86-91. Published online November 23, 2011.

Desrosiers, M., D. Planas, and A. Mucci. 2006. "Mercury Methylation in the Epilithon of Boreal Shield Aquatic Ecosystems." Environmental Science \& Technology 40 (5):1540-1546. doi: $10.1021 / \mathrm{es} 0508828$.

Dickson, J. O., et al. 2015. Soil Investigation of Lower East Fork Poplar Creek. ORNL-TM/2015-374, Oak Ridge National Laboratory, Oak Ridge TN.

Doll, B. A., et al. 2003. "Hydraulic Geometry Relationships for Rural North Carolina Coastal Plain Streams." In Report to NC Division of Water Quality. NC Stream Restoration Institute, 39:11. http://www.bae.ncsu.edu/programs/extension/wqg/srp/techresources.html.

Guillard, R. L. 1975. "Culture of Phytoplankton for Feeding Marine Invertebrates." In Culture of Marine Invertebrate Animals, edited by W. S. a. M. Chanley. Springer US:29-60.

Hamelin, S., D. Planas, and M. Amyot. 2015. "Mercury methylation and demethylation by periphyton biofilms and their host in a fluvial wetland of the St. Lawrence River (QC, Canada)." Science of The Total Environment 512-513:464-471. Published online January 30, 2015.

Huguet, L., et al. 2010. "Mercury Methylation Rates of Biofilm and Plankton Microorganisms from a Hydroelectric Reservoir in French Guiana." Science of The Total Environment 408 (6):13381348. doi: 10.1016/j.scitotenv.2009.10.058.

Lutz, B. D., P. J. Mulholland, and E. S. Bernhardt. 2012. "Long-Term Data Reveal Patterns and Controls on Stream Water Chemistry in a Forested Stream: Walker Branch, Tennessee.” Ecological Monographs 82 (3):367-387.

Mathews, T., et al. 2013. "Decreasing Aqueous Mercury Concentrations to Achieve Safe Levels in Fish: Examining the Water-Fish Relationship in Two Point-Source Contaminated Streams." Science of the Total Environment 443:836-843.

Olsen, T., and S. C. Brooks. "Mercury Fate and Biogeochemistry Session." Presentation at Society of Environmental Toxicology and Chemistry (SETAC) North America 36th Annual Meeting, Salt Lake City, Utah, November 2015.

Peterson, M. J., et al. 2015. Mercury Remediation Technology Development for Lower East Fork Poplar Creek. ORNL/SPR-2014/645, Oak Ridge National Laboratory, Oak Ridge, TN.

Riscassi, A. L., C. Miller, and S. Brooks. 2015. "Seasonal and Flow-Driven Dynamics of Particulate and Dissolved Mercury and Methylmercury in a Stream Impacted by an Industrial Mercury Source." Environmental Toxicology and Chemistry. doi: 10.1002/etc.3310. Published online Nov. 17, 2015.

Shiao, M., and J. Peryam. 2009. "Mercury Dynamics in East Fork Poplar Creek." Powerpoint presentation.

Shiao, M., and J. Peryam. Undated. "Impacts of Oak Ridge Sewage Discharge on Downstream Mercury Methylation.” Powerpoint presentation. 
Southworth, G., et al. 2013. "Sources of Mercury in a Contaminated Stream-Implications for the Timescale of Recovery.” Environmental Toxicology and Chemistry 32 (4):764-772. doi: 10.1002/etc.2115.

Southworth, G., et al. 2012. Steady-State Model of Mercury Transport, Methylation, and Bioaccumulation in East Fork Poplar Creek. ORNL/TM-2012/354, Oak Ridge National Laboratory, Oak Ridge, TN.

Southworth, G. R., et al. 2010. Sources of Mercury to East Fork Poplar Creek Downstream from the Y-12 National Security Complex: Inventories and Export Rates. ORNL/TM-2009/231, Oak Ridge National Laboratory, Oak Ridge, TN.

Southworth, G. R., et al. 2011. "Monitoring Fish Contaminant Responses to Abatement Actions: Factors that Affect Recovery." Environmental Management 47:1064-1076.

UCOR. 2014. 2014 Remediation Effectiveness Report for the U.S. Department of Energy Oak Ridge Reservation, Oak Ridge, Tennessee Data and Evaluations. DOE/OR/01-2640\&D2, Water Resources Restoration Program, URS-CH2M Oak Ridge.

US Geological Survey. 1990. Recharge Rates and Aquifer Hydraulic Characteristics for Selected Drainage Basins in Middle and East Tennessee. Water-Resources Investigations Report 90-4015, US Geological Survey, Tennessee State Planning Office, and Tennessee Department of Health and Environment, Nashville, TN.

Wilson, K. B., et al. 2001. "A Comparison of Methods for Determining Forest Evapotranspiration and Its Components: Sap-Flow, Soil Water Budget, Eddy Covariance and Catchment Water Balance." Agricultural and Forest Meteorology 106:153-168. 


\section{APPENDIX A. SUPPLEMENTAL DATA SUMMARY}

This appendix provides a summary of the supplemental data files available for the project, including metadata and data referenced in the report. These data will be made available by request to the Oak Ridge Environmental Information System (OREIS [http: ||www.ucor.com\oreis.html]).

\section{PARENT DIRECTORY}

The supplemental data for this report is organized into subfolders based on the order each dataset is referenced in the report. Supplemental data includes information on kayak surveys, bank soil assessment, groundwater assessment, and modeling outputs.

\section{IIsupplementalData}

parent directory for supplemental data

\section{\README!.docx}

this document, which provides metadata for supplemental data

\section{EFPC KAYAK SURVEYS}

Dr. Paul Ayers of the Biosystems Engineering and Soil Science Department at the University of Tennessee was contracted to obtain georeferenced video of the LEFPC stream bank and substrate. The work included 1) conducting a stream survey to acquire georeferenced video images and physical measurements of stream bank and creek conditions, 2) development of GIS maps of the stream bank condition and areas of high erosion potential, and 3) estimation of total daily sediment loads using the survey data. A GPS-based, kayak-mounted above-water and underwater video mapping and electronic sensor system was used to survey stream bank and erosion conditions and canopy light penetration on EFPC. Dr. Ayers and his team conducted two initial surveys on the lower $23 \mathrm{~km}$ of EFPC during leaf-off and leaf-on conditions in March and July 2013. A third survey in August 2013 collected information along the section of EFPC from Outfall 200 to EFK 23, thereby overlapping slightly with the upper end of the previous surveys. Stream and bank attributes were acquired from interpretation of the recorded video and kayak sensor measurements. Results are summarized in report section 3.1.1. The structure of the data supplement subfolder for the kayak survey assessment is as follows:

\section{$\underline{\text { la1 kayakData }}$}

folder that contains kayak data described in report section 3.1

\section{lkayakDataCollection_finalReport.docx}

summary report of kayak data collection effort

\section{kayakDataAttributes.docx}

description of attributes included in GIS shapefiles

\section{$\underline{\underline{Y Y 12}}$}

GIS shapefiles for kayak data collected in sections $(n=2)$ of EFPC within Y12 complex

\section{$\underline{\text { LEFPC }}$}

GIS shapefiles for kayak data collected in sections $(n=3)$ of EFPC downstream of Y12 complex 


\section{BANK SOIL EROSION AND MERCURY DATA}

Erosion pins are a widely used method to make point estimates of erosion or deposition. The method consists of driving a narrow diameter metal rod into the stream bank so it is flush with the surface. To quantify erosion, the length of exposed pin is measured using a washer placed over the pin and against the soil surface to give a base from which to measure. Deposition is measured similarly after carefully exposing the tip of the pin after burial. Eight erosion pin sets were installed at seven sites along the creek in November 2013. Two to three erosion pins were installed at each site along a vertical stream bank transect extending from near the water's edge to near the top of the stream bank. Erosion/deposition was measured over the course of a 531-day erosion pin deployment. The total net erosion or deposition measured at each pin was divided by the duration of deployment to calculate bank erosion rate based on these field measurements. In conjunction with the erosion pin work, samples of bank soil were collected and analyzed for total mercury content. Bank samples were collected at the same vertical elevation as erosion pins but some distance away to avoid inducing erosion artifacts. Results are summarized in report section 3.1.1. The structure of the data supplement subfolder for the bank soils assessment is as follows:

\section{la2 bankSoilsData}

folder that contains bank soil erosion, deposition, and mercury sampling results described in report section 3.1

\section{lerosionDeposition.docx}

data table of measured erosion (-) and deposition $(+)$ for erosion pins deployed along banks of EFPC

\section{\hgInSoilCores.docx}

data table of total mercury $(\mathrm{Hg})$ concentrations in horizontal cores of creek bank soils

\section{GROUNDWATER DATA}

On July 2, 2013, several shallow piezometers were installed in the floodplain adjacent to the creek to assess the role shallow groundwater may play in mercury cycling and dynamics in the creek. Groundwater from these wells was sampled and analyzed for a suite of constituents including field parameters and laboratory measurements. Results of the groundwater analyses were compared with results for creek surface water collected at the same time. Results are summarized in report section 3.1.2. The structure of the data supplement subfolder for the groundwater assessment is as follows:

\section{$\underline{\text { la3 groundwaterData }}$}

folder that contains well construction diagrams and groundwater data, as described in report section 3.1.2

\section{IwellConstructionData.docx}

well construction diagrams and installation information for monitoring wells MBFP01, MBFP02, MBFP03, MBFP04

\section{groundwaterData.xlsx}

spreadsheet of groundwater analytical data that includes descriptions of table field names, details on sample collection, results, and QA/QC information

\section{MODELING DATA}

A multi-compartment approach was taken to develop a generalized conceptual model for the EFPC watershed. Compartment-based conceptual models provided the foundation for development of a 
quantitative watershed modeling effort. In the physical-chemical watershed model, total $\mathrm{Hg}$ and $\mathrm{MeHg}$ dynamics are assessed by examining upstream inputs, floodplain runoff, floodplain leaching, bank soil erosion, and periphyton matrix dynamics. The physical-chemical watershed model was designed to interact with a bioaccumulation model that predicts $\mathrm{MeHg}$ uptake into fish. The bioaccumulation model tracks the feeding, growth, and $\mathrm{MeHg}$ assimilation of representative individual fish-from three species that represent three different trophic levels - through their typical life span using fish size, water temperature, and diet as key inputs. BMAP bioaccumulation and fish community data from EFPC was an important source of data for calibration (and can be obtained by conventional queries in OREIS). Model runs were conducted to evaluate the impact of changing various mercury input fluxes that could be representative of six different hypothetical source reductions on $\mathrm{HgT}$ and $\mathrm{MeHg}$ concentrations and fluxes for the watershed and within individual stream reaches. Results are summarized in report sections 4.1.2 and 4.2.2. The structure of the data supplement subfolder for the modeling outputs is as follows:

\section{$\underline{\text { la4_modelOutputs }}$}

folder that contains predictions from the physical-chemical and bioaccumulation models described in Chapter 4 of report

\section{IphysicalChemicalModelOutputs.xlsx}

model predictions of average monthly fluxes and concentrations in surface water and periphyton of $\mathrm{IHg}$ and $\mathrm{MeHg}$ for each of the six source reduction scenarios

\section{bioaccumulationModelOutputs.xlsx}

model predictions of average annual concentrations of $\mathrm{MeHg}$ in rock bass, redbreast sunfish, and stoneroller minnows for each of the six source reduction scenarios 
